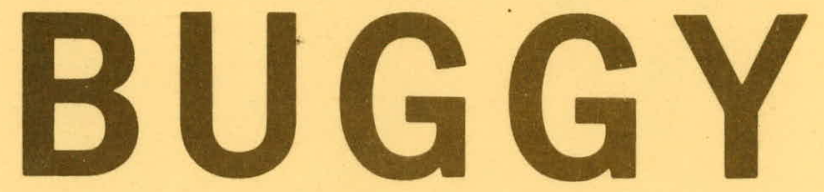

PHOTOGRAPHIC AND ACCELEROMETER

MEASUREMENTS OF THE SURFACE

MOTION ON THE BUGGY

CRATERING EXPERIMENT

Issuance Date: February 12, 1970

THIS DOCUMENT CONFIRMED AS UNCLASSIFIED

DIVISION OF CLASSIFICATION

BY

DATE Q.H.kahm

Lawrence Radiation Laboratory

Livermore, California
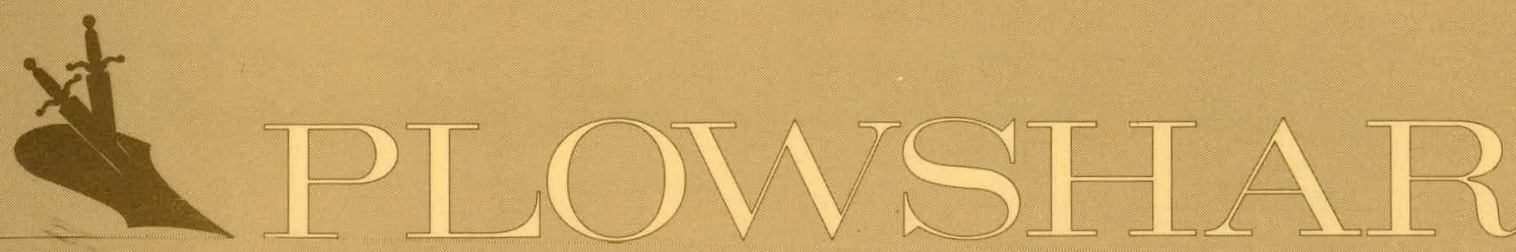

UNITED STATES ATOMIC ENERGY COMMISSION CIVIL, INDUSTRIAL AND SCIENTIFIC USES FOR NUCLEAR EXPLOSIVES 


\section{DISCLAIMER}

This report was prepared as an account of work sponsored by an agency of the United States Government. Neither the United States Government nor any agency Thereof, nor any of their employees, makes any warranty, express or implied, or assumes any legal liability or responsibility for the accuracy, completeness, or usefulness of any information, apparatus, product, or process disclosed, or represents that its use would not infringe privately owned rights. Reference herein to any specific commercial product, process, or service by trade name, trademark, manufacturer, or otherwise does not necessarily constitute or imply its endorsement, recommendation, or favoring by the United States Government or any agency thereof. The views and opinions of authors expressed herein do not necessarily state or reflect those of the United States Government or any agency thereof. 


\section{DISCLAIMER}

Portions of this document may be illegible in electronic image products. Images are produced from the best available original document. 


\section{LEGAL NOTICE}

This report was prepared as an account of Government sponsored work. Neither the United States, nor the Commission, nor any person acting on behalf of the Commission:

A. Makes any warranty or representation, expressed or implied, with respect to the accuracy, completeness, or usefulness of the information contained in this report, or that the use of any information, apparatus, method, or process disclosed in this report may not infringe privately owned rights; or

B. Assumes any liabilities with respect to the use of, or for damages resulting from the use of any information, apparatus, method, or process disclosed in this report.

As used in the above, "person acting on behalf of the Commission" includes any employee or contractor of the Commission, or employee of such contractor, to the extent that such employee or contractor of the Commission, or employee of such contractor prepares, disseminates, or provides access to, any information pursuant to his employment or contract with the Commission, or his employment with such contractor.

This report has been reproduced directly from the best available copy.

Printed in USA. Price $\$ 3.00$. Available from the Clearinghouse for Federal Scientific and Technical Information, National Bureau of Standards, U. S. Department of Commerce, Springfield, Virginia 22151. 
PNE-325

\section{MASTER}

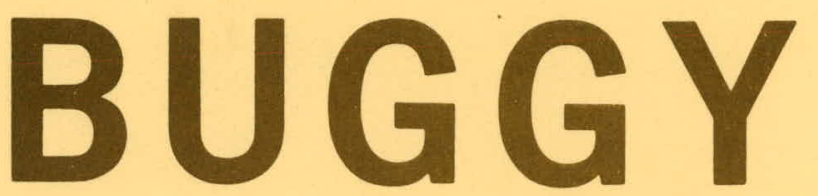

\section{PHOTOGRAPHIC AND ACCELEROMETER \\ MEASUREMENTS OF THE SURFACE \\ MOTION ON THE BUGGY \\ CRATERING EXPERIMENT}

Issuance Date: February 12, 1970

Lawrence Radiation Laboratory

Livermore, California
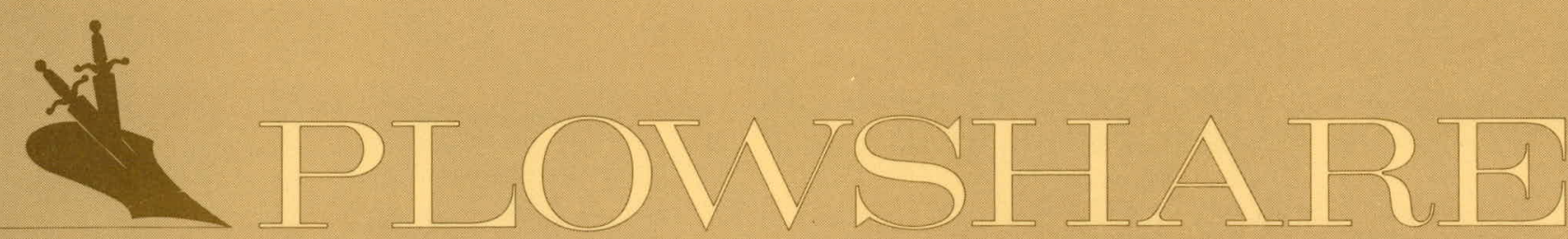

UNITED STATES ATOMIC ENERGY COMMISSION CIVIL, INDUSTRIAL AND SCIENTIFIC USES FOR NUCLEAR EXPLOSIVES 


\section{LEGAL NOTICE}

This report was prepared as an account of Government sponsored work. Neither the United States, nor the Commission, nor any person acting on behalf of the Commission:

A. Makes any warranty or representation, expressed or implied, with respect to the accuracy, completeness, or uscfulness of the information contained in this report, or that the use of any information, apparatus, method, or process disclosed in this report may not infringe privately owned rights; or

B. Assumes any liabilities with respect to the use of, or for damages resulting from the use of any information, apparatus, method, or process disclosed in this report.

As used in the above, "person acting on behalf of the Commission" includes any employee or contractor of the Commission, or employee of such contractor, to the extent that such employee or contractor of the Commission, or employee of such contractor prepares, disseminates, or provides access to, any information pursuant to his employment or contract with the Commission, or his employment with such contractor.

This report has been reproduced directly from the best available copy.

Printed in USA. Price $\$ 3.00$. Available from the Clearinghouse for Federal Scientific and Technical Information, National Bureau of Standards, U. S. Department of Commerce, Springfield, Virginia 22151. 
PNE- 325

NUCLEAR EXPLOSIONS - PEACEFUL

\section{PHOTOGRAPHIC AND ACCELEROMETER MEASUREMENTS OF THE SURFACE MOTION ON THE BUGGY CRATERING EXPERIMENT}

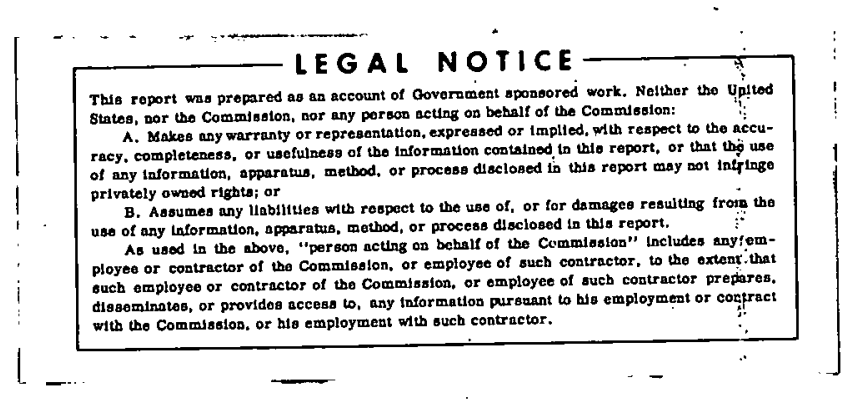

Robert F. Rohrer William R. Hurdlow

Lawrence Radiation Laboratory Livermore, California.

August 1969 DISTRIBUTION OF THIS DOCUMENT IS UNLIMITED. 


\section{Acknowledgments}

The assistance of the following individuals is gratefully acknowledged. Dale Wilson and his associates of EG\&G performed the field photography. A number of people from LRL contributed. Michael Milochik processed the field film and made prints for the Eyeball computer program. Robert Malone and Robert Terhune assisted with the computer processing of the surface motion data. Clyde Sisemore did the preliminary scientific design of the accelerometer array. Don Ruffner did the mechanical design of the new flare targets, falling mass targets, and accelerometer installation. Ray Stefani was responsible for electronic recording and playback of the accelerometer signals. 


\begin{abstract}
Surface motion data as a function of time are presented for the Buggy cratering experiment, in which five nuclear charges in a line were fired simultaneously. The surface motion was measured photographically and with accelerometers. In the photographic measurements, highspeed motion picture cameras followed the motion of arrays of ground target flares over the cratering zone and of two falling mass experiments located near two of the emplacement holes. The results presented consist of graphs of displacement, velocity, and acceleration as functions of time. Observed velocities of the mount are compared with calculated predictions.
\end{abstract}




\section{Contents}

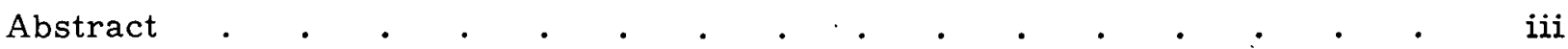

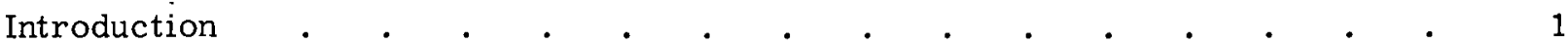

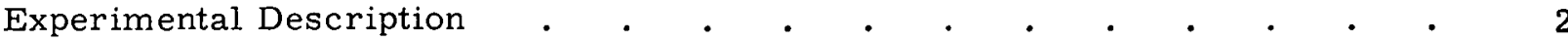

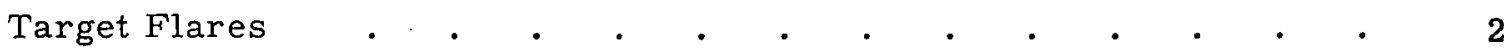

Falling Mass Experiments $\quad$. $\quad . \quad$. $\quad . \quad$. . . . . 5

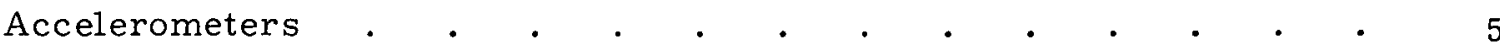

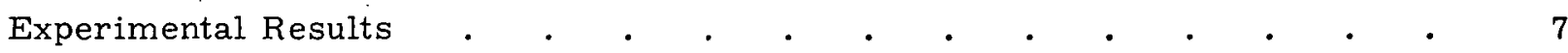

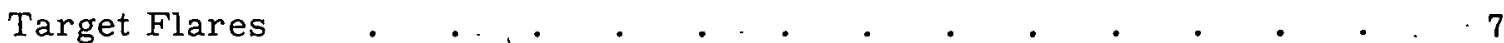

Falling Mass Experiments $\quad . \quad$. . . . . . . . . . . 10

Accelerometers .

Discussion of Results $\quad . \quad$.

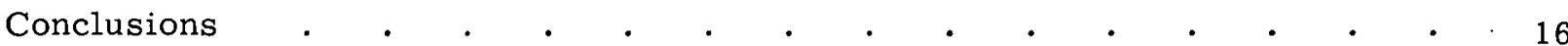

Appendix: Sources of Error, Smoothing Parameters, Data Plots $\quad$ • . . . 17

\section{Tables and Figures}

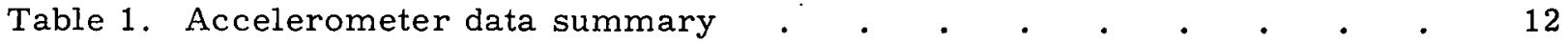

Table 2. Selected results of measured surface motion $\quad . \quad$. . . . 15

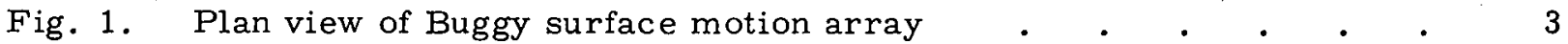

Fig. 2. View of Buggy array from near hole A . . . . . . . . . . . 44

Fig. 3. Typical accelerometer installation . . . . . . . . . . . 6

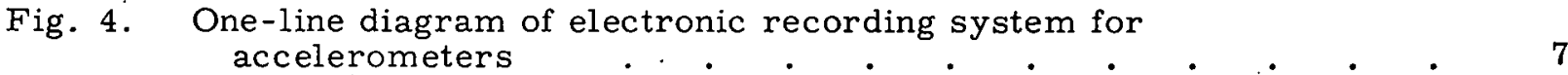

Fig. 5. Vertical displacements of targets along axis of charges
at various times

Fig. 6. Vertical velocities of targets along axis of charges . . . . . . 8

Fig. 7. Vertical displacements along the cross arrays . . . . . . 9

Fig. 8. Vertical velocities along the cross arrays . . . . . . . . . 9

Fig. 9. Vertical displacement of falling mass target at hole $\mathrm{C}$. . . $\quad 10$

Fig. 10. Vertical velocity of falling mass target at hole C _ . . . . . 11

Fig. 11. Vertical velocity of falling mass target at hole A $\quad$. . . . . 11

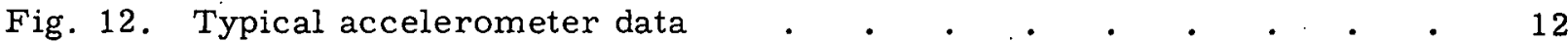

Fig. 13. Enhancement of peak vertical velocity by charge

Fig. 14. Topographic profiles of the Buggy crater . . . . . . . . 14 


\section{Figures in Appendix}

A-1 through A-48. Vertical displacements of targets along axis of charges

A-49 through A-65. Horizontal displacements of targets along axis of charges

A-66 through A-72. Vertical displacements of targets along the two cross arrays

A-73 througn A-79.

Vertical velocities of targets along the two cross arrays.

A-80 through A-95. Vertical velocities of targets along axis of charges

A-96 through A-110. Surface acceleration from accelerometers A-1 through A-15 


\title{
PHOTOGRAPHIC AND ACCELEROMETER MEASUREMENTS OF THE SURFACE MOTION ON THE BUGGY CRATERING EXPERIMENT
}

\author{
Introduction
}

Project Buggy was the first nuclearrow cratering detonation executed as part of the Plowshare Program for development of nuclear excavation techniques. Five nuclear explosives, each with a yield of $1.1 \mathrm{kt}$, were detonated simultaneously at 0904:00.111 PST, 12 March 1968. The depths of burst were at 135 feet, and the spacing between explosives was 150 feet. The experiment took place on Chukar Mesa, Area 30, Nevada Test Site, in a dry, complex basalt formation. Surface ground zero coordinates of the end emplacement holes designated as U-30-A and $\mathrm{U}-30-\mathrm{E}$ were:

\begin{tabular}{|c|c|c|}
\hline \multirow{3}{*}{$\begin{array}{l}\text { NTS Grid } \\
\text { Coordinates }\end{array}$} & $\mathrm{U}-30-\mathrm{A}$ & $\mathrm{U}-30-\mathrm{E}$ \\
\hline & N $821,828.24$ & N 822,039.76 \\
\hline & E 586,630.95 & E $586,069.54$ \\
\hline atitude & N $37^{\circ} 0^{\prime} 27^{\prime \prime}$ & $\mathrm{N} 37^{\circ} 0^{\prime} 29^{\prime \prime}$ \\
\hline Longitude & $\mathrm{W} 116^{\circ} 22^{\prime} 12^{\prime \prime}$ & $\mathrm{W} 116^{\circ} 22^{\prime} 19^{\prime \prime}$ \\
\hline
\end{tabular}

The line of charges was on a bearing of N $69^{\circ} 21^{\prime} 05^{\prime \prime} \mathrm{W}$. Ground elevations at each hole were as follows:

$\begin{array}{cc}\text { Hole } & \text { Elevation (MSL, ft) } \\ & 5208.28 \\ \text { B } & 5210.04 \\ \text { C } & 5210.52 \\ \text { D } & 5209.47 \\ \text { E } & 5208.42\end{array}$

The principal objectives of the experiment were to:
(1) Determine nuclear row parameters through level terrain in hard, dry rock;

(2) Determine the fraction of radioactivity which escapes the immediate cratered aŕea.

Apparent crater dimensions which describe the excavation are:

\begin{tabular}{|c|c|c|}
\hline & Feet & $\begin{array}{l}\text { Cubic } \\
\text { yds }\end{array}$ \\
\hline $\begin{array}{l}\text { Apparent crater width, } \\
\text { average }\left(W_{a}\right)\end{array}$ & 254 & \\
\hline $\begin{array}{l}\text { Apparent crater depth, } \\
\text { maximum }\left(D_{a}\right)\end{array}$ & 69.8 & \\
\hline $\begin{array}{l}\text { Lip crest width, } \\
\quad \text { average }\left(\mathrm{W}_{\mathrm{al}}\right)\end{array}$ & 355 & \\
\hline $\begin{array}{l}\text { Apparent crater length } \\
\left(\mathrm{L}_{\mathrm{a}}\right)\end{array}$ & 865 & \\
\hline $\begin{array}{l}\text { Apparent lip height, } \\
\text { average }\left(\mathrm{H}_{\mathrm{al}}\right) \text { sides }\end{array}$ & 41 & \\
\hline $\begin{array}{l}\text { Apparent lip height, } \\
\text { average }\left(\mathrm{H}_{\mathrm{al}}\right) \text { ends }\end{array}$ & 14 & \\
\hline Apparent crater volume & & 262,456 \\
\hline Apparent lip volume & & 422,205 \\
\hline
\end{tabular}

A number of cratering experiments have been conducted for several years at the Nevada Test Site and other locations. These experiments were done using high explosives and nuclear explosives. Several experiments had been done with row charges using high explosives, but none with nuclear explosives. -Therefore, Buggy was the first opportunity to measure surface motion on a 
multiple-nuclear-charge cratering experiment.

The cratering behavior of such an experiment is difficult to predict even if the basic physical and geological properties are known. To evaluate the results of early computer calculations and to improve, future ones, we measured the motion of the surface throughout the cratering area. There were two independent experiments for this purpose. High-speed motion pictures of target flares and two falling-mass experiments gave the surface displacement history, while the surface acceleration was measured with an array of accelerometers.

The surface motion experiments on Buggy had the following objectives:

1. To measure the velocities due to early spall and late gas acceleration over the individual charges of Buggy.

2 . To determine the surface velocities midway between the charges.

3 . To study the effect of the different geologic layering on the surface motion.

4. To determine the surface motions along two lines perpendicular to the line of charges, and to see what enhancement was produced in the surface velocities along these lines by the interaction of charges.

5. To establish, by comparison with theoretical calculations, the sophistication of the physical modeling needed for prediction.

6. To compare the velocity results obtained from the flares and falling masses with the accelerometer data.

\section{Experimental Description}

Figure 1 is a plan view of the Buggy site, showing the five emplacement holes and the stations where the surface motion observations were made. Three kinds of observations were included: photographs of target flares, photographs of a freefalling mass in relation to a ground target, and measurements with accelerometers. The observation stations were distributed over the area in such a way as to give a detailed picture of the surface motion during the early stages of cratering.

\section{TARGET FLARES}

An array of target flares was located in the Buggy ground zero area as shown in Fig. 1. Most of these targets were spaced along the line of emplacement holes, extending out $150 \mathrm{ft}$ beyond the end holes, but there were also two shorter lines of targets running out at right angles to the line of holes. The flare material for most of the targets was pyrogen rocket propellant. Only a few targets used the standard magnesium flare.

The target design was new for Buggy. The targets used previously on Cabriolet were heavy, with a triangular base and three triangular sides. The new target, shown in Fig. 2, is aluminum, attached to a cement pad which couples to the ground. Twenty-eight of these new targets were used for Buggy, together with three of the old triangular targets.

An array of four targets extended from hole $\mathrm{C}$ perpendicular to the line of charges as shown in Fig. 1, and another array of 


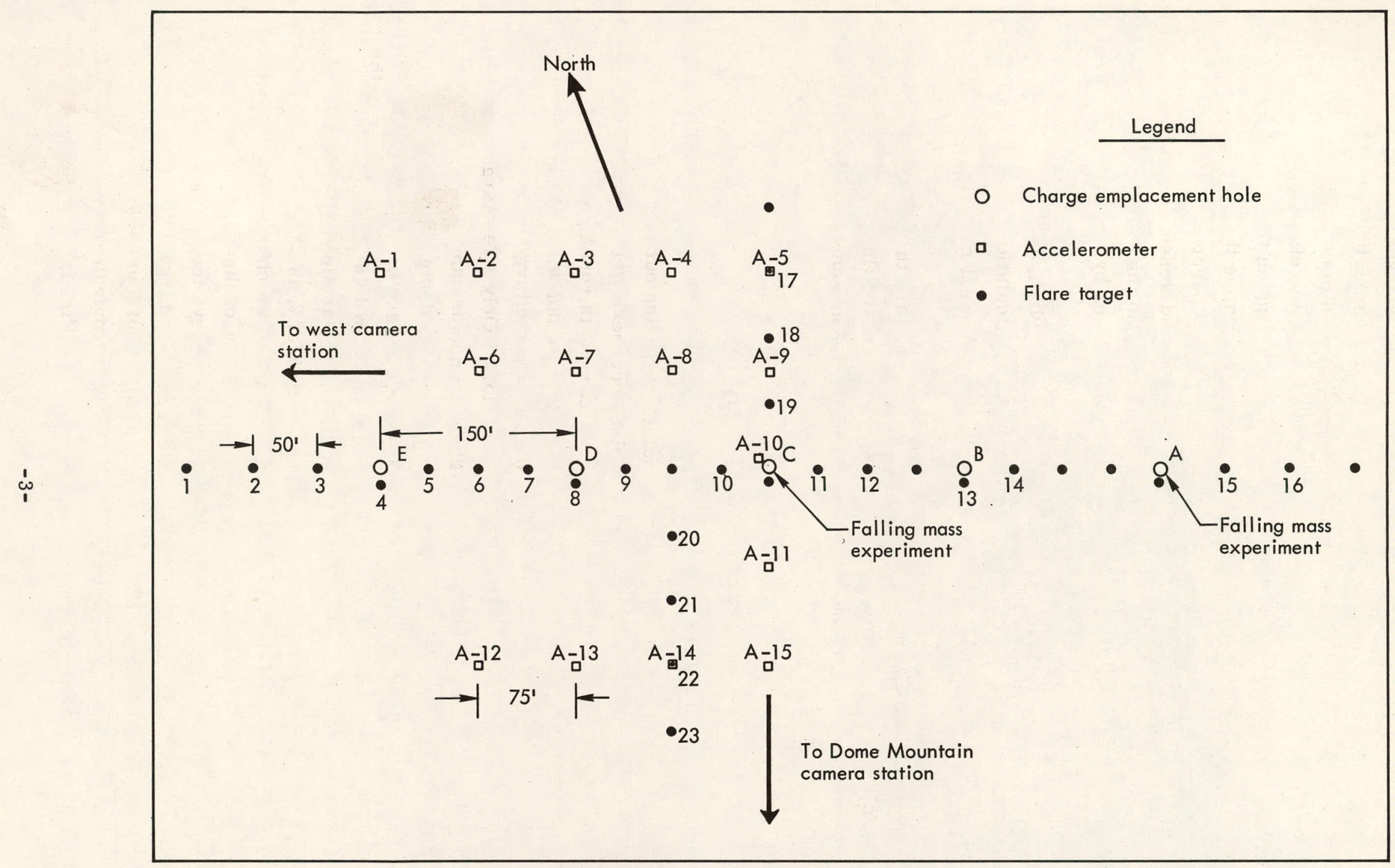

Fig. 1. Plan view of Buggy surface motion array. 


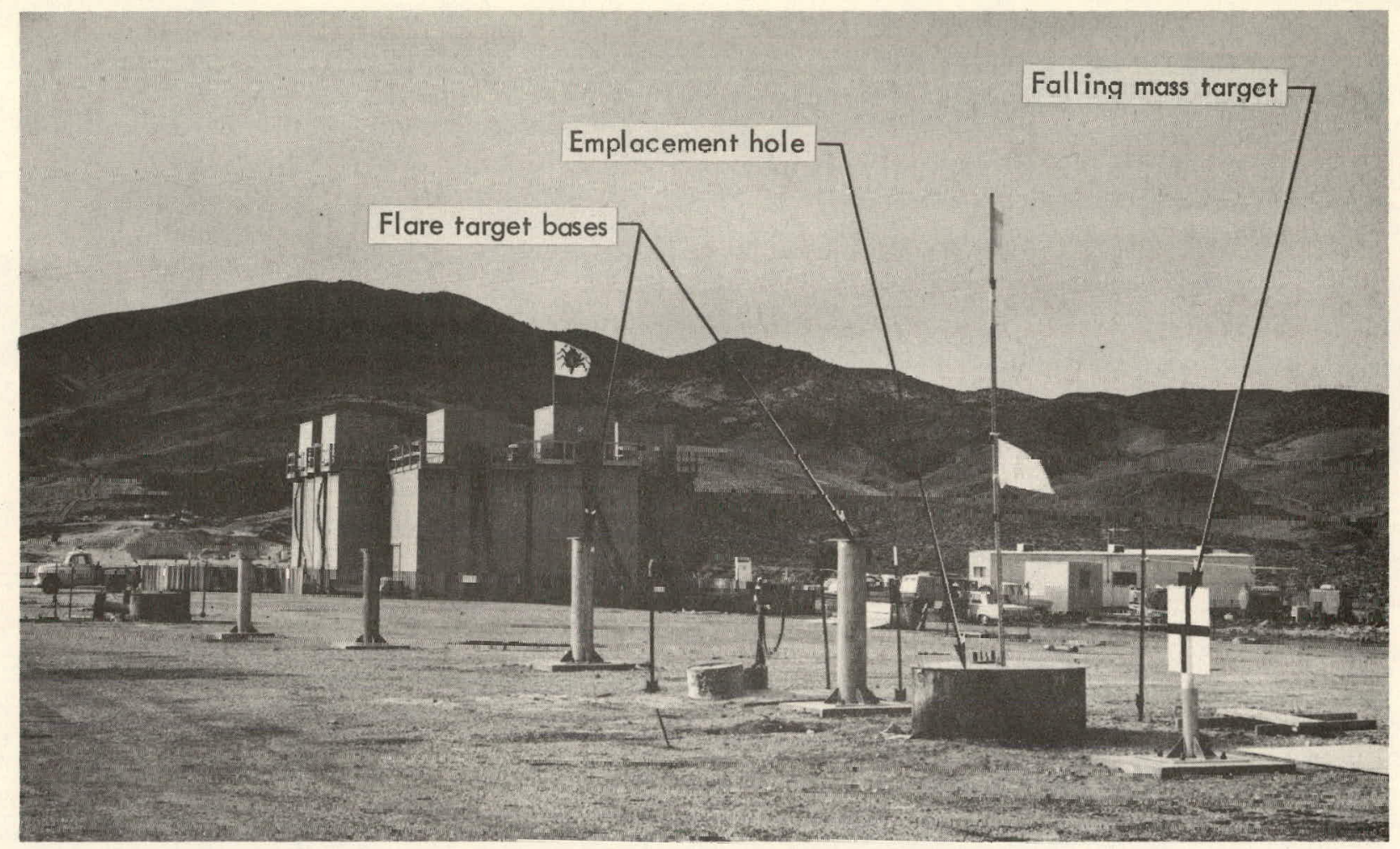

Fig. 2. View of Buggy array from near hole A.

four was aligned perpendicular to the midpoint between $\mathrm{C}$ and $\mathrm{D}$. One of these eight flares was too close to the edge of the film to be read by the Eyeball technique, so only seven are numbered.

The flare array along the Buggy line of charges contained 23 flares as shown in Fig. 1. Data was obtained from 16 of the 23 flares, and they are the ones numbered in Fig. 1. The light from the seven flares from which no data was obtained was of too low intensity, or varied greatly in intensity during the time of interest, and could not be consistently detected by the Eyeball computer system.

The surface motion arrays were photographed from two camera stations, each of whose line of sight was approximately perpendicular to the target array being photographed. The array along the line of charges was photographed from a camera station $2040 \mathrm{~m}$ south of hole C on Dome Mountain. The two arrays perpendicular to the line of charges were photographed from a camera station about $2100 \mathrm{~m}$ west of hole C.

The high contrast film from the camera stations, which shows only the flares and their fiducials, is read with the Eyeball computer program. The Eyeball program for reading target data is designed for the Digital Equipment Corporation PDP-1 computer, equipped with a CRT. The recorder CRT performs the actual reading. A film transport loaded with the developed $35-\mathrm{mm}$ film is placed between the precision CRT and a photomultiplier tube, and is focused on the precision CRT face, which projects the image of the CRT on the film plane. The photomultiplier tube 
is directly behind the film so that light from the CRT passing through the developed film is detected by the photomultiplier in a lighttight environment. Then, starting from a point of known position on the CRT, the film is scanned until a perimeter point in an image is detected. The average $\mathrm{x}$ and $\mathrm{y}$ CRT coordinates of the perimeter points are determined, and their intersection is assumed to be the center of the image. The CRT coordinates of each light spot in the frame of film are stored on magnetic tape. This tape is used as the input for a 7094 computer code which performs a coordinate transformation, smooths the target displacement data, and computes velocity components of each target as a function of time. ${ }^{1}$

\section{FALLING MASS EXPERIMENTS}

In order to study the early $(0-300 \mathrm{msec})$ surface motion history above charges $\mathrm{A}$ and $\mathrm{C}$, two falling-mass experiments were conducted close to emplacement holes A and C. These were the standard fallingmass experiments conducted on previous nuclear cratering events. A bowling ball is dropped from a known height at detonation time, and a high-speed motion picture camera photographs it relative to a target coupled into the surface. The targets in this case were smaller than those used on previous events. These targets were $2 \mathrm{ft}$ square with a "+" marked on them. The target is shown in Fig. 2. To give a dark background to contrast with the white ball, a black plywood backdrop was placed behind the bowling ball and the target. The small target moves with the velocity of the ground and the bowling ball serves as a fiducial point after a correction is made for $S=\frac{1}{2} \mathrm{gt}^{2}$. The initial distance from center of ball to center of reference target was $8.15 \mathrm{~m}$ for the experiment near hole $\mathrm{A}$ and $8.4 \mathrm{~m}$ for the experiment near hole C. Each target was about $3.04 \mathrm{~m}$ east of the hole.

The falling mass experiment were photographed from two camera stations. At the Dome Mountain station, $2040 \mathrm{~m}$ away, two cameras were focused with a narrow field of view on the falling mass experiments. In addition, two cameras were placed in a shielded container stationed about $610 \mathrm{~m}$ south of hole C. These cameras were the Bimat type, which fixed the film a short time after exposure and thus decreased the probability that the film would be fogged by contamination or radiation.

The film was read on the microscope digitizer, and five-digit $\mathrm{x}$ and $\mathrm{y}$ coordinate positions were punched on data cards. The cards serve as input to the $7094 \mathrm{com}$ puter program which determines displacements and velocities.

\section{ACCELEROMETERS}

A 15-element array of accelerometers (Endevco models 2246M15 and 2255) was used to measure vertical motion of the local surface (Fig. 1). Positions A-1 to A-5 and A-12 to A-15 had transducers with linear response $( \pm 5 \%)$ over the frequency range of 2 to $7000 \mathrm{~Hz}$ and a peak acceleration limit for shock of $2000 \mathrm{~g}^{\prime} \mathrm{s}$. The corresponding values for the accelerometers used at locations A-6 to A-11 were 2 to $10,000 \mathrm{~Hz}$ and $15,000 \mathrm{~g}^{\prime} \mathrm{s}$.

${ }^{1}$ R. W. Terhune, R. L. Fulton, and J. B. Knox, Surface Motion Photography Data Reduction by Digital Computers, Lawrence Radiation Laboratory, Livermore, Rept. UCRL-14155 (1965). 


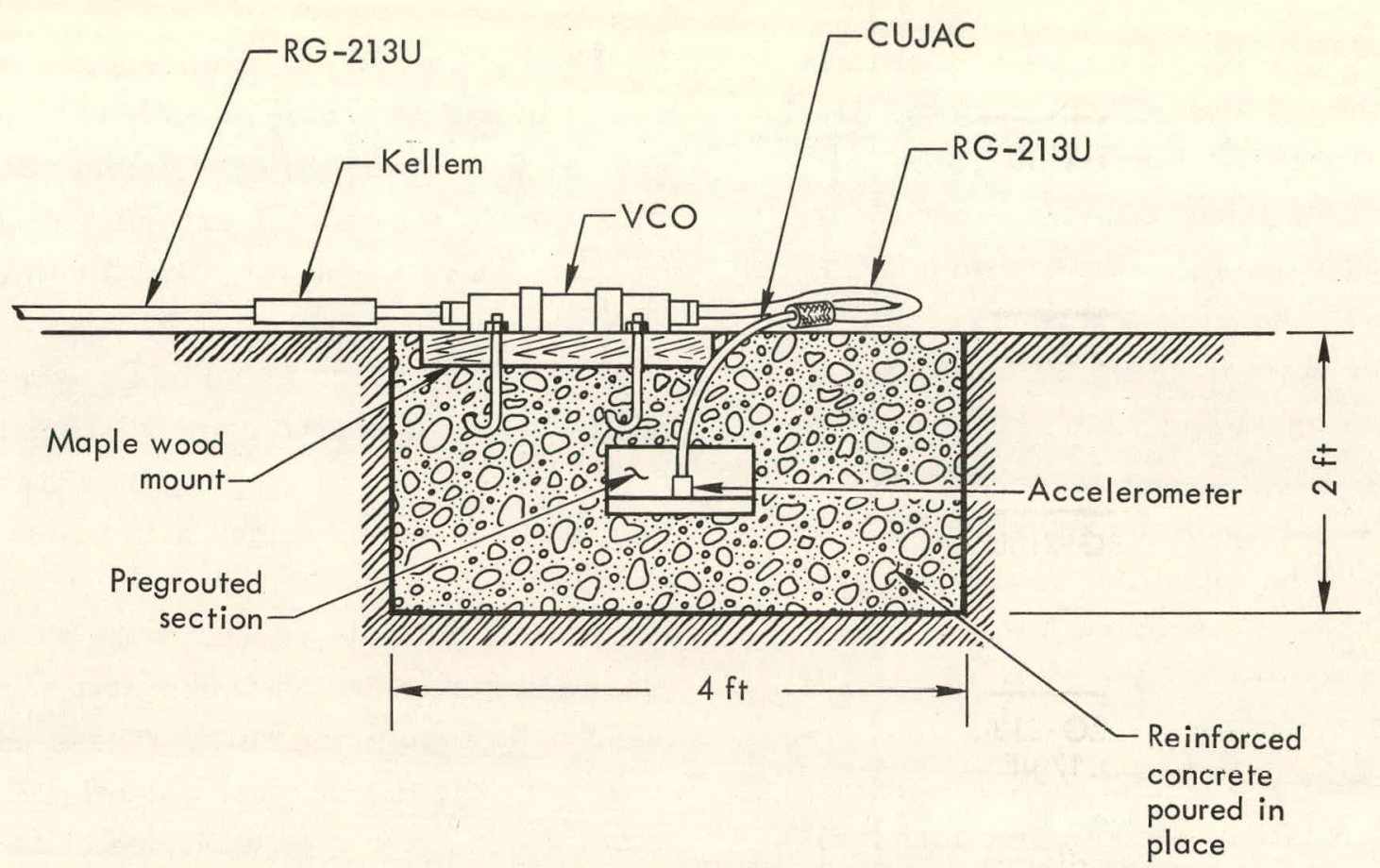

Fig. 3. Typical accelerometer installation.

The accelerometers, their associated electronics, and the cabling were installed so that the response would be that of the surroundings for 100 to $200 \mathrm{msec}$. Each accelerometer, with $2 \mathrm{ft}$ of copperjacketed coaxial cable (CUJAC), was cast into a reinforced concrete pad. ${ }^{*}$ With the exception of installations A-7, A-9, and A-10, we bolted a voltage-controlled oscillator (VCO) along with a thick maple block directly to each pad. Each VCO was hardpotted to withstand the expected acceleration which would be mitigated by the maple block. A short flexible cable, type RG-213U, completed the accelerometerVCO circuit. The CUJAC and this jumper were bent so that the exposed cable and connectors would be supported by the pad (Fig. 3).

\footnotetext{
*Accelerometer with CUJAC cable was precast at LRL-Livermore into a 12-in.diam by 6 -in.-thick concrete round.
}

For installations A-7, A-9, and A-10 the VCO's hung about $3 \mathrm{ft}$ above the ground from a support frame of steel posts and 1/8-in. wire cable. The support for A-7 was close to the concrete pad, and a $10-\mathrm{ft}$ length of signal cable bridged the CUJACVCO separation. The electronic packages for A-9 and A-10 were hung $210 \mathrm{ft}$ north of the charges. Approximately $300 \mathrm{ft}$ of RG-213U cable ran from these pad installations to the $\mathrm{VCO}^{\prime} \mathrm{s}$.

In about $200 \mathrm{msec}$ this array would move tens of feet vertically. Therefore, all signal cables from the VCO's to the remote recording facility had the needed length in the area of motion to prevent early tension failures. The connectors at the VCO were protected from cable loading by the use of Kellem grips (Fig. 3). Normal precautions were taken to protect all cabling from sharp edges and weather.

Each voltage-controlled oscillator had a carrier frequency of $1 \mathrm{MHz}$ with $200 \mathrm{kHz}$ 


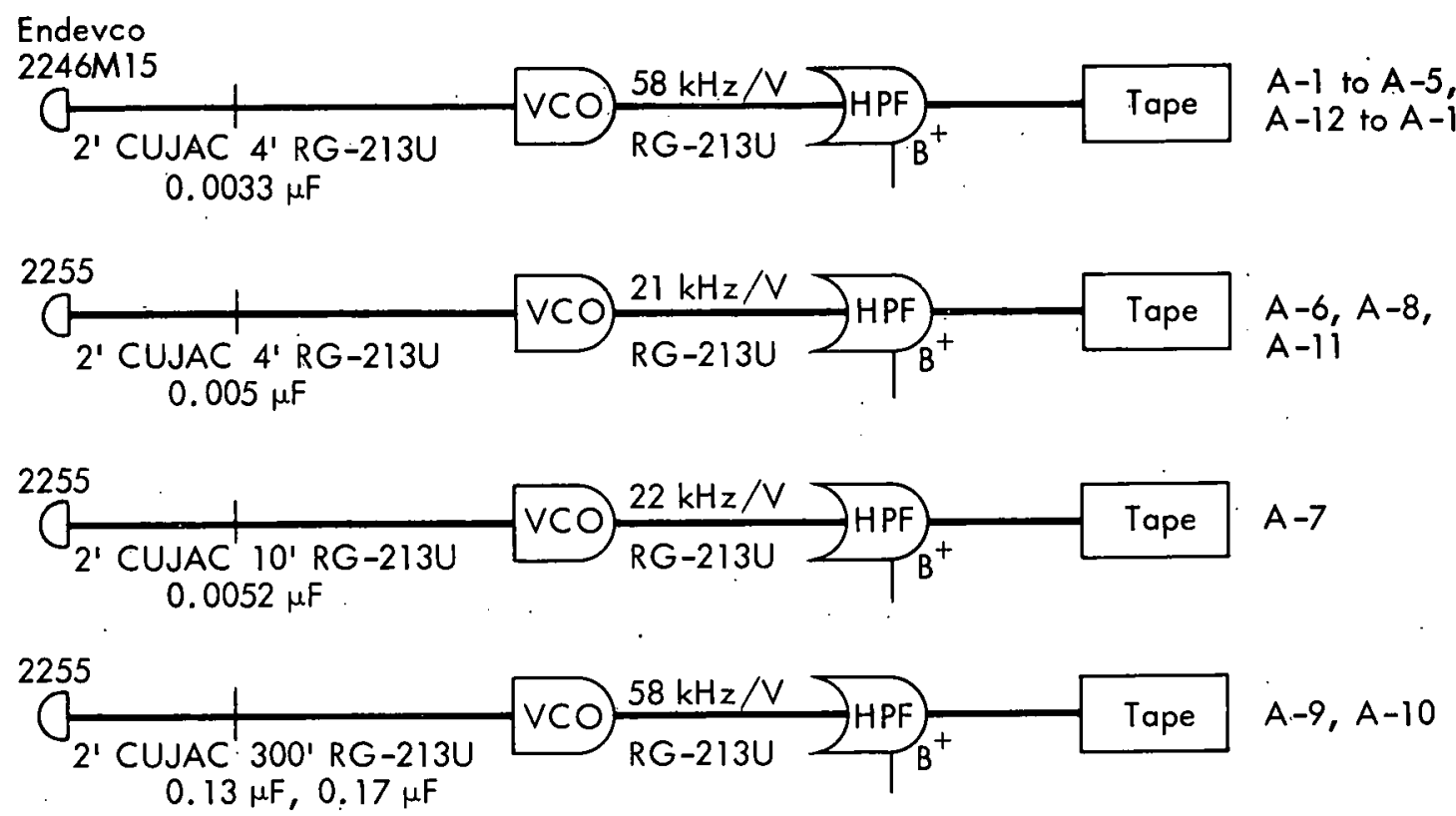

Fig. 4. One-line diagram of electronic recording system for accelerometers.

of modulation. This FM signal, after filtering, was recorded on magentic tape, " as shown in Fig. 4. The tape was later played back at the data reduction facility at Livermore. Carrier signals were demodulated, displayed on a playback oscilloscope, and photographed. The signals were digitized for computer processing to obtain the acceleration and velocity.

Special sets of velocity transducers and accelerometers ${ }^{\dagger}$ were added to the falling mass experiments at holes $A$ and
C. These transducers were contained in aluminum cans set in reinforced concrete pads. One pad was located in the center of the support legs of each tower of the falling mass test. We used Duxseal packing in the cans to attenuate mechanical ringing. The accelerometer signals were integrated electronically. Three $\mathrm{VCO}^{\prime} \mathrm{s}$ per installation were suspended about $18 \mathrm{ft}$ in the air for shock isolation. The electronic system was the same as that for the full accelerometer array. (See previous discussion.)

\section{Experimental Results}

\section{TARGET FLARES}

The vertical components of displacement of the flares are presented in the

\footnotetext{
*Two Hewlett-Packard 1.5-MHz tape machines were used for field recording.

${ }^{\dagger}$ Spartan Southwest 601 velocity gauge with an Endevco 2255 at hole A. Accelerometer at $\mathrm{C}$ was a Statham A-5.
}

hodograph in Fig. 5. The first vent of luminous gas occurred over charge $\mathrm{C}$ at about $1 \mathrm{sec}$ after zero time, and there was some venting over charge $B$ just after this. The peak vertical displacement at vent time was at target 10 , to the left of charge $C$. At vent time this displacement was about $31 \mathrm{~m}$. From the hodograph the 
greatest vertical displacement before venting occurs in the area of charges $B$ and $\mathrm{C}$.

The vertical components of velocity for the targets along the axis of charges at various times after detonation are presented in Fig. 6. The vertical velocities at $0.150 \mathrm{sec}$ are the peak spall velocities

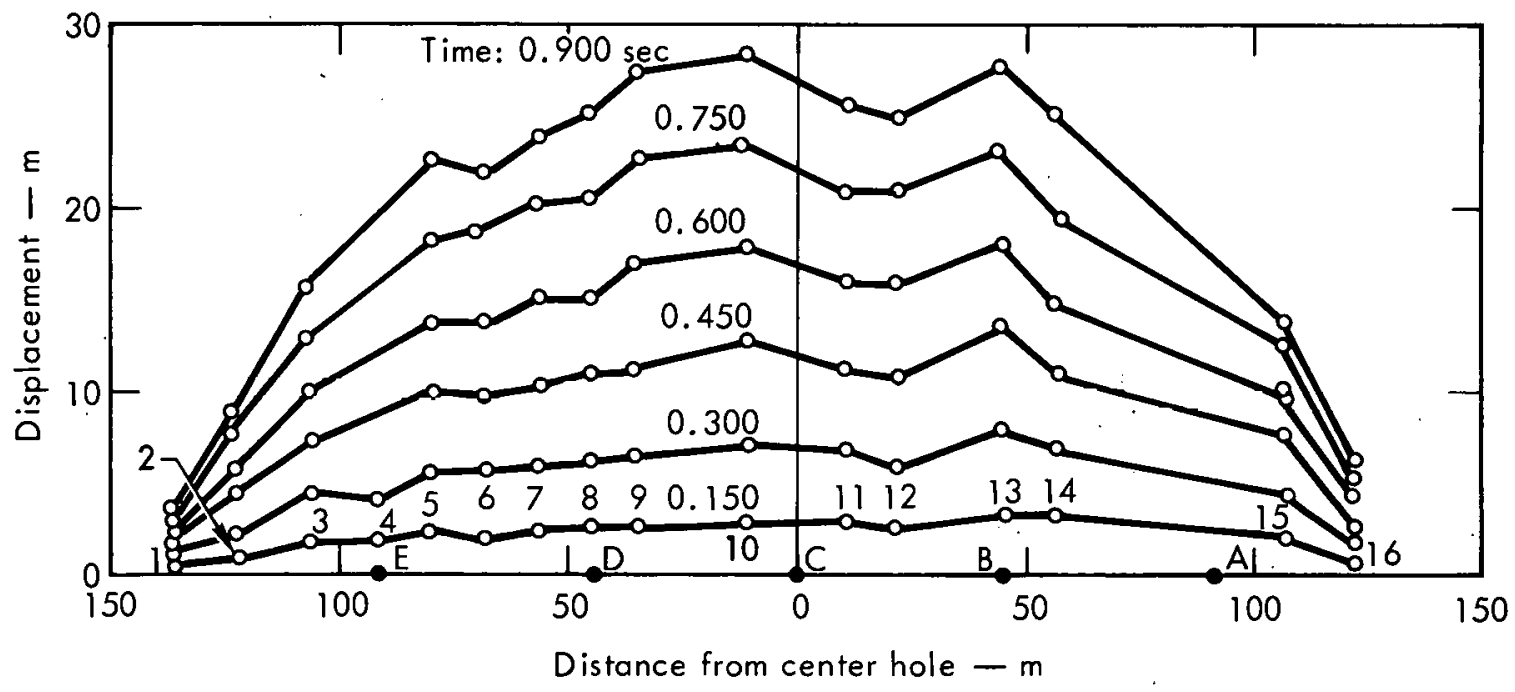

Fig. 5. Vertical displacements of targets along axis of charges at various times.

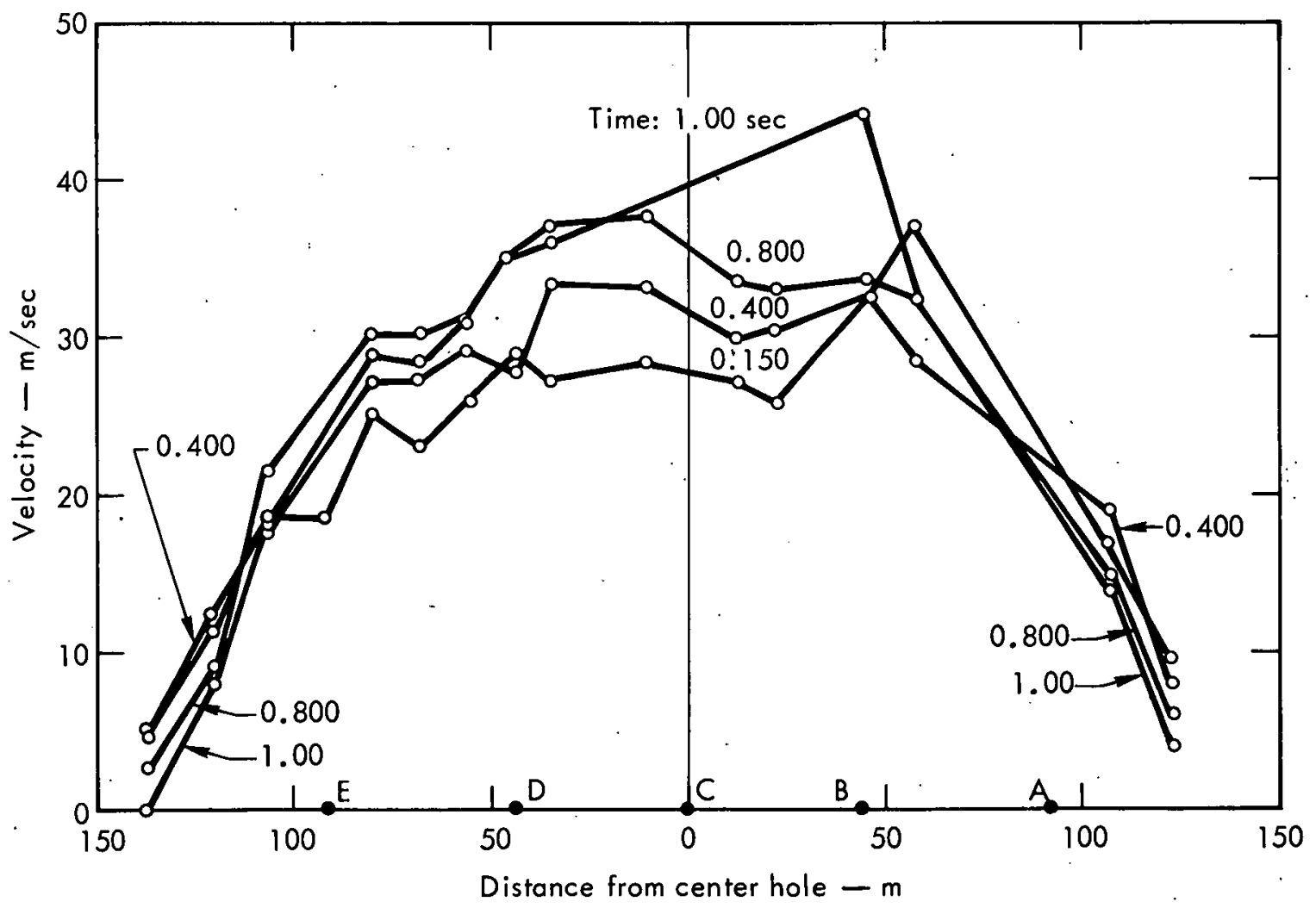

Fig. 6. Vertical velocities of targets along axis of charges. 


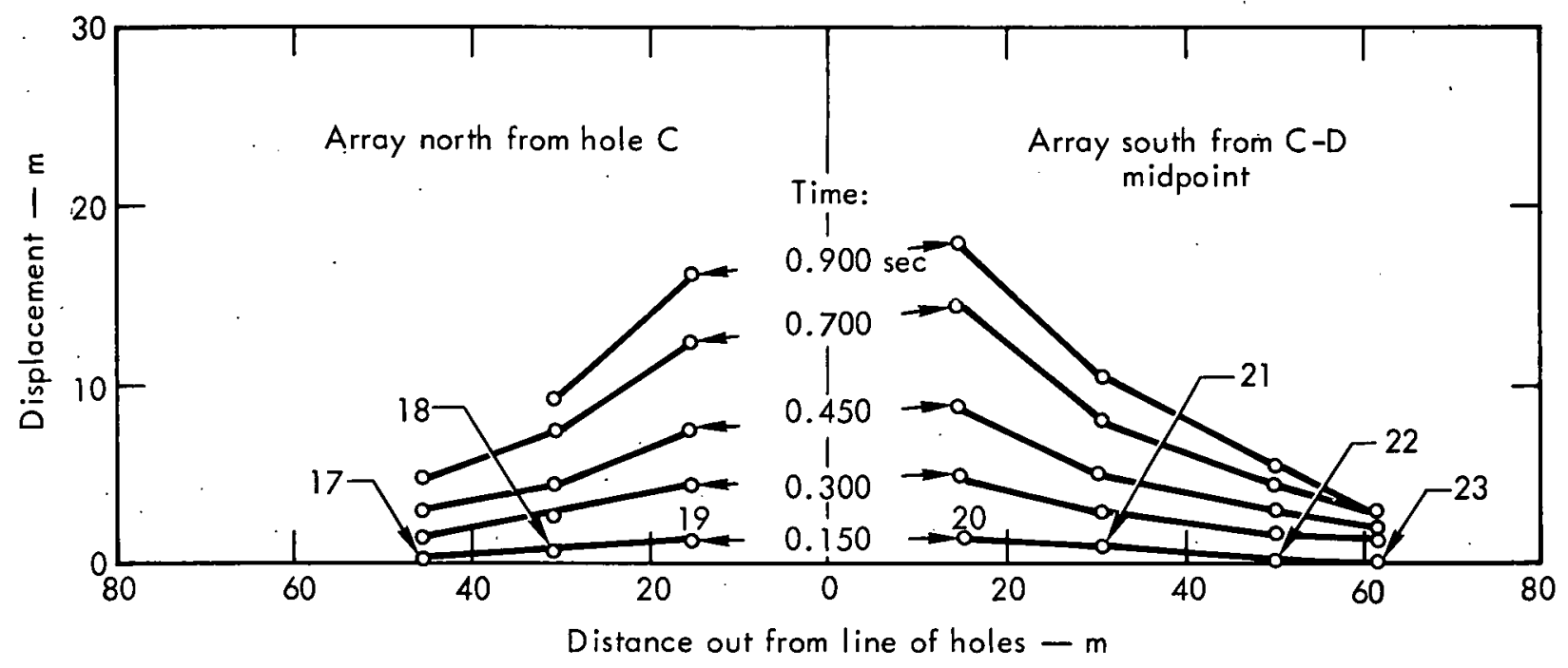

Fig. 7. Vertical displacements along the cross arrays.

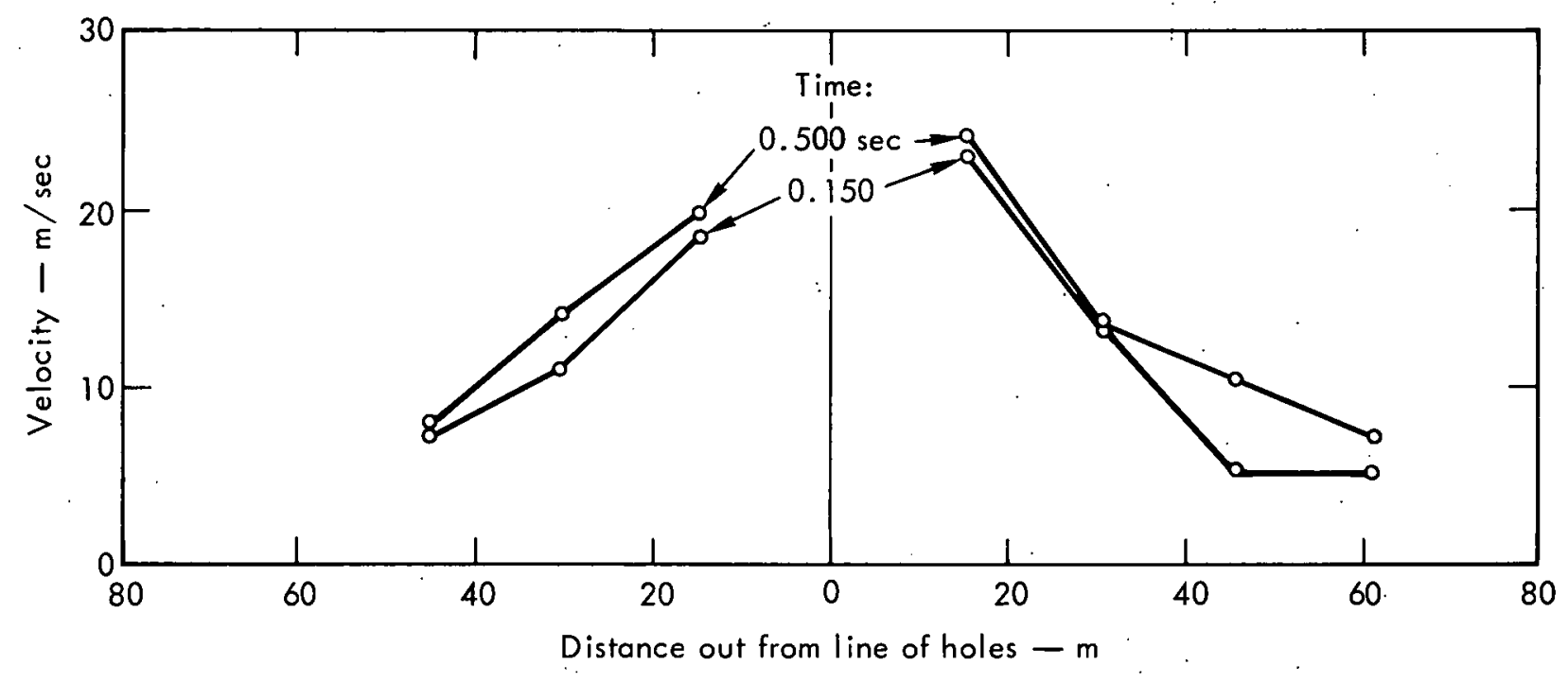

Fig. 8. Vertical velocities along the cross arrays.

and are due to spall caused by the emerging compressive wave. At this time the peak velocity of about $32 \mathrm{~m} / \mathrm{sec}$ occurs at target 13 next to charge $B$. At vent time $(\sim 1 \mathrm{sec})$ the peak velocity of about $44 \mathrm{~m} / \mathrm{sec}$ again occurs at target 13. This may not be the peak velocity along the mound at this time as the light from some of the flare targets has been obscured.

Figures 7 and 8 are hodographs of the vertical components of displacement and velocity of the two target arrays that were perpendicular to the line of charges. Of particular interest is the comparison between target 19 , which is $50 \mathrm{ft}$ out from charge $\bar{C}$, and target 20 , which is $50 \mathrm{ft}$ out from the midpoint between $C$ and $D$. Respective velocities at $0.150 \mathrm{sec}$ are $19 \mathrm{~m} / \mathrm{sec}$ and $25 \mathrm{~m} / \mathrm{sec}$. Target $20^{\prime} \mathrm{s}$ higher velocity is attributed to its location at a point where interaction between the two charges is felt. 
The majority of the flares remained visible until vent time, at about $+1 \mathrm{sec}$, and several were observed up to $+1.7 \mathrm{sec}$.

Figures A-1 through A-48 in the Appendix give the vertical displacements of the target array along the line of charges for various smoothing parameters. Figures A-49 through A-65 show the horizontal displacements of these same targets.

Figures A-66 through A-72 show the vertical displacement as a function of time for the two cross arrays. Figures $A-73$ through $A-79$ illustrate the vertical velocity of the cross arrays, and Figs. A-80 through A-95 illustrate the vertical velocity of the targets along the charges.

\section{FAL, LING MASS EXPERIMENTS}

The film selected for data reduction for the bowling ball experiment at hole $C$ was from one of the cameras on Dome Mountain. Figure 9 shows the vertical displacement of the bowling ball target at

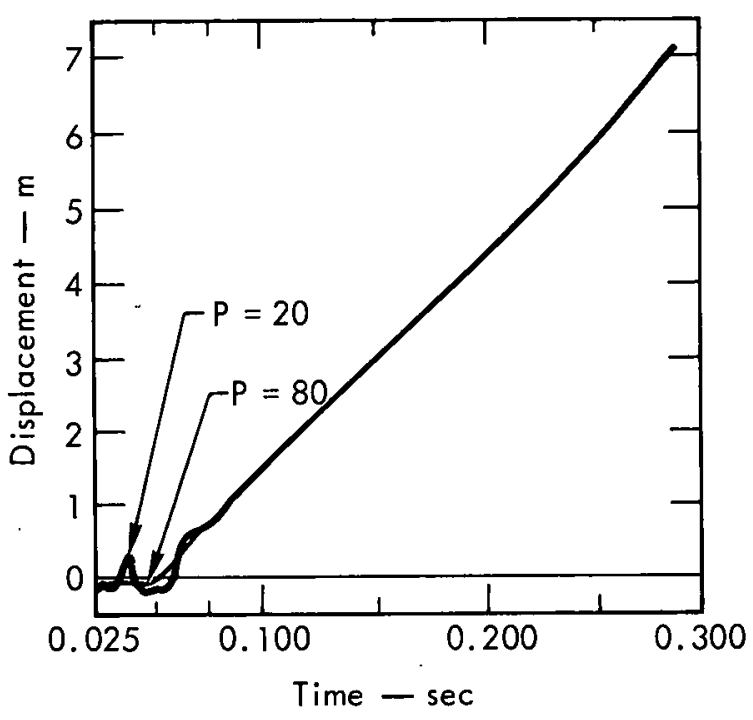

Fig. 9. Vertical displacement of falling mass target at hole $C$. Smoothing parameters $P=20$ and $P=80$.
$C$ versus time for two smoothing parameters, $P=20$ and $P=80$. The sharp increase in displacement beginning at about $0.035 \mathrm{sec}$ on the $P=20$ curve is due to a very erratic point in the data. In addition, a sharp increase in the displacement occurs at about $0.056 \mathrm{sec}$. This is due to a temporary misreading of the position of the target top. A telemetry tower was inadvertently located between the bowling ball at charge $\mathrm{C}$ and the camera station on Dome Mountain. The top of the target was temporarily lost as it rose behind one of the wooden cross bars, and was found to be $1.6 \mathrm{ft}$ closer to the bowling ball than previous microscope readings indicated. A sudden adjustment in the microscope positioning caused the sharp increase in displacement.

Figure 10 shows the vertical velocity of the bowling ball target at $C$ versus time. The first sharp peak of velocity, which has a maximum value of about $42 \mathrm{~m} / \mathrm{sec}$, should not be considered valid because of the target position problem discussed above. The peak velocity actually occurs somewhat later, between 90 and $100 \mathrm{msec}$, and is about $32 \mathrm{~m} / \mathrm{sec}$.

The second bowling ball experiment was set up about $3.04 \mathrm{~m}$ from emplacement hole A. The film used for this experiment was from the camera station $610 \mathrm{~m}$ from charges $\mathrm{A}$ and $\mathrm{C}$. The early vertical velocity of this target is shown in Fig. 11. The zero-time flash bulb obscured the target, and in addition some frames of film were used for scaling. Therefore the time history does not begin until $+100 \mathrm{msec}$, and the zero time in Fig. 11 is about $+10 \mathrm{msec}$. The peak velocity is about $24 \mathrm{~m} / \mathrm{sec}$, which occurs at about $80 \mathrm{msec}$. 


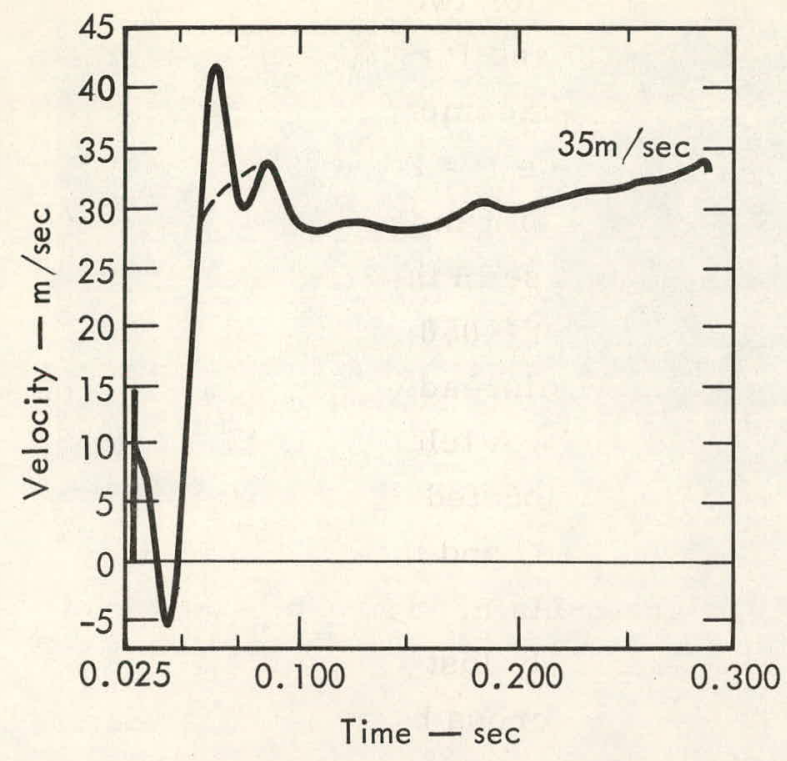

Fig. 10. Vertical velocity of falling mass target at hole C. Smoothing parameter $\mathrm{P}=80$.

One of the special accelerometers associated with the falling mass targets failed early; the second had a high-frequency ringing $(\sim 10 \mathrm{kHz})$ with no evidence of an acceleration pulse. Both integrations failed. The velocity gauges produced the correct signal form, indicating onset of surface motion at $0.025 \mathrm{sec}$ after shot time at the $\mathrm{C}$ hole and $0.03 \mathrm{sec}$ at the A hole. Signal peak occurs at 0.08 to $0.09 \mathrm{sec}$, and commencing at about $160 \mathrm{sec}$ the signal again rises.

The peak velocities from the accelerometer data are $15.8 \mathrm{~m} / \mathrm{sec}$ at $\mathrm{C}$ and $12.5 \mathrm{~m} / \mathrm{sec}$ at $\mathrm{A}$ if a gauge sensitivity based on a static calibration is used. These are only about half the peak values indicated by the falling mass experiments. Furthermore, the gauges indicate an acceleration of only $0.5 \mathrm{~g}$ during the expected free-fall portion of the surface motion. If one assumes a dynamic sensitivity twice the statically derived one, the gauges would show $1 \mathrm{~g}$ during the free-fall period and the peak spall velocities would then be $31.6 \mathrm{~m} / \mathrm{sec}$ and $25 \mathrm{~m} / \mathrm{sec}$ at $\mathrm{C}$ and $\mathrm{A}$, respectively. These values would be in excellent agreement with the falling mass data.

\section{ACCELEROMIETERS}

Carrier signals were recovered from all channels. This data lasted for some 4 sec after zero time (Fig. 12). For all channels only the first positive acceleration pulse was integrated for velocity; and, in addition, the records of $A-1, A-9, A-10$, and $A-13$, which appeared amenable to the correction, were integrated after a suitable base-line shift. Table 1 lists the positions and measured values from the accelerometer experiments.

The surface acceleration data from the Endevco accelerometers as a function of time is presented in Figs. A-96 through A-110 in the Appendix.

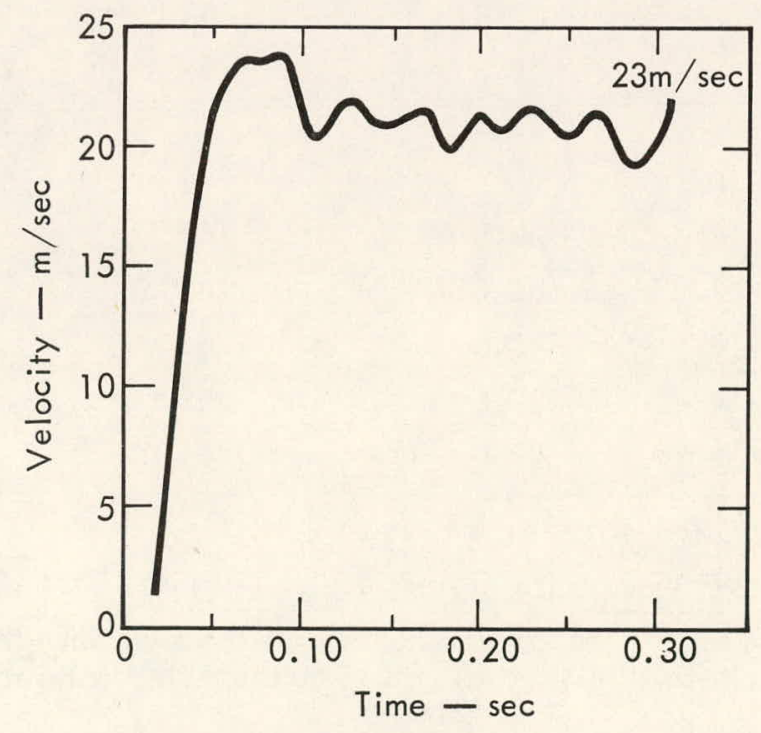

Fig. 11. Vertical velocity of falling mass target at hole $\mathrm{A}$. 

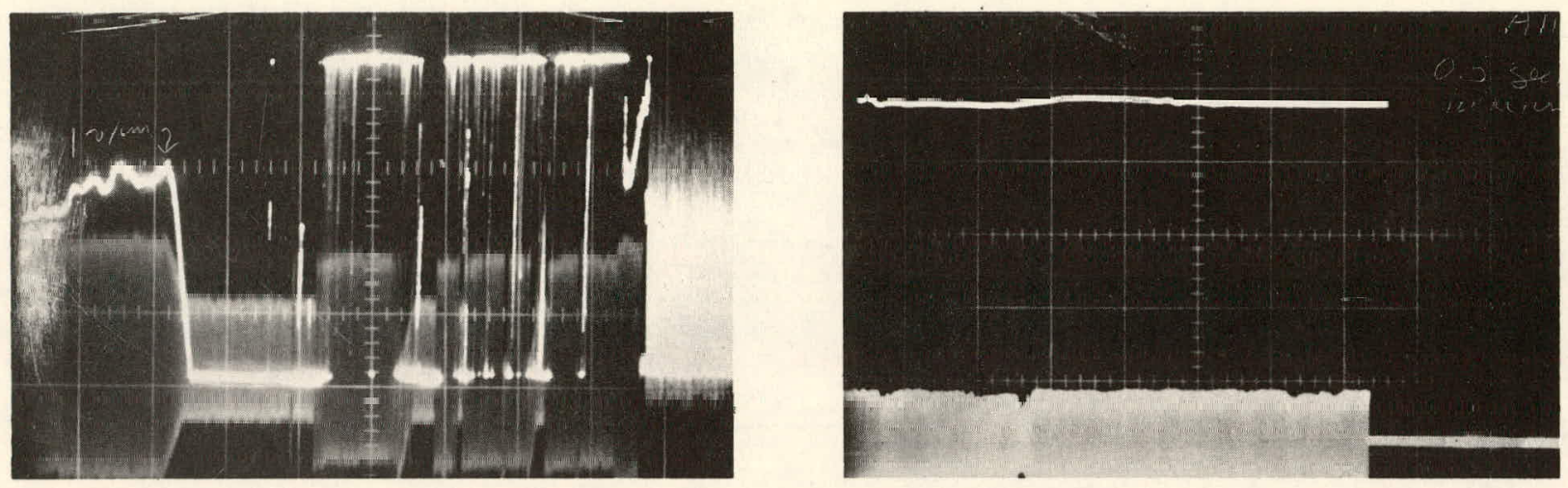

Fig. 12. Typical accelerometer data: left, A-10; right A-11. Top sweep is analog of acceleration signal, bottom sweep is the FM carrier signal. Sweep speed $0.5 \mathrm{sec} / \mathrm{div}$.

Table 1. Accelerometer data summary.

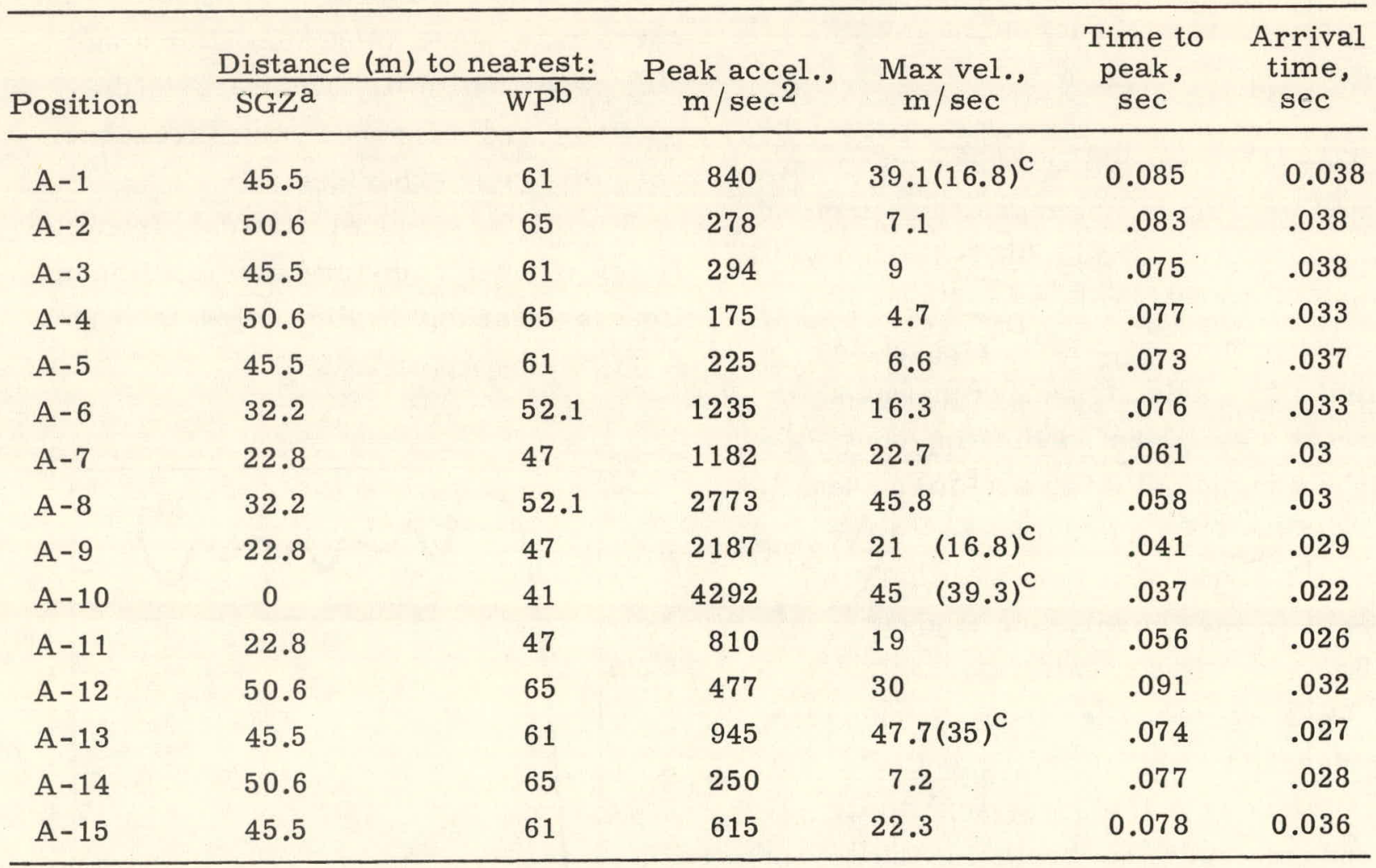

${ }^{a}$ SGZ $=$ surface ground zero.

${ }^{b} \mathrm{WP}=$ working point, i.e., charge location.

${ }^{\mathrm{c}}$ Value without brackets obtained by integrating first positive peak only. Value in brackets obtained by integrating after a base line shift. 


\section{Discussion of Results}

An interesting comparison can be made between the velocities of the targets in the two arrays perpendicular to the line of charges in Buggy. Target 19 which is $50 \mathrm{ft}$ out from the central charge $C$ has an early peak spall velocity of about $19 \mathrm{~m} / \mathrm{sec}$, whereas target $20,50 \mathrm{ft}$ out from the midpoint between charges $C$ and $D$, has an early peak spall velocity of about $25 \mathrm{~m} / \mathrm{sec}$.
A similar relationship exists for the targets farther out on these cross arrays. Targets 18 and $21,100 \mathrm{ft}$ out from $\mathrm{C}$ and the $\mathrm{C}-\mathrm{D}$ midpoint respectively, show peak spall velocities of 11.5 and $14+\mathrm{m} / \mathrm{sec}$. Targets 17 and $22,150 \mathrm{ft}$ out from $\mathrm{C}$ and the $\mathrm{C}-\mathrm{D}$ midpoint respectively, have peak spall velocities of 7.5 and $10.5 \mathrm{~m} / \mathrm{sec}$.

- Figure 13 shows this enhancement in peak vertical spall velocity, which is due

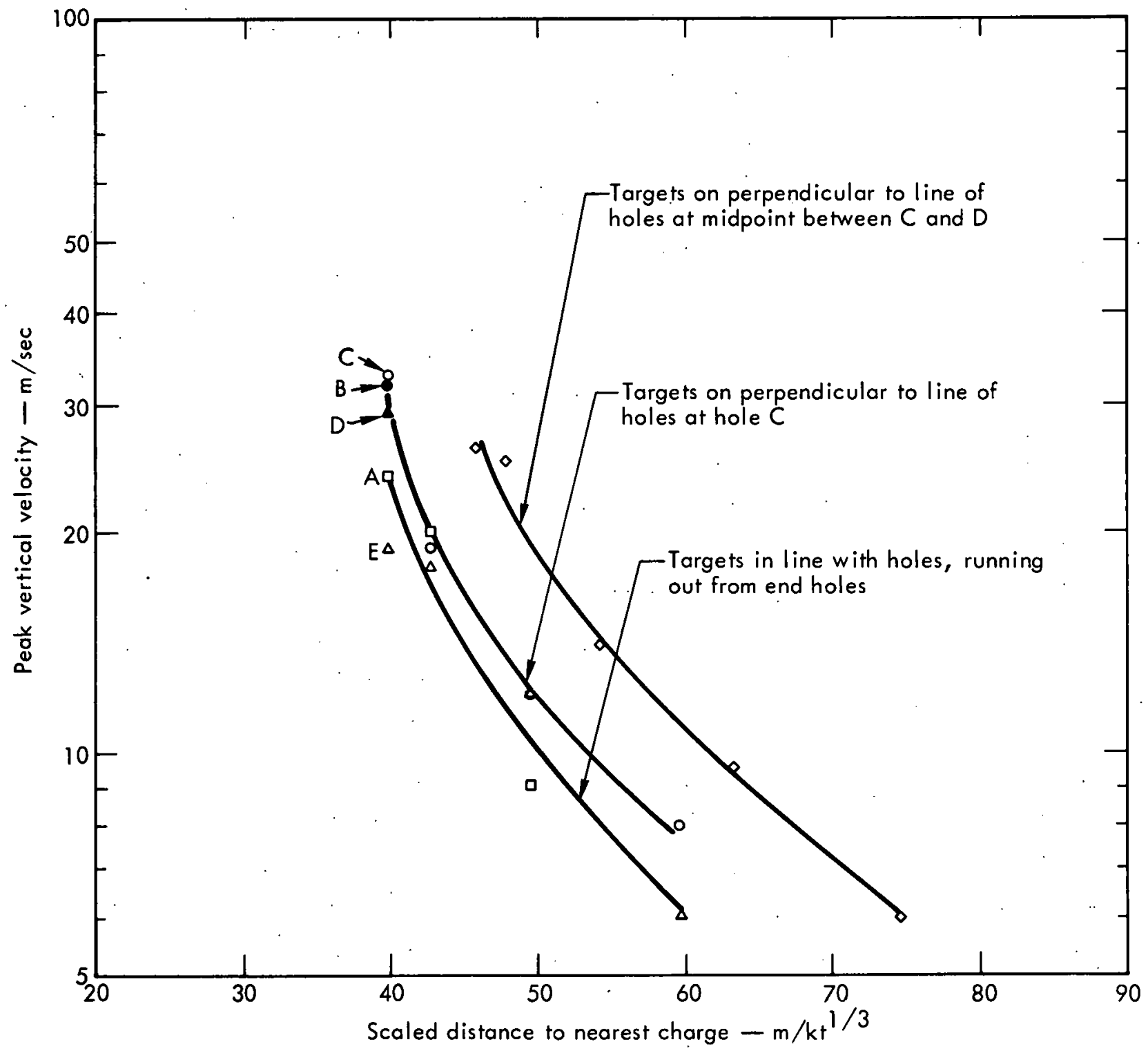

Fig. 13. Enhancement of peak vertical velocity by charge interaction. Peak velocities are plotted for targets on the two cross arrays and for targets at corresponding distances beyond the end holes. 
to charge interaction. The enhancement is greatest for targets equidistant from charges $\mathrm{C}$ and $\mathrm{D}$. There is also enhancement for targets on the array perpendicular to $C$ as compared to similar targets east of $A$ and west of $E$, outside the charge array. .

The length of signal recovered from each accelerometer indicates that the basic mechanical elements of the installation hcld together during this period of mound motion. Each record, though, exhibits either some large positive and negative excursions or a longer term steady off set from zero acceleration called a base line shift (Fig. 12). Subsequent tests with high explosive sources were used to verify that the RG-213U jumper cable when shocked can generate large noise signals. This is the likely source for the transient noise. The source of the base line shift, which in some cases was $25 \%$
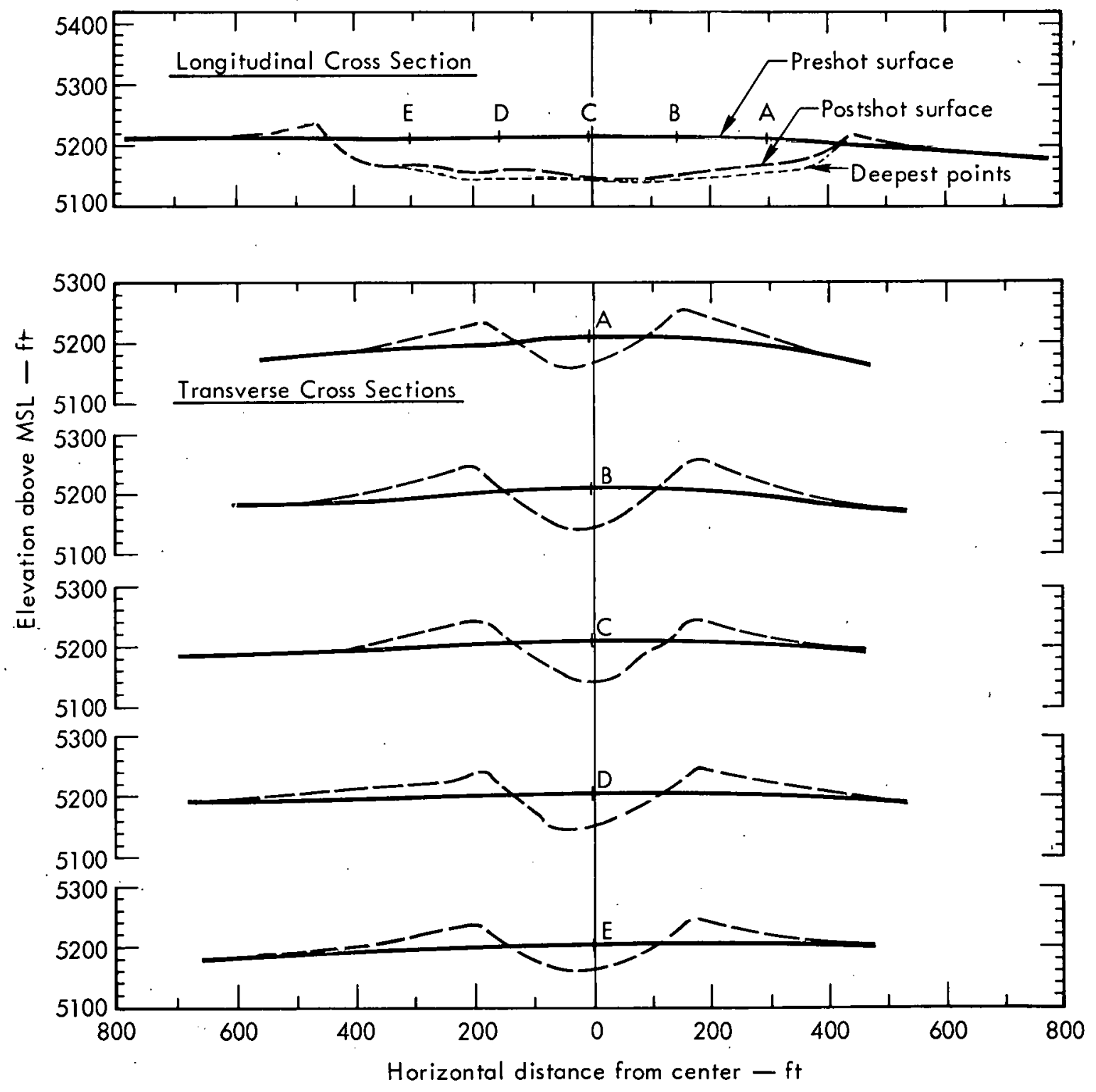

Fig. 14. Topographic profiles of the Buggy crater: 
of the peak signal, is unknown at this time.

The different treatment of the VCO's for A-7, A-9, and A-10 caused no obvious improvement in the signal recovery, and the increased length of the flexible RG-213U may indeed be the source of the noise in the A-7 and A-10 signals. Table 2 is a selection of results from the three systems of measurement.

Because of the symmetry limitations of present computer codes, only single explosives were calculated for effects. The peak vertical spall velocities at the ground above each shot were computed to be 25 to $35 \mathrm{~m} / \mathrm{sec}$. According to Robert Terhune of LRL-Livermore, the major source of this variation is the specific geological layering for the five charges. The values derived from measurements varied from 24 to $40 \mathrm{~m} / \mathrm{sec}$. With the exception of the peak spall velocities observed at surface ground zero over charges $B$ and $C$, the velocities along the line between the charges have a distribution that peaks at $26 \mathrm{~m} / \mathrm{sec}$ with a spread of. $3 \mathrm{~m} / \mathrm{sec}$. For a homogeneous medium, such uniform motions of an initially flat area should produce a uniform crater. Postshot crater studies confirm this point (Fig. 14).

Table 2. Selected results of measured surface motion as a function of horizontal distance from top of nearest hole.

\begin{tabular}{|c|c|c|c|}
\hline Distance, $m$ & Type of measurement & $\begin{array}{c}\text { Peak velocity, } \\
\mathrm{m} / \mathrm{sec}\end{array}$ & $\begin{array}{c}\text { Peak acceleration, } \\
\mathrm{m} / \mathrm{sec}^{2}\end{array}$ \\
\hline$\sim$ & $\begin{array}{l}\text { Falling mass expt. at } \mathrm{C} \\
\text { Accelerometer } \mathrm{A}-10\end{array}$ & $\begin{array}{l}33 \\
40\end{array}$ & 4290 \\
\hline 15.3 & $\begin{array}{l}\text { Target } 19, \text { north } \\
\text { Target } 20 \text {, south } \\
\text { Target } 15 \text {, east }\end{array}$ & $\begin{array}{l}19 \\
25 \\
20\end{array}$ & · \\
\hline 22.8 & $\begin{array}{l}\text { Accelerometer } A-7 \text {, north } \\
\text { Accelerometer } A-11 \text {, south }\end{array}$ & $\begin{array}{l}23 \\
19\end{array}$ & $\begin{array}{r}1180 \\
810\end{array}$ \\
\hline 30.4 & $\begin{array}{l}\text { Target } 18, \text { north } \\
\text { Target } 21 \text {, south }\end{array}$ & $\begin{array}{l}12 \\
14\end{array}$ & \\
\hline 45.5 & $\begin{array}{l}\text { Target } 17 \text {; north } \\
\text { Accelerometer A-2, north } \\
\text { Target } 22 \text {, south } \\
\text { Accelerometer A-14, south } \\
\text { Target } 1 \text {, west }\end{array}$ & $\begin{array}{l}8 \\
7 \\
9 \\
7 \\
6\end{array}$ & $\begin{array}{l}278 \\
250\end{array}$ \\
\hline 60.8 & Target 23, south & 6 & \\
\hline
\end{tabular}

${ }^{a}$.Vertical components of early $(<150 \mathrm{msec})$ surface motion. 


\section{Conclusions}

The variation of peak vertical spall velocity from one emplacement hole to another agreed with preshot calculations that included different layered models above each shot point.

'There was about a $50 \%$ enhancement of the peak vertical spall velocities due to multiple charge interaction. The scatter in the acceleration data is too large to determine any such enhancement there.

The velocity values and the crater dimensions verify the contention advanced by Robert Terhune of LRL that shear strength, degree of fracturing, and bulking properties were important in this experiment and should be part of the models for calculations.

When a consistent dynamic sensitivity (factor of 2 above the static value) is used for the velocity gauges at charges $A$ and $C$, the data from the gauges and the falling mass experiments are in excellent agreement. The acceleration measurement was successful in that it recorded the data for a long enough time, but additional effort is needed to eliminate extraneous noise before one can use the velocities integrated from this data with the same confidence as the velocities derived from the flare and falling-mass measurements. 


\section{Appendix}

\section{Sources of Error, Smoothing Parameters, Data Plots}

\section{SOURCES OF ERROR}

The primary source of error in the data reduction of the Buggy surface motion by photographic analysis is in the determination of the position of the target or flares on each frame of film. Shortly after zero time, the ground-shock-induced air blast around ground zero caused refraction of the light from the flares, making the absolute position of the flares difficult to determine for some tens of milliseconds.

For the bowling ball film, the unsmoothed vertical displacement data shows a scatter of $\pm 0.1 \mathrm{~m}$. The unsmoothed vertical displacement data from the target Eyeball film has a scatter of $\pm 0.3 \mathrm{~m}$.

\section{SMOOTHING PARAMETERS}

Various smoothing parameters are used in this report, because in the determination of the coordinate position of a point on a surface motion target by means of a microscope digitizer, or by the Eyeball technique, there is scatter in the observations. Therefore, some statistical considerations are employed to reduce the influence of the random errors and the reading errors. $P$ is the ratio of the number of observations to the minimum number of observations required in the absence of noise. In this context, $P$ times the data interval between observations is the effective data interval.

Figures A-1 through A-95 present the surface motion displacement and velocity over the Buggy mound for various smoothing parameters. The effect of the smoothing on the various displacements and velocities is readily seen. Surface acceleration data from the Endevco accelerometers are presented in Figs. A-96 through A-110. Figures $A-111$ and $A-112$ show the velocity of the surface as a function of time for the $\mathrm{A}$. and $\mathrm{C}$ holes as measured by the velocity gauges.

\section{DATA PLOTS}

Figures $A-1$ through $A-112$ are computer-plotted graphs of Buggy surface motion. The numbers along the axes are in the usual computer shorthand: E-03 means the numbers must be multiplied by $10^{-3}$ (e.g., $050 \rightarrow 0.050$ ), E 0 means the numbers must be multiplied by $10^{\circ}$ or 1 , $E+02$ means the numbers must be multiplied by $10^{2}$, etc. 


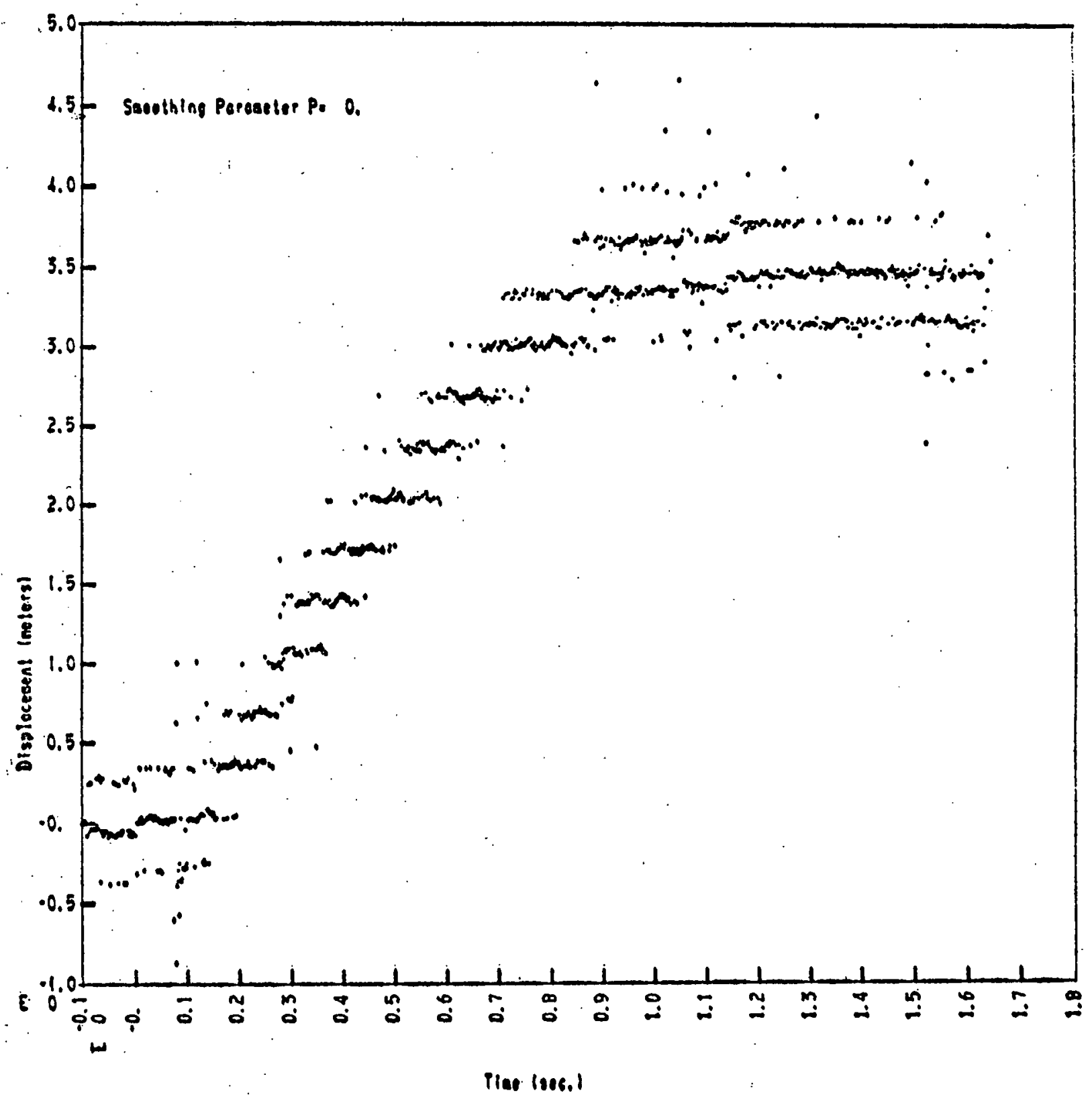

$$
\begin{gathered}
\text { FlGURE A-1 } \\
\text { Yertical Displacement Target } 1
\end{gathered}
$$

-18- 


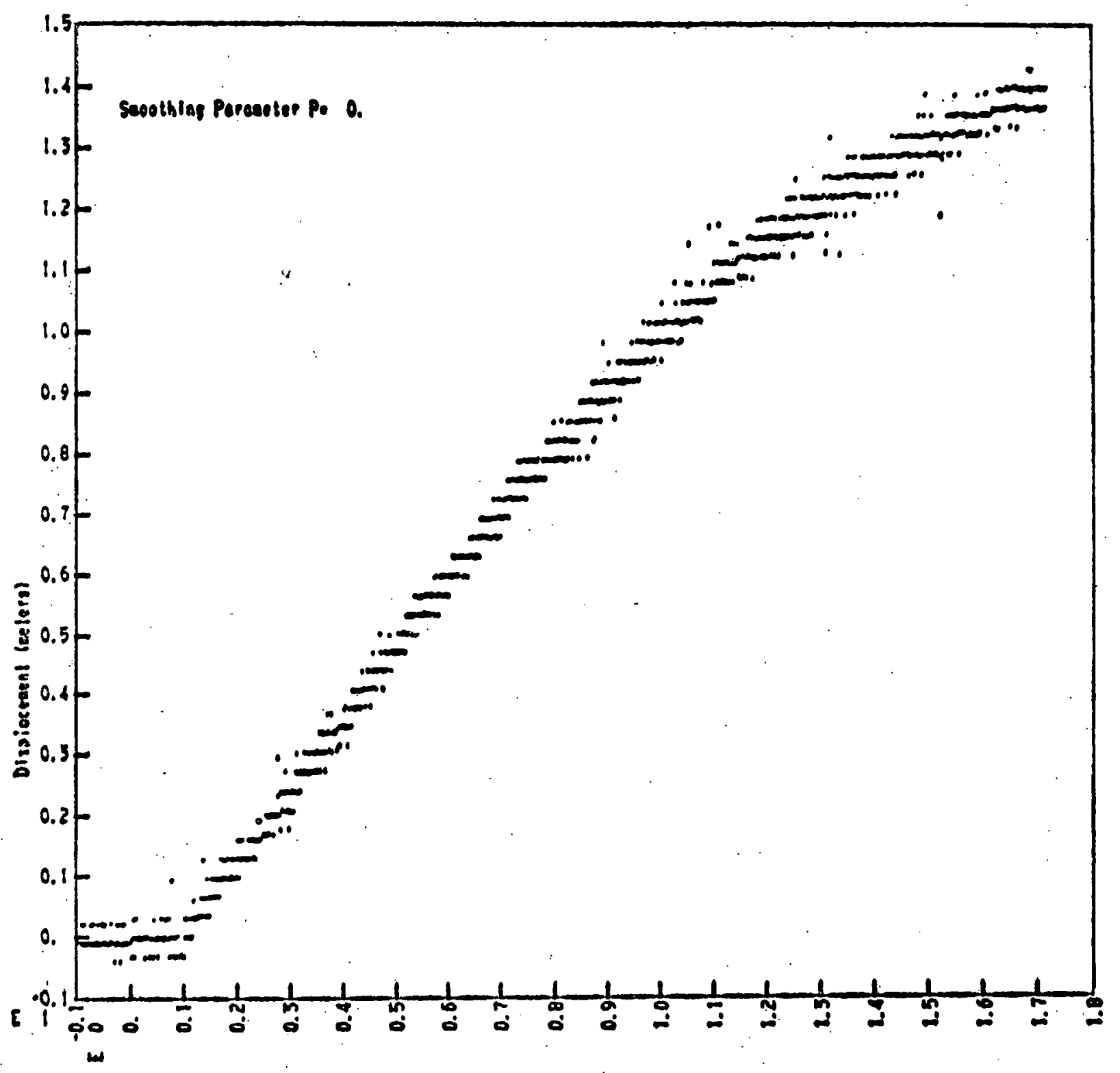

rise lsocel

FIGURE A-2

Vertical Displacement. Target 2 


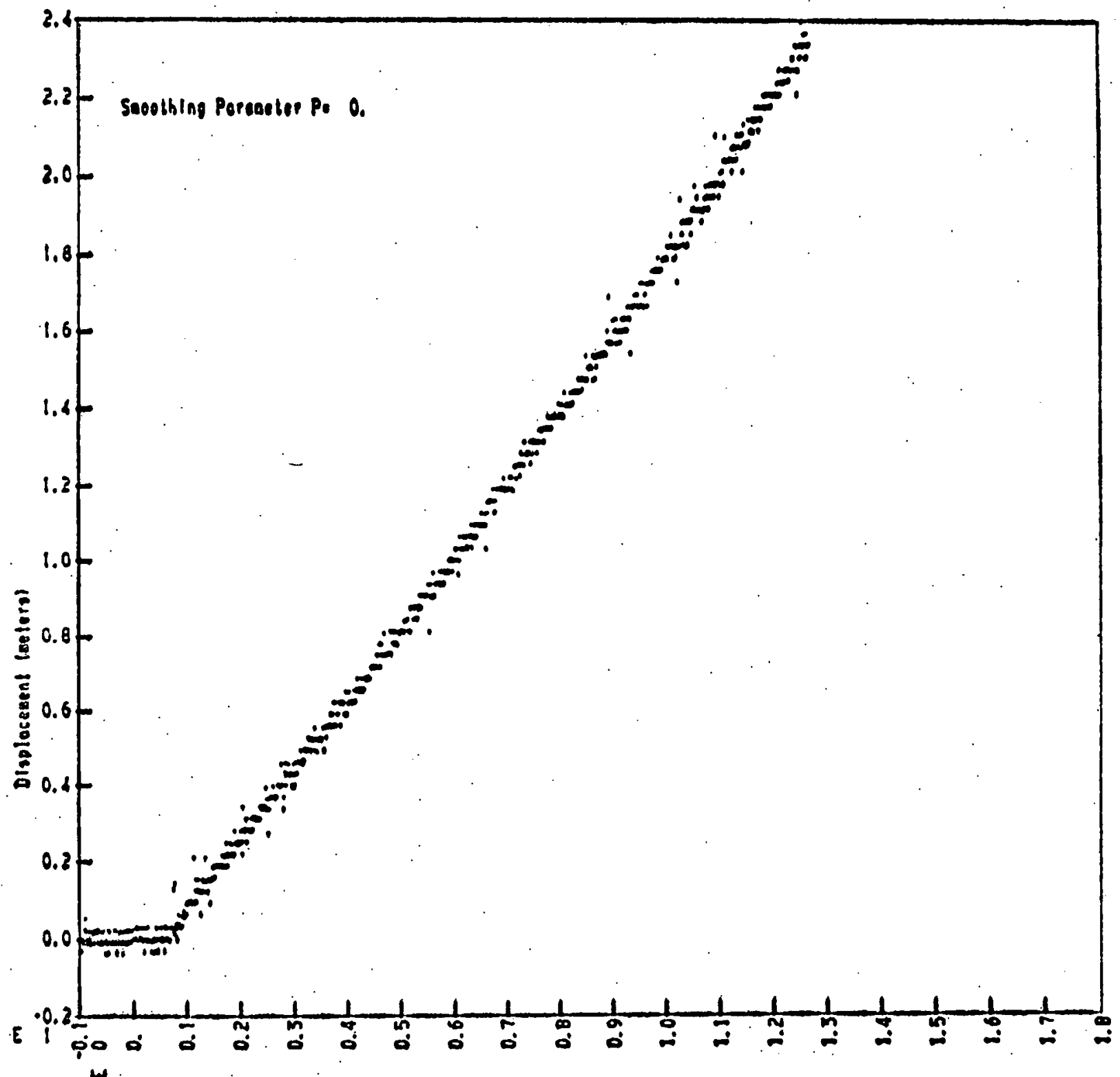

Plae 1s8e.)

FIGURE A-3.

Vertleal Displocement Target 3

$-20-$ 


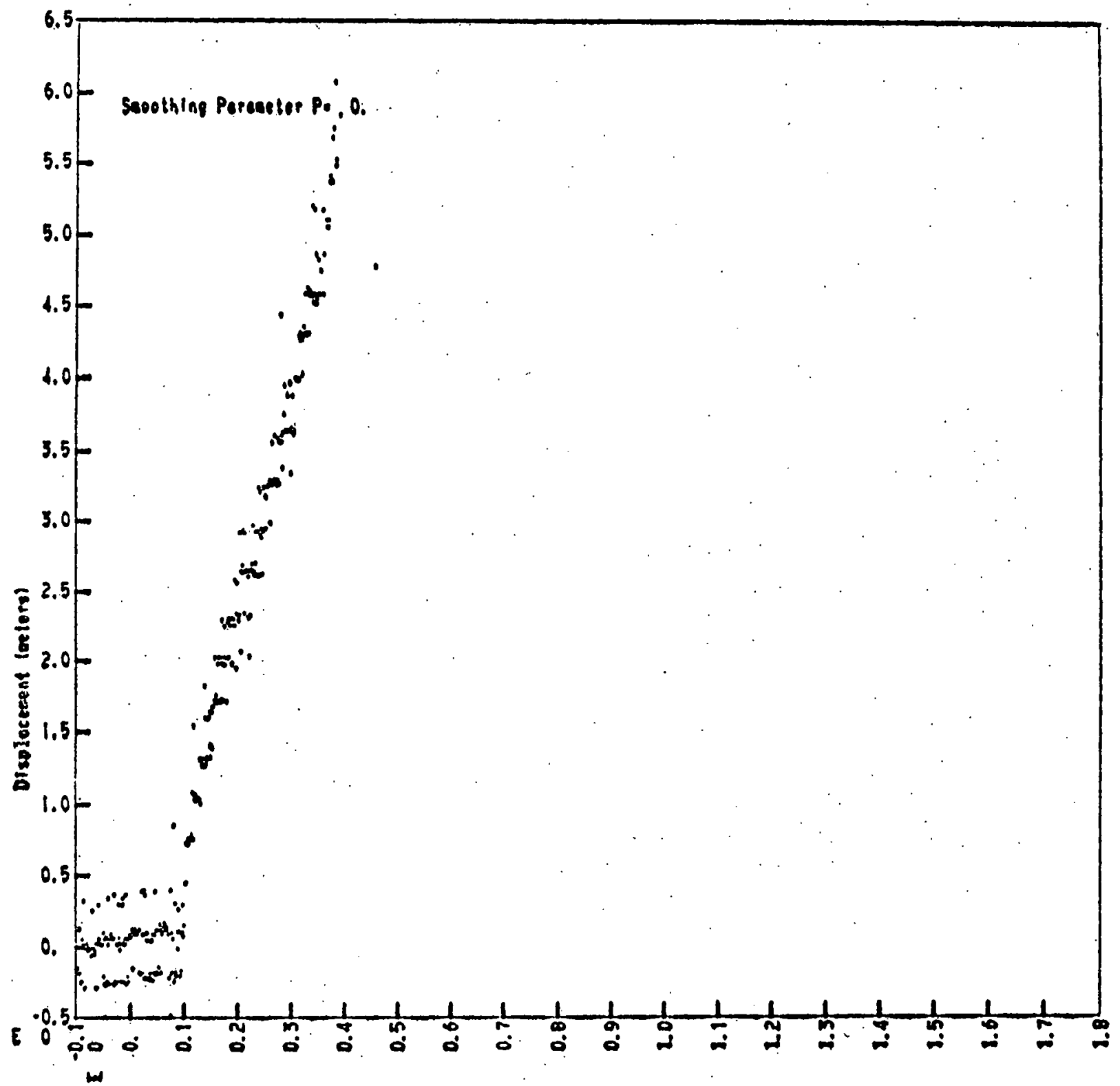

Plase loes.l

FIGURE A-4

Vertical Displocement Tapget \&

$-21-$ 


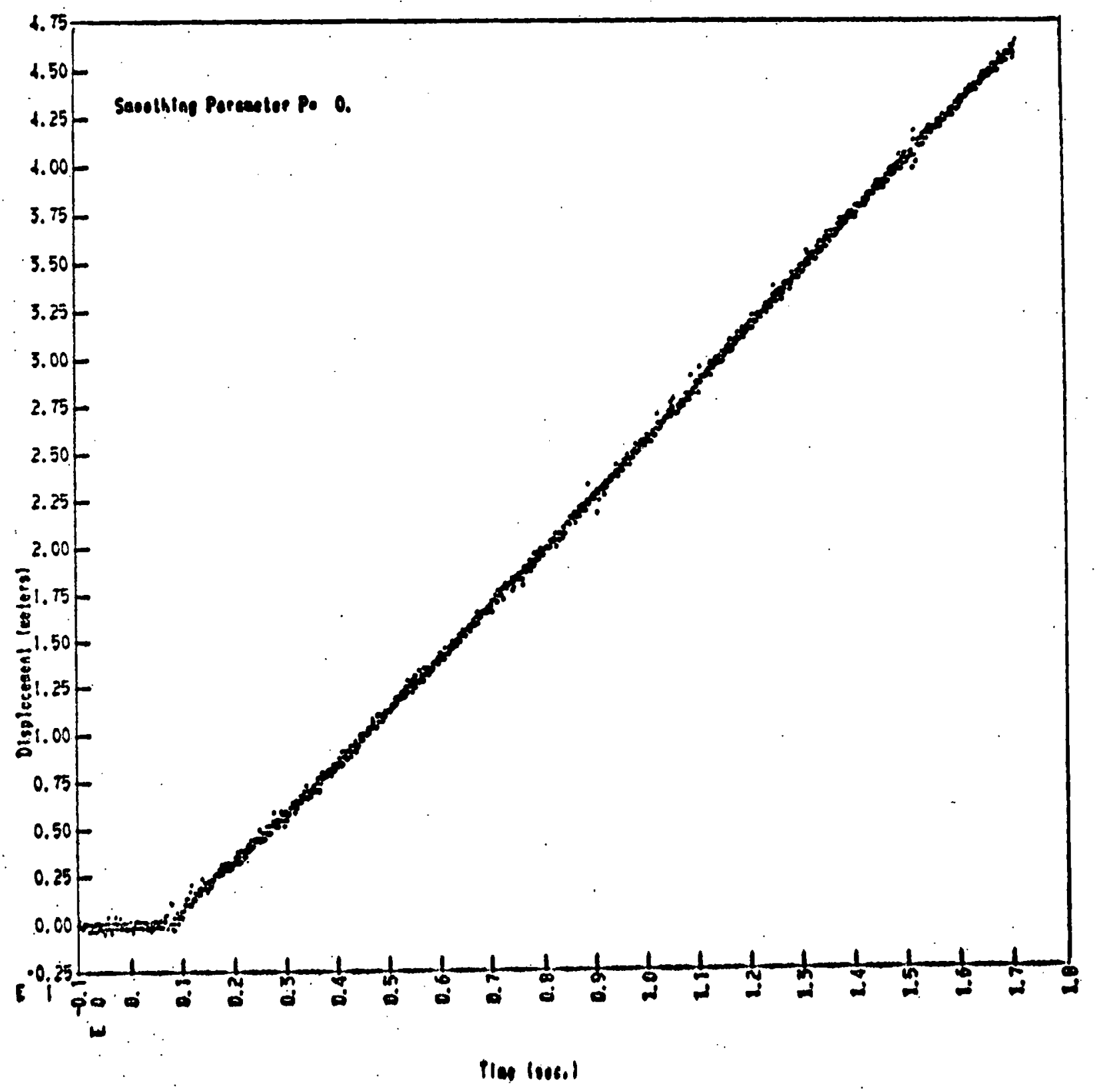

FIGURE A-5

Vertical Displacement Target. 5

$-22-$ 


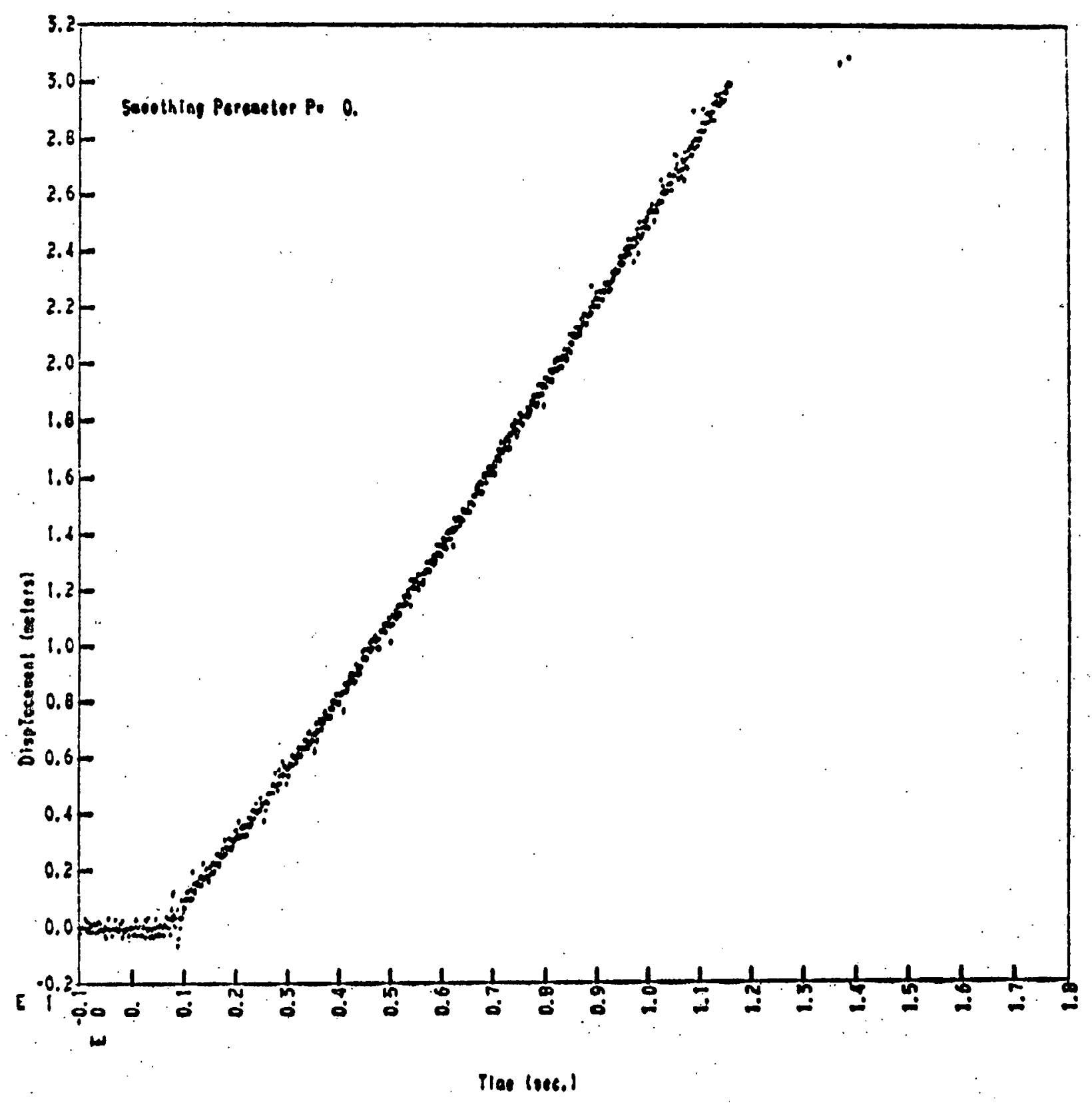

FIGURE A-6

Yertical Displecement Target 6

$-23-$ 


$$
E
$$




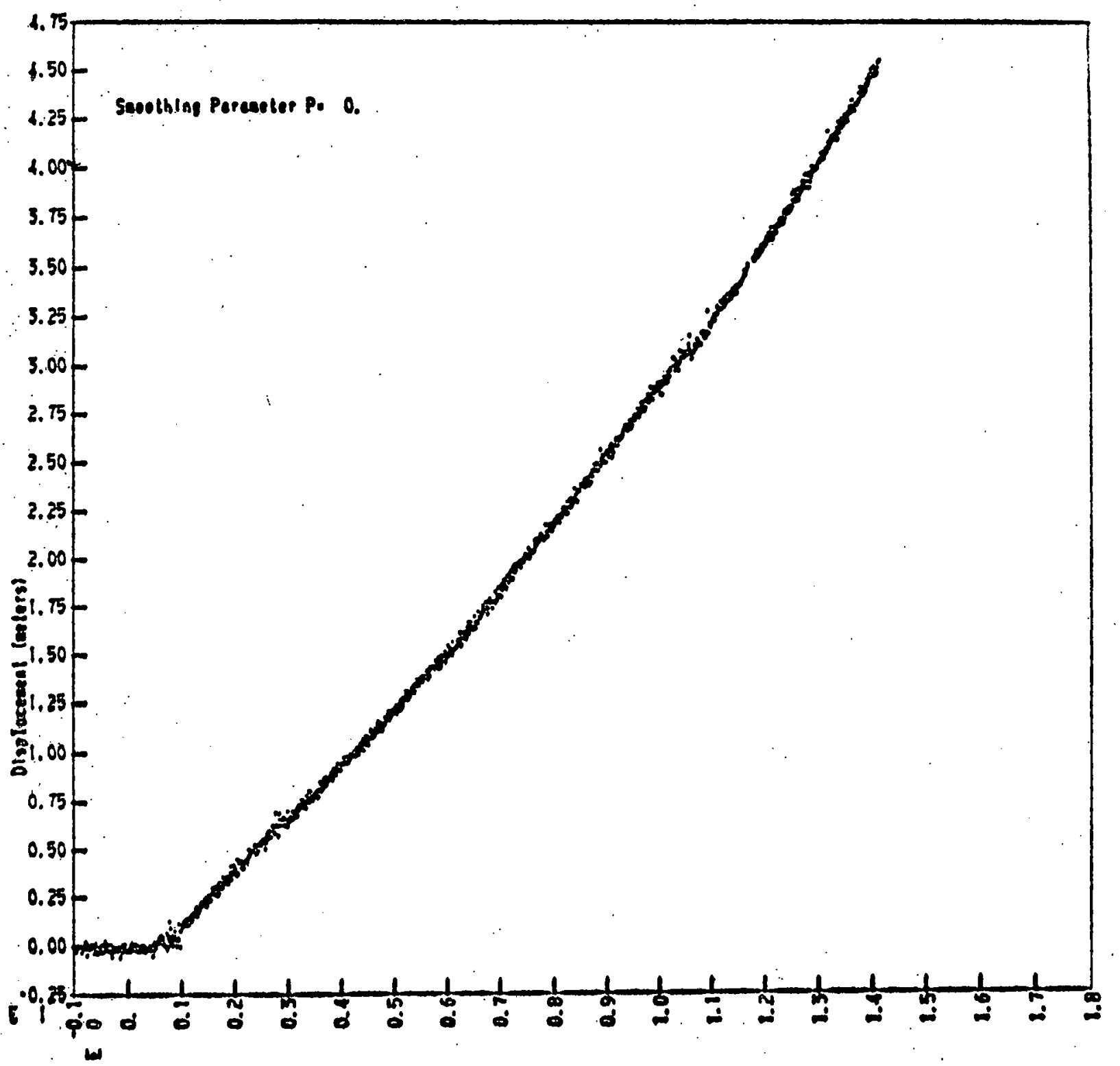

Pien loce.)

FIGURE A-8

Yertical Displocement Target 8

$-25-$ 


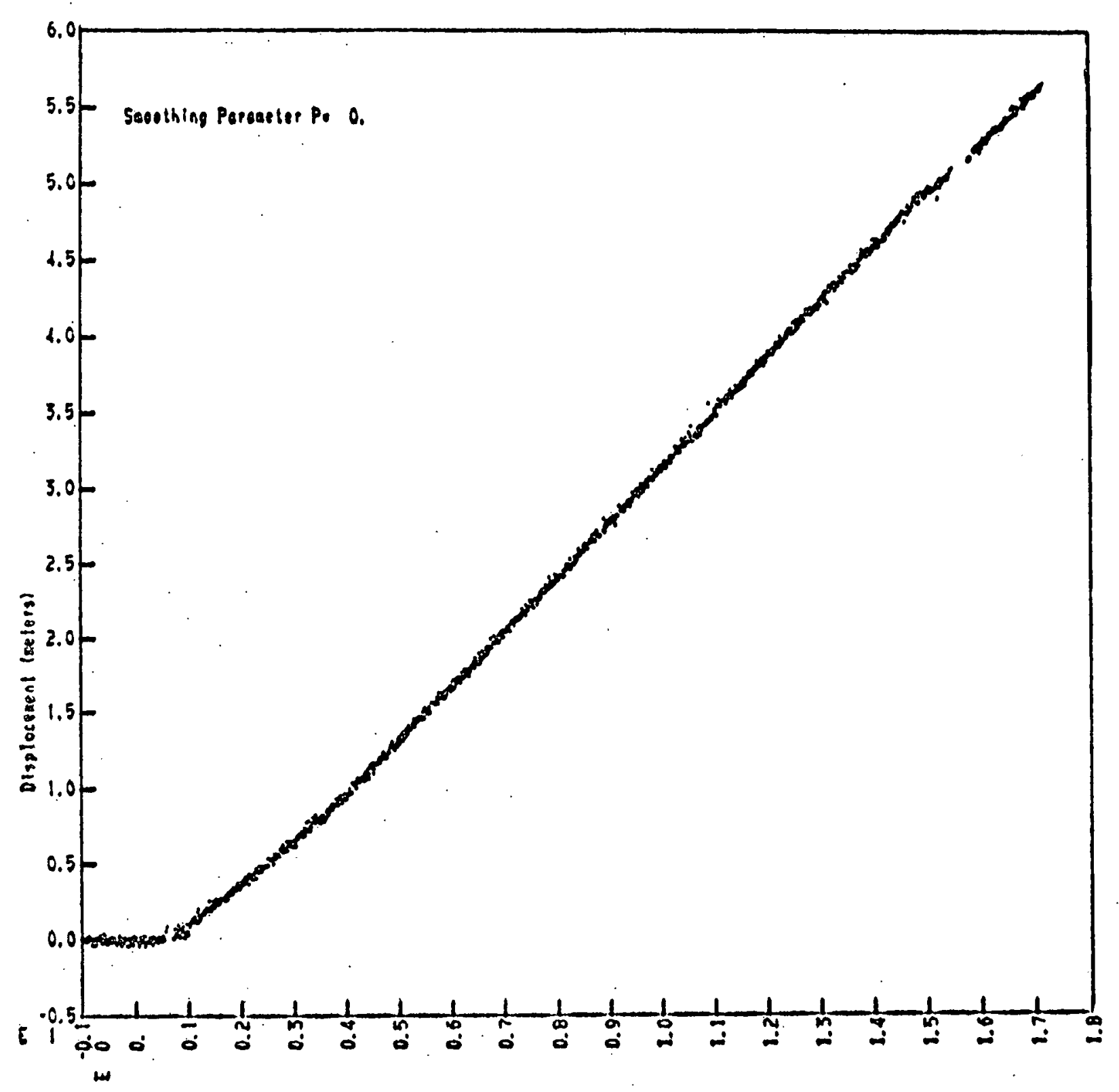

Tlee losc.)

FIGURE A-9

Vertical Displacement Torget $\theta$

$-26-$ 


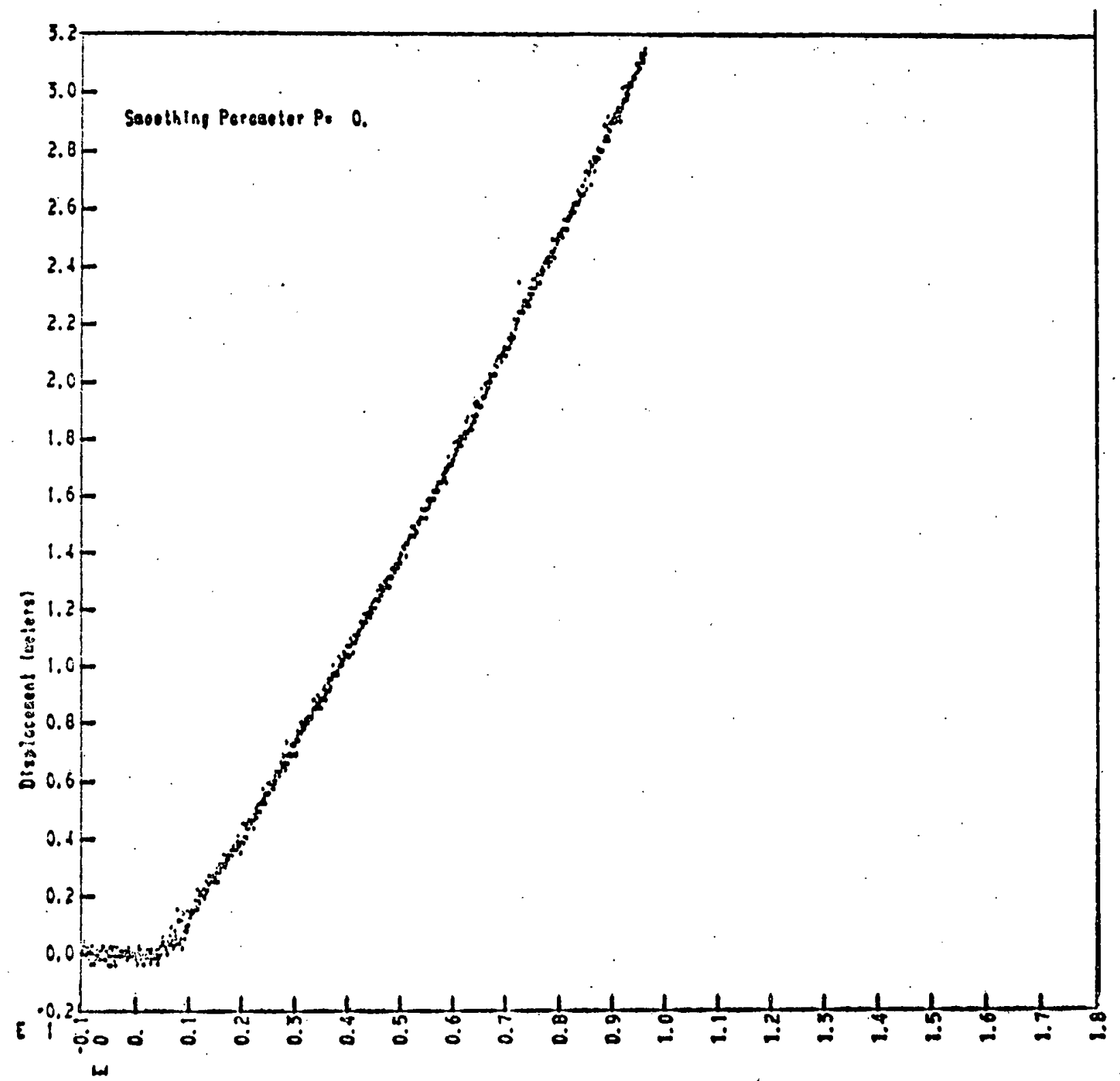

flo lee.)

FIGURE A-10

Vertical Displacement Target 10

$-27-$ 


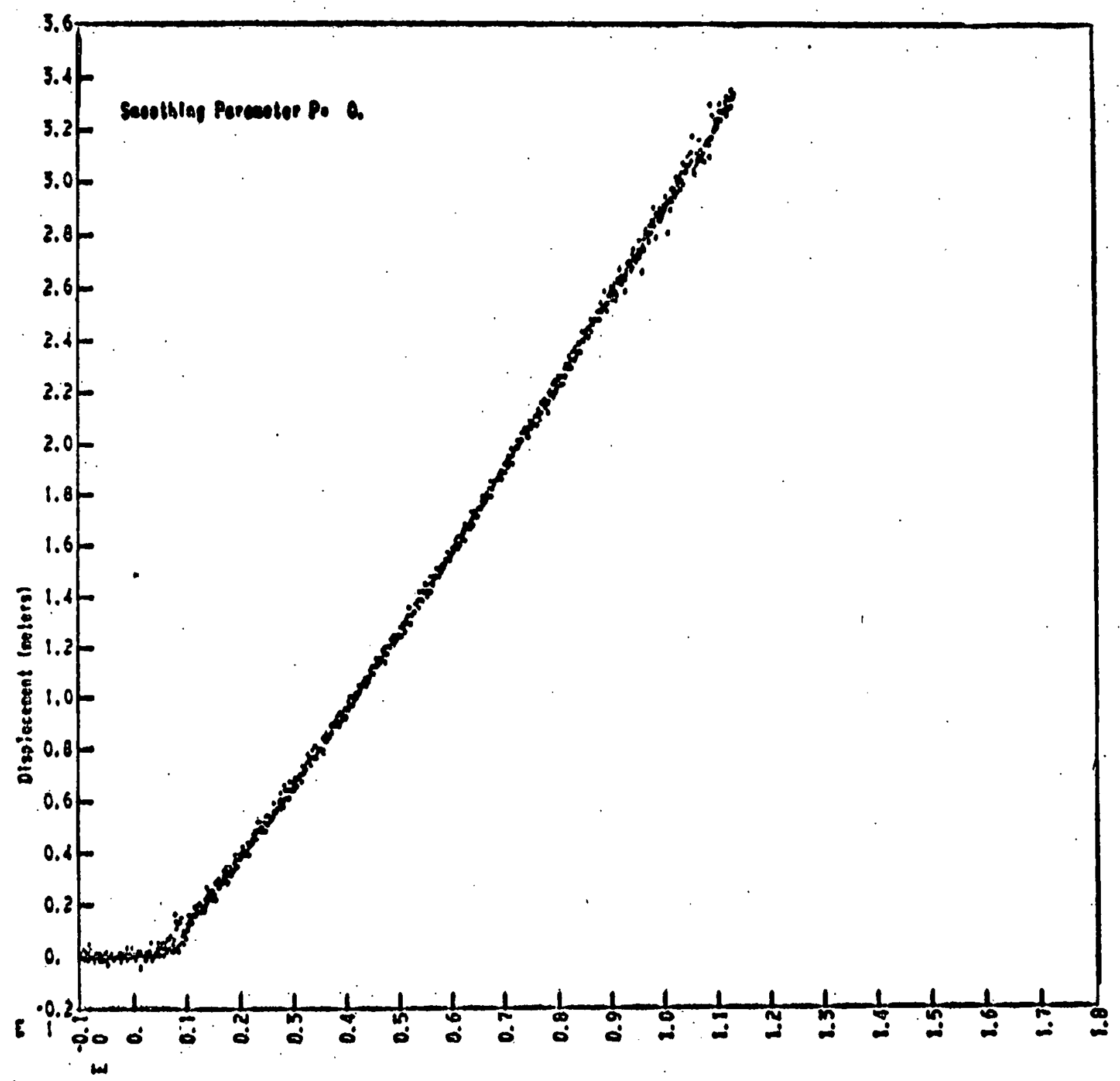

Pies (se6.)

FIGURE A-11

Vertical Displocement Torget 11

$-28-$ 


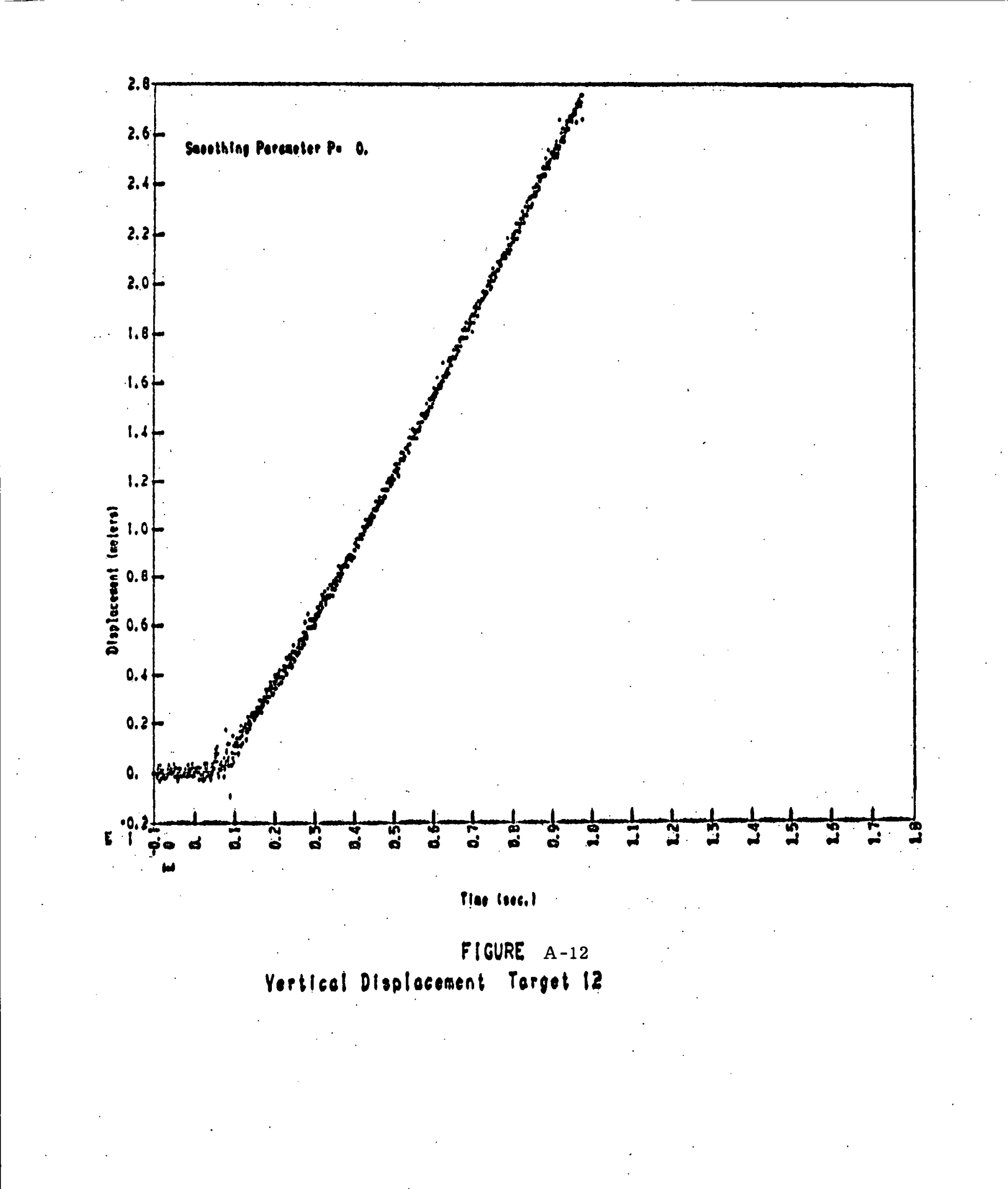




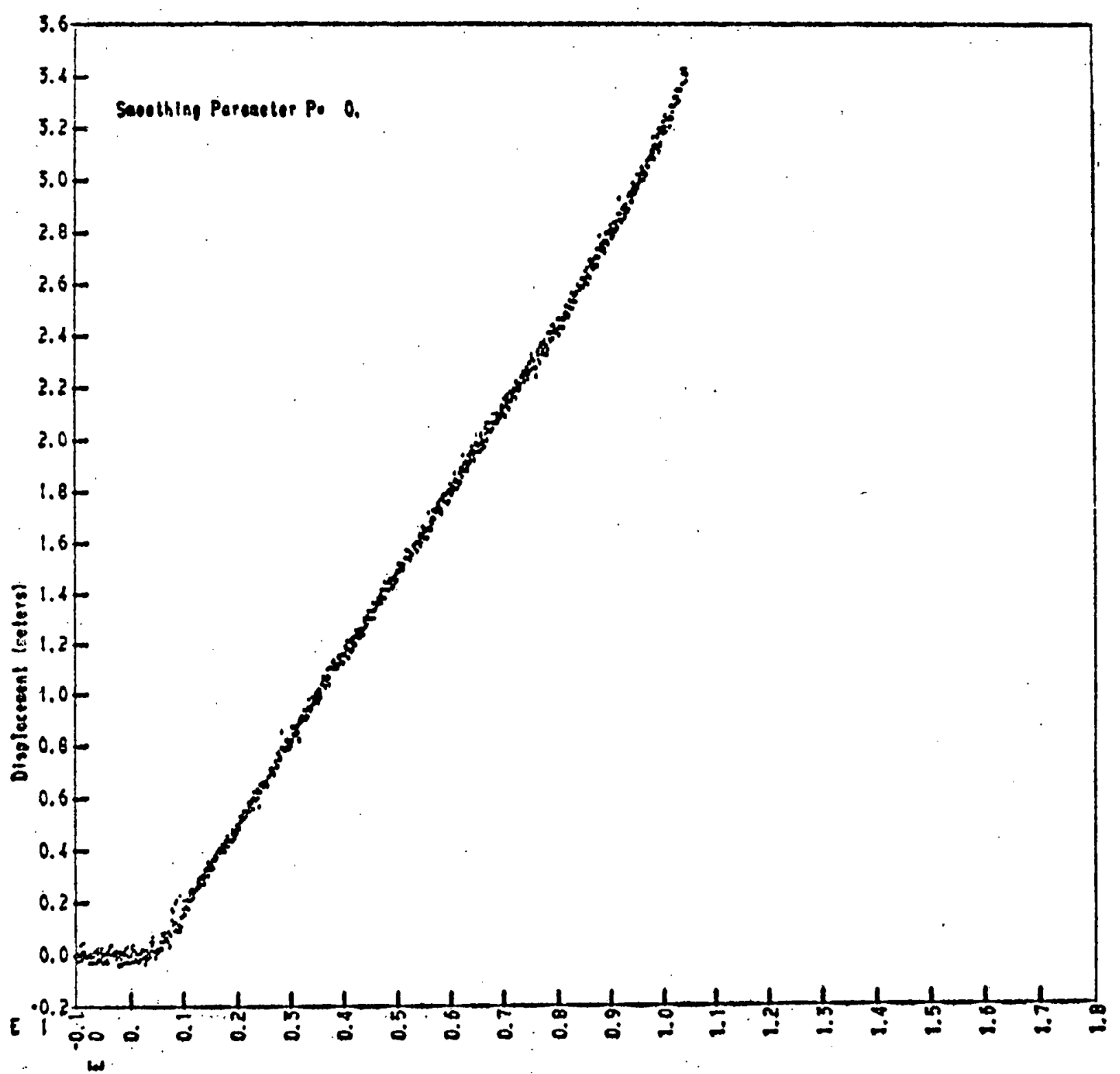

Ples lofe.

FIGURE A-13

Yertical Displacement Target 13

$-30-$ 


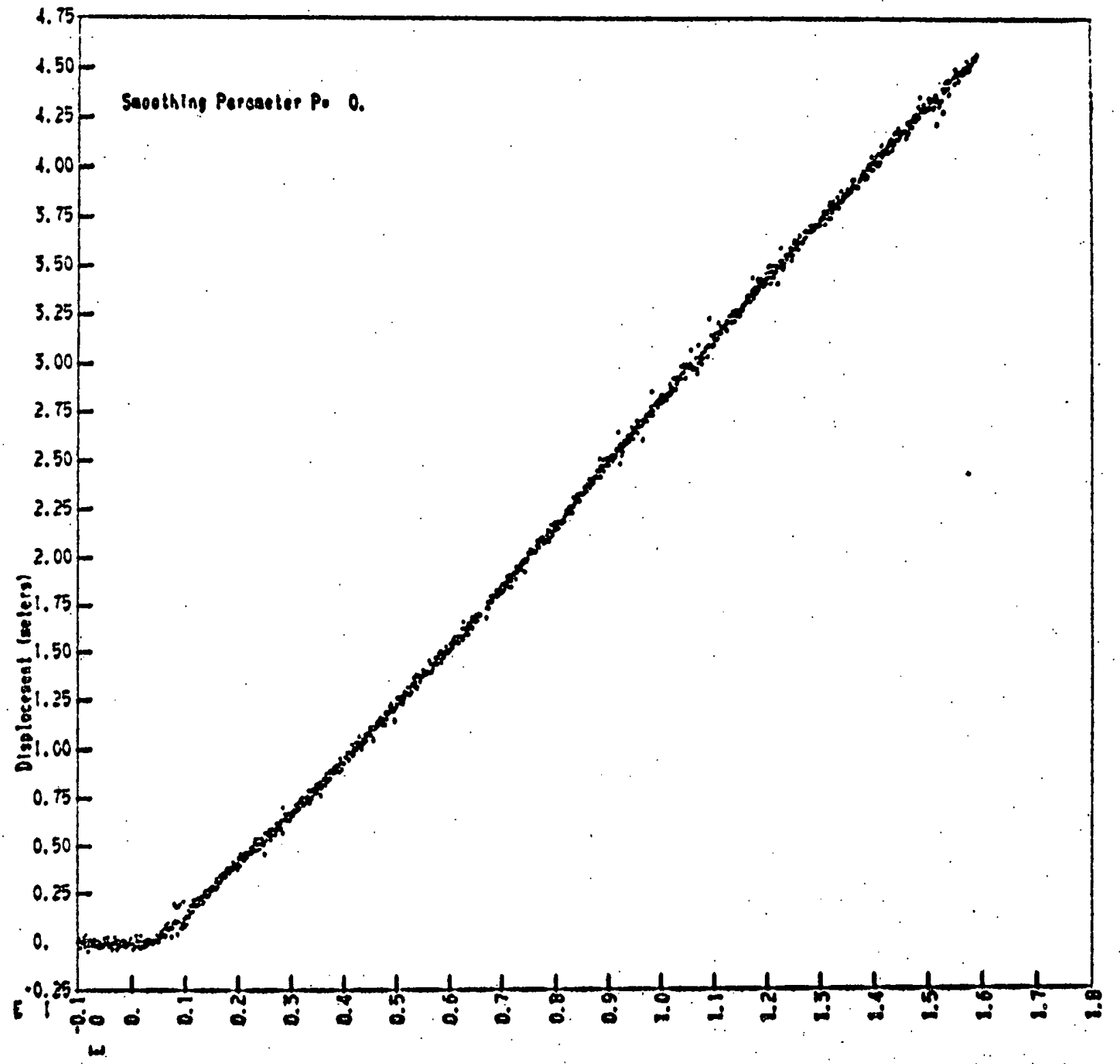

Plee 1oes.)

FIGURE A-14

Veptical Displacement Torgot if

$-31-$ 


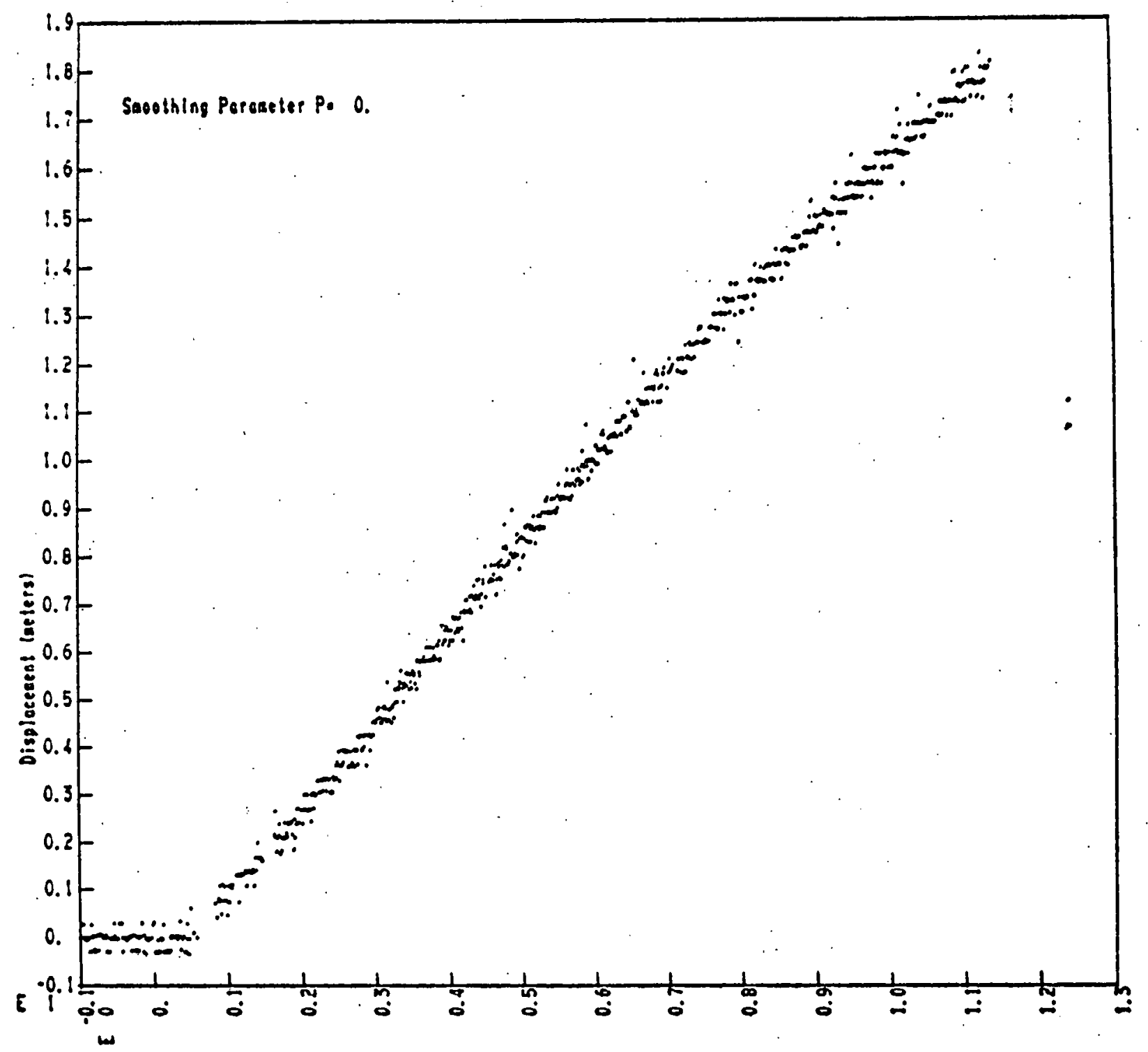

Plae (ses.)

FIGURE A-1B

Vertical Displacement Torget 15

$-32-$ 


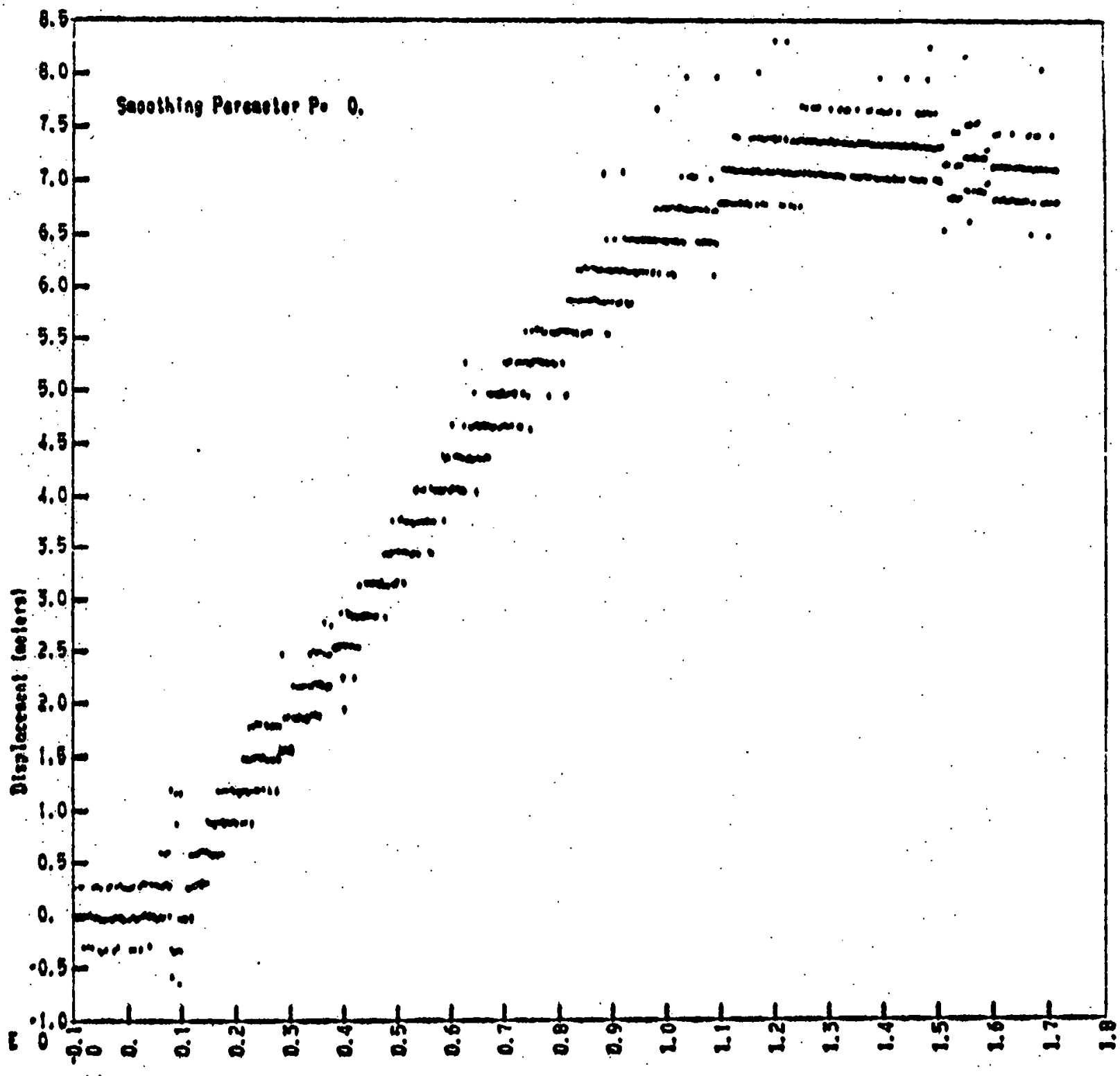

Pies looe.)

F I.GURE A-16

Vertical Displecement Target 16

-33- 


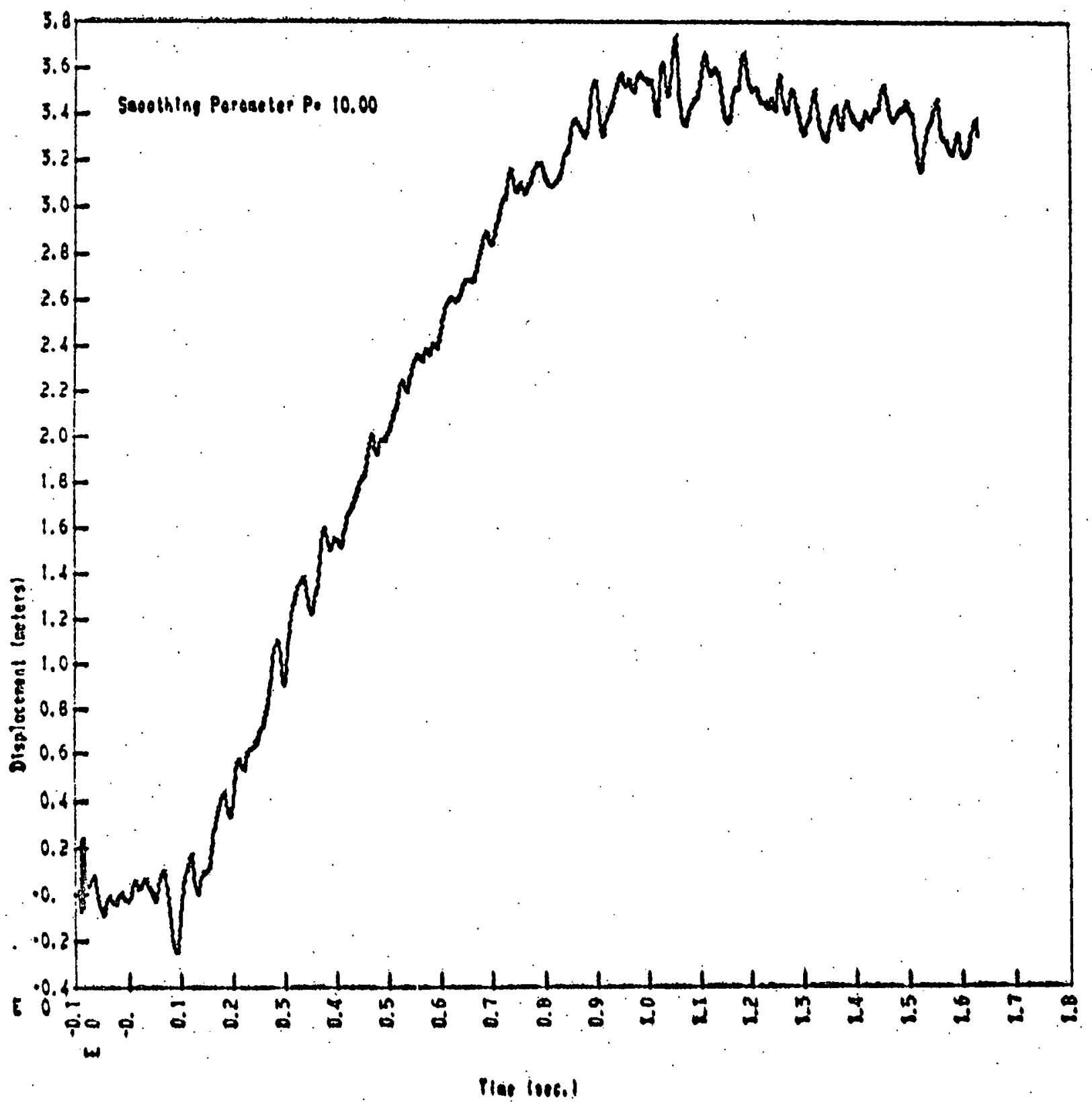

FIGURE A-17

Verflcal Dlsplocoment Target 1

$-34-$ 


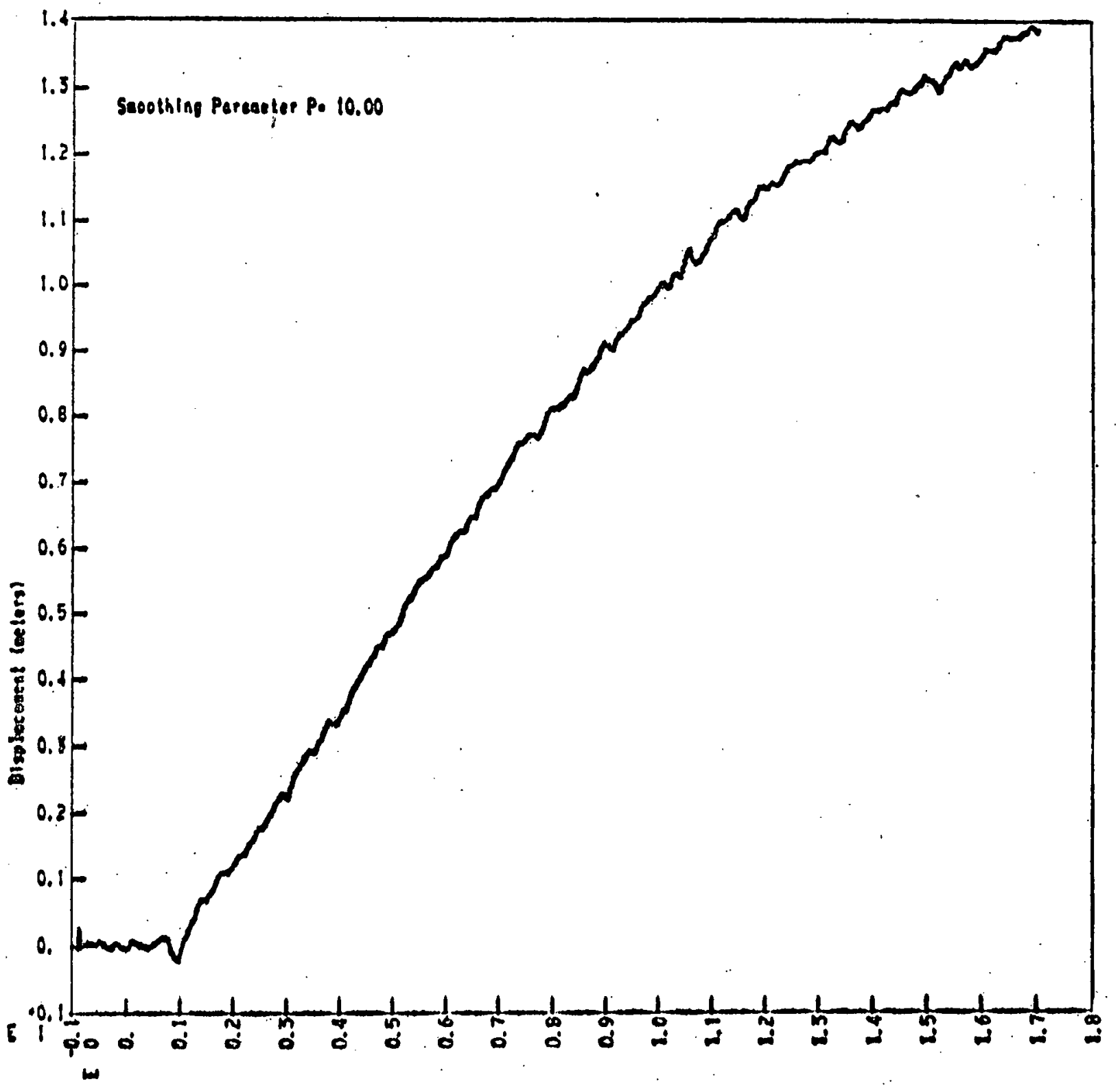

rees loce.

FIGURE A-18

Yertical Displocement Targot 2

-35- 


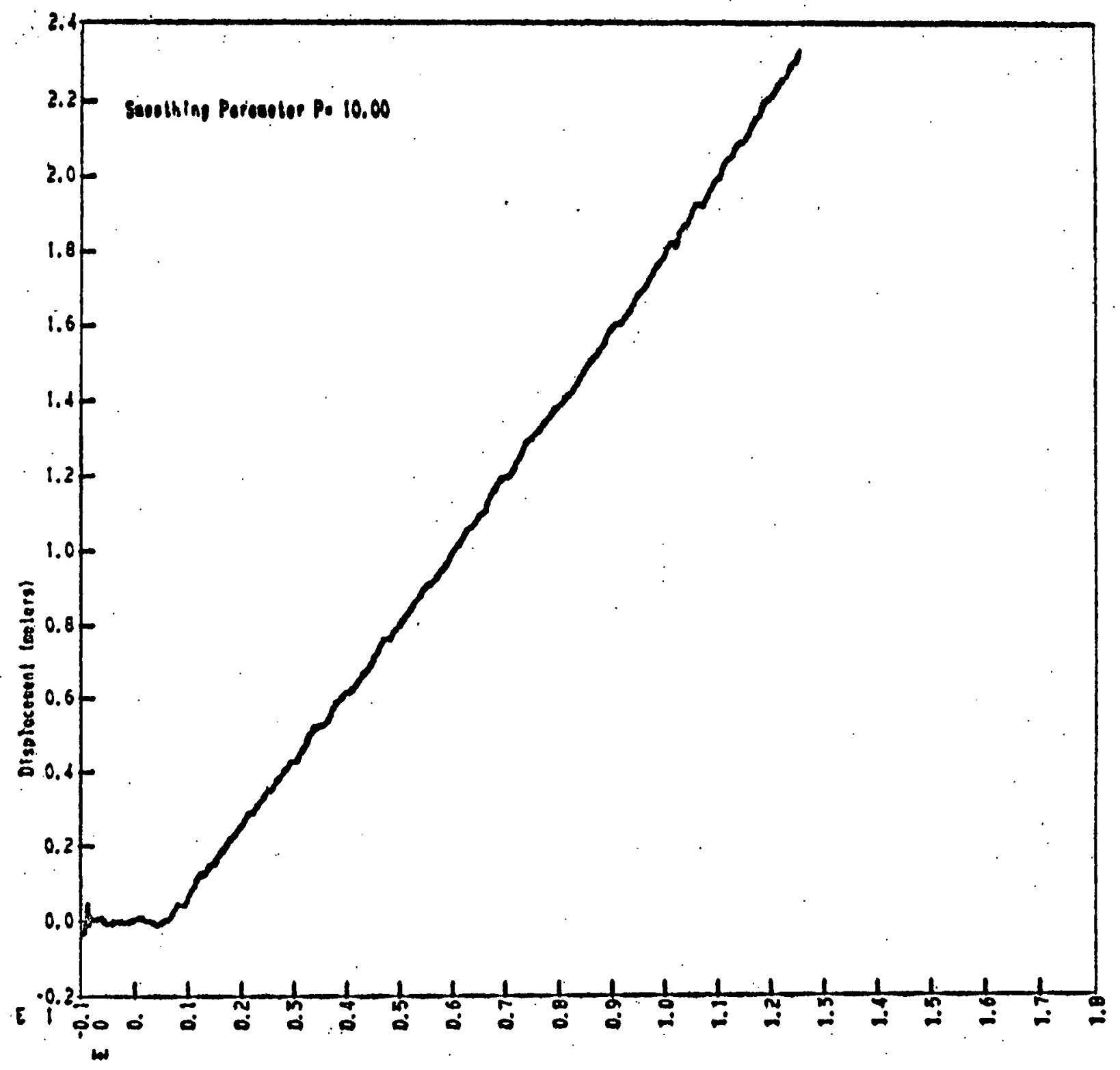

Ples (ses.)

FIGURE A-19

Yeptlcel Dloplocement Tapget 3

$-36-$ 


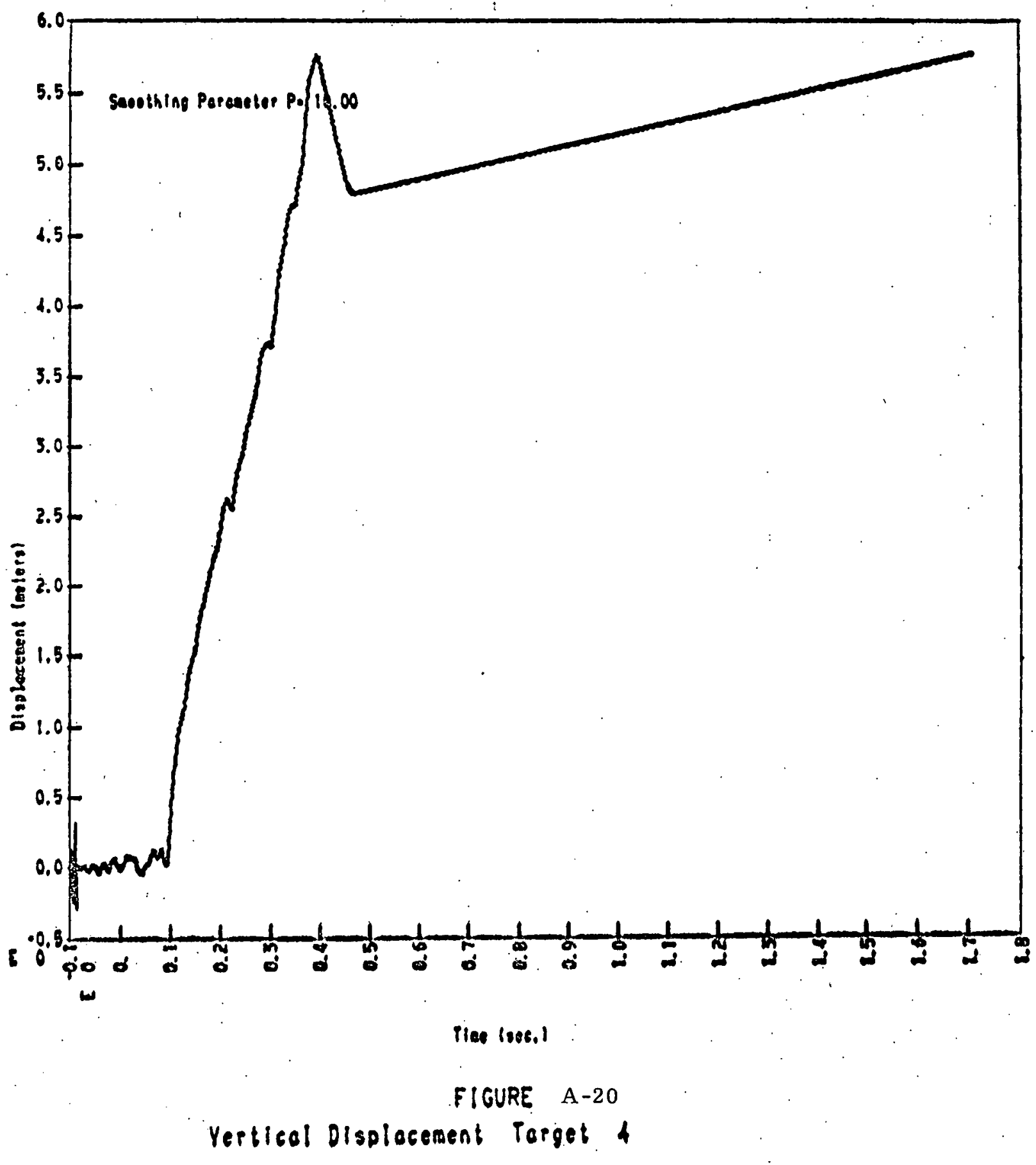

$-37-$ 


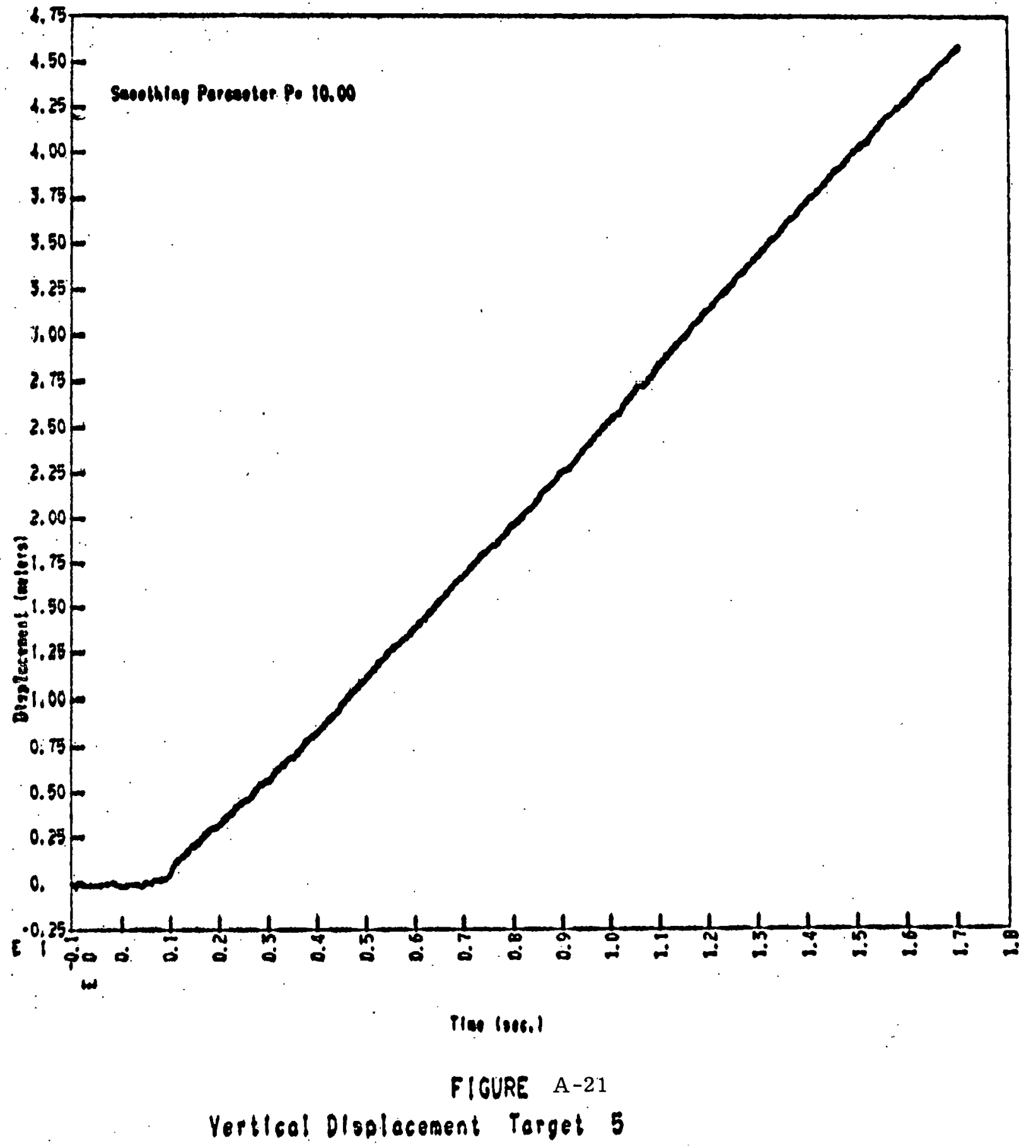

$-38-$ 


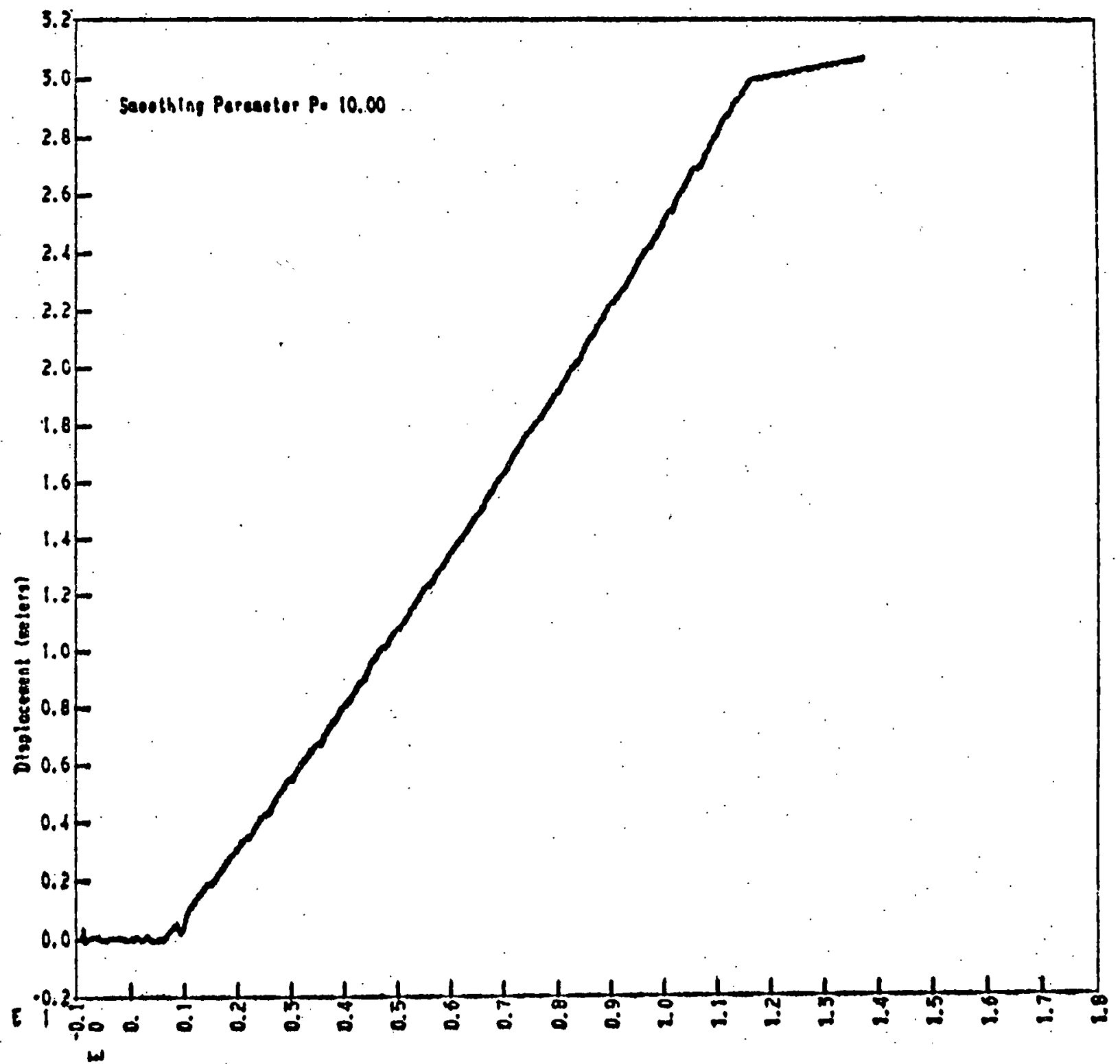

Than lines.

FIGURE A-22

Veptlcol Displacement Target 6

$-39-$ 


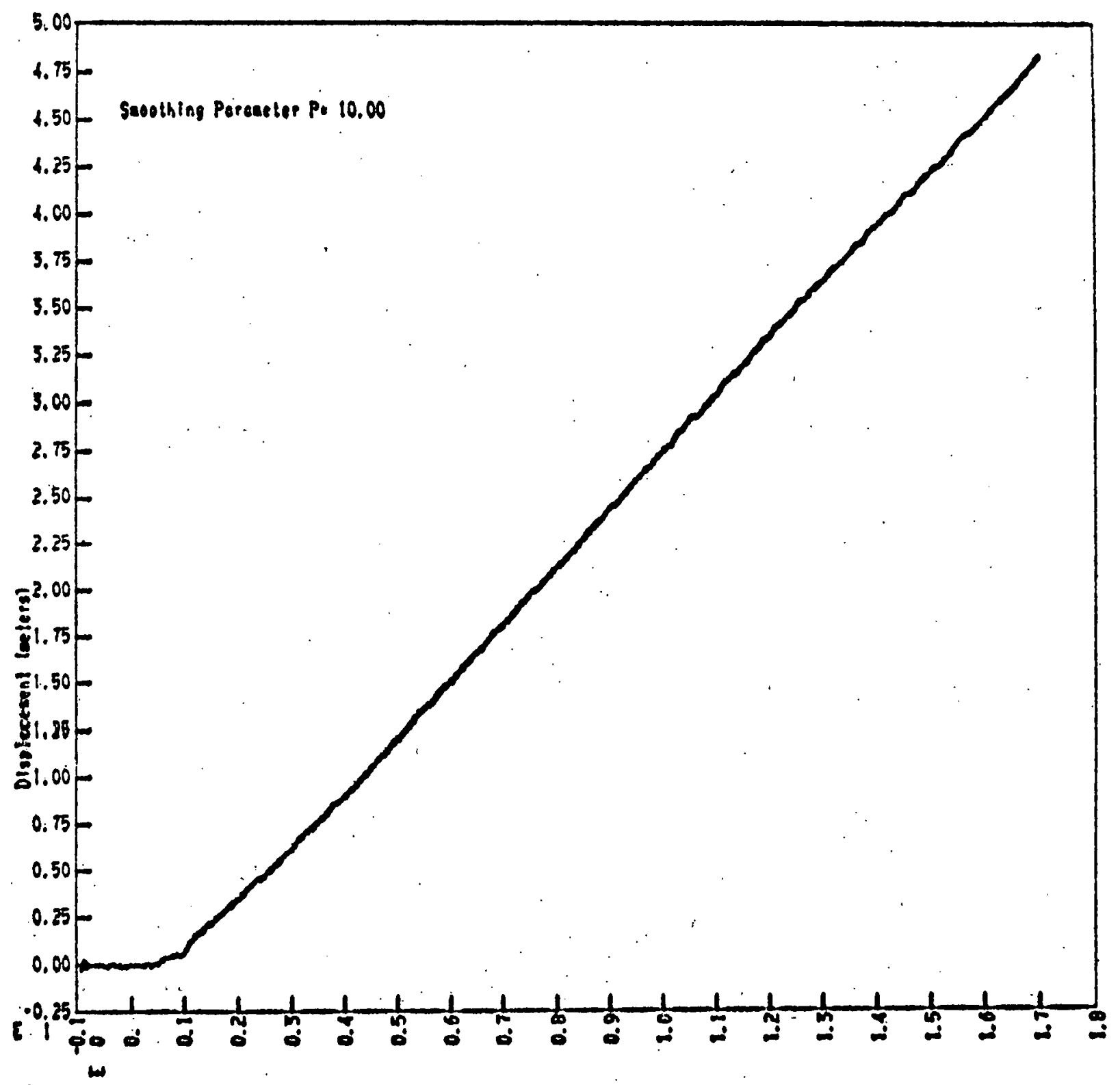

Plee besc.l

\section{F. GURE A-23}

Yertical Displocement Target? 


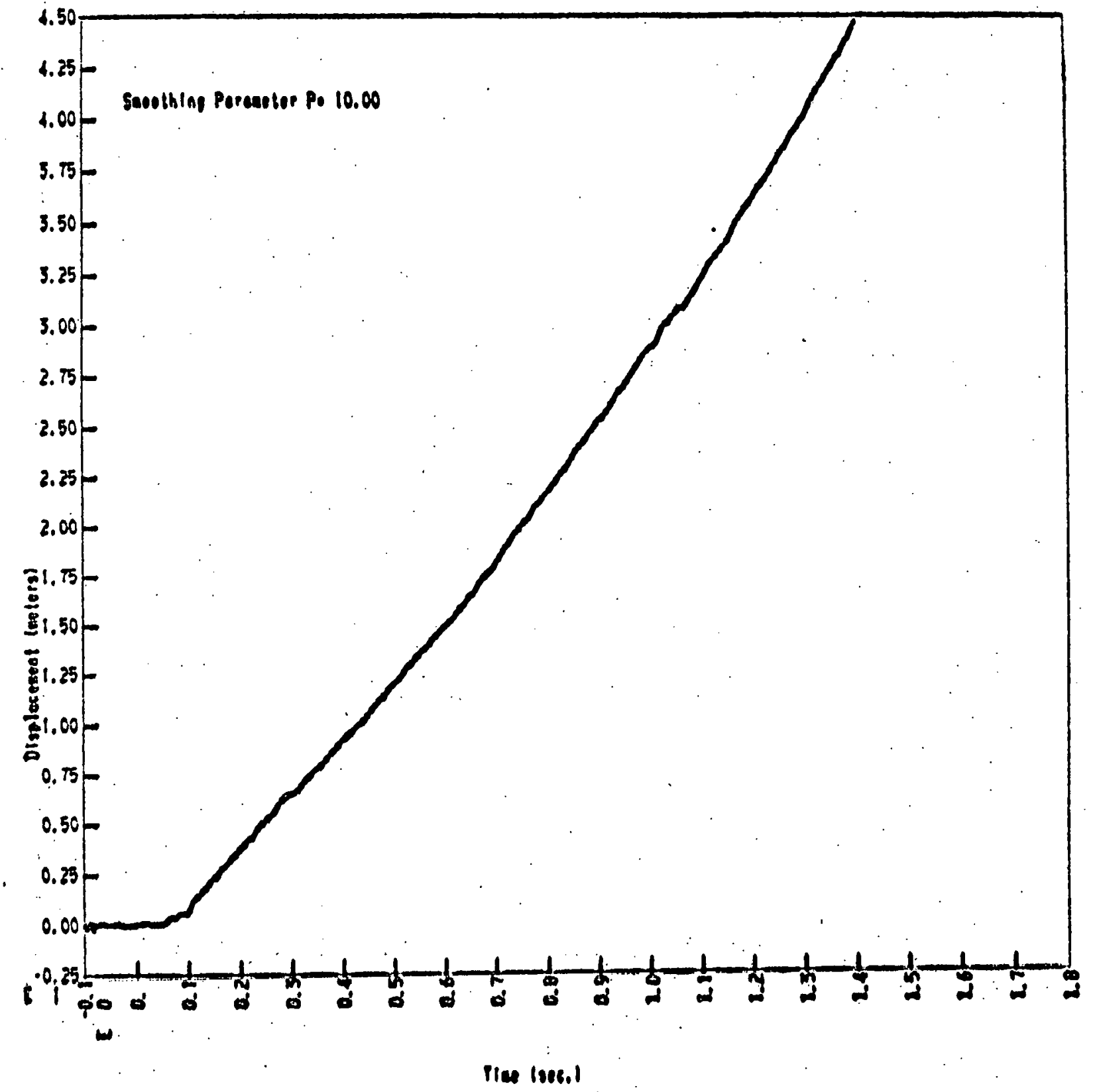

FIGURE A-24

Veptleol Displocement Topget 8

$-41-$ 


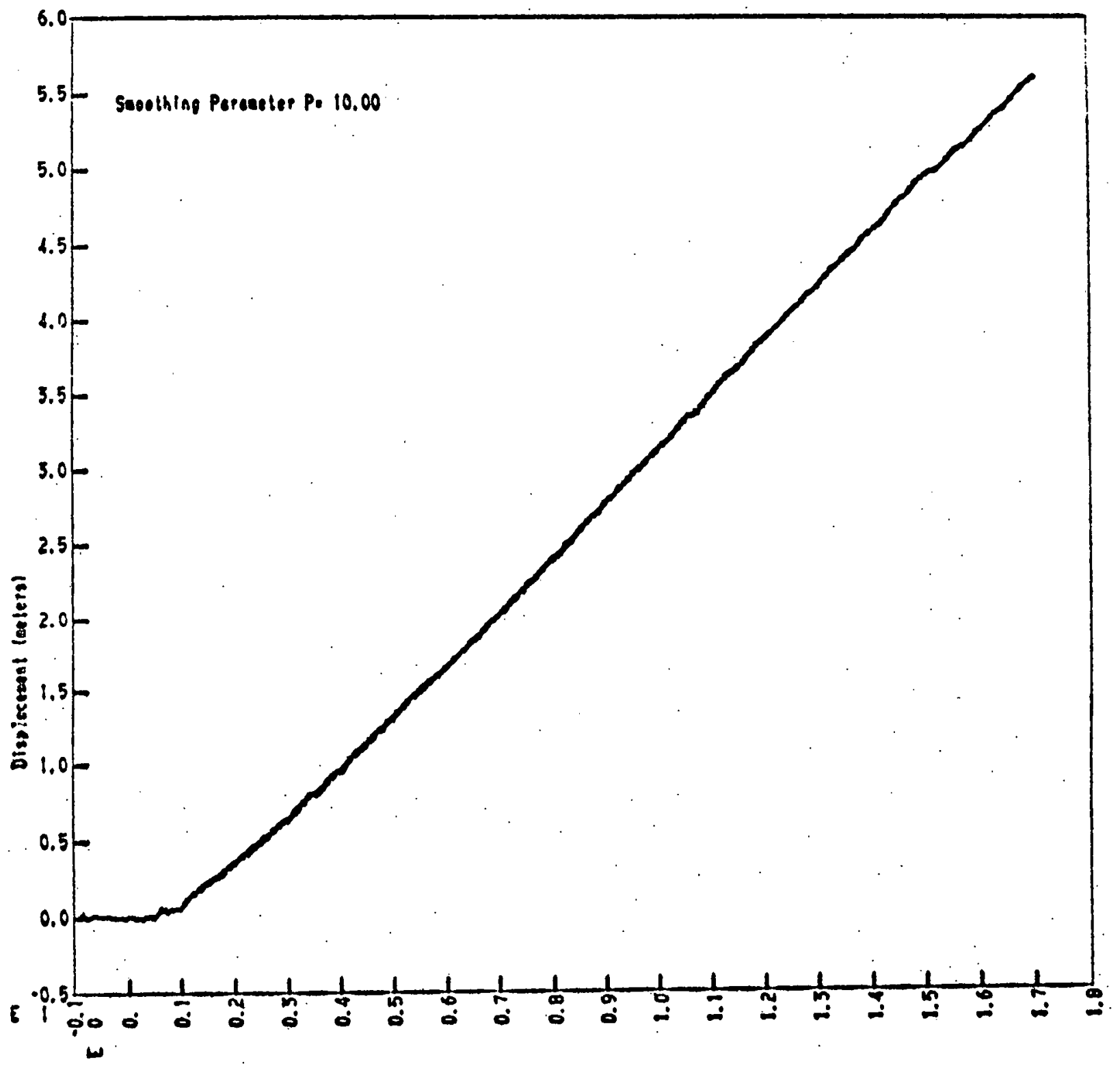

Plee 19e6.)

FIGURE A-25

Verticol Displacement Torget 9

$-42-$ 


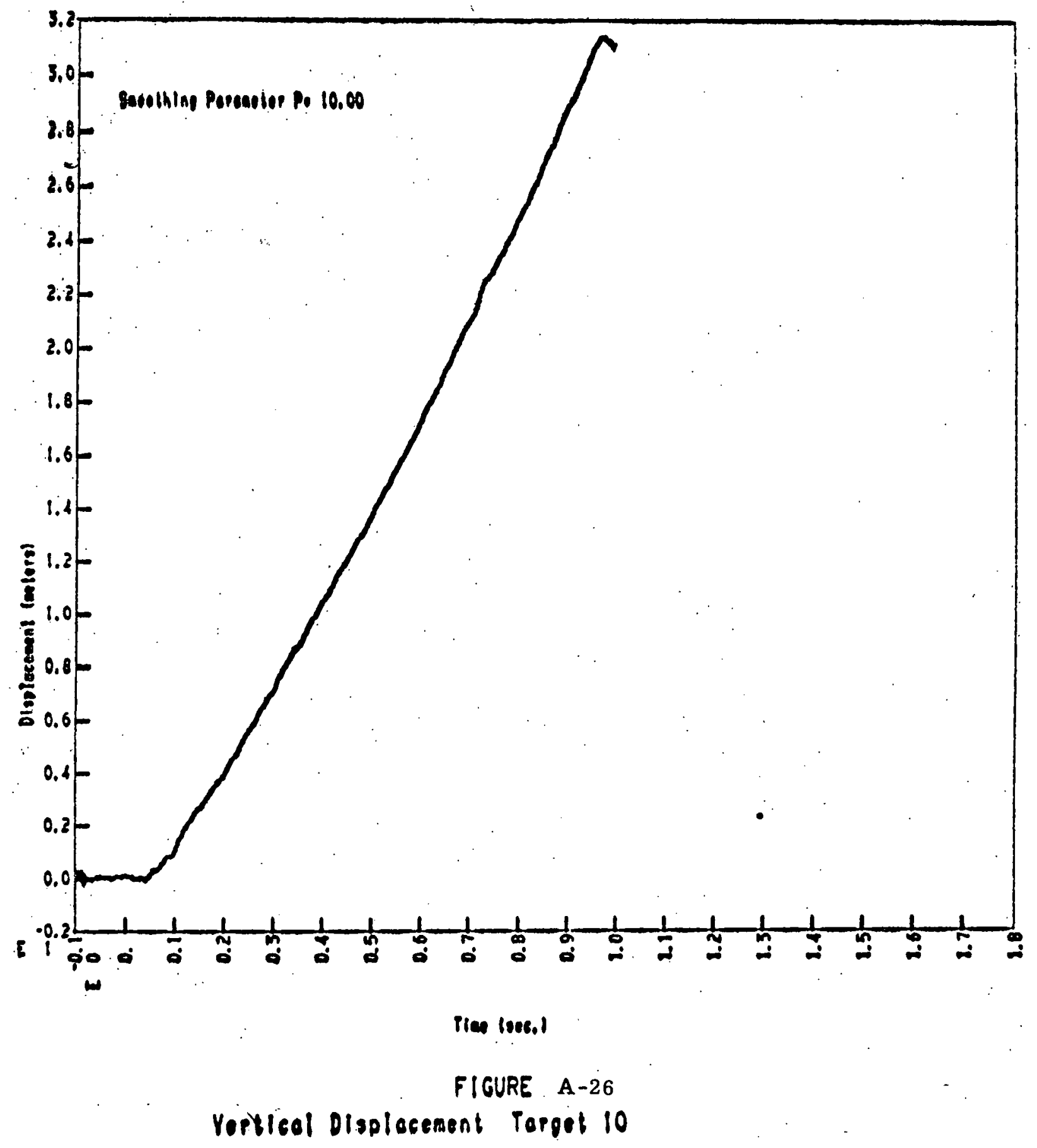

$-43-$ 


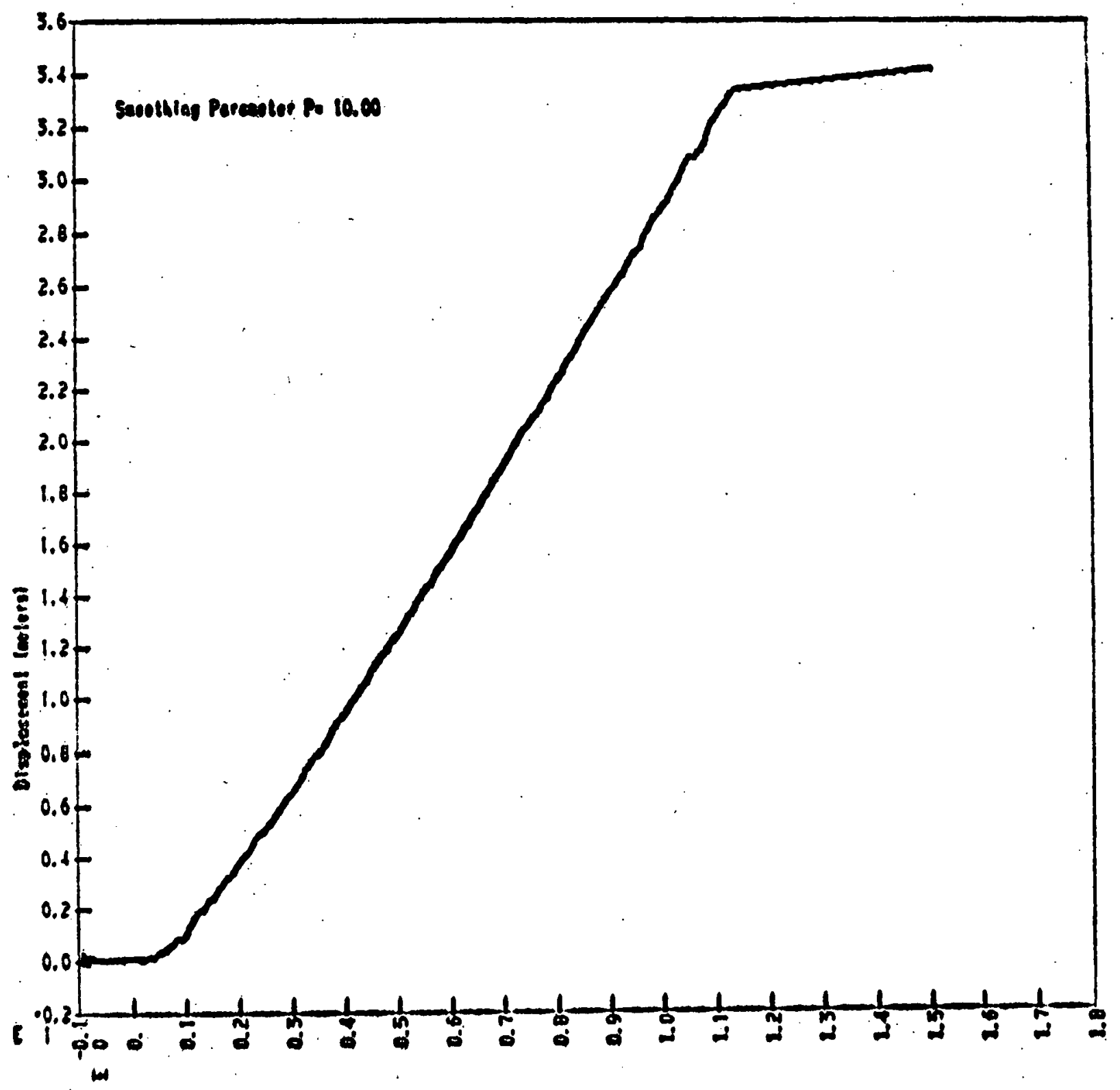

rise Reesel

FIGURE A-27

Vertlcal Displocement Target 11 


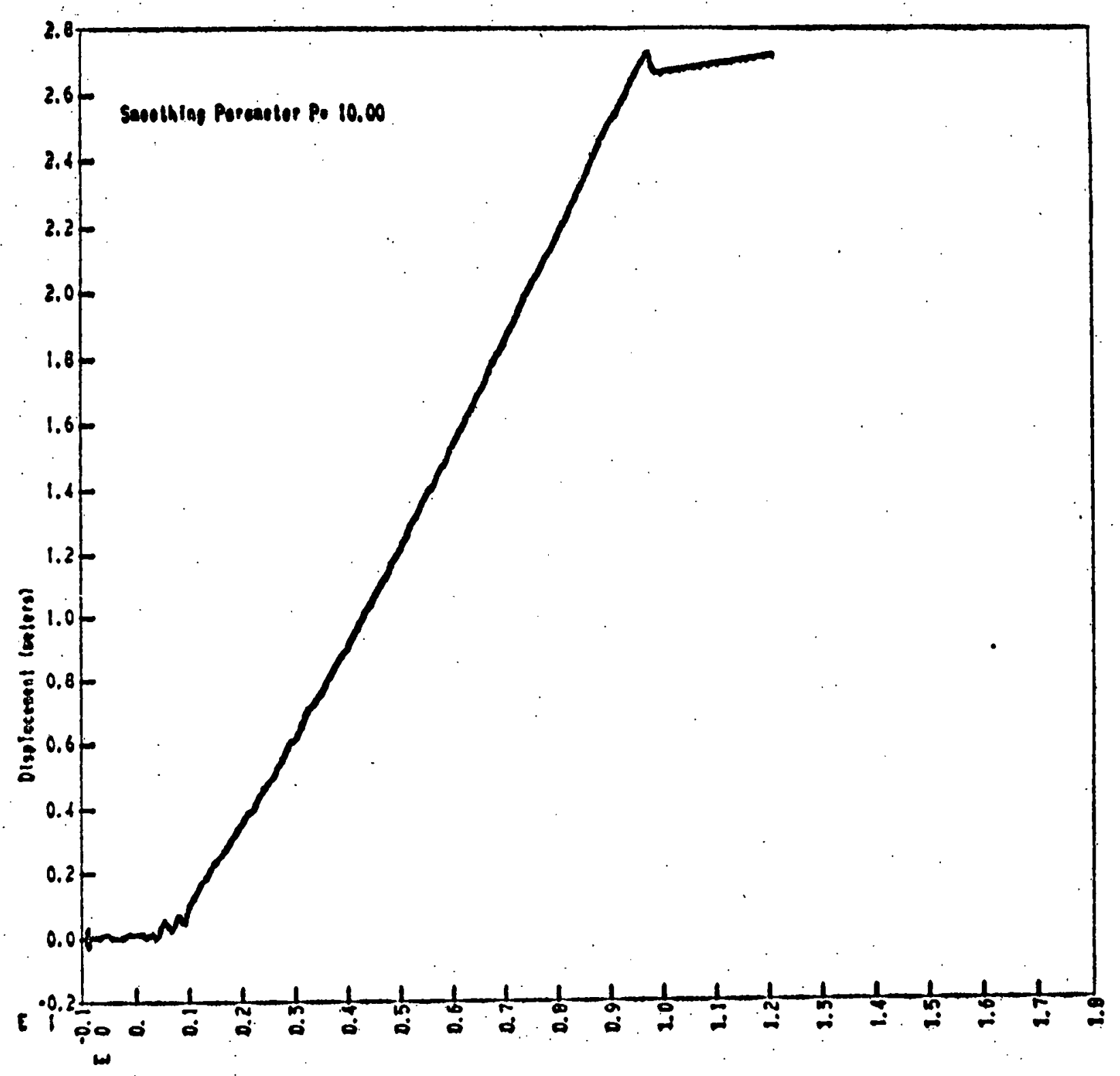

fles lock,

FIGURE A-28

Verticol Dlsplacement Torget 12 .

$-45-$ 


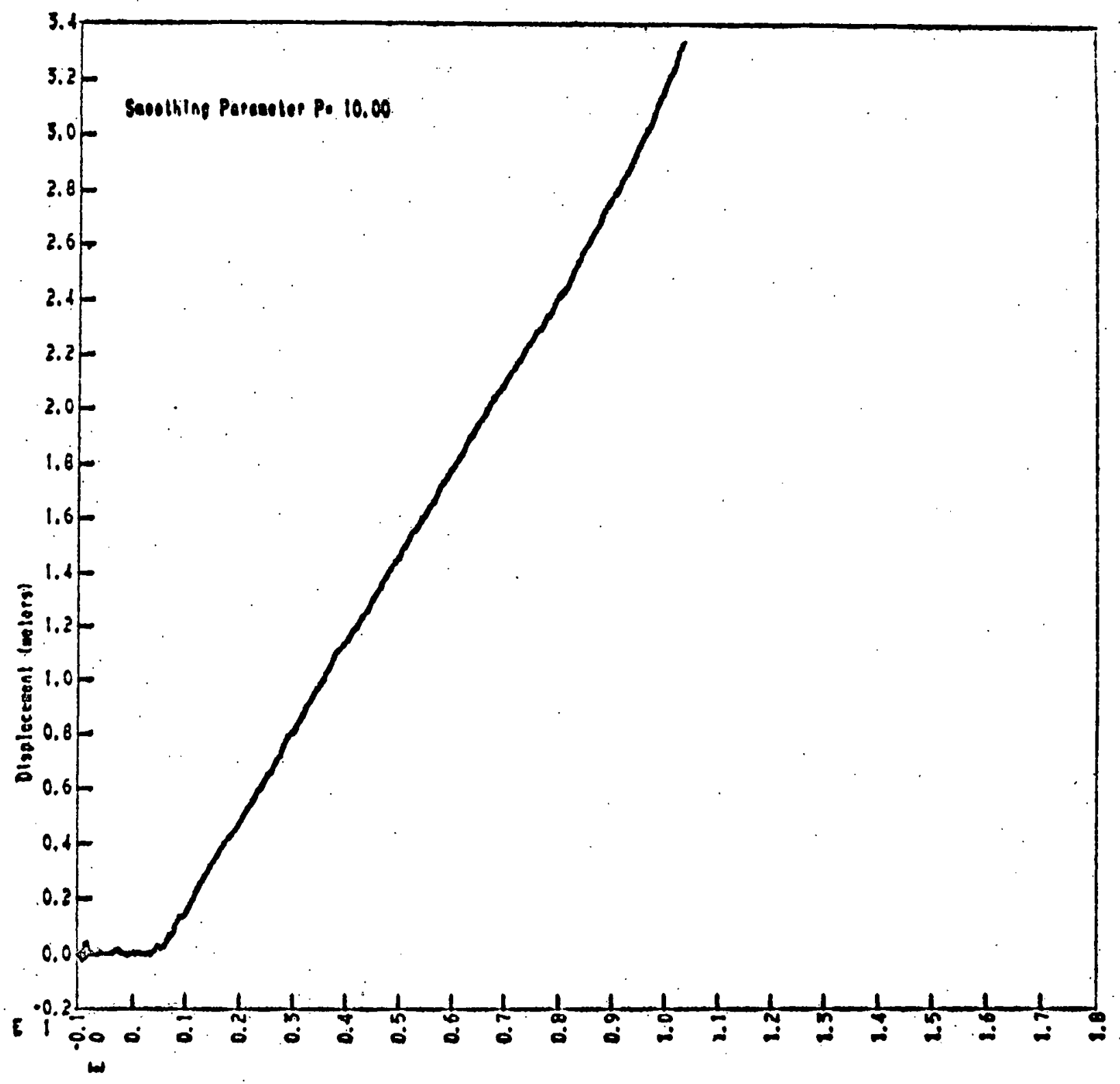

Tiee lses.)

FIGURE A-29

Vertleal Displecement Target 13

$-46-$ 


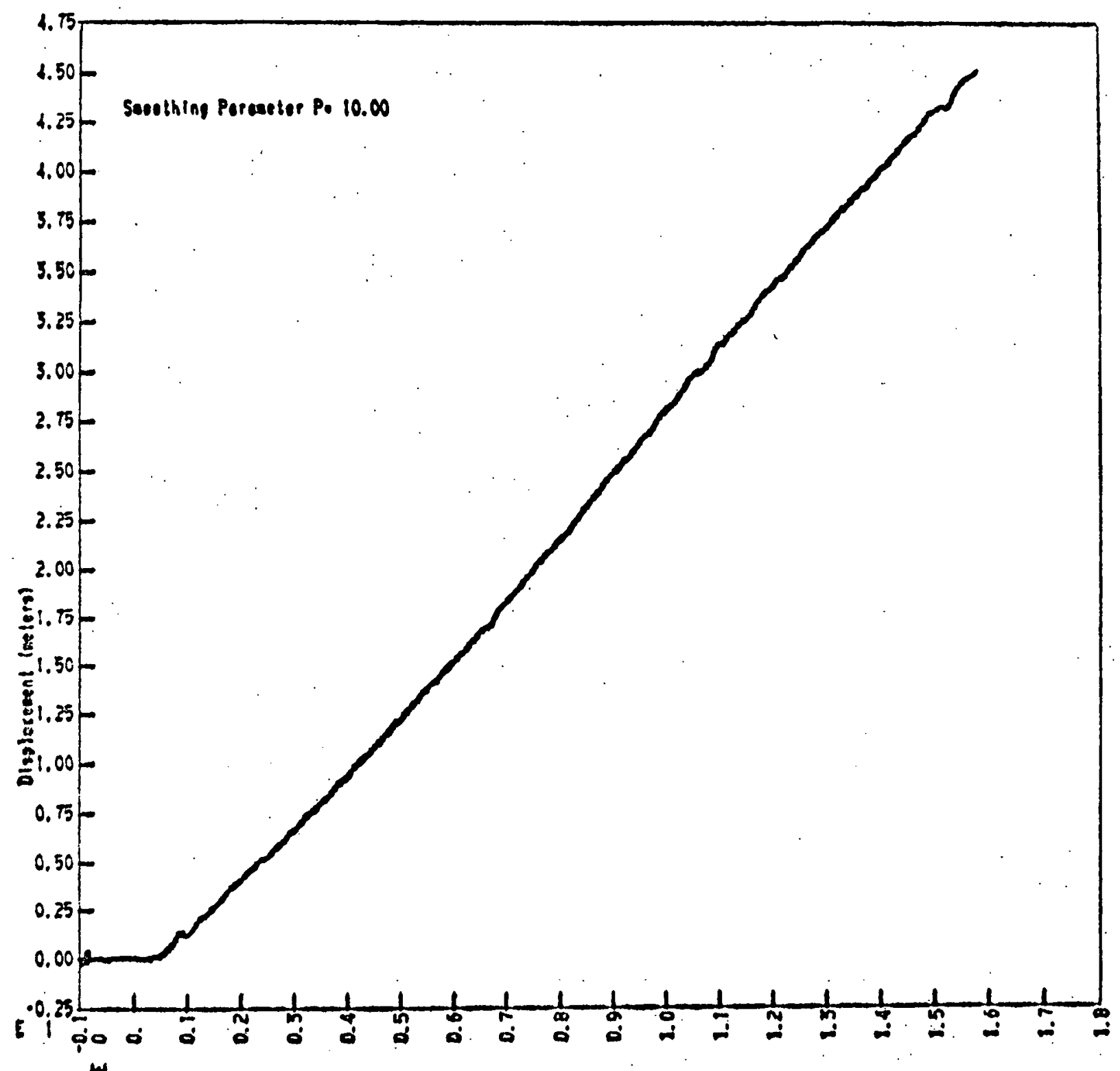

Plae loces

FIGURE A-30

Yerticol Disolocement Torgot If

-47- 


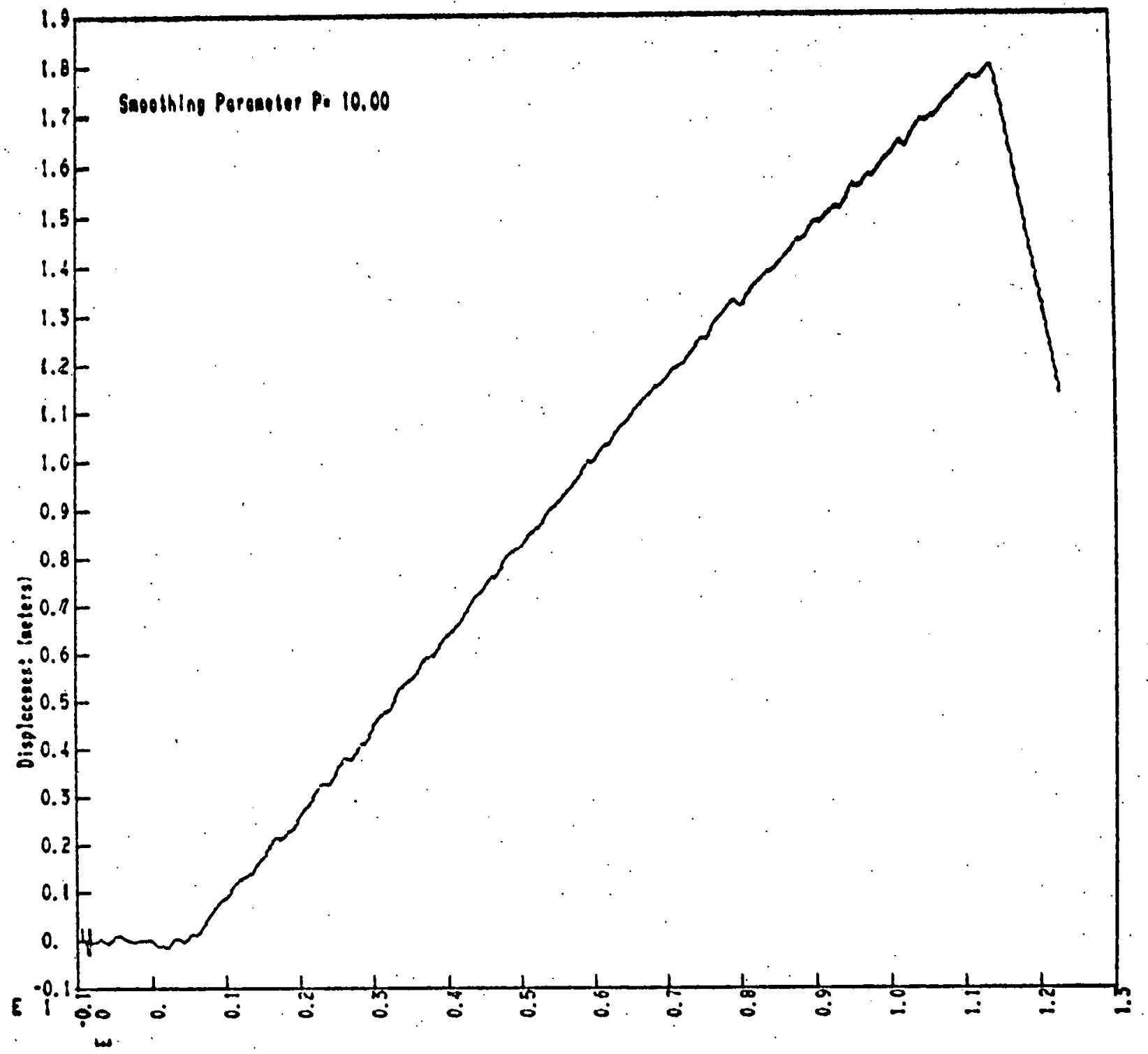

Plat (sec.)

FIGURE "A-31

Vertical Displacement Target 15

$-48-$ 


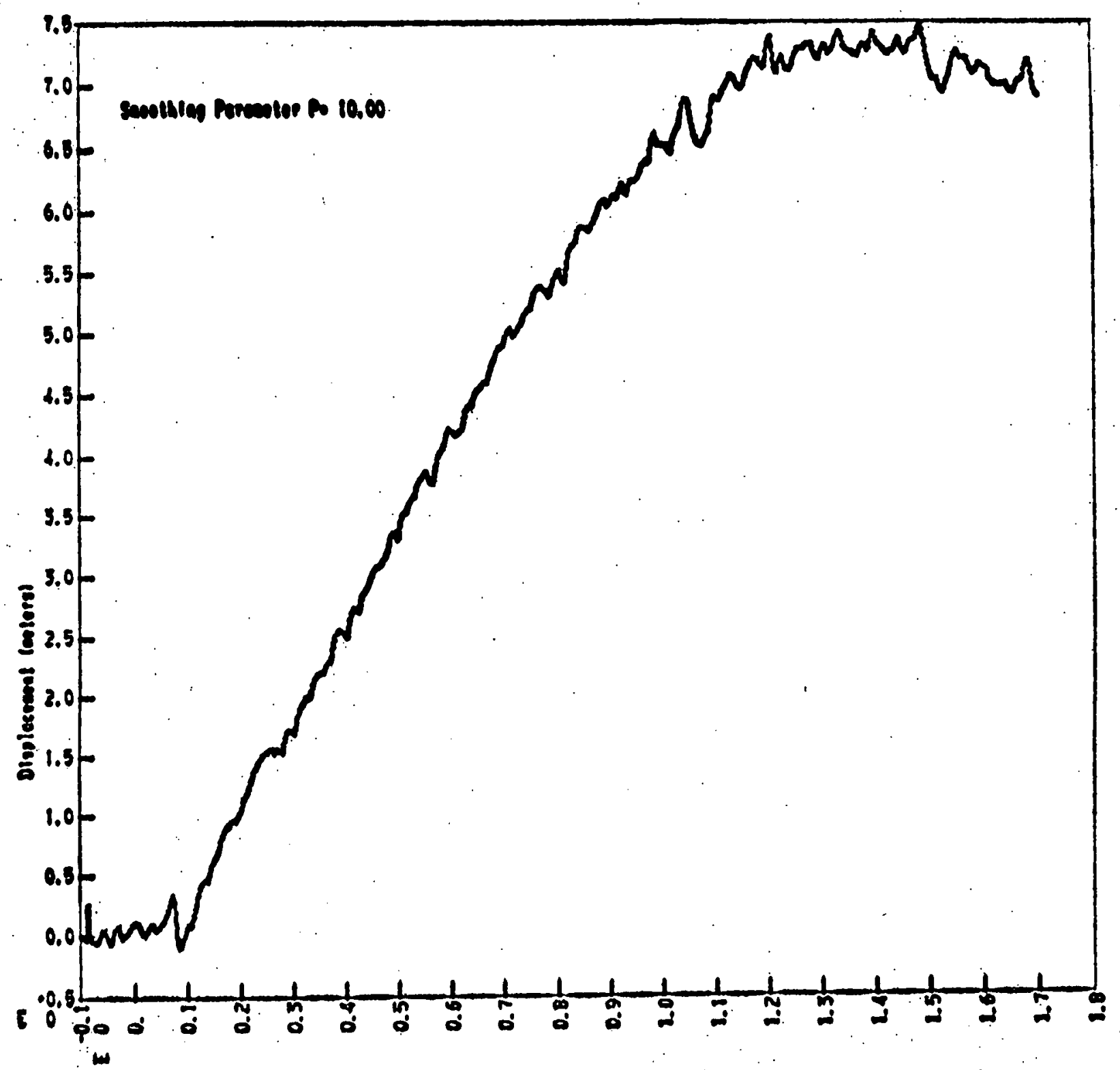

Plee lones

FIGURE A-32

Vertical Displacement Target 16 


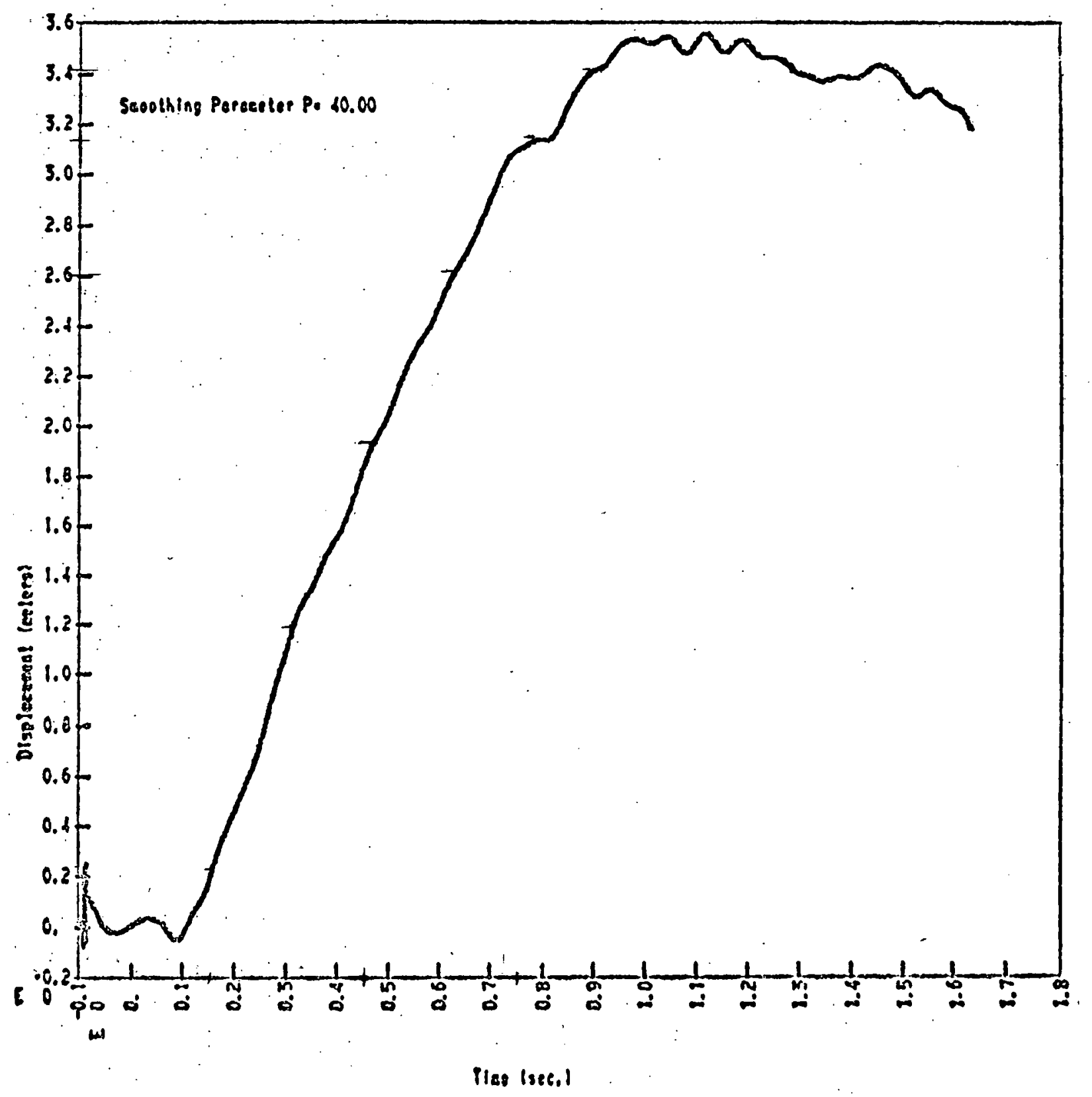

FIGURE A-33

Vertical Displacement Target 1

$-50-$ 


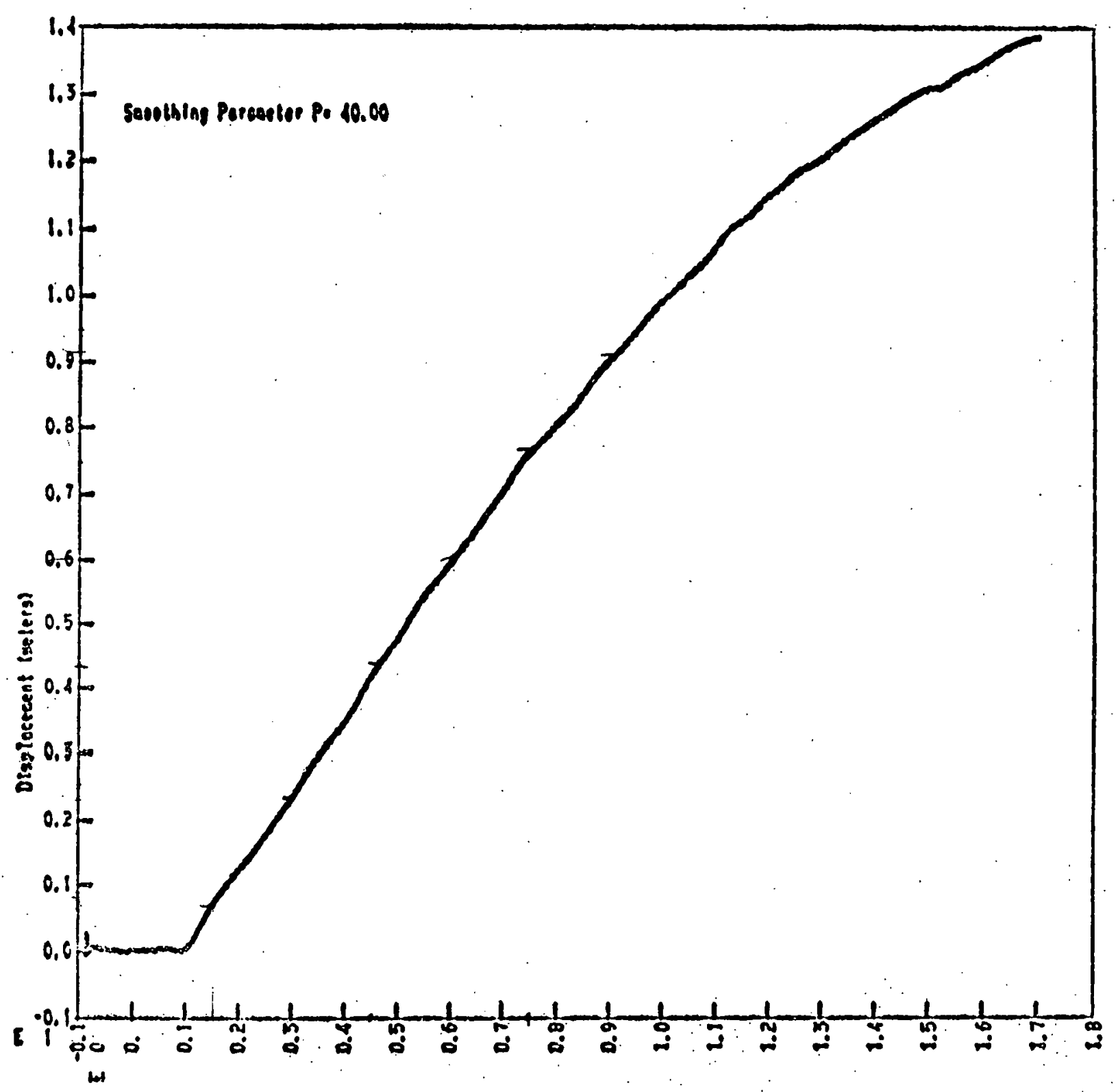

Ilso lo26.1

FIGURE A-34

Vertleal Displacenent Target 2 


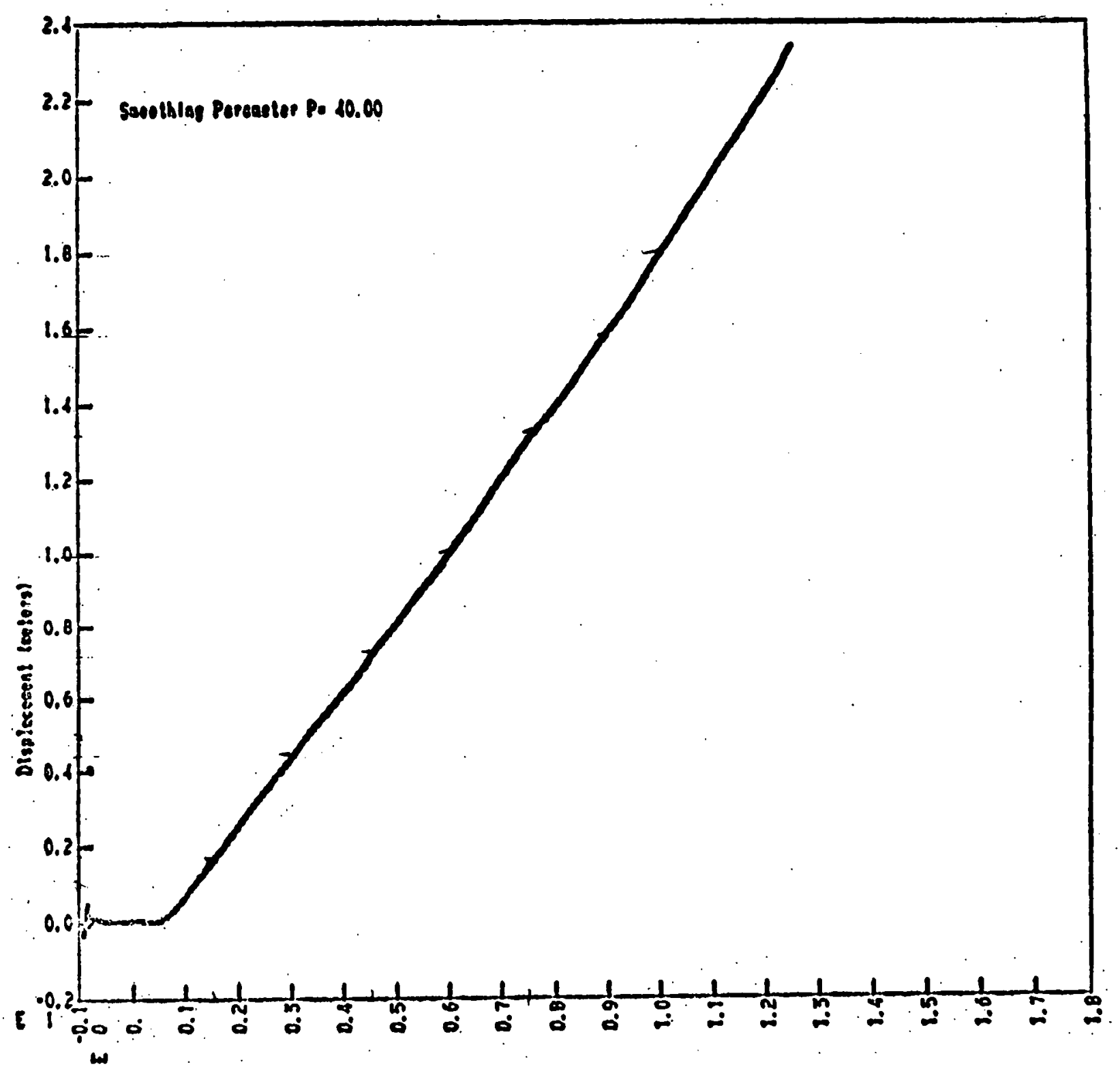

Plep loce.l

FIGURE A-35

Vertlod Displacement Target 5

$-52-$ 


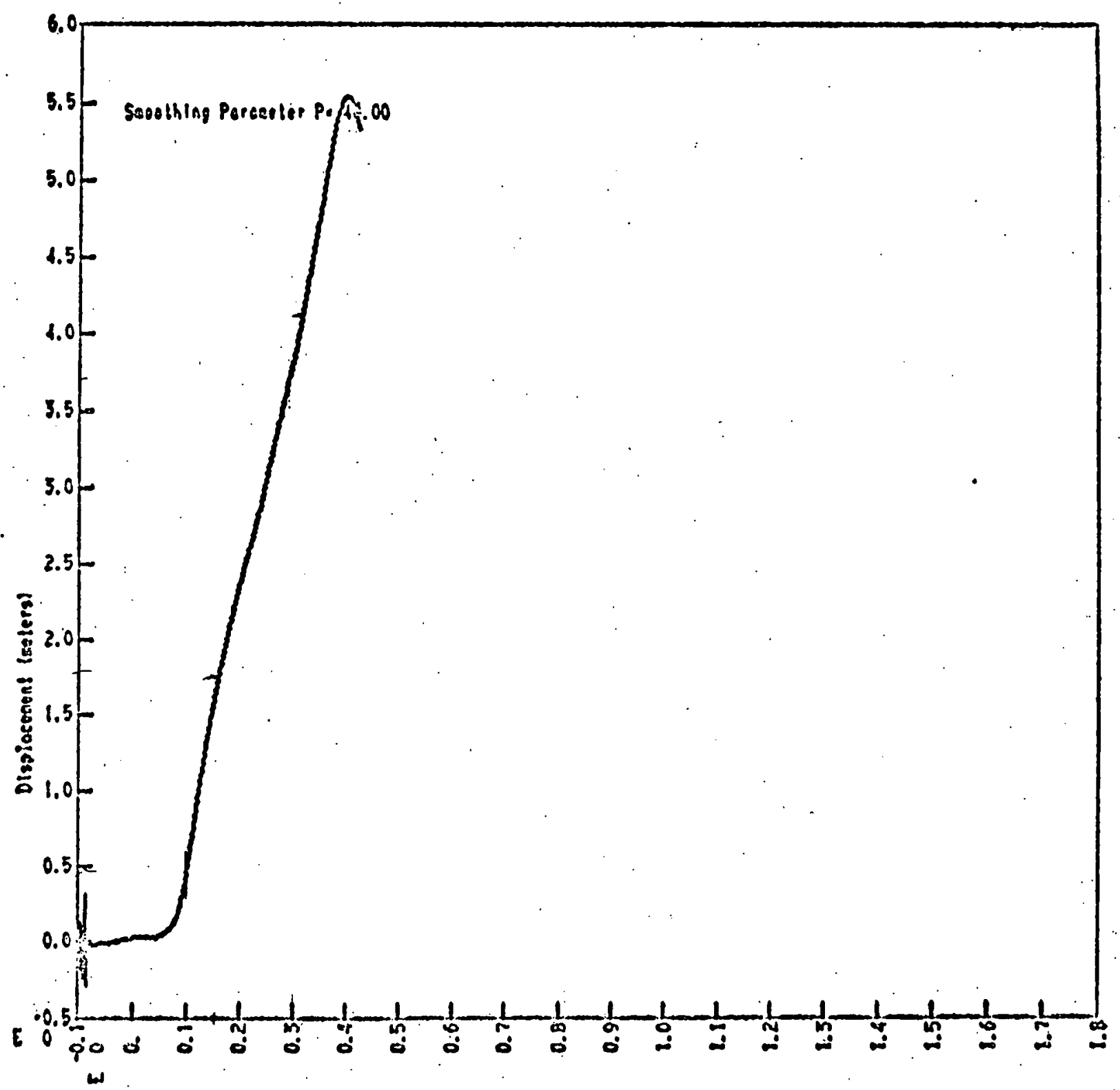

Pleo lses.)

FIGURE A-36

Vertical Displocement Torget a

$-53-$ 


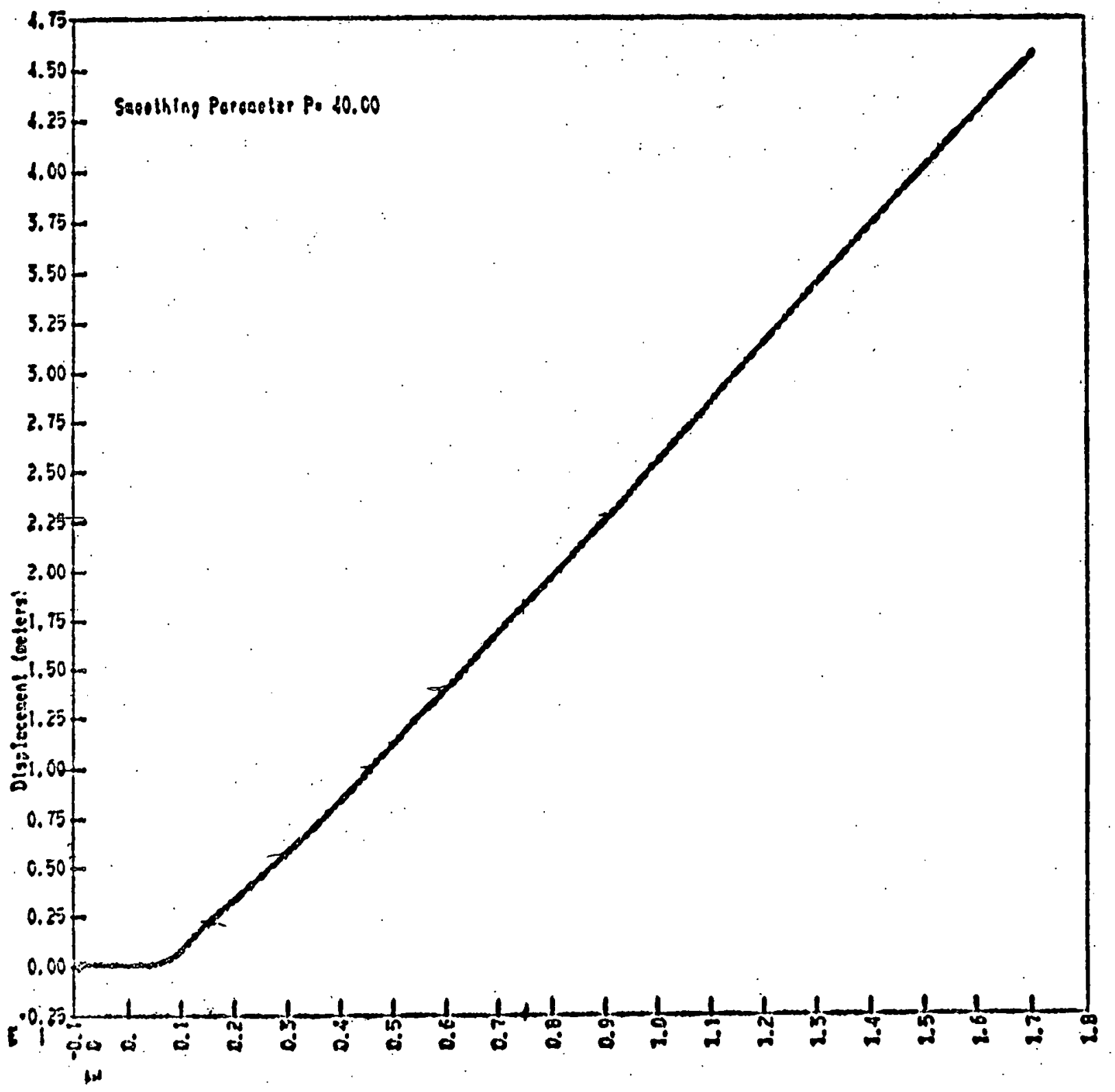

Pize $1886, \mid$

f lovre a-37

Vertleol Displacoment Target 5

-54- 


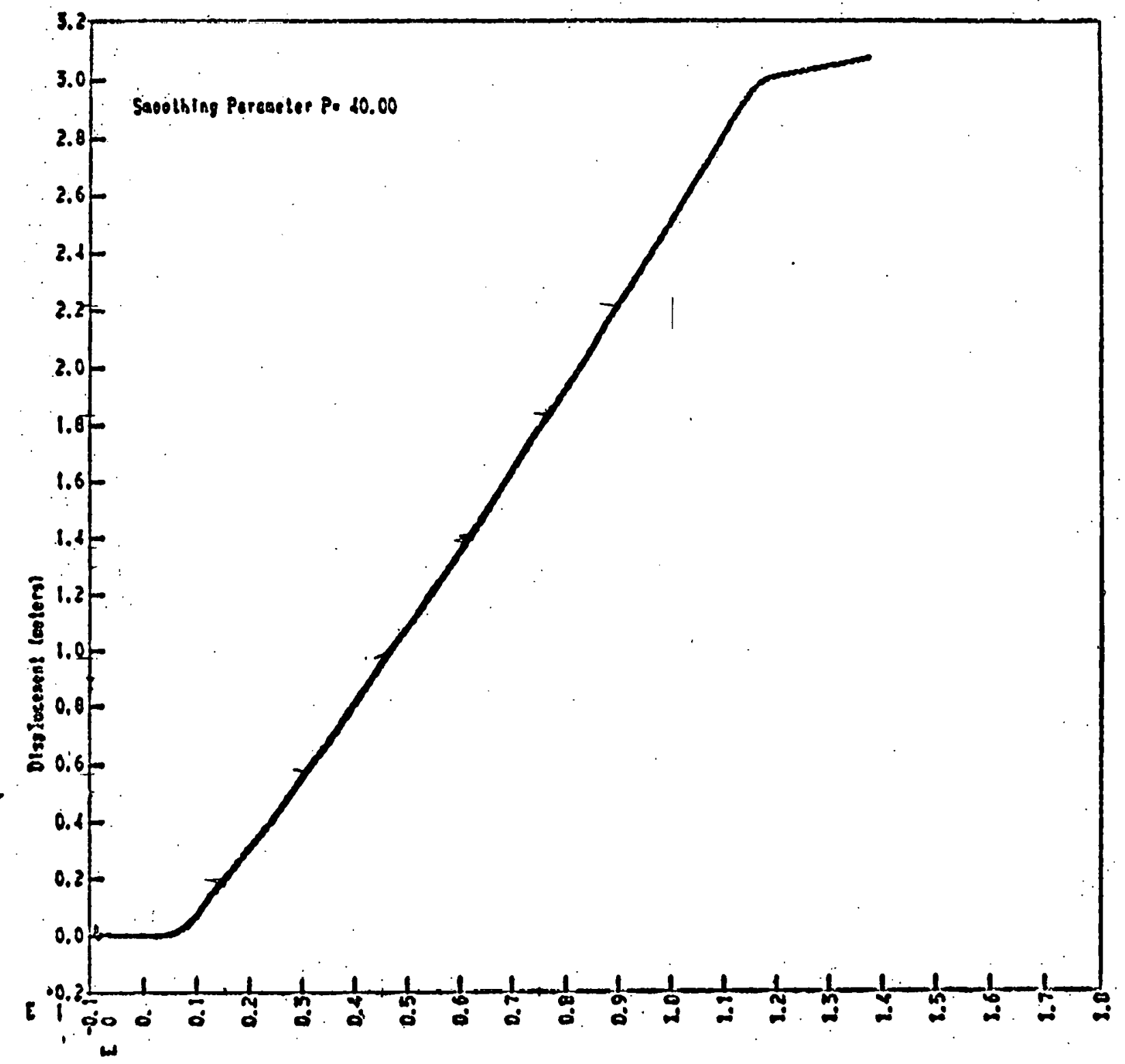

Ples loes,

FIGURE A-38

Yertical Displacerent Target 6

$-55-$ 


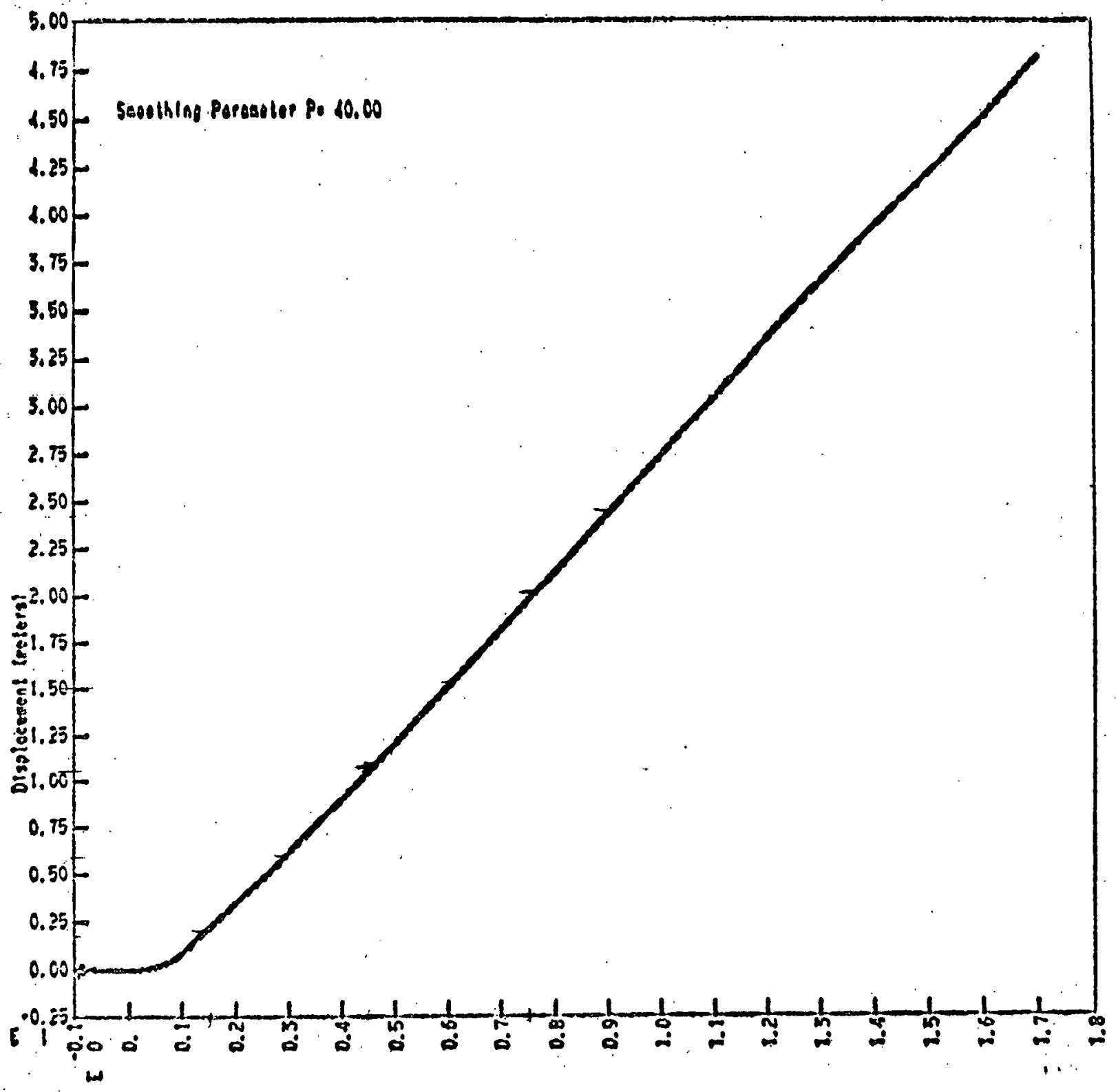

Plae lose.)

F IGURE A-39

Yertical Displacerient Tapget 7

$-56-$ 


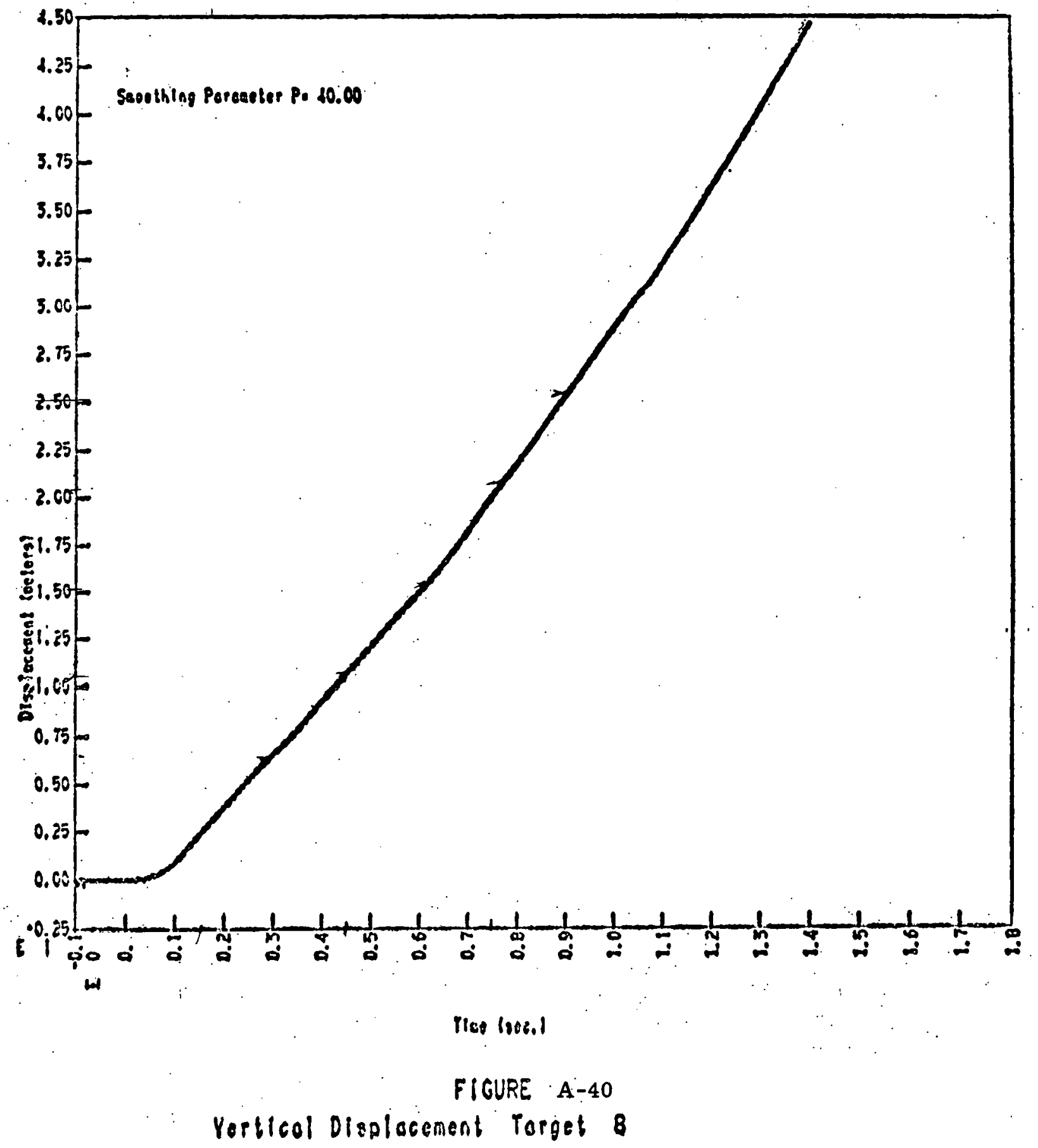

$-57-$ 


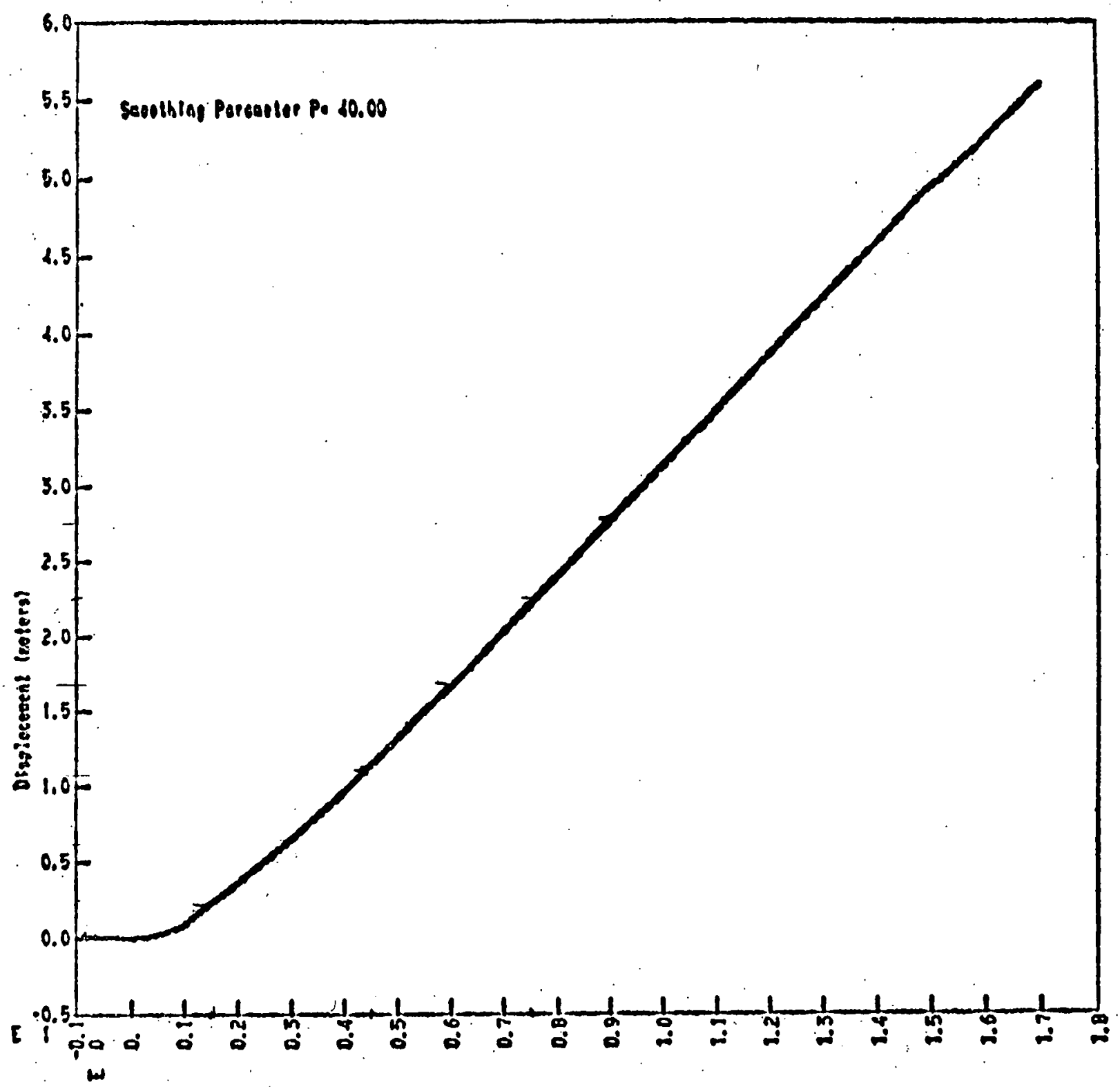

llee (19es)

FIGURE $A=41$

Veptleal Displacement Torget 9

$-58-$ 


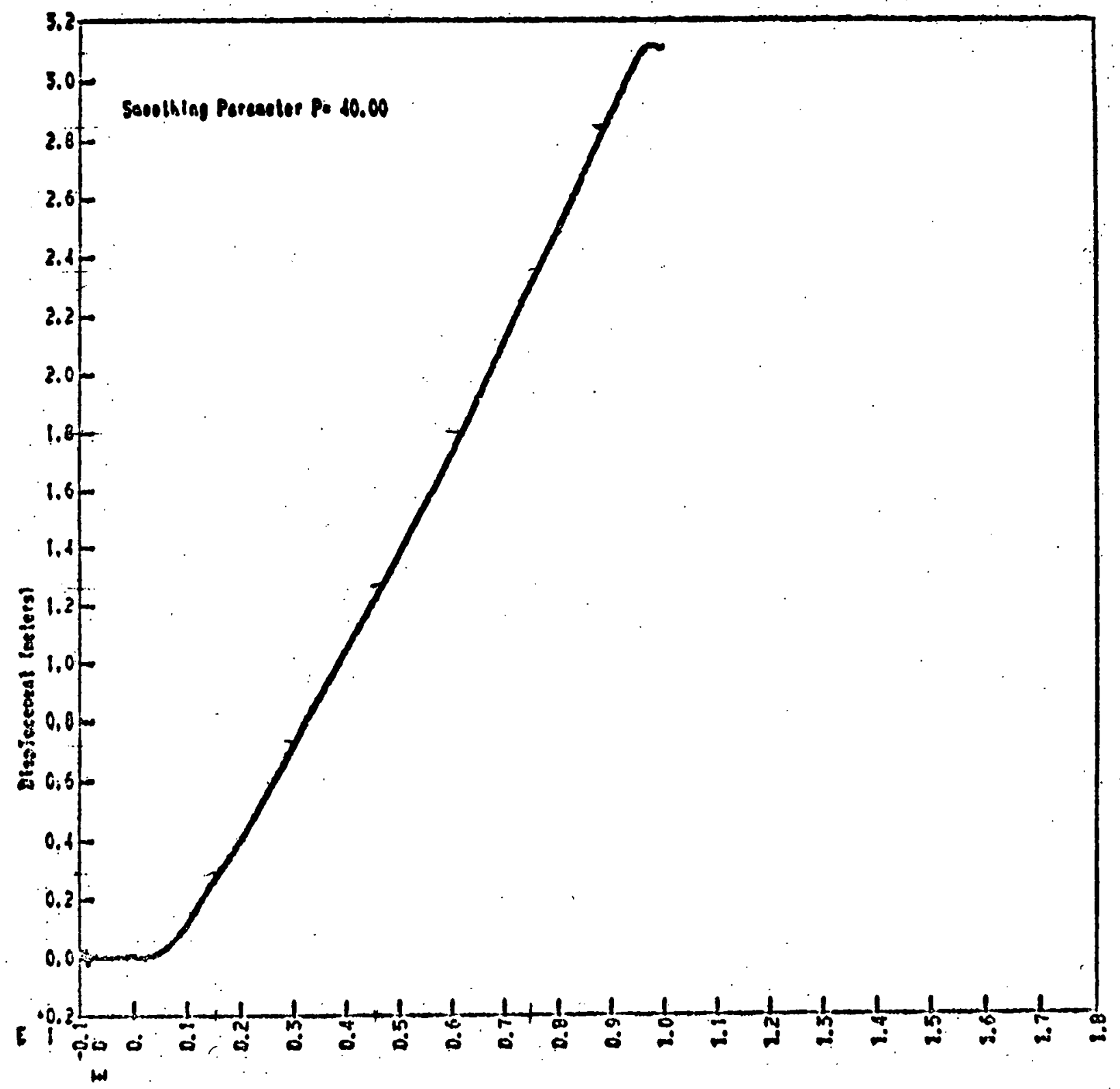

liee (18be)

FÍGURe A-42

Yertlcal Displacement Tapget 10

-59- 


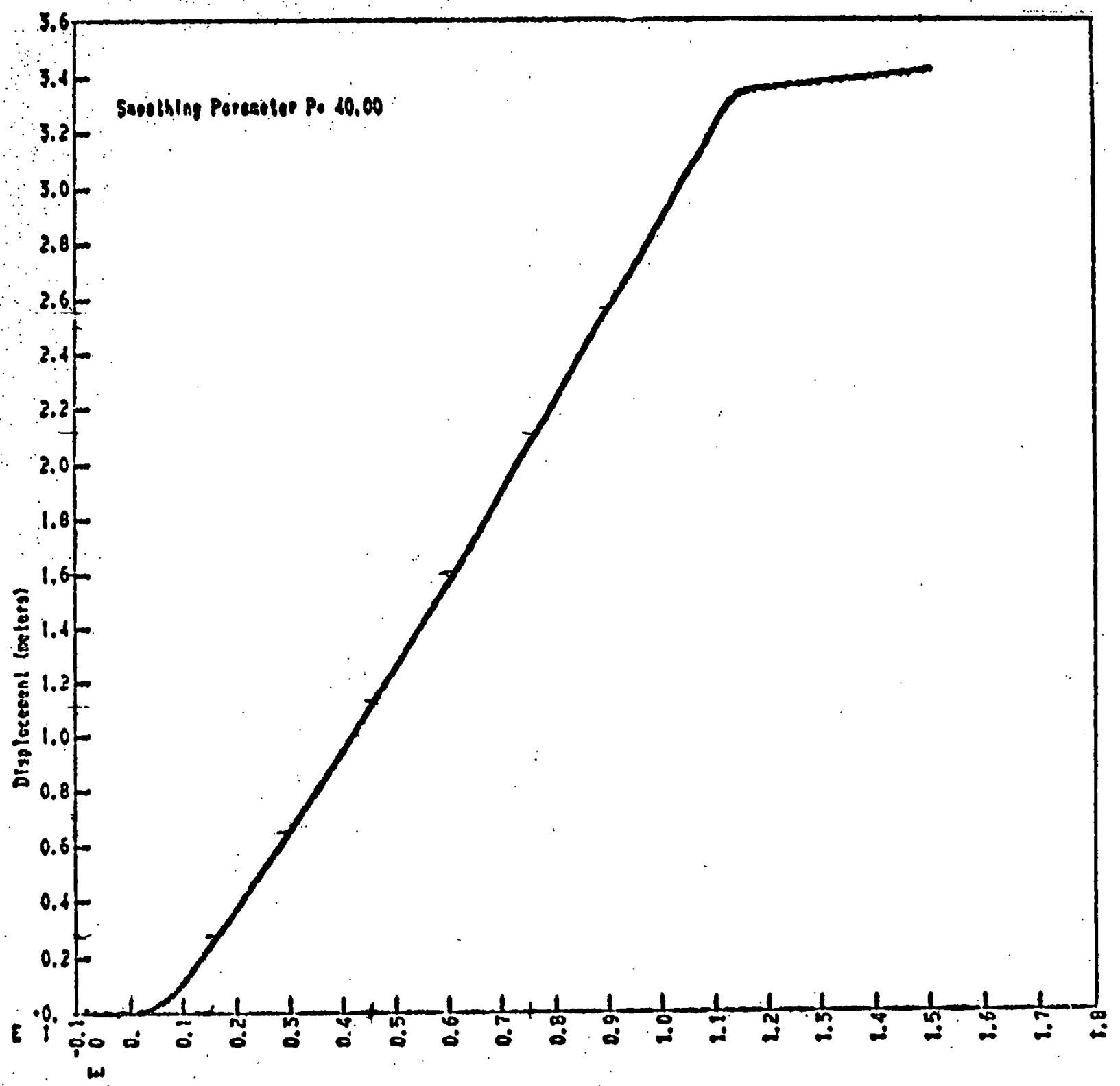

Ties looc.)

FIGURE A-43

Yertical Displocenent Target 11

$-60-$ 


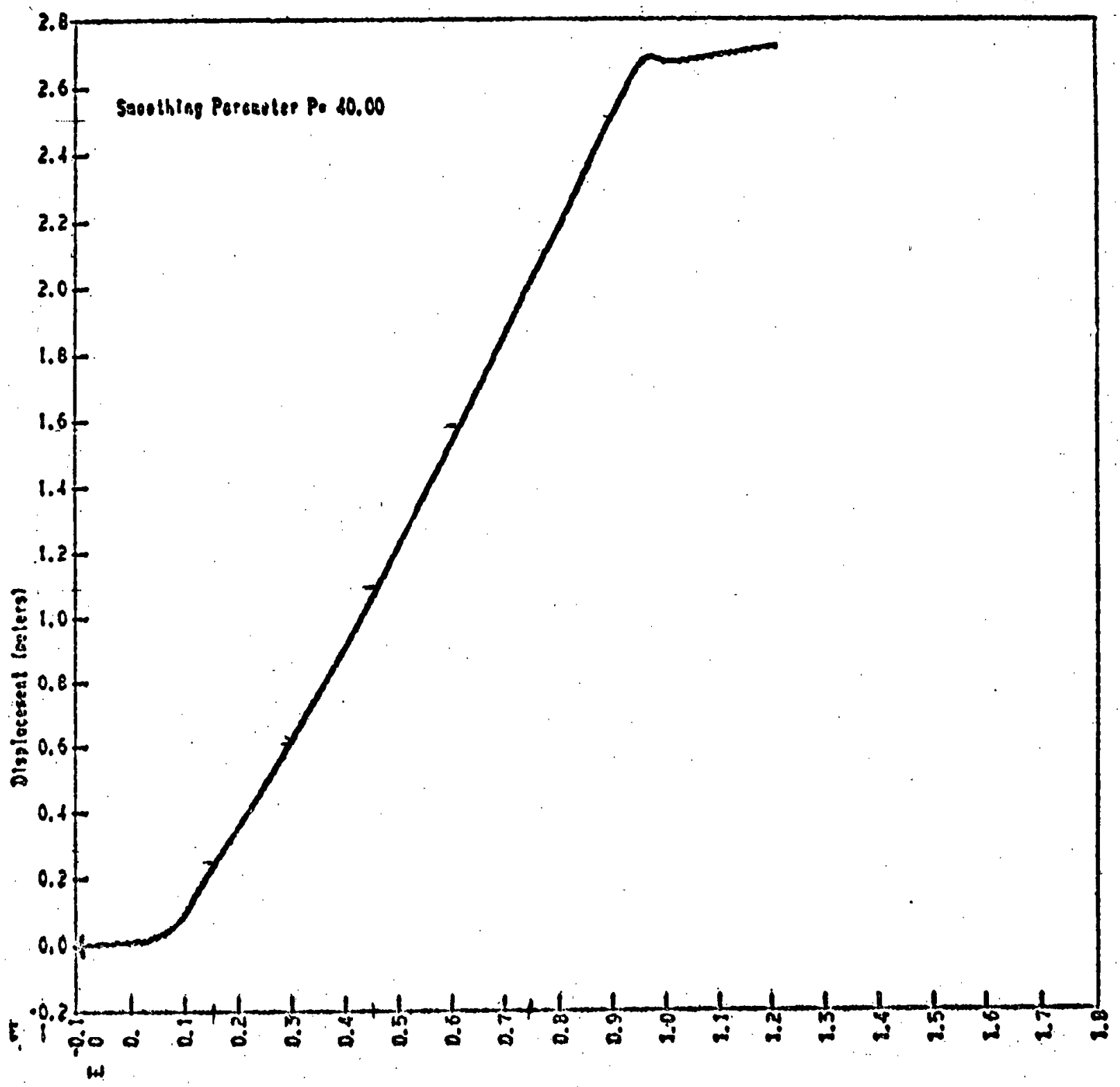

Tias (806.)

FIGURE A-44

Yertlcal Dlsplacement Target 12 


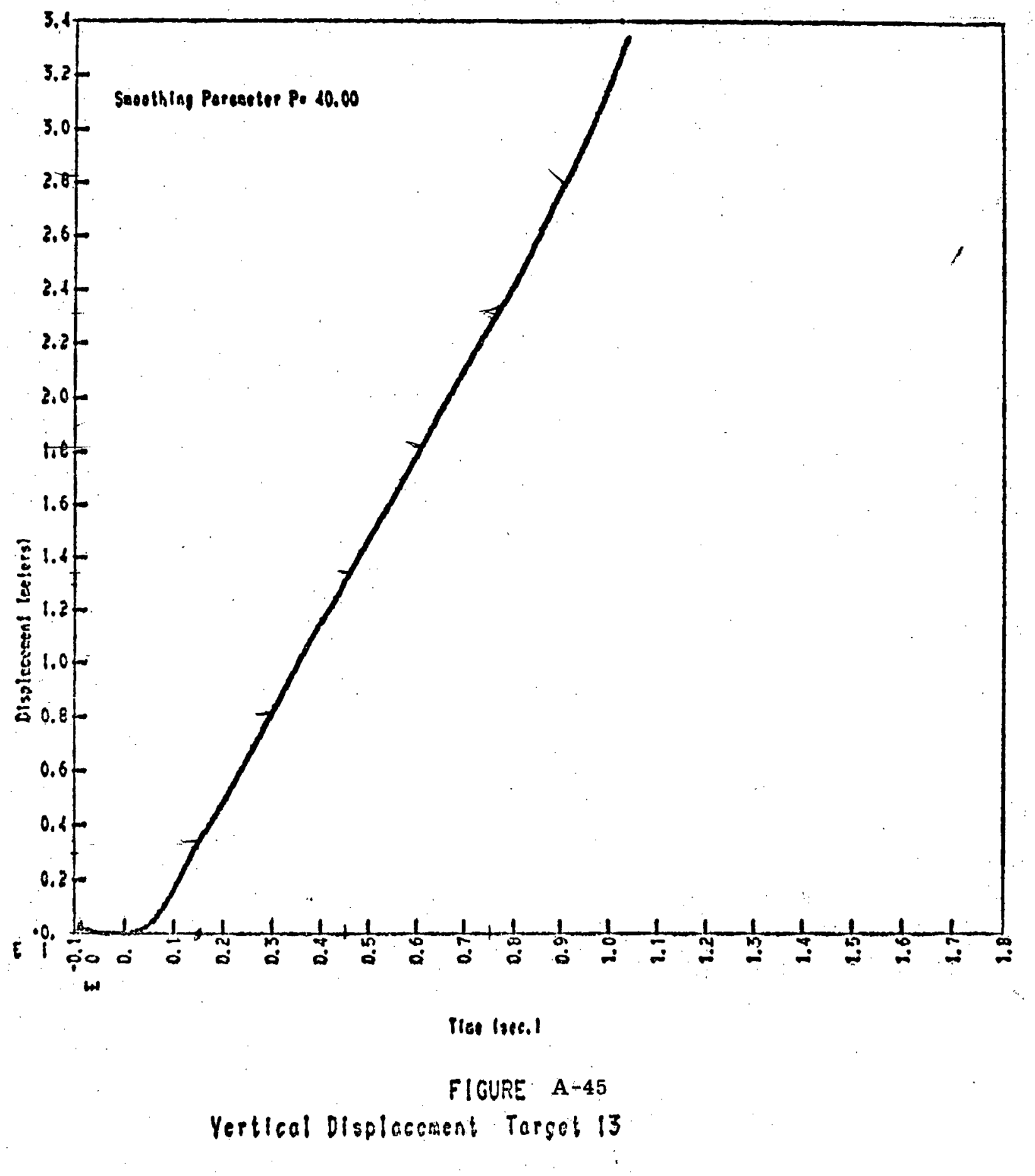

$-62-$ 


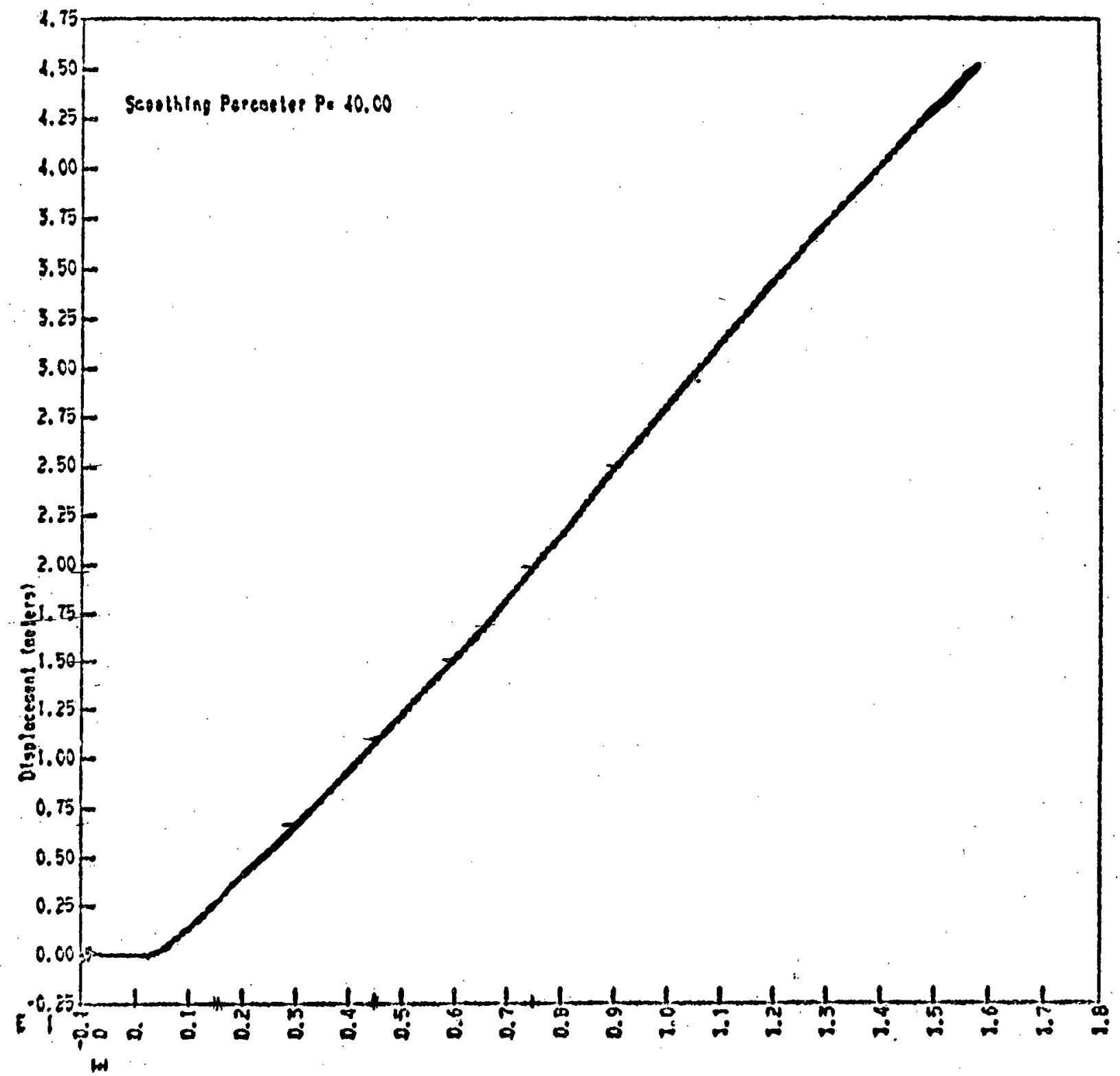

Plea loobl

FIGURE A-46

Vertlcal Displocement Torget it

$-63-$ 


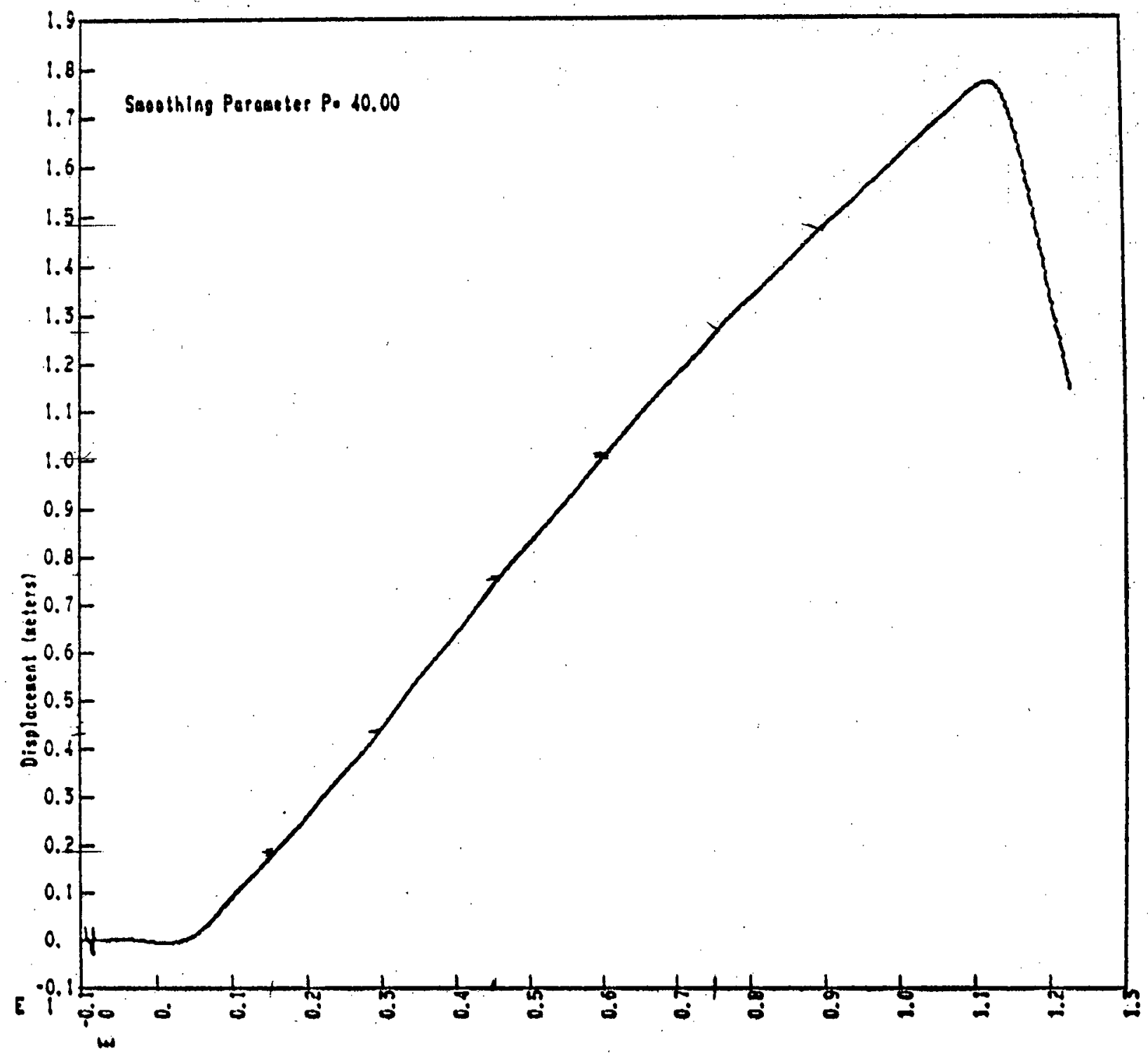

Tian lsee.)

FIGURE A-47

Yertlcal Displacement Target 1 h

$-64-$ 


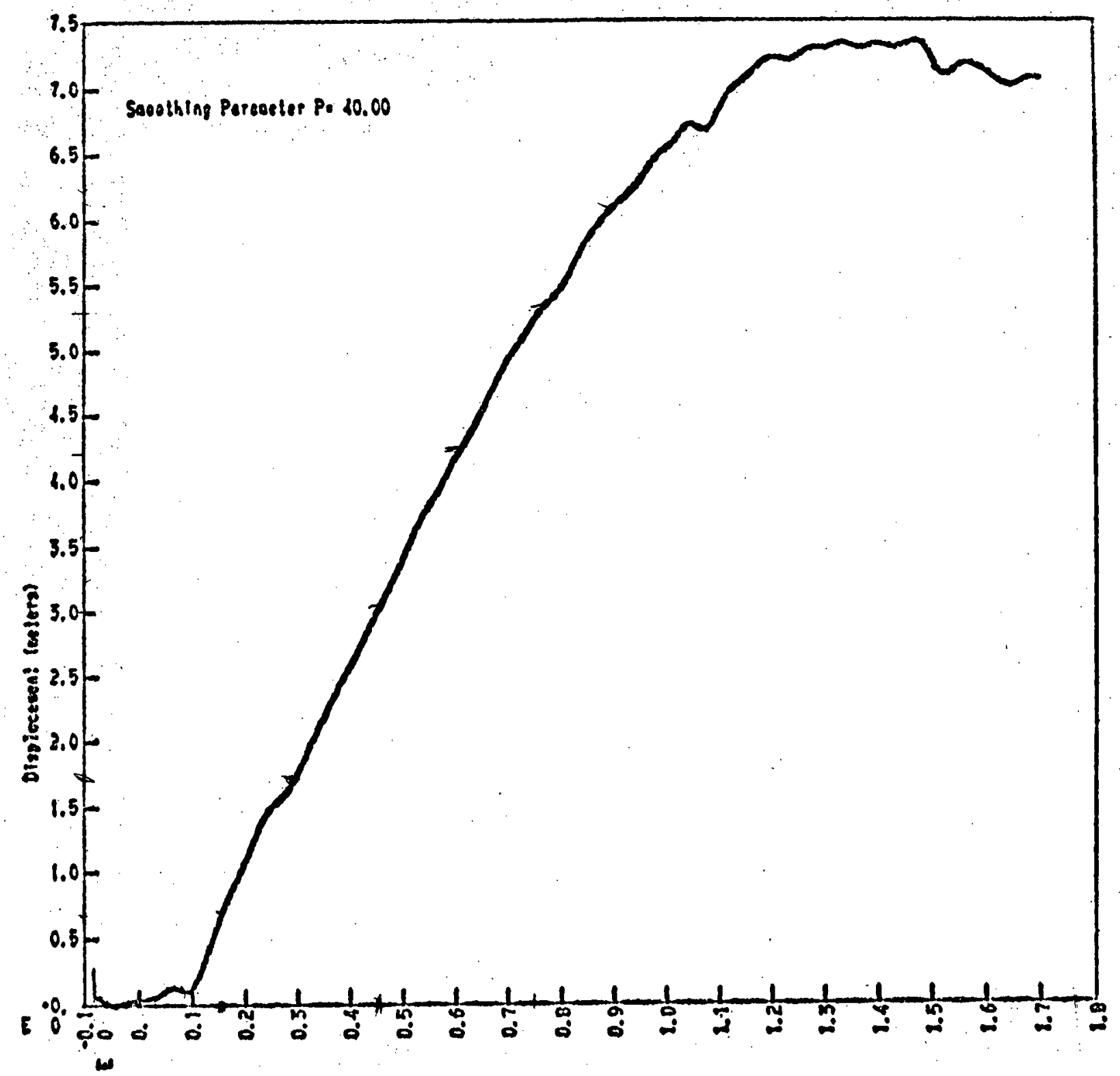

Plase lses.)

FIGURE A-AB

Yeptlcal Dlsplocement Torget 16

$-65-$ 


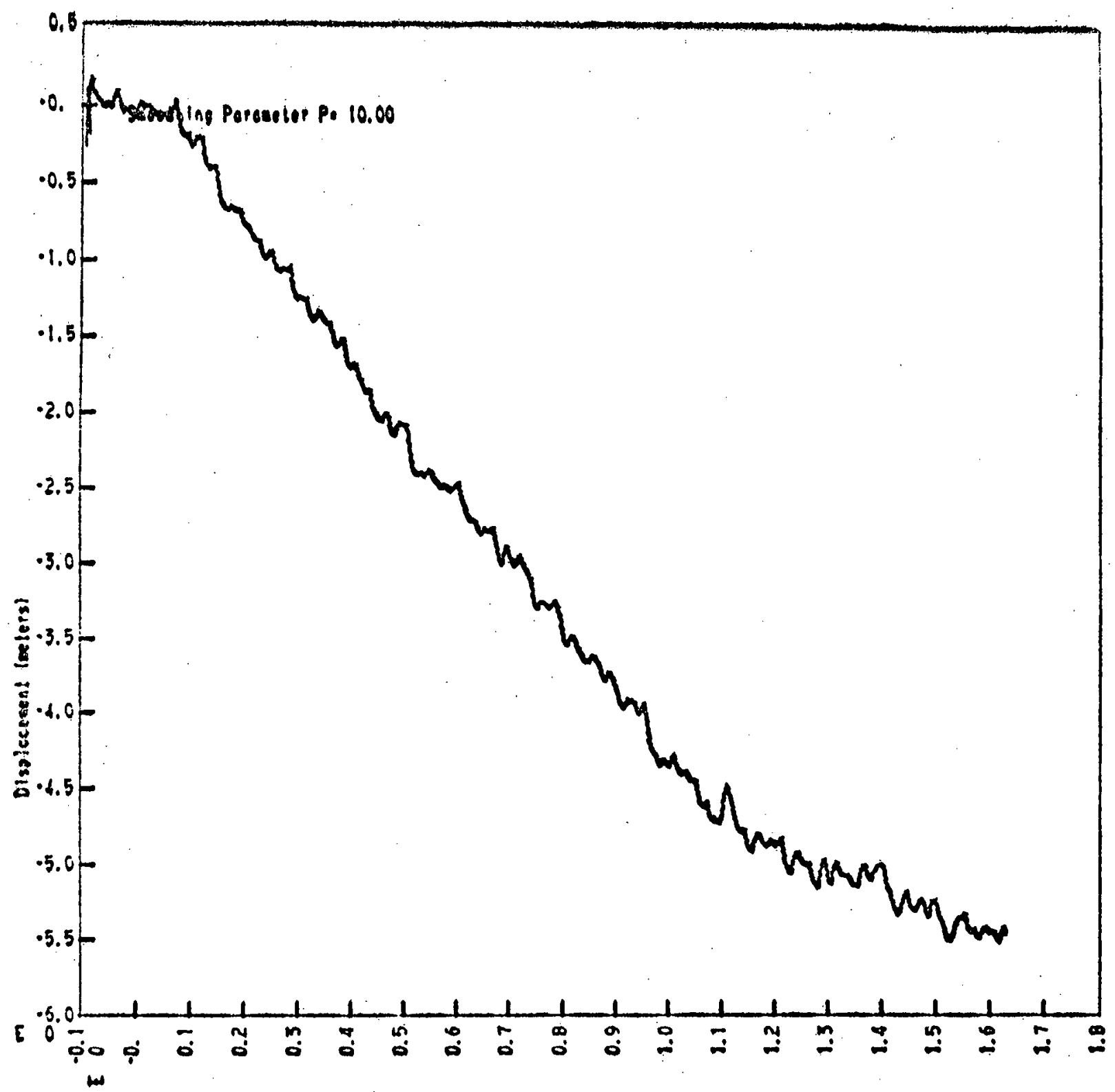

Pies loce.)

FlCURE A-49
Horlzontal Displocement Tapget 1

$-66-$ 


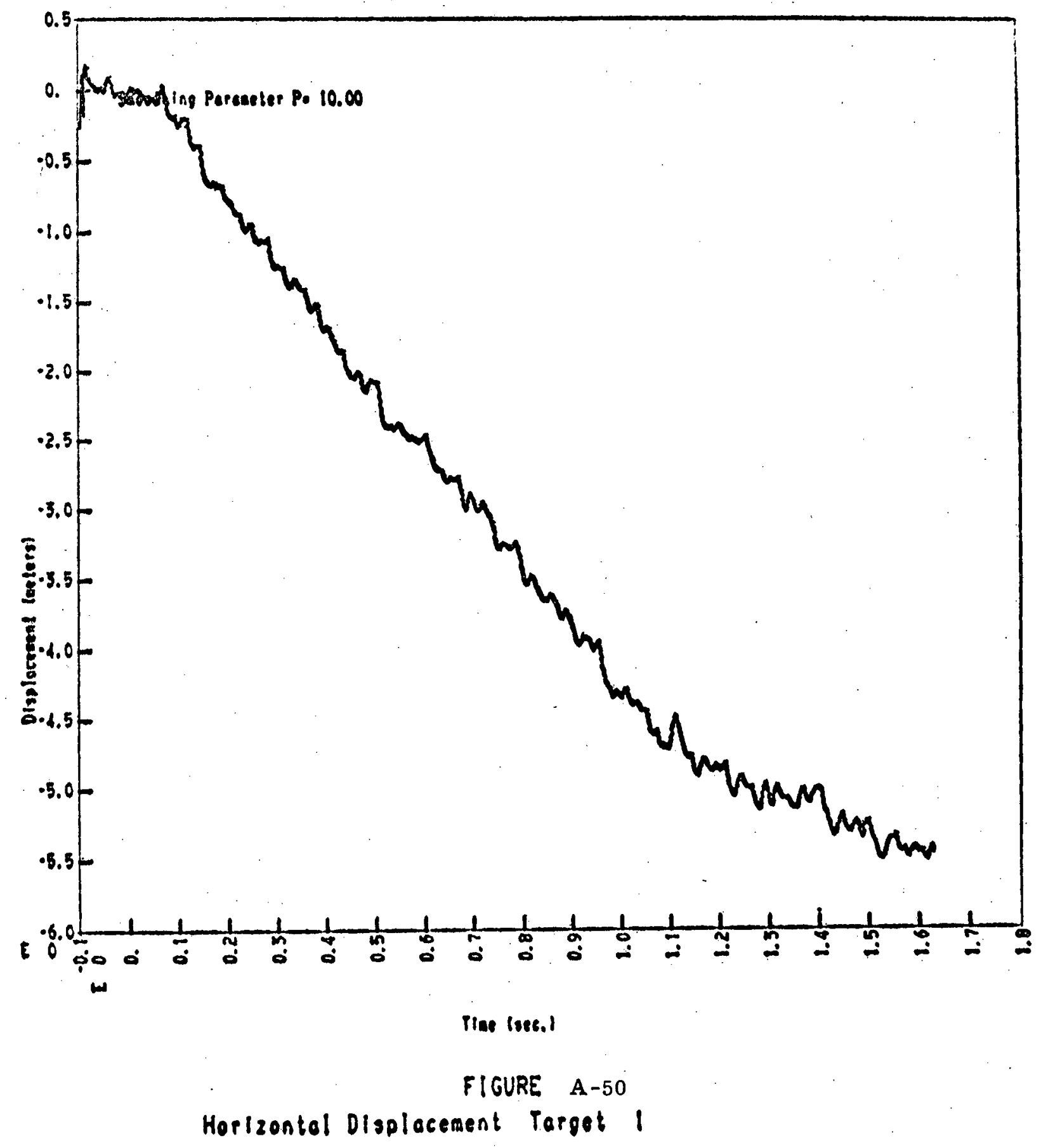

$-67-$ 


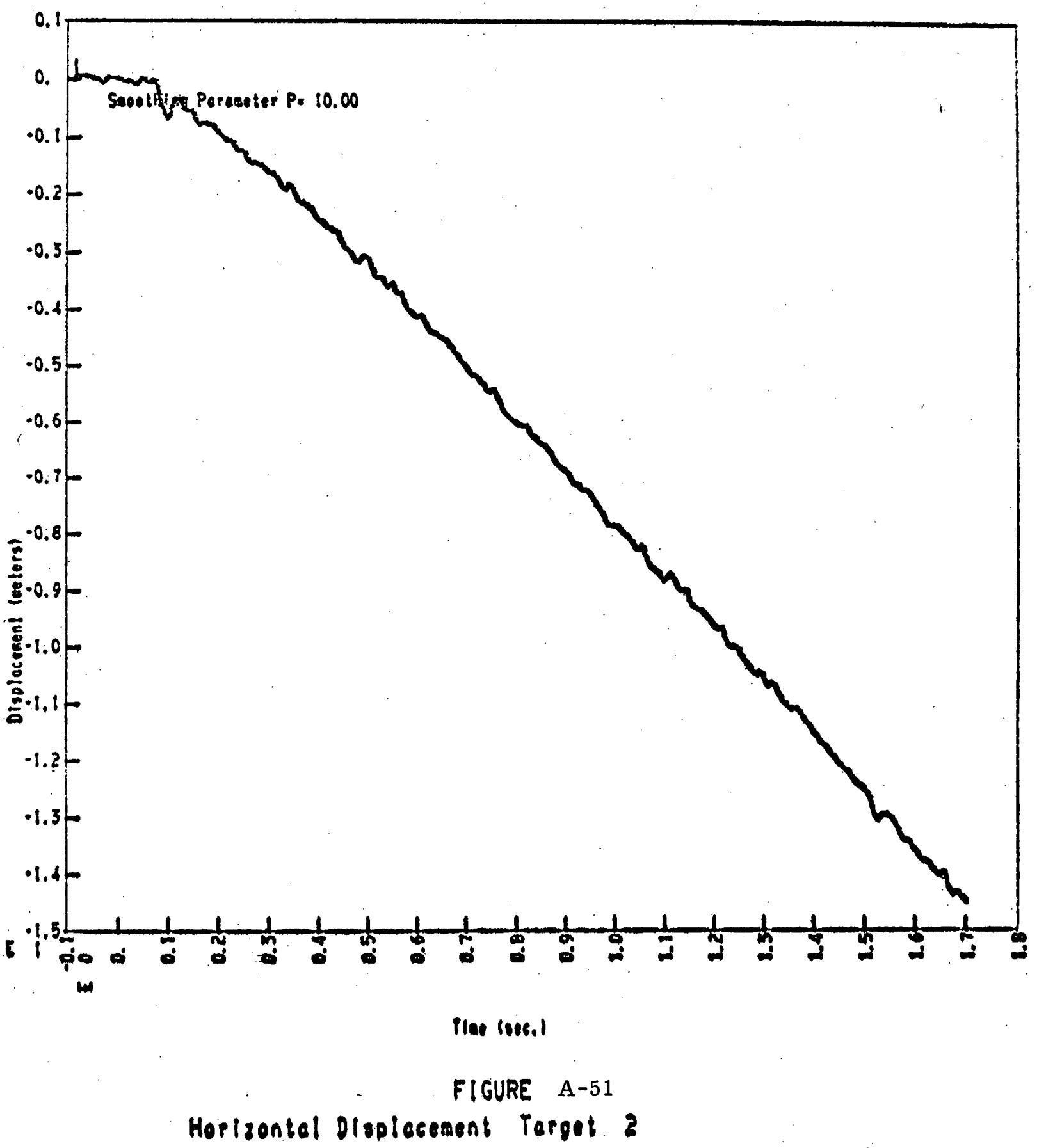

$-68-$ 


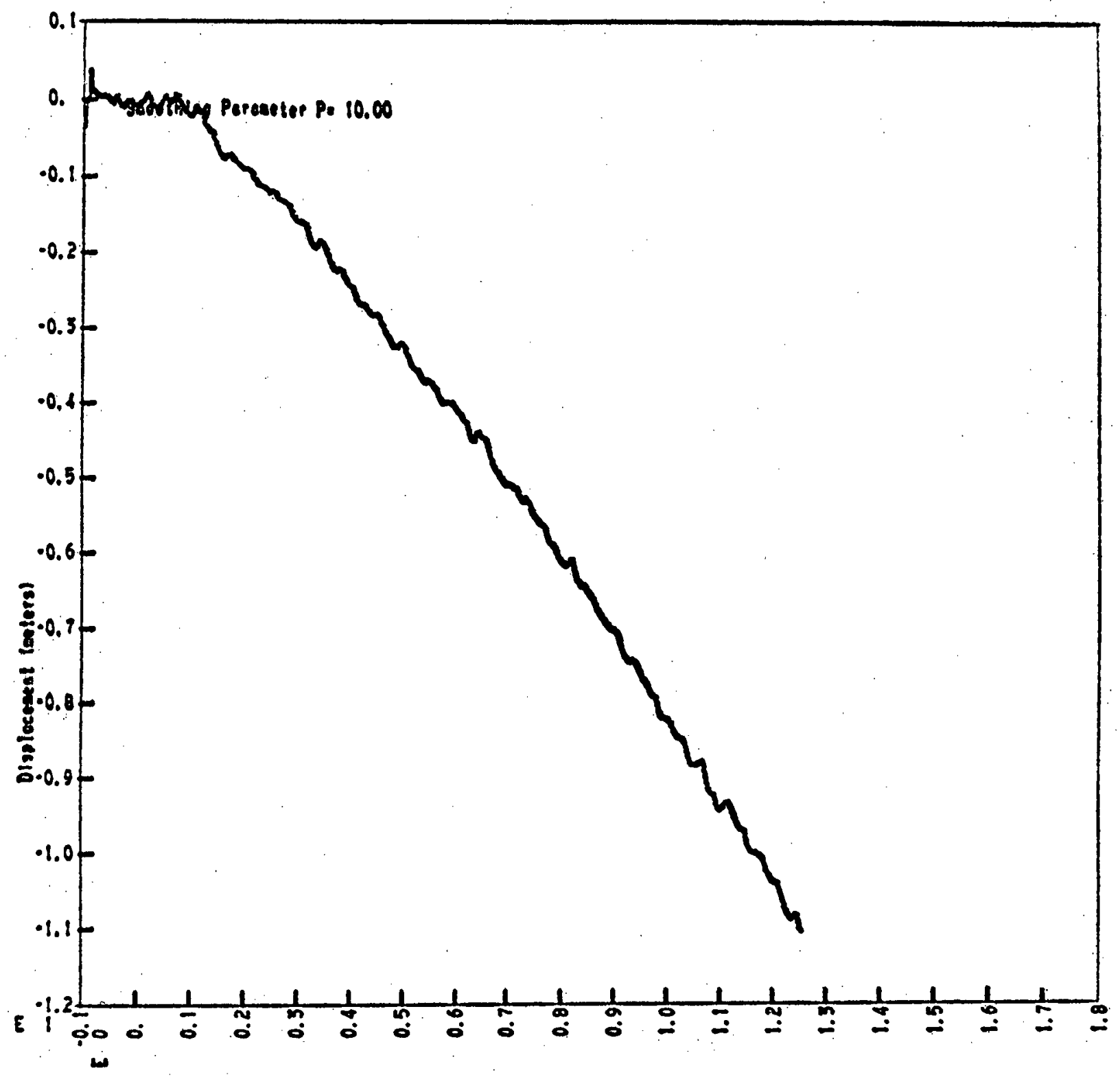

Ties (sec.)

FIGURE A-52

Horizontal Displacement Target 3

$-69-$ 


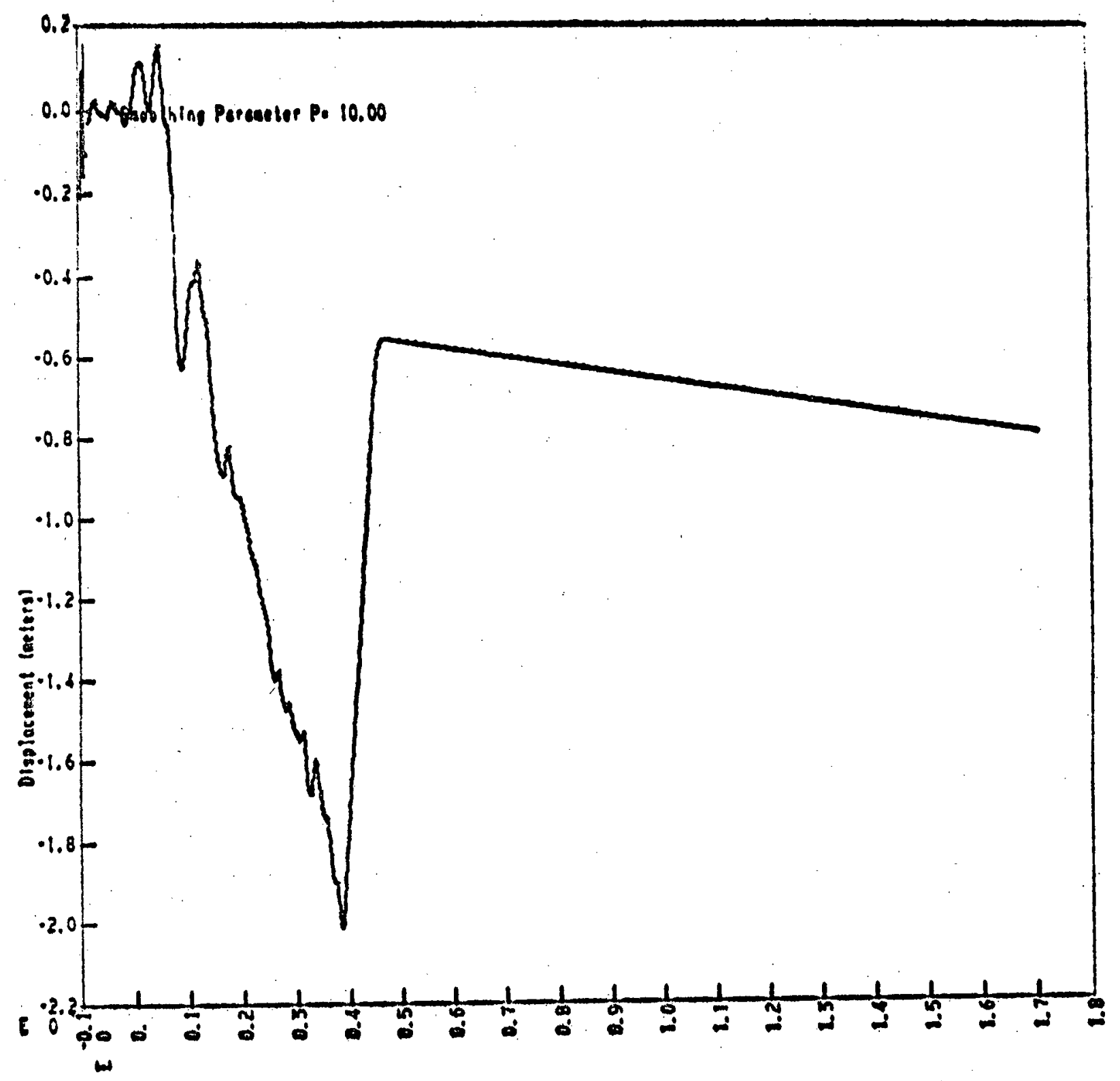

Fiee loesi)

FIGURE A-53

Horlzontal Displocement Target 4

$-70-$ 


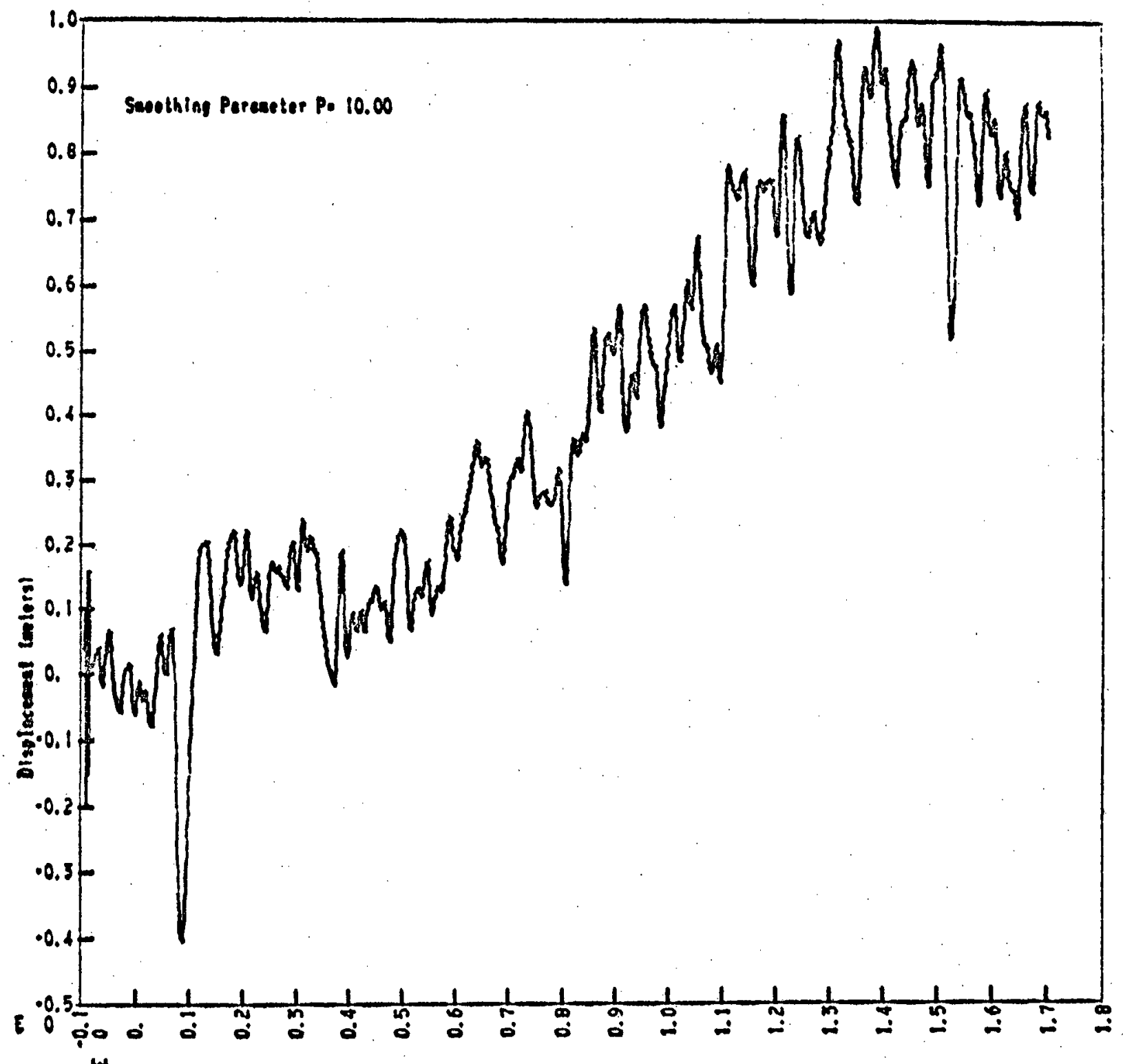

Pien lsece)

FIOURE A-54

Horlzontal Displacement Target 5

$-71-$ 


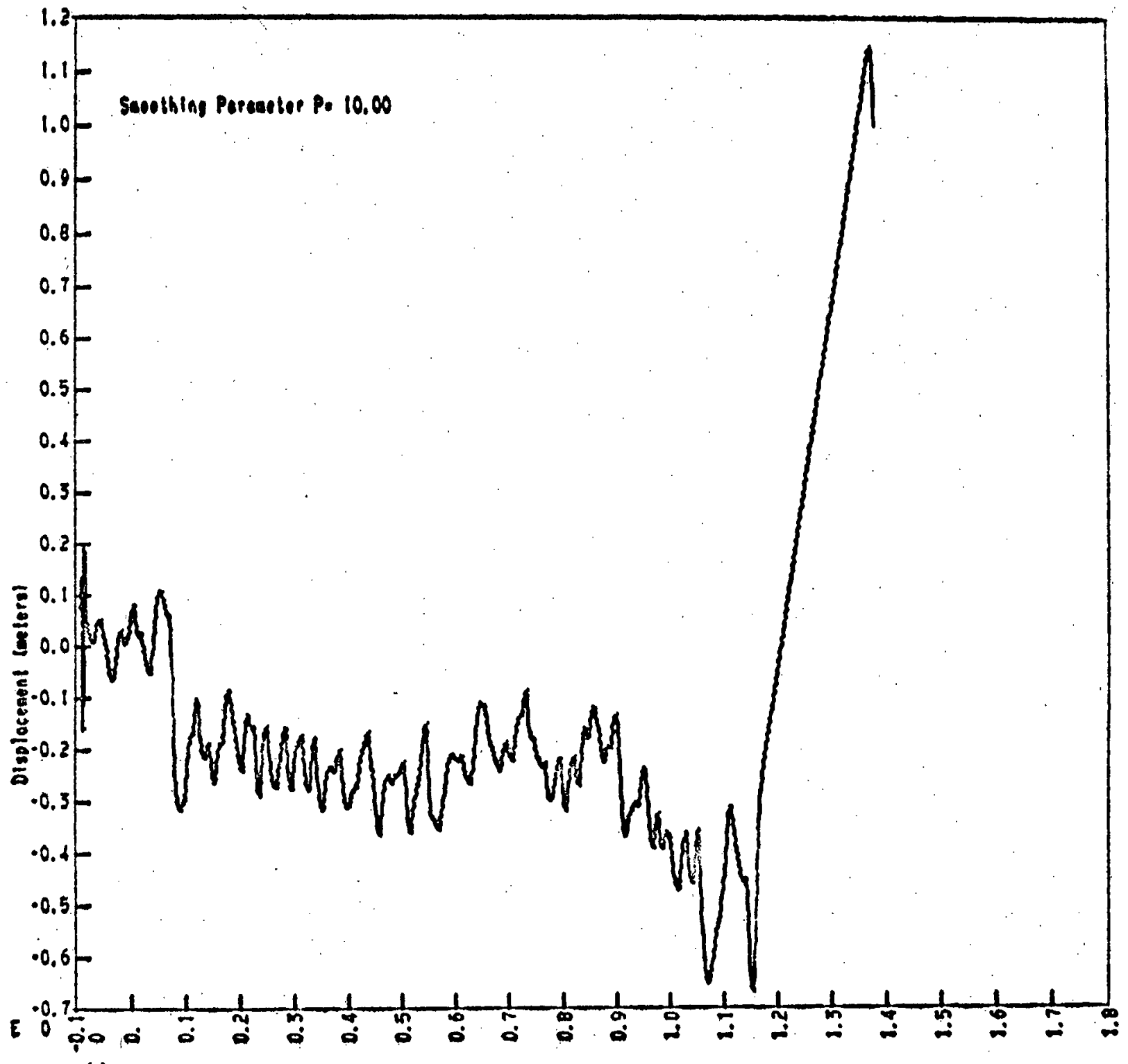

Plac (Bes.)

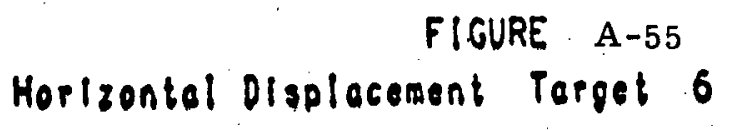

$-72-$ 


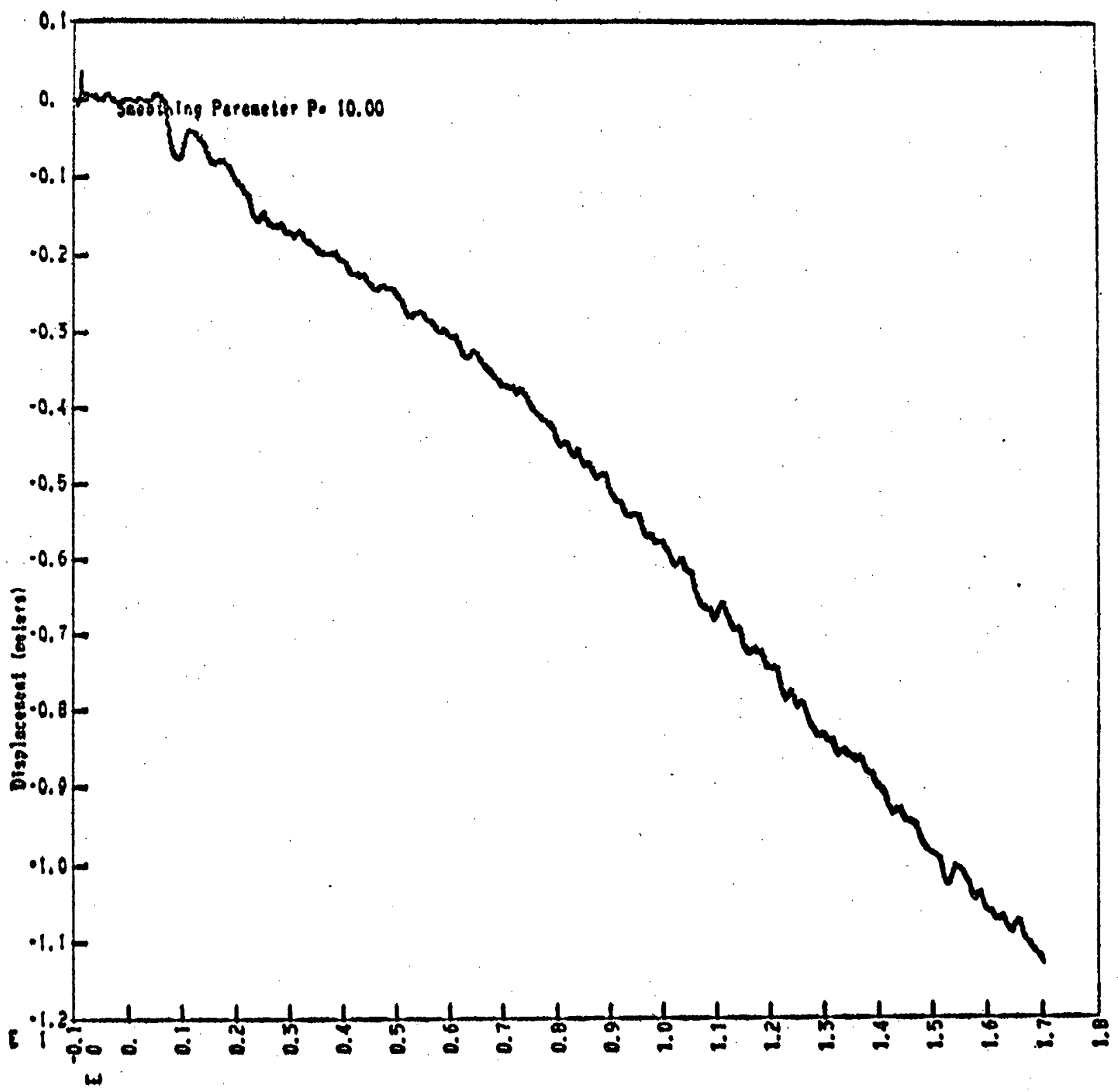

Itee lous.)

FIGURE $A \div 56$

Horizontal Displacement Torget?

$-73-$ 


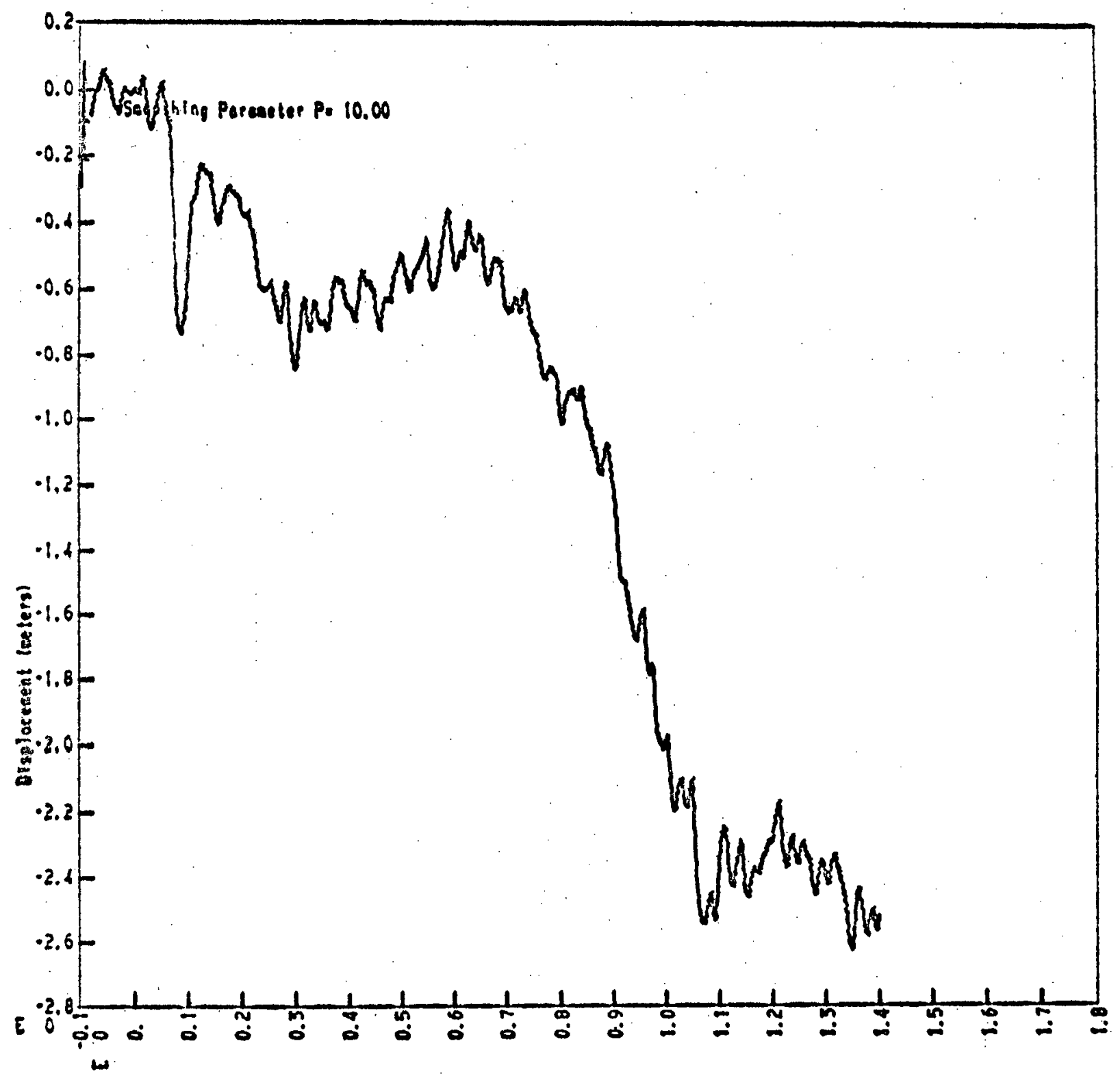

Tien lope.)

FIGURE A-57

Horlzontal Displocement Torget 8

$-74-$ 


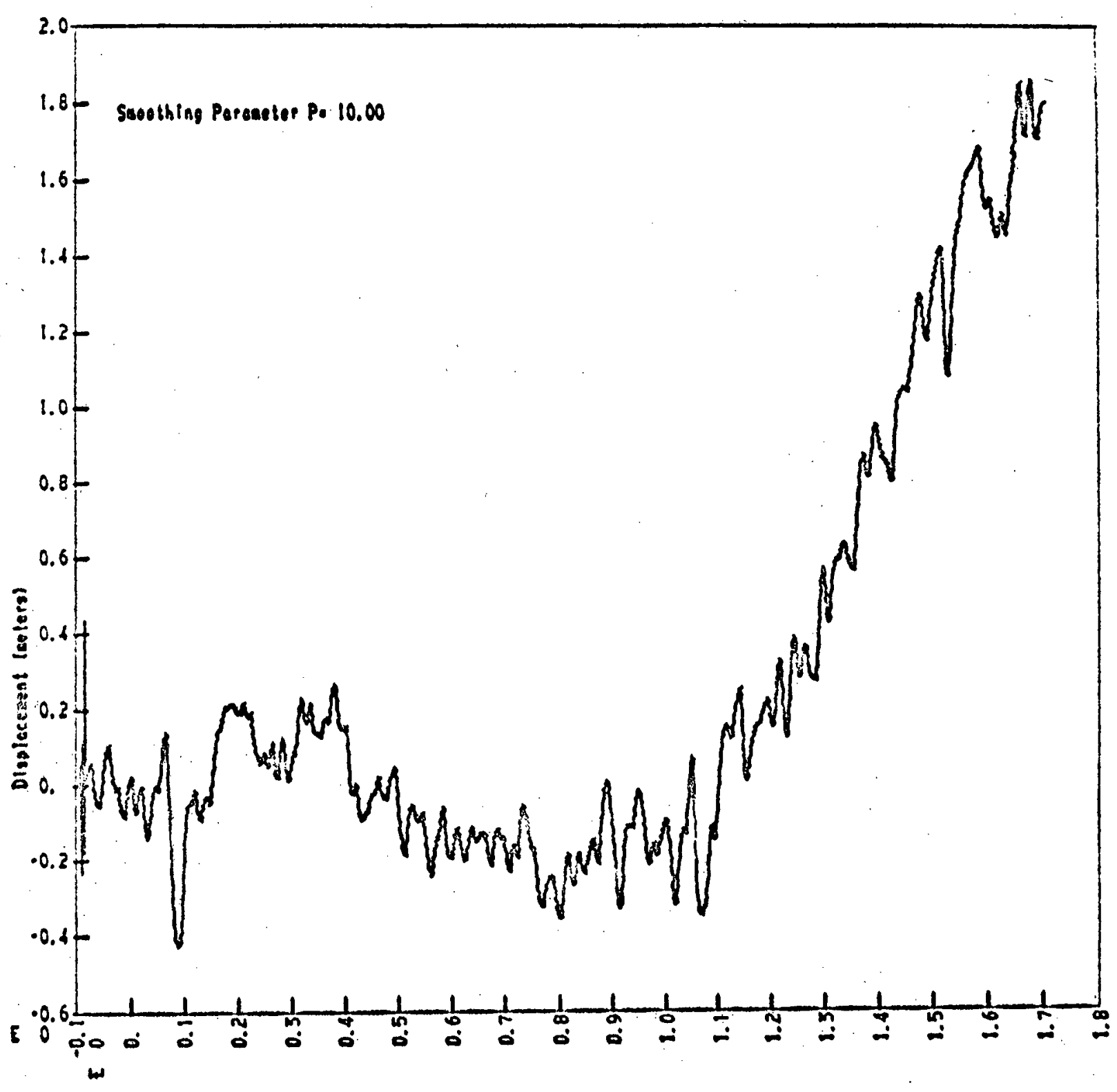

Plas lso6.)

FIGURE A-58

Horizontal Displacement Target 9 


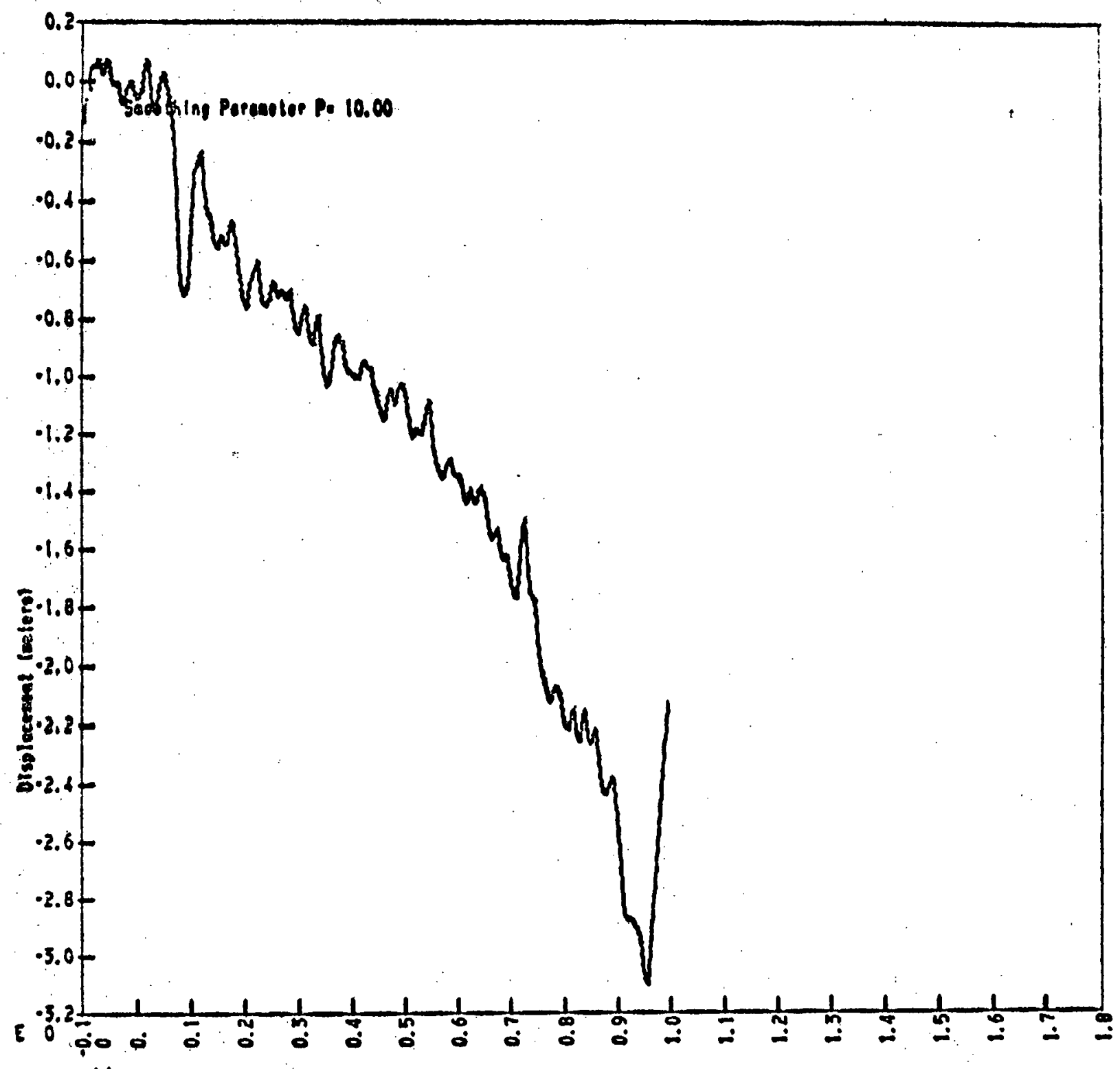

Ties lace.)

FIGURE A-59

Horizontal Displacement Target 10

$-76-$ 


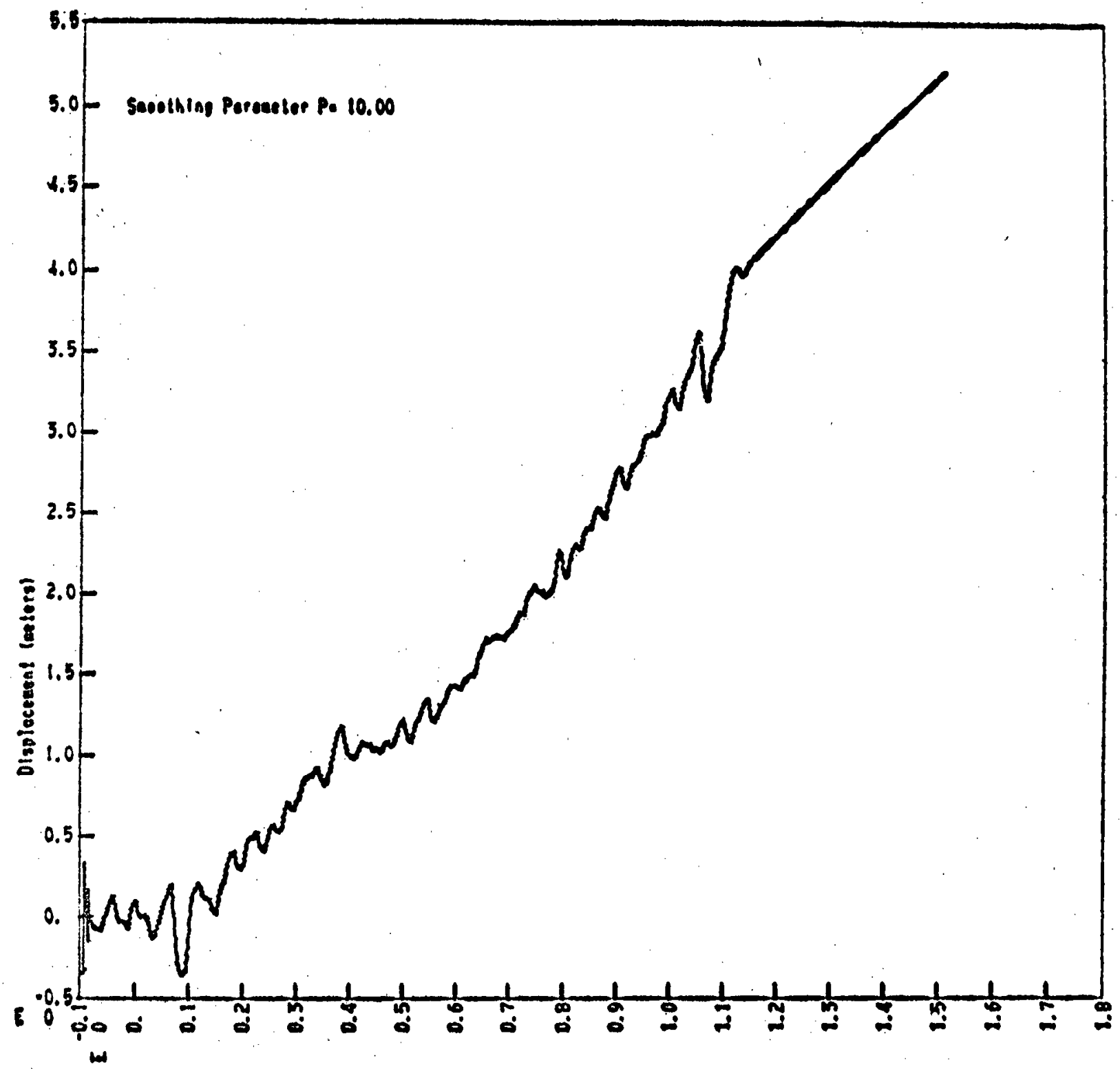

Tlee (soe.)

FIGURE A-60

Horizontal Disolacement Target II

$-77-$ 


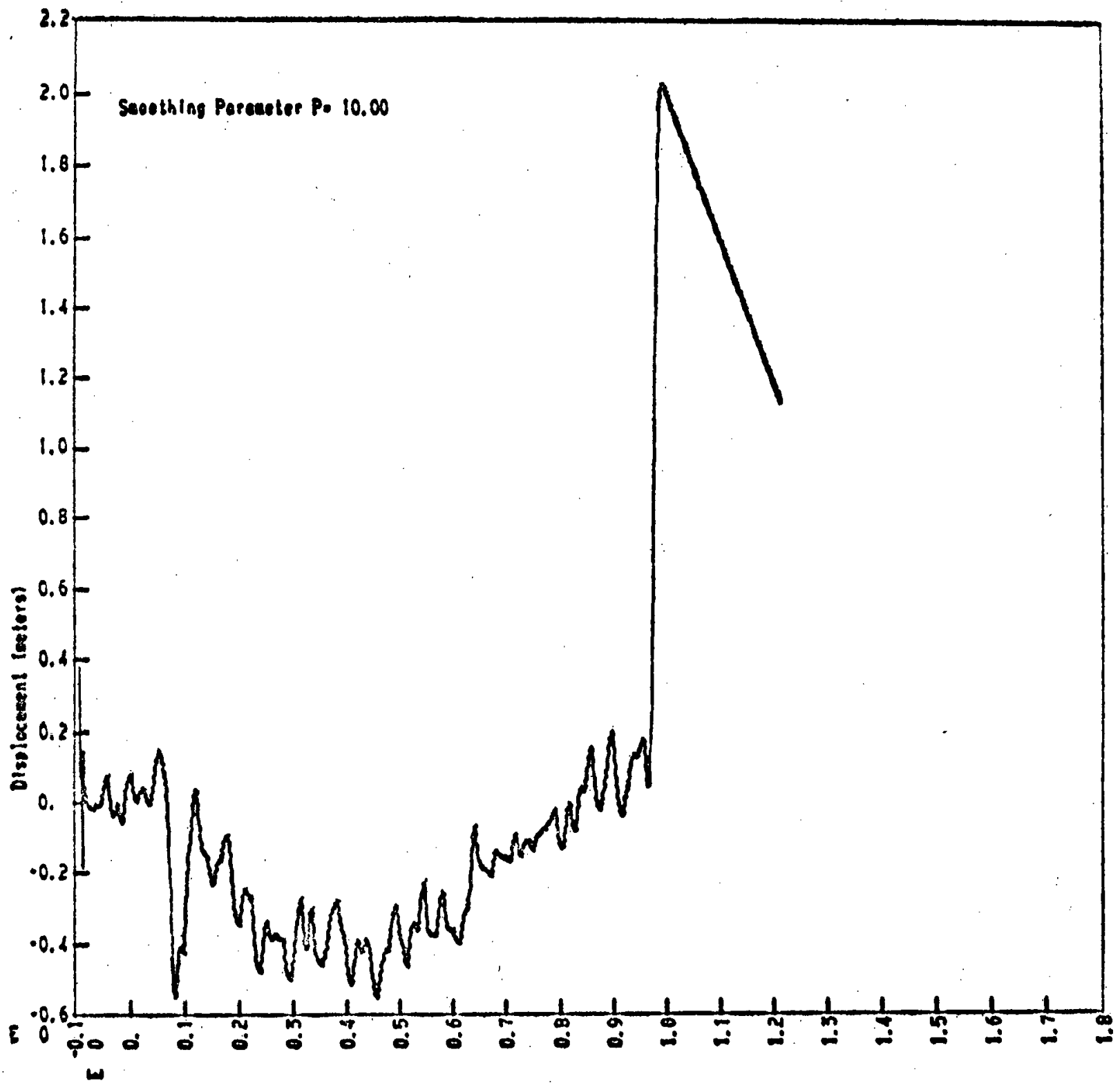

Piee lestol

FIGURE A-61

Horlzontel Displacement. Target 12

$-78-$ 


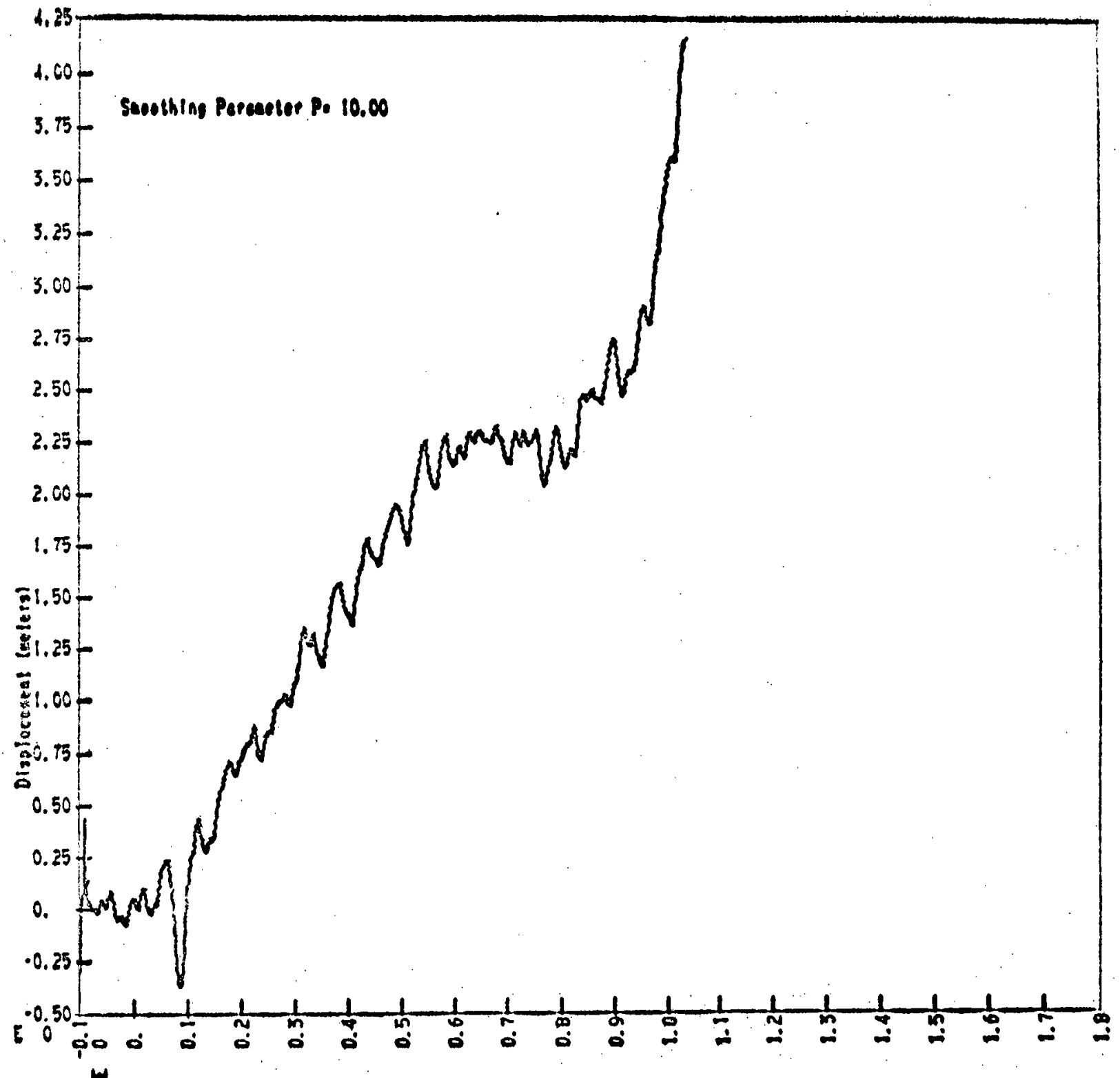

Ples loet.)

FIGURE A-62

Horlzontol Displacenent Target is

$-79-$ 


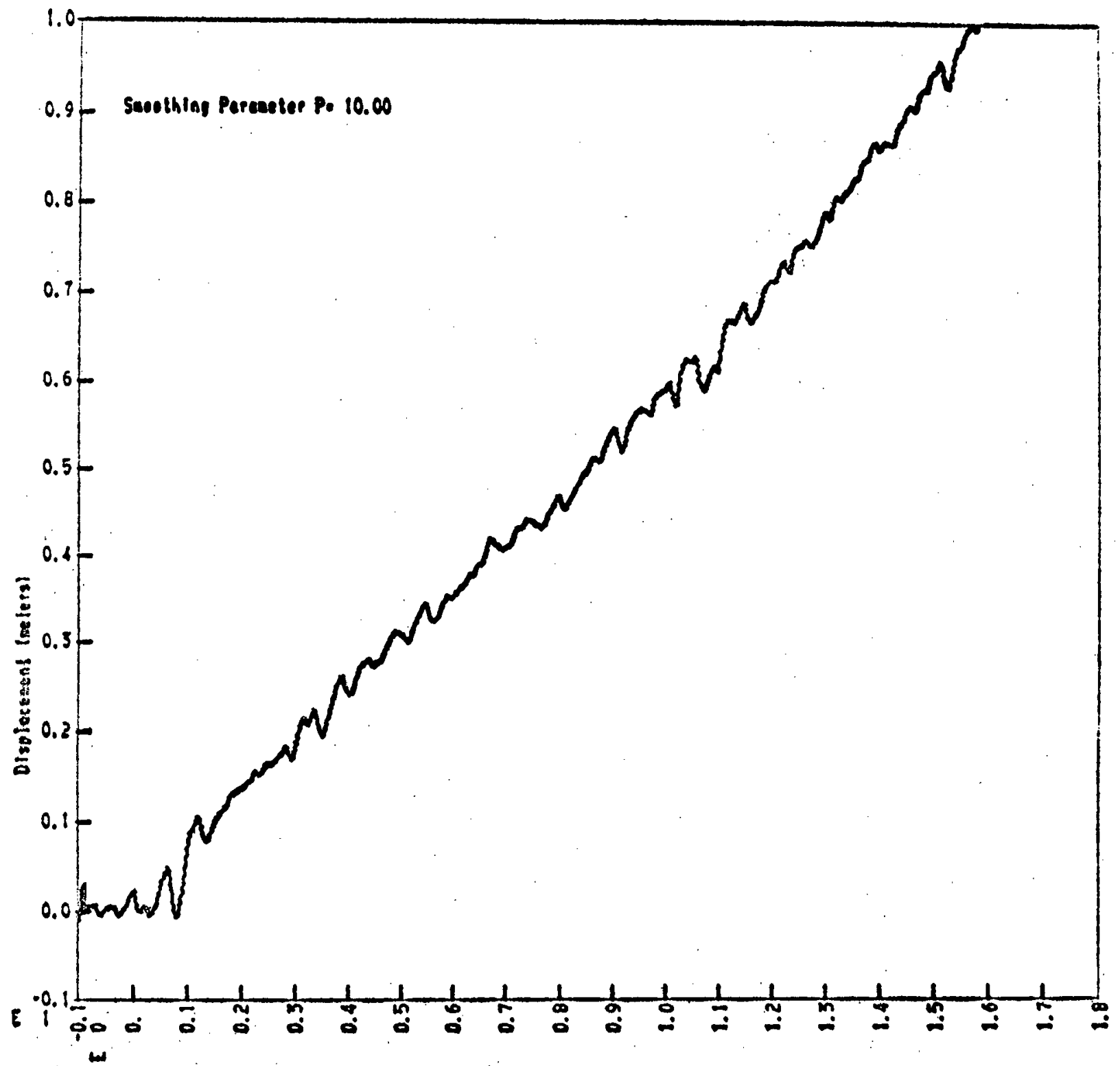

Plas (sec.)

FIGURE A-63

Hopizontal Displacement Torget it

$-80-$ 


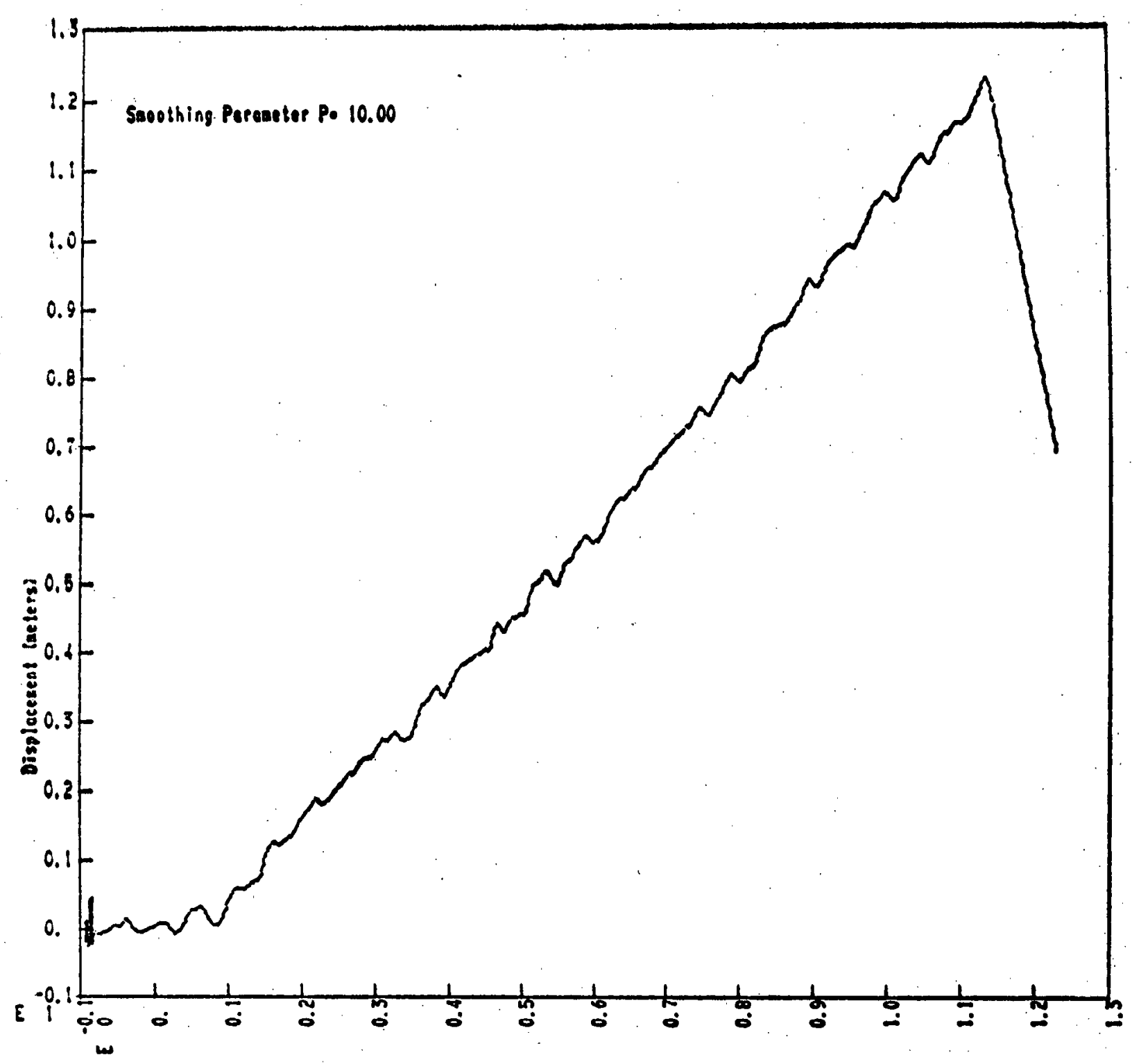

Tiase lsec.)

FIGURE A-64

Horizontal Displacement Target 15 


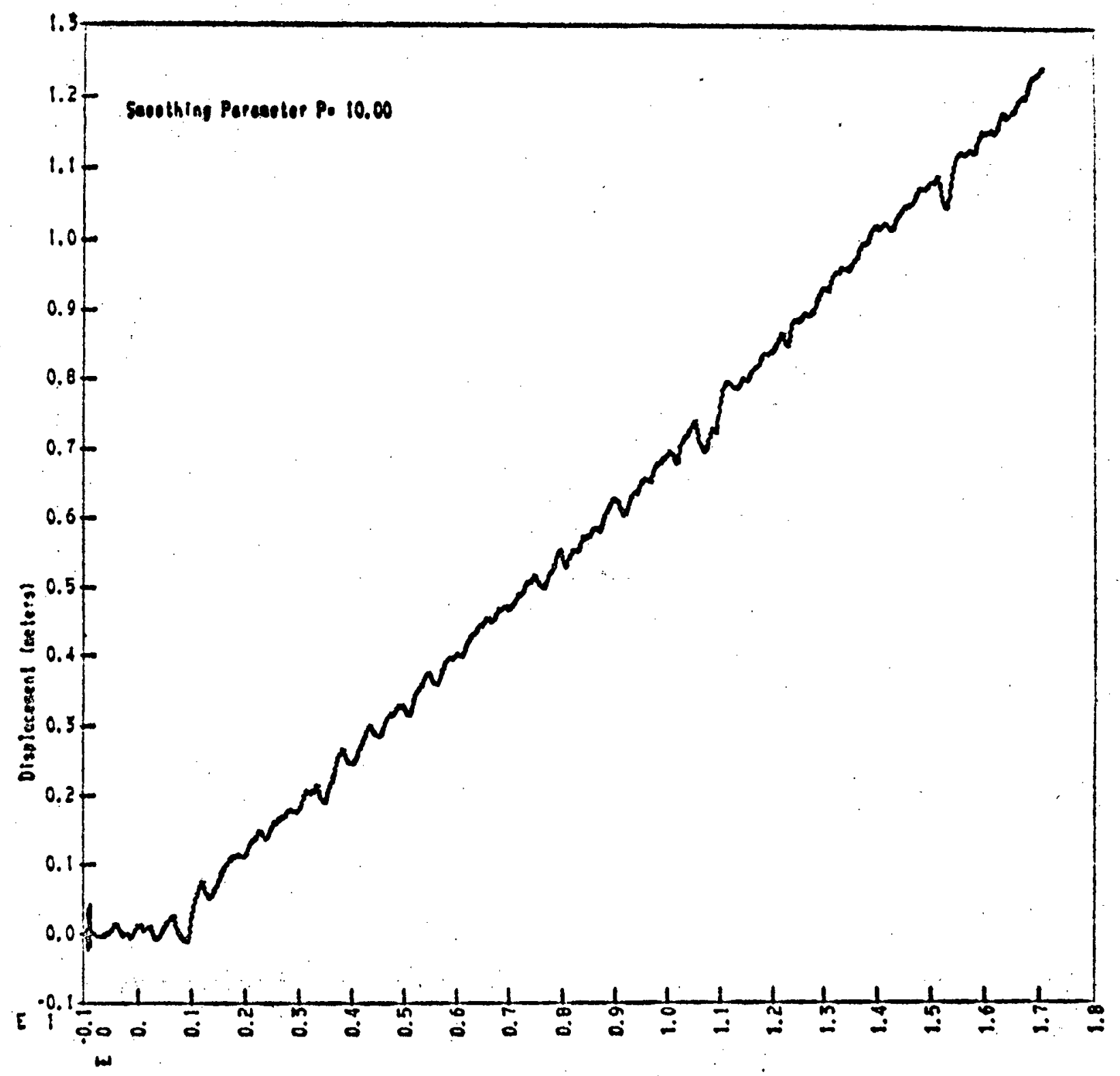

Tiae loes.l

FIGURE A-65

Horlzontol Digplacement Torget 16 


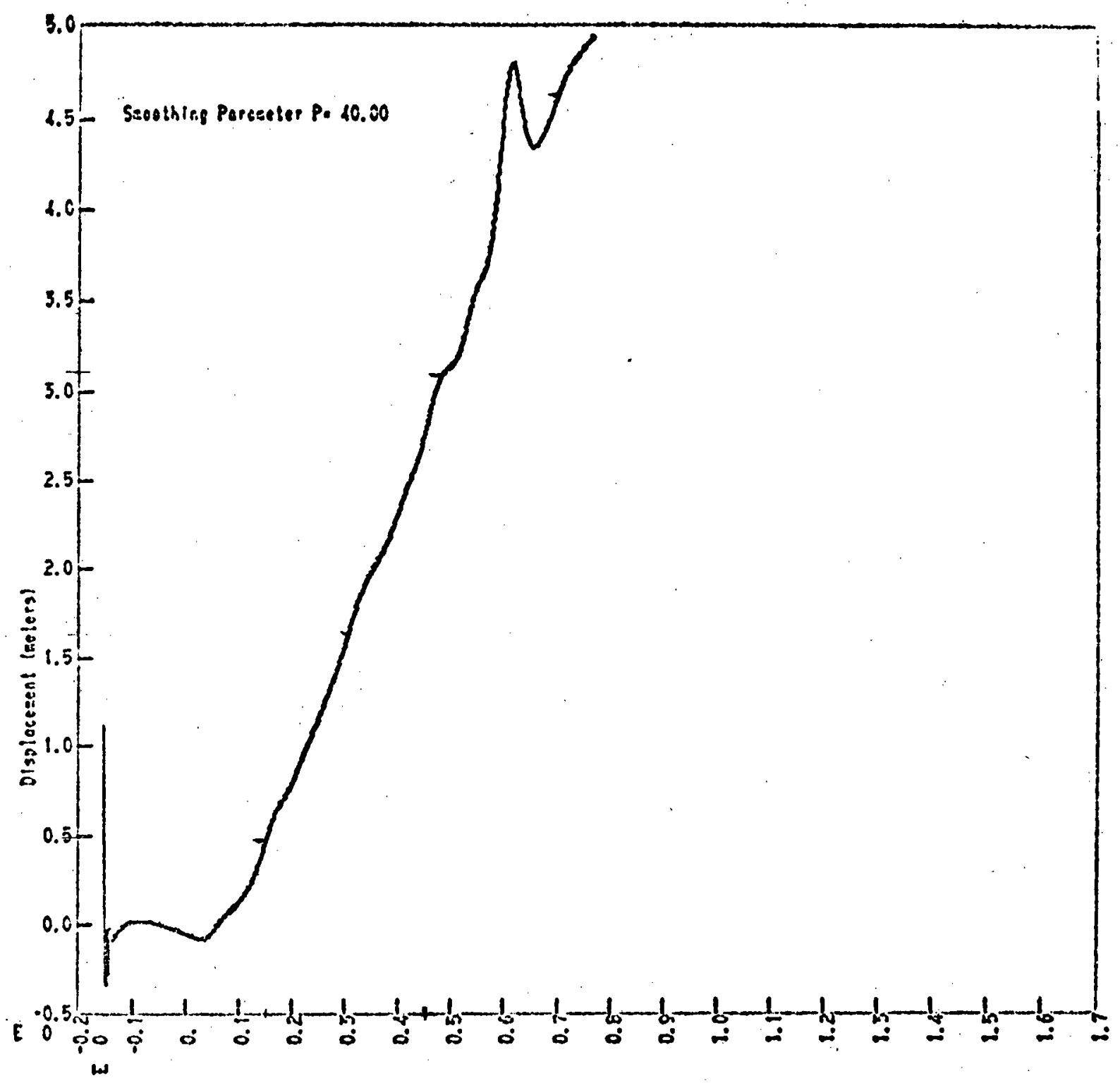

Tlee lset.)

\section{FIGURE A-66}

Veptlical Displocentient Target 17 Cross Array 


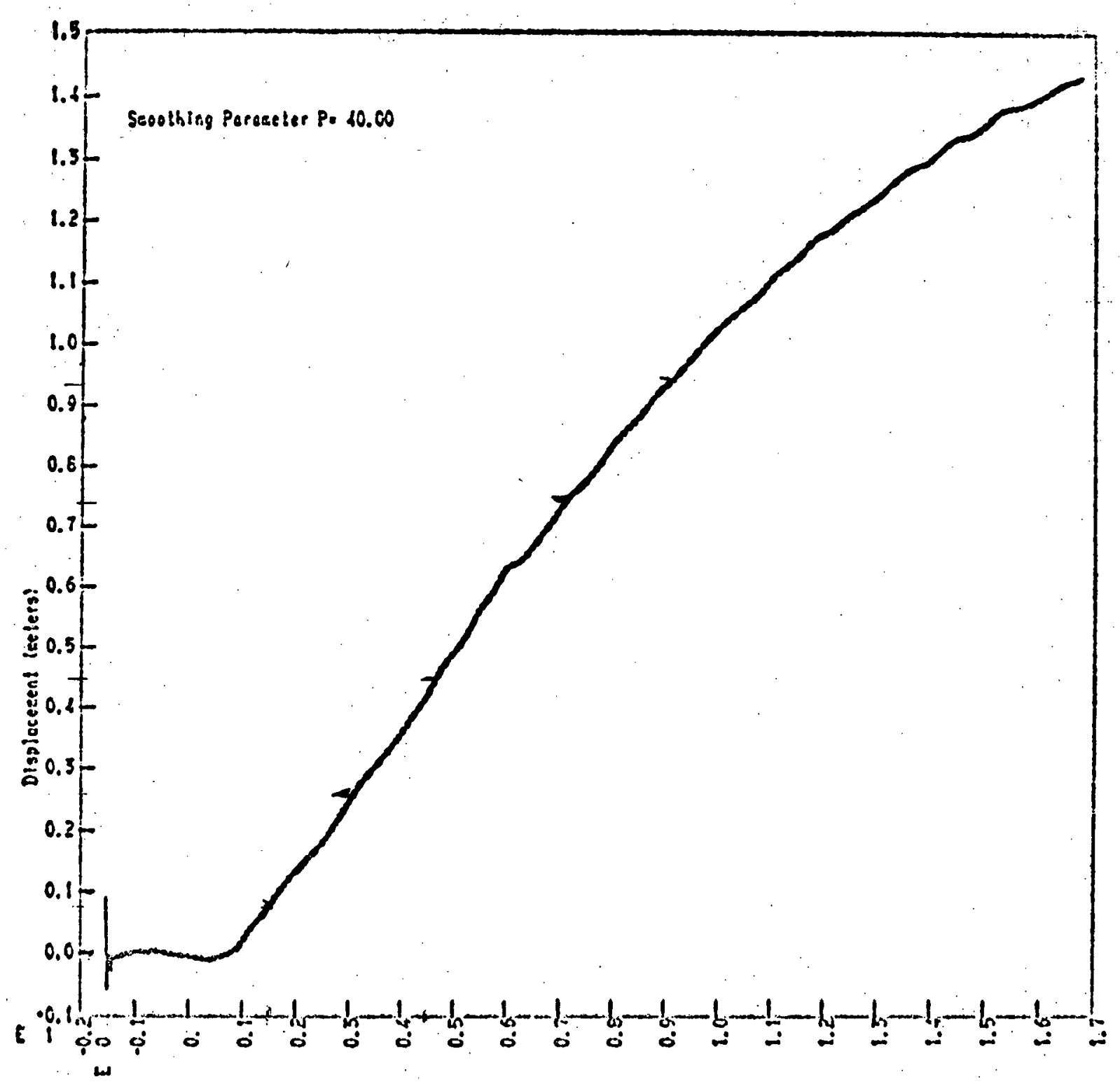

Tres (sec.)

FIGURE A-67

Vertical Displacement Target 18 Cross Array

$-84-$ 


$$
D
$$




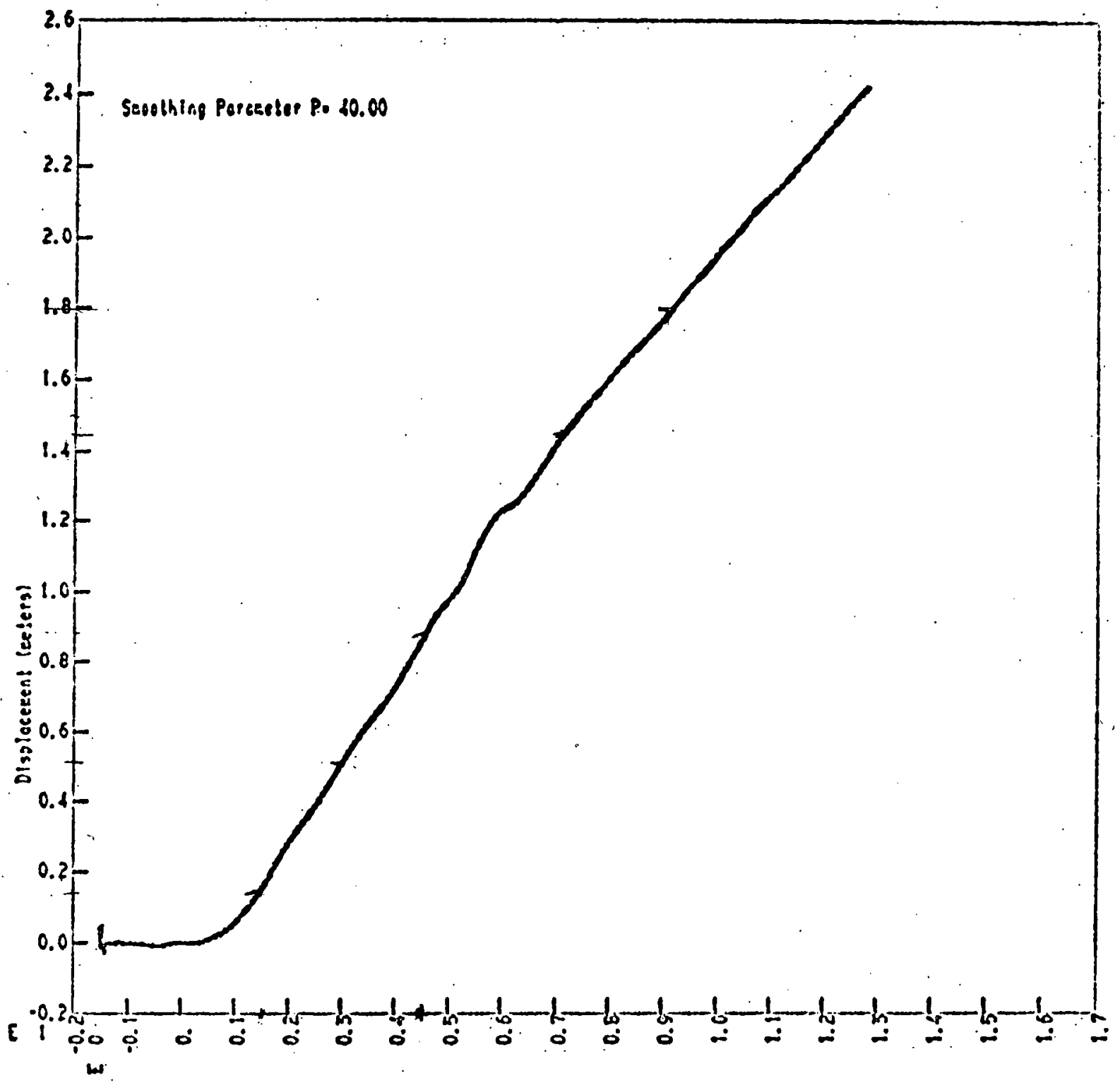

Pies lies.)

FIGURE A-69

Vertical Displacement Target 20 Cross Array

$-86-$ 


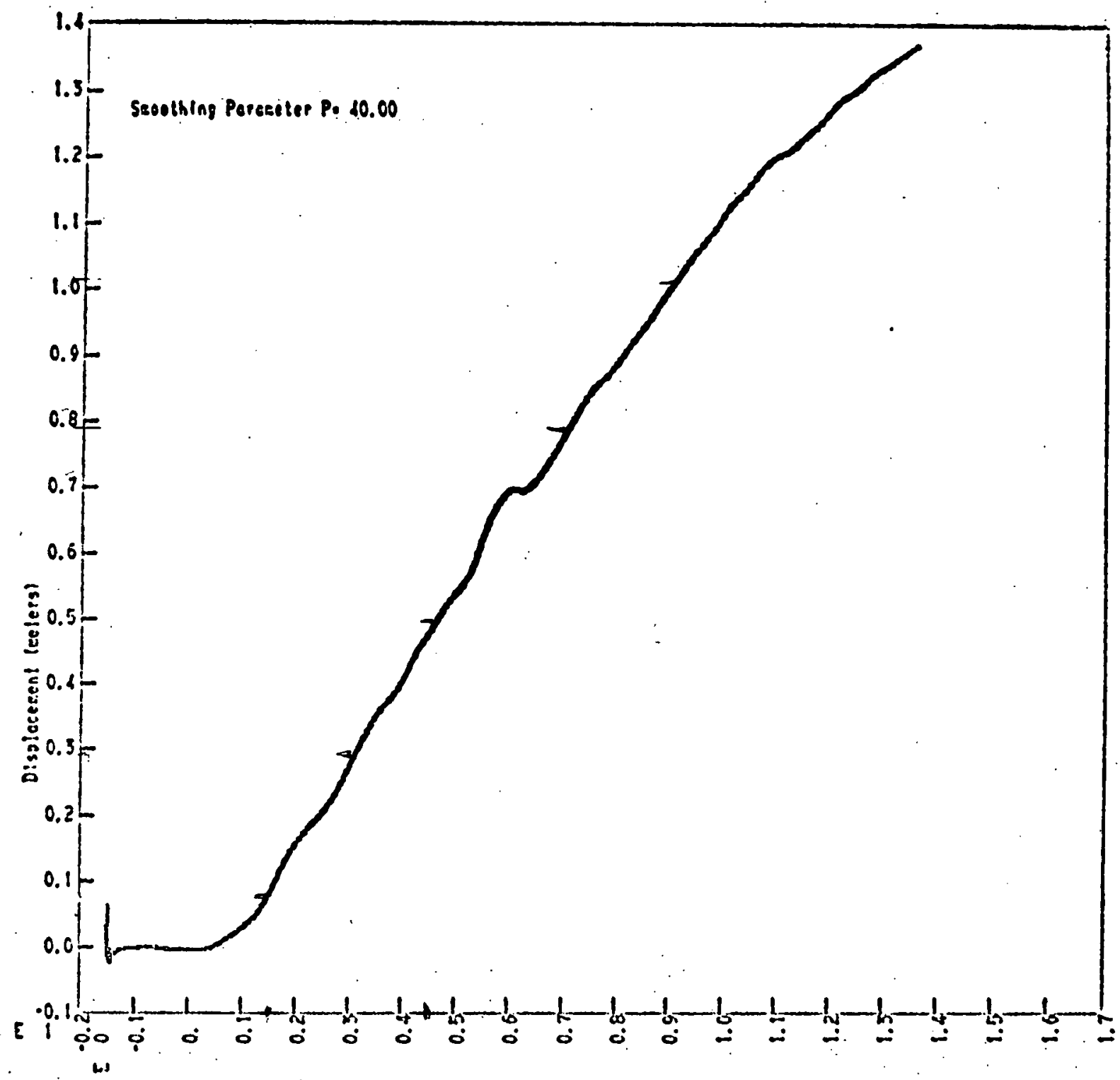

TIa Isecel

FIGURE A-70

Vertical Displacement Target 21 Cross Array

$-87-$ 


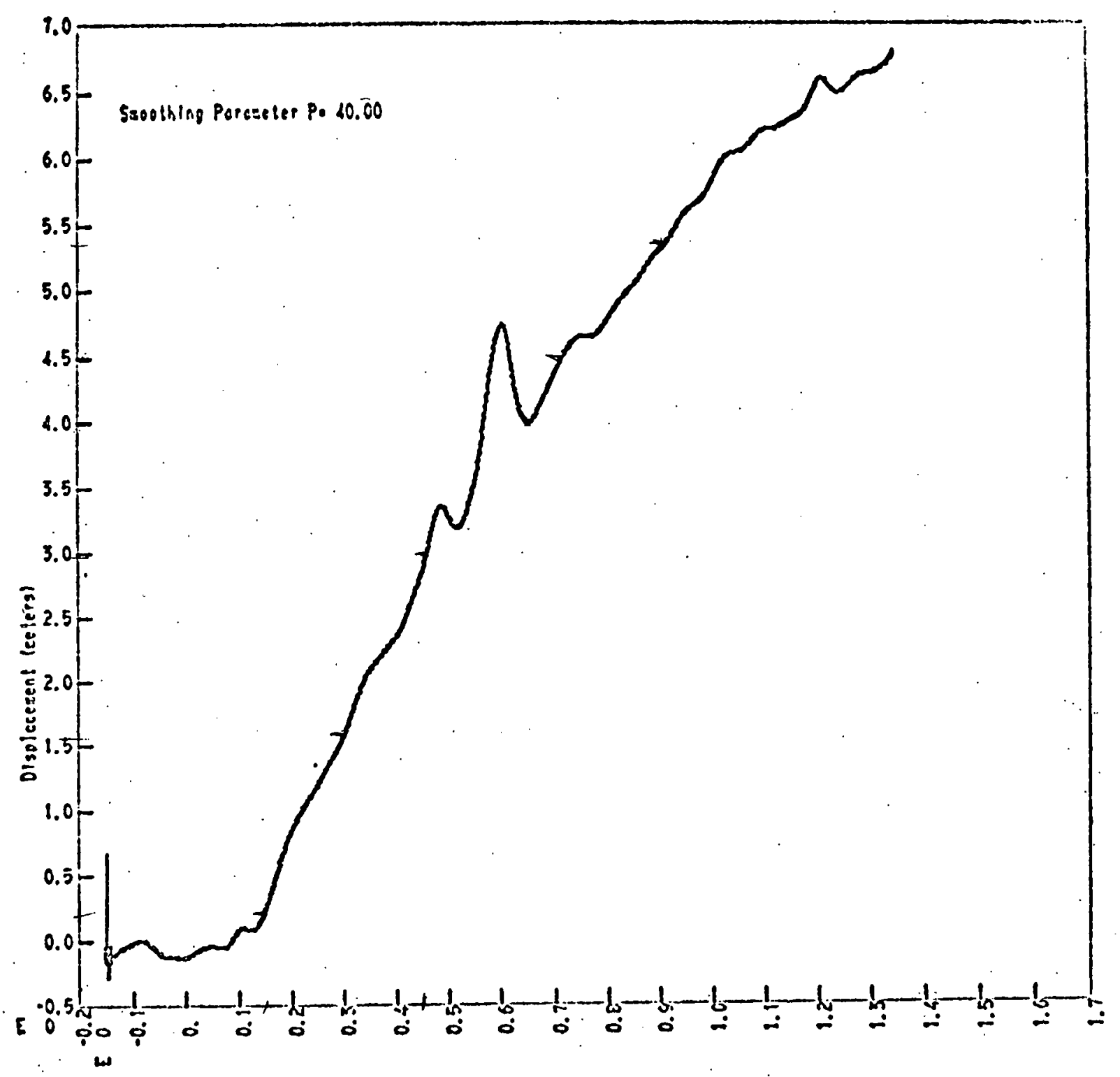

Tles (sec.)

FIGURE A-71

Yerticol Displacement Torget 22 Cross Array. 


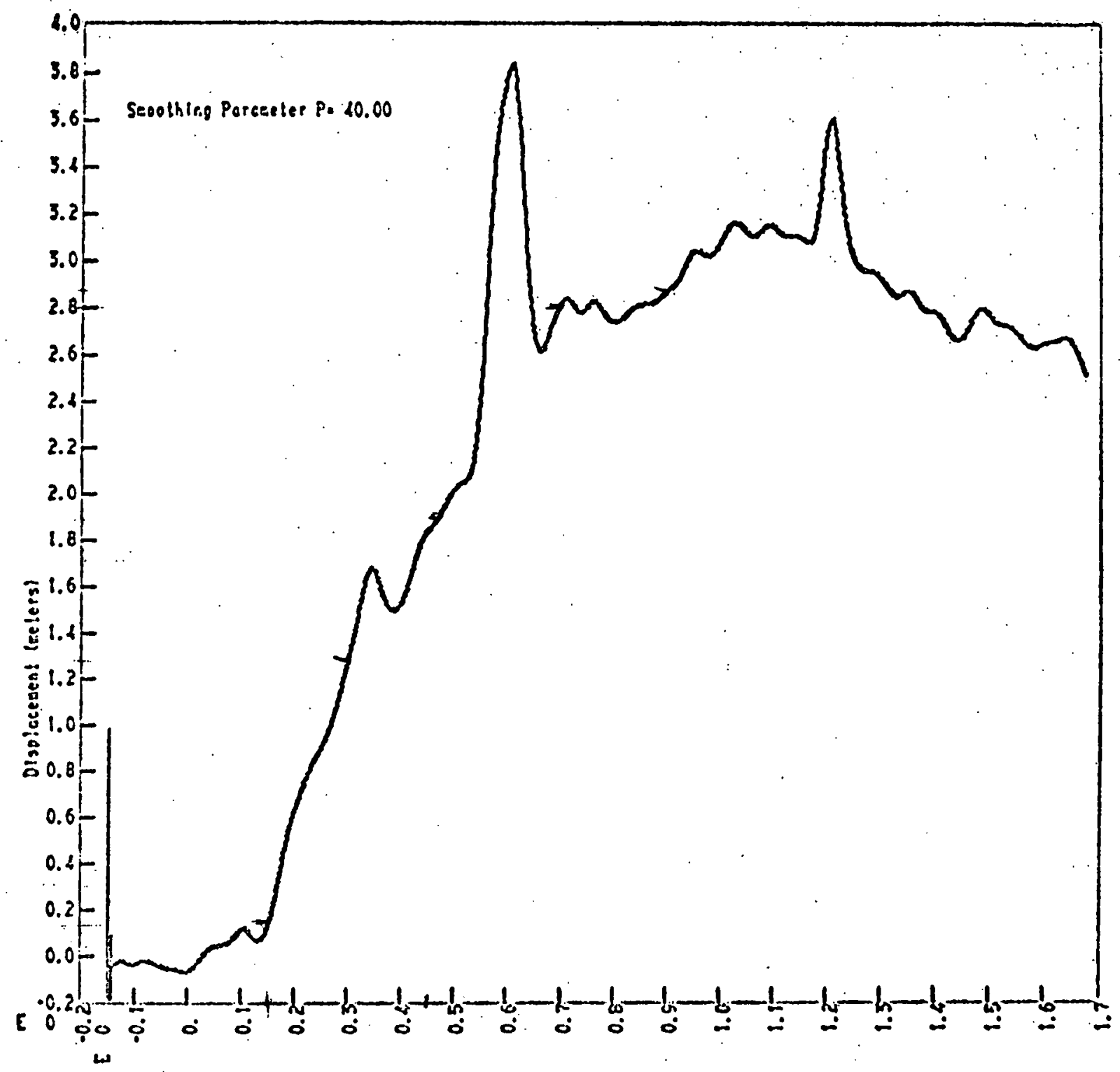

Plee loee.

FIGURE A-72

Vertical Displacement Target 23 Cross Array 


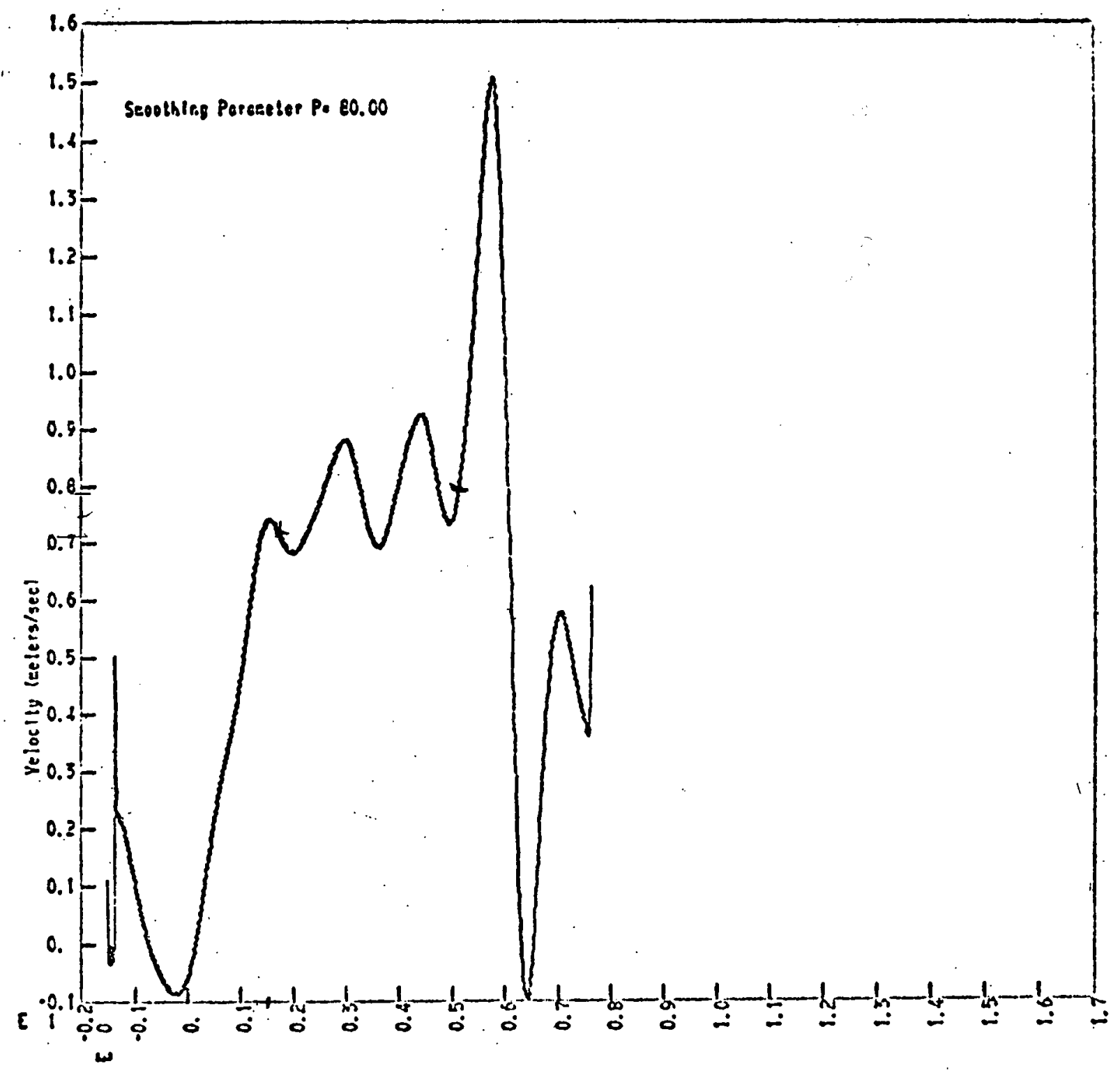

Tlee loze.l

FIGURE A-73

Yertical Velocity. Torget 17 Cross Array

$-90-$ 


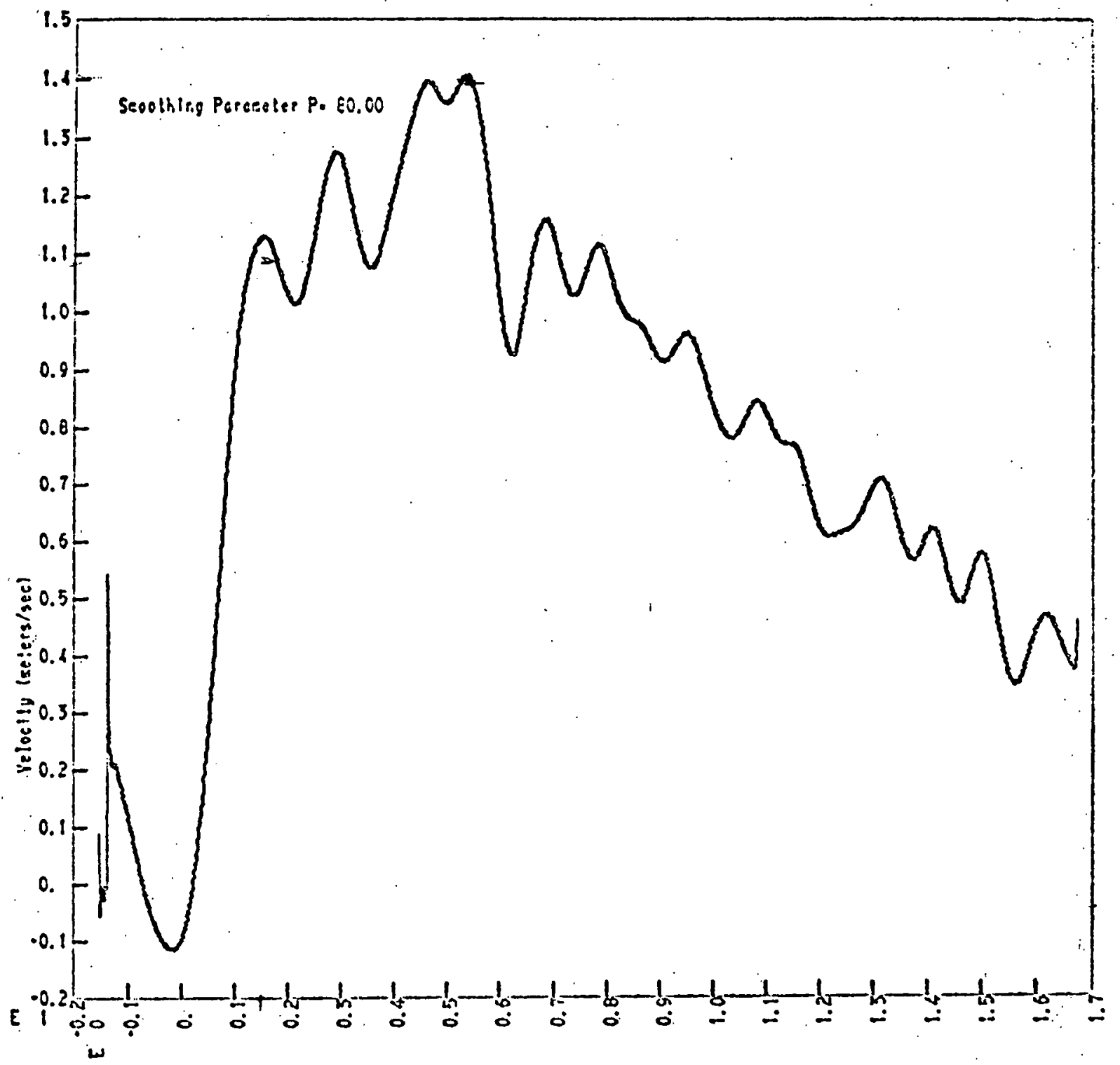

Tiae iser.)

FIOULRE A-74

Vertical Velocity Targe! 18. Cross Array

-91- 


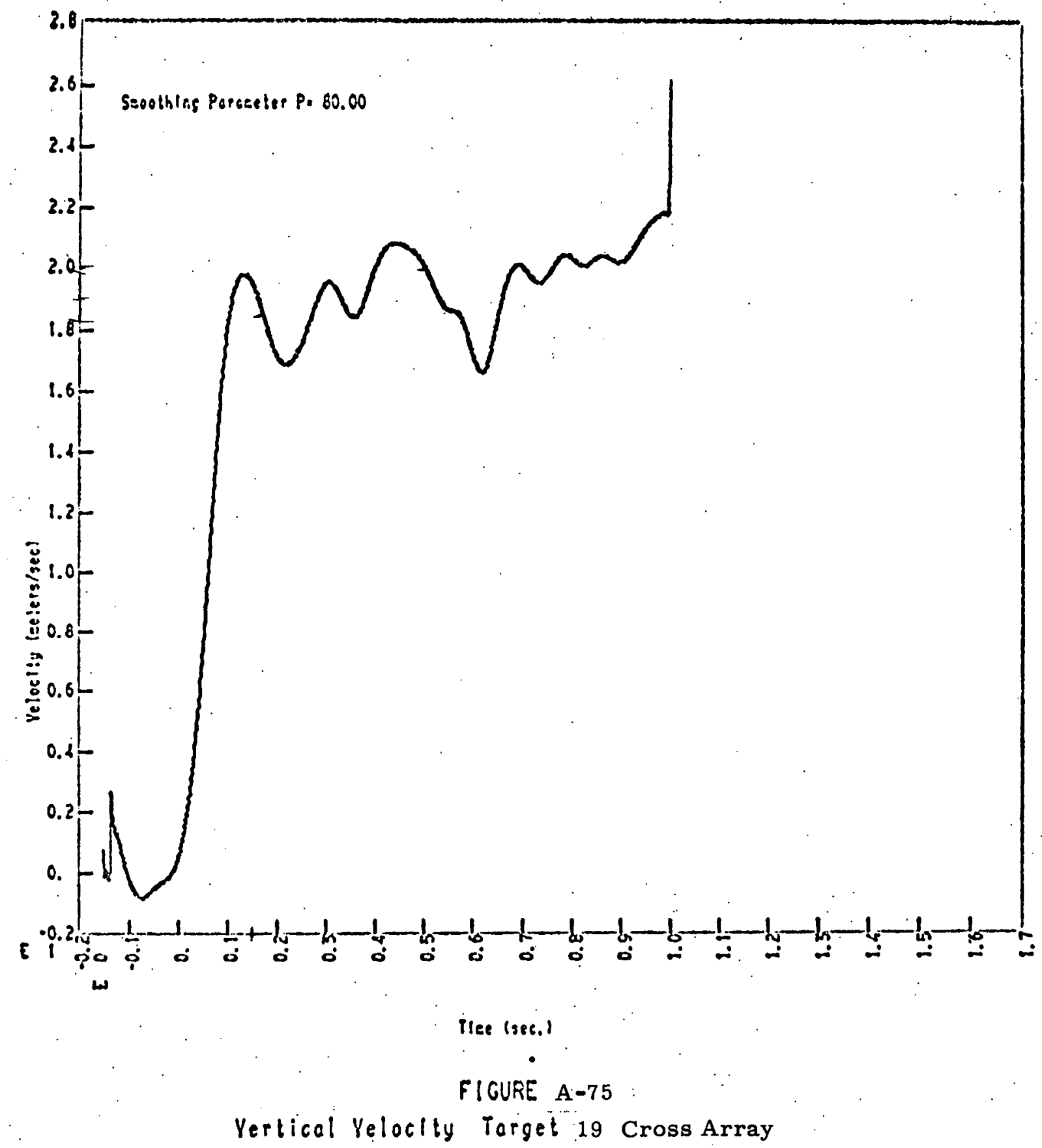

$-92-$ 


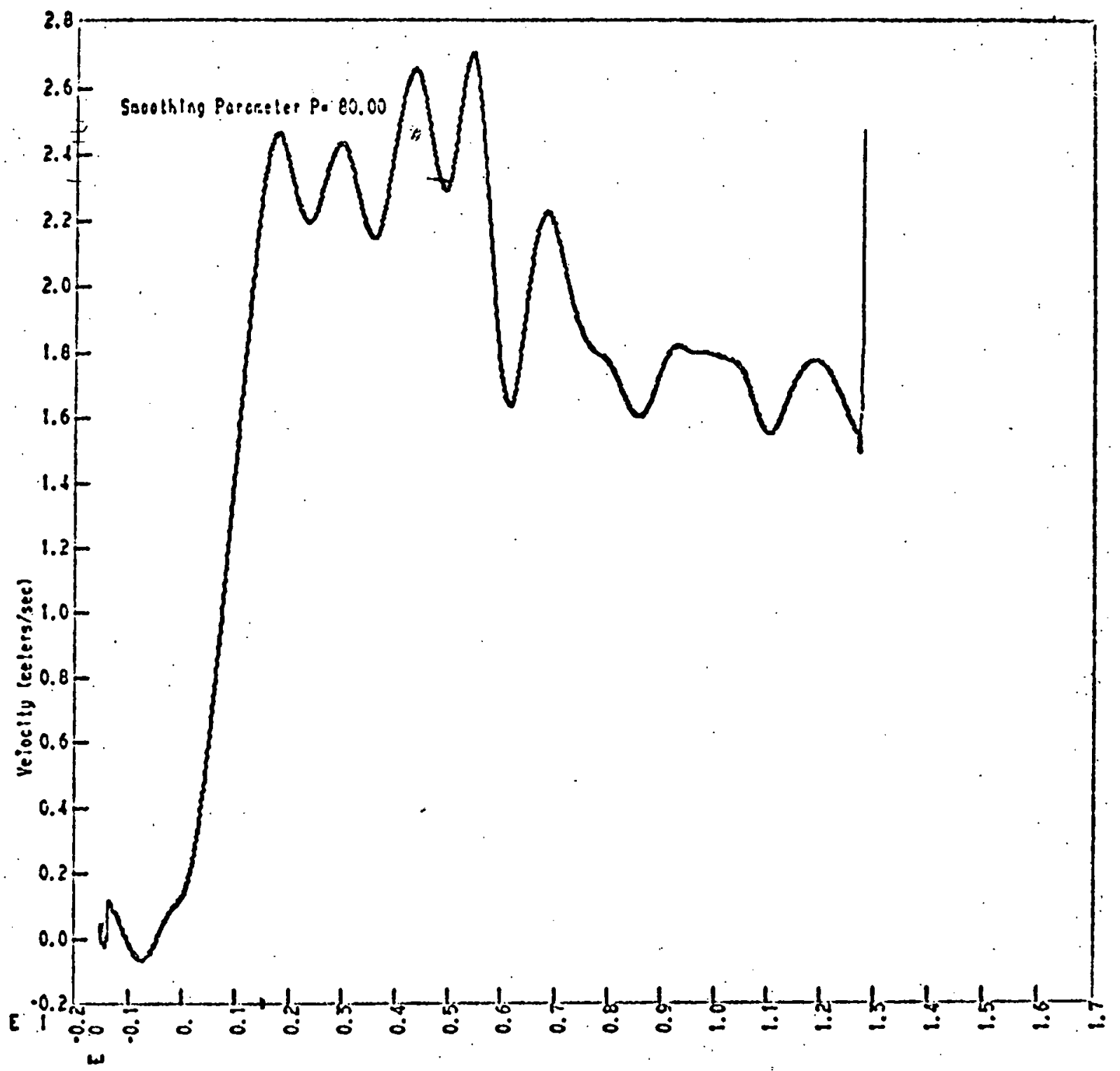

Plee lsec.

FIGURE A-76

Vertical Veloclty Target 20 Cross.Array

$-93-$ 


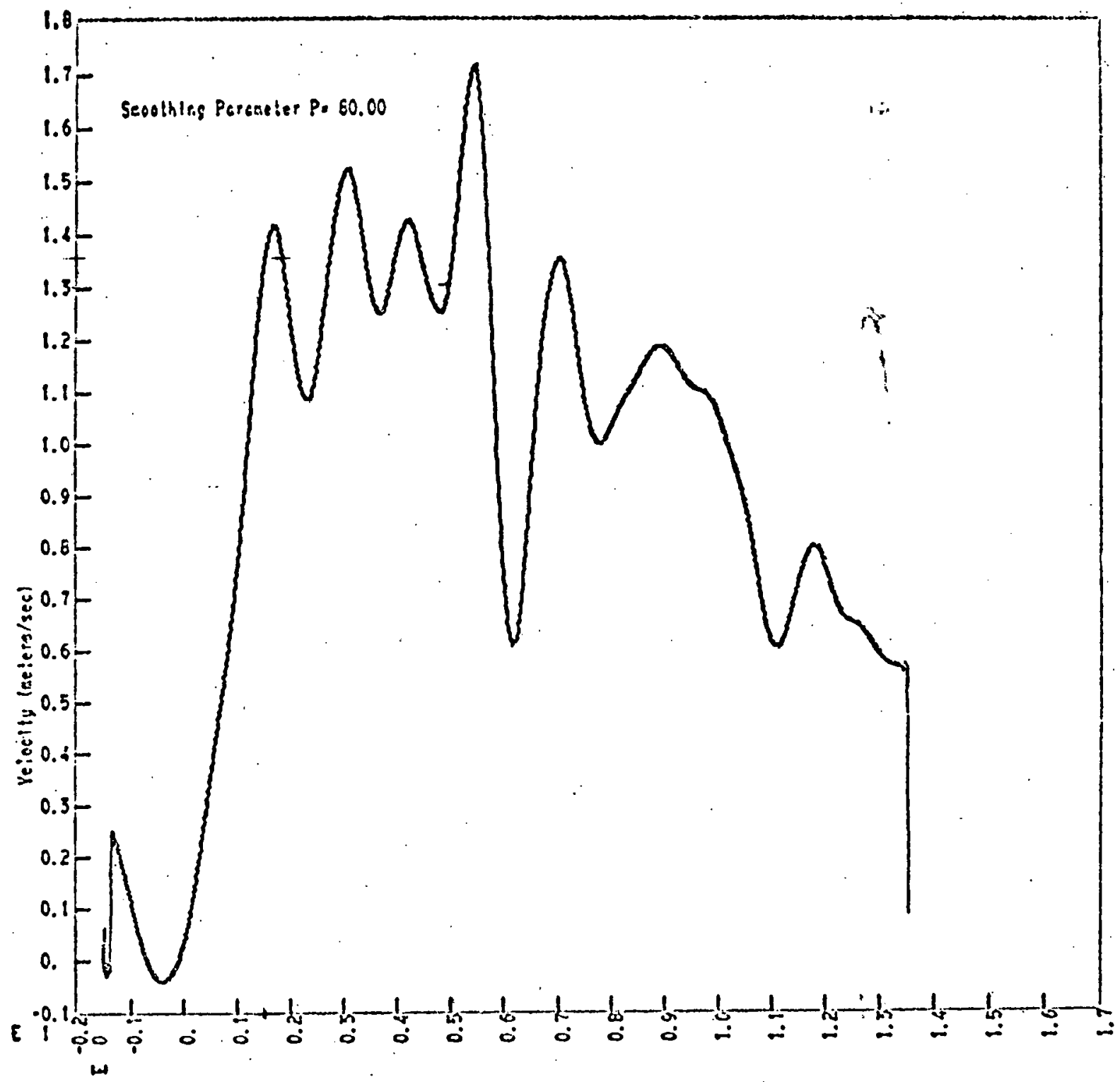

Flee loses.)

FIGURE A-77

Vertical Velocity Target 21 Cross Array : 9

$-94-$ 


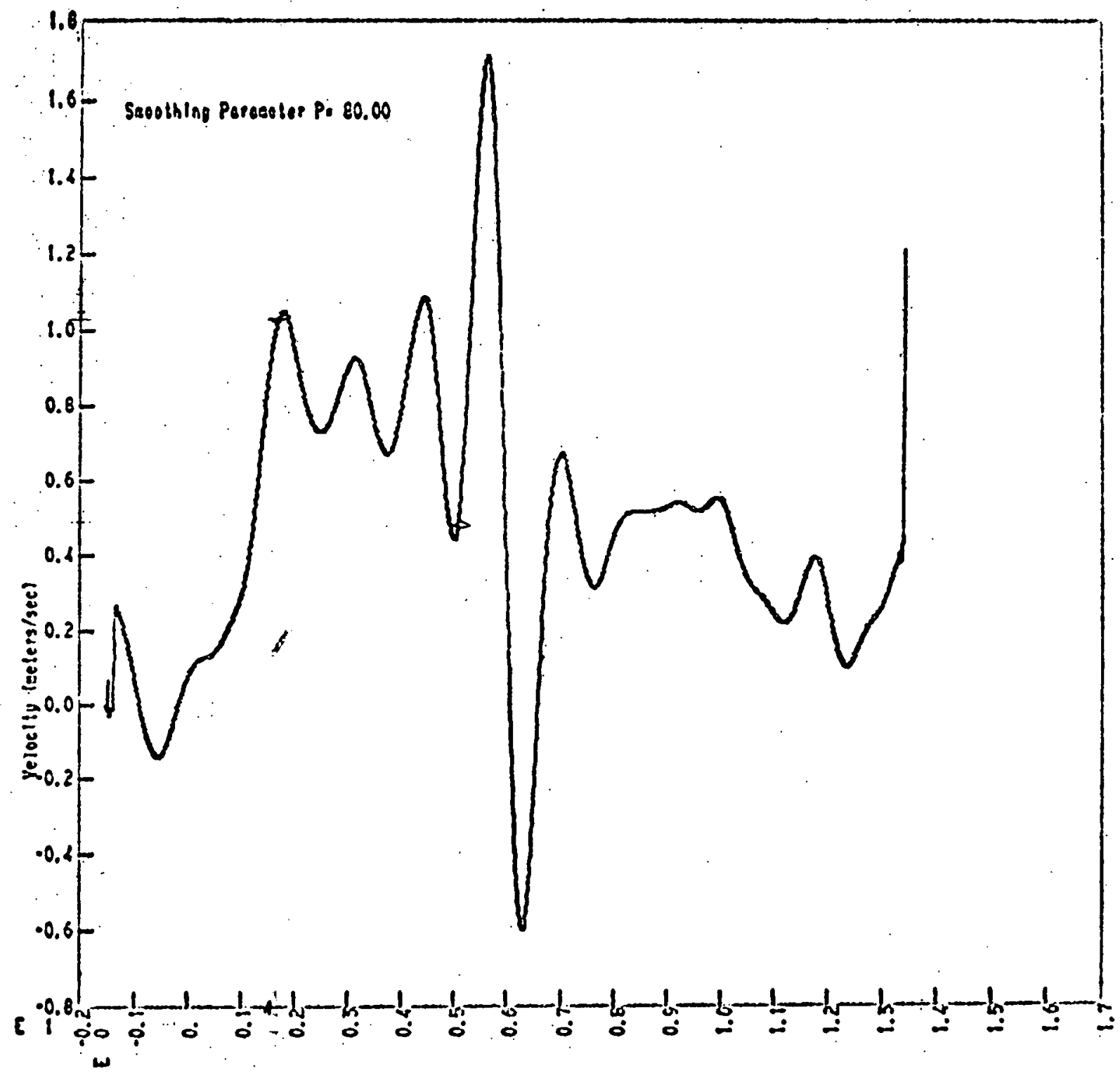

PIe sec.)

FIGURE A-78

Vertical Velocity Target 22 Cross Array

$-95-$ 


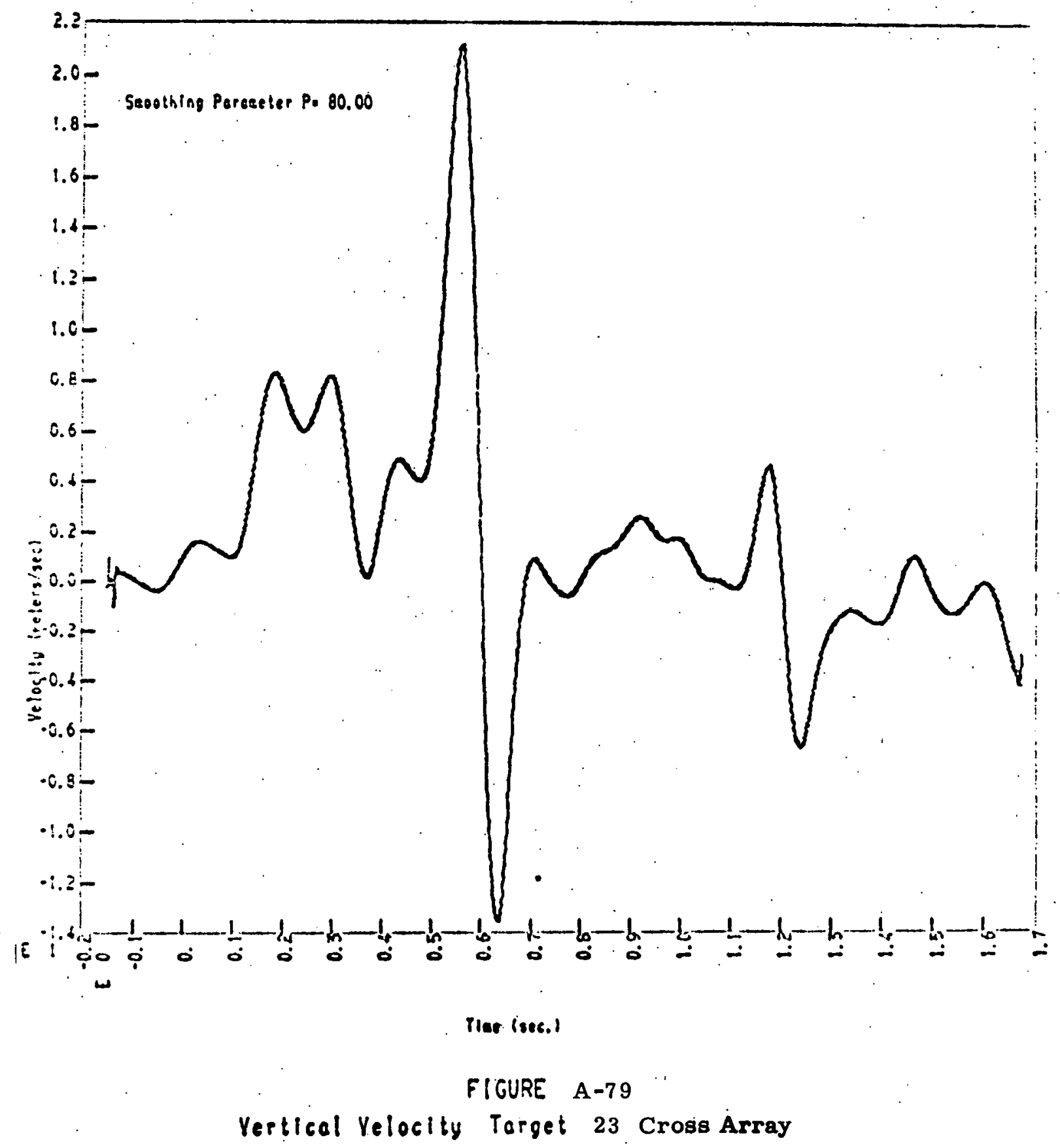

$-96-$ 


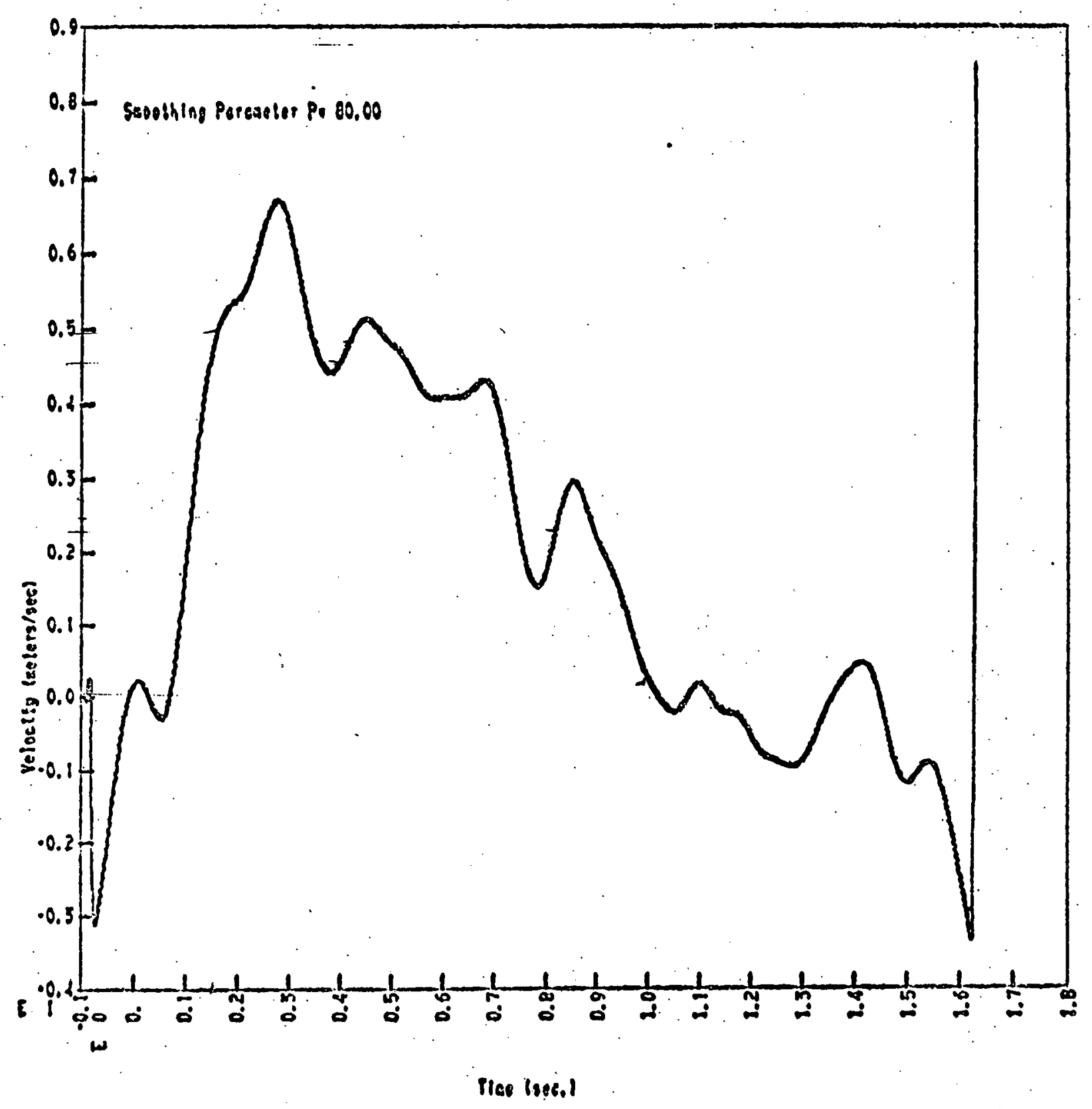

FIGURE A -80

Vertleal Yelocity Target 1

$-97-$ 


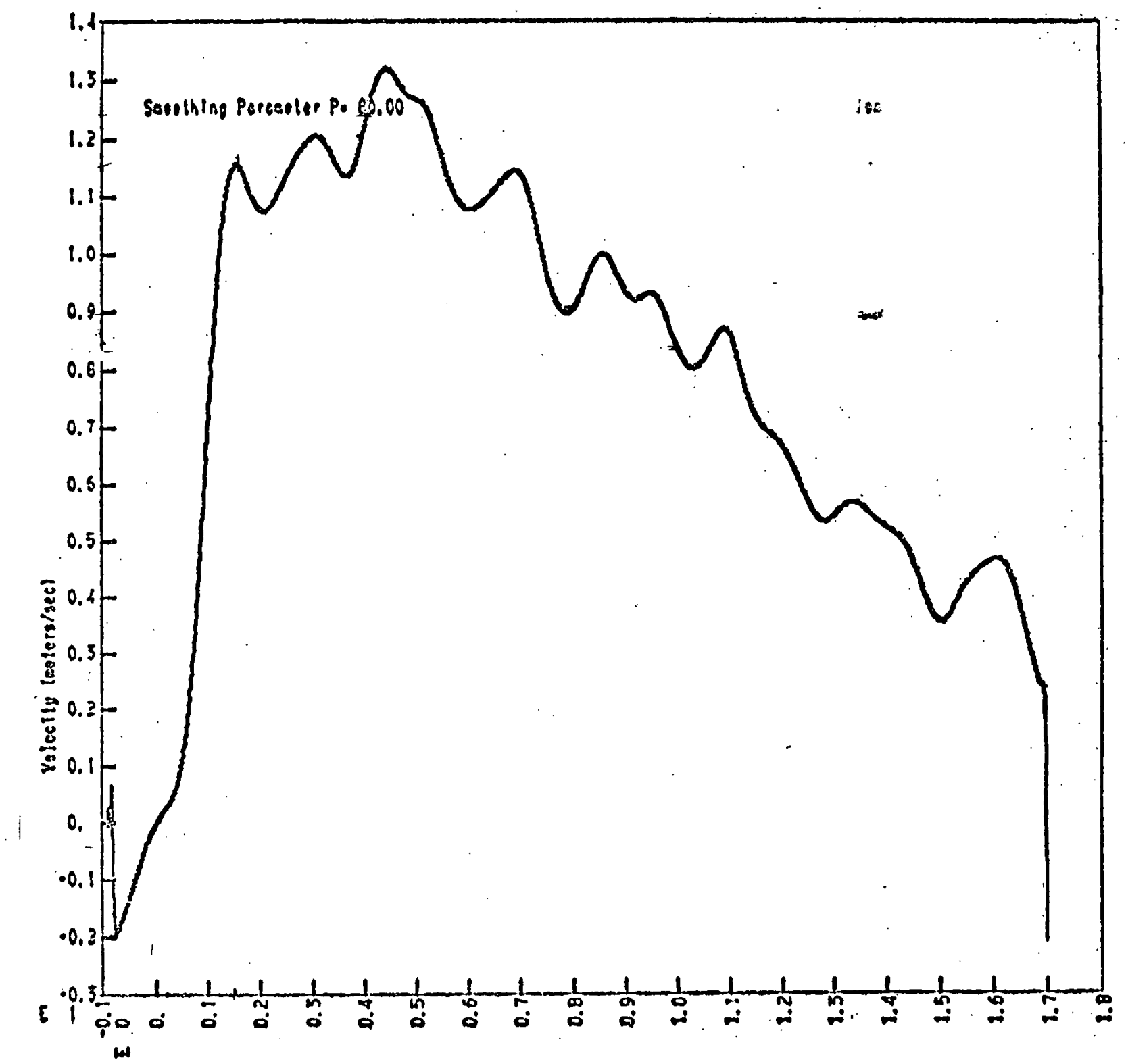

Plese lsac.!

FIGURE A-81

Veptlcal Velocity Target

78

$-98-$ 


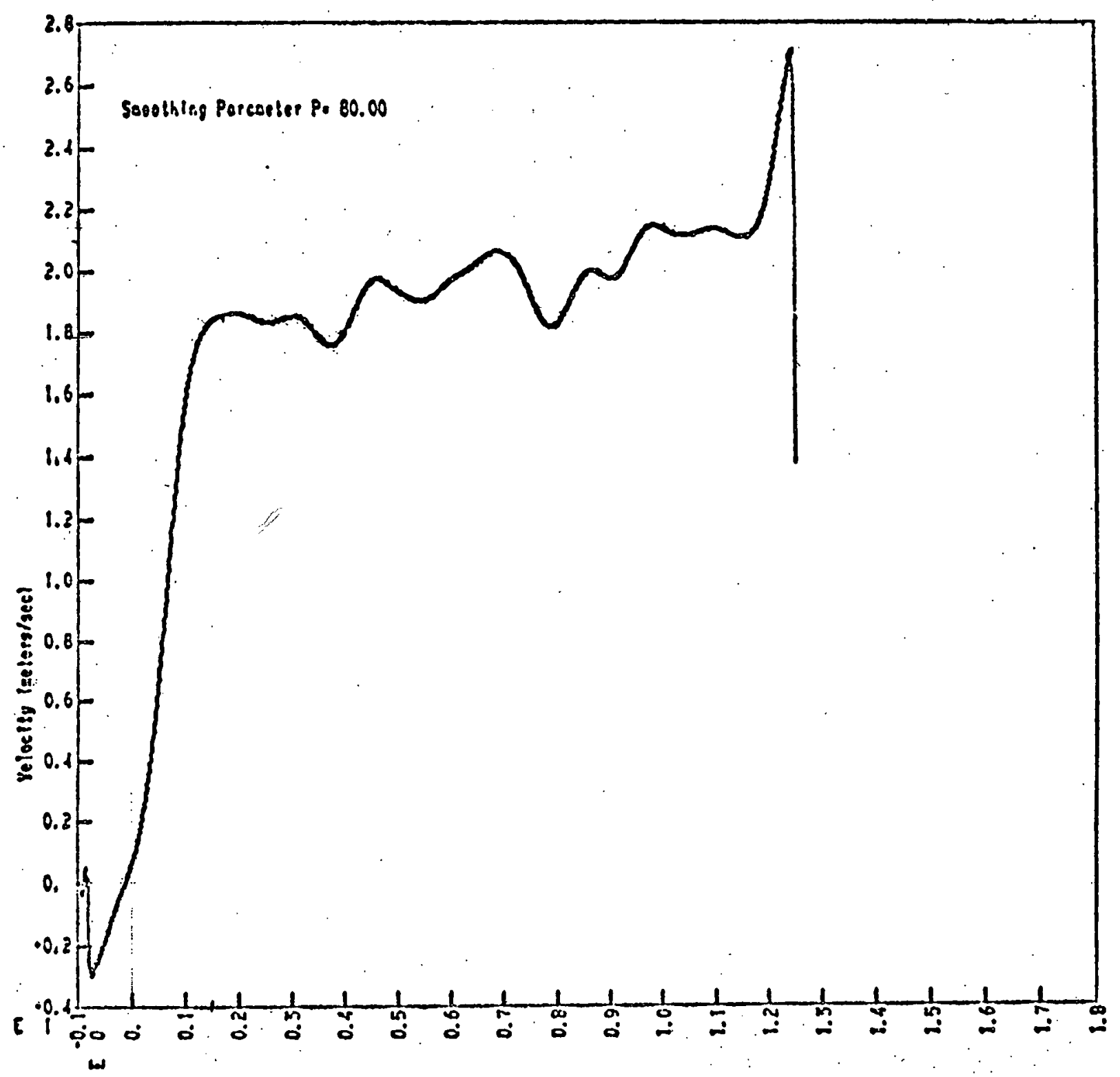

Ploo lyec.)

FI GURE A-82

Yerbical Yelocily Target 3 


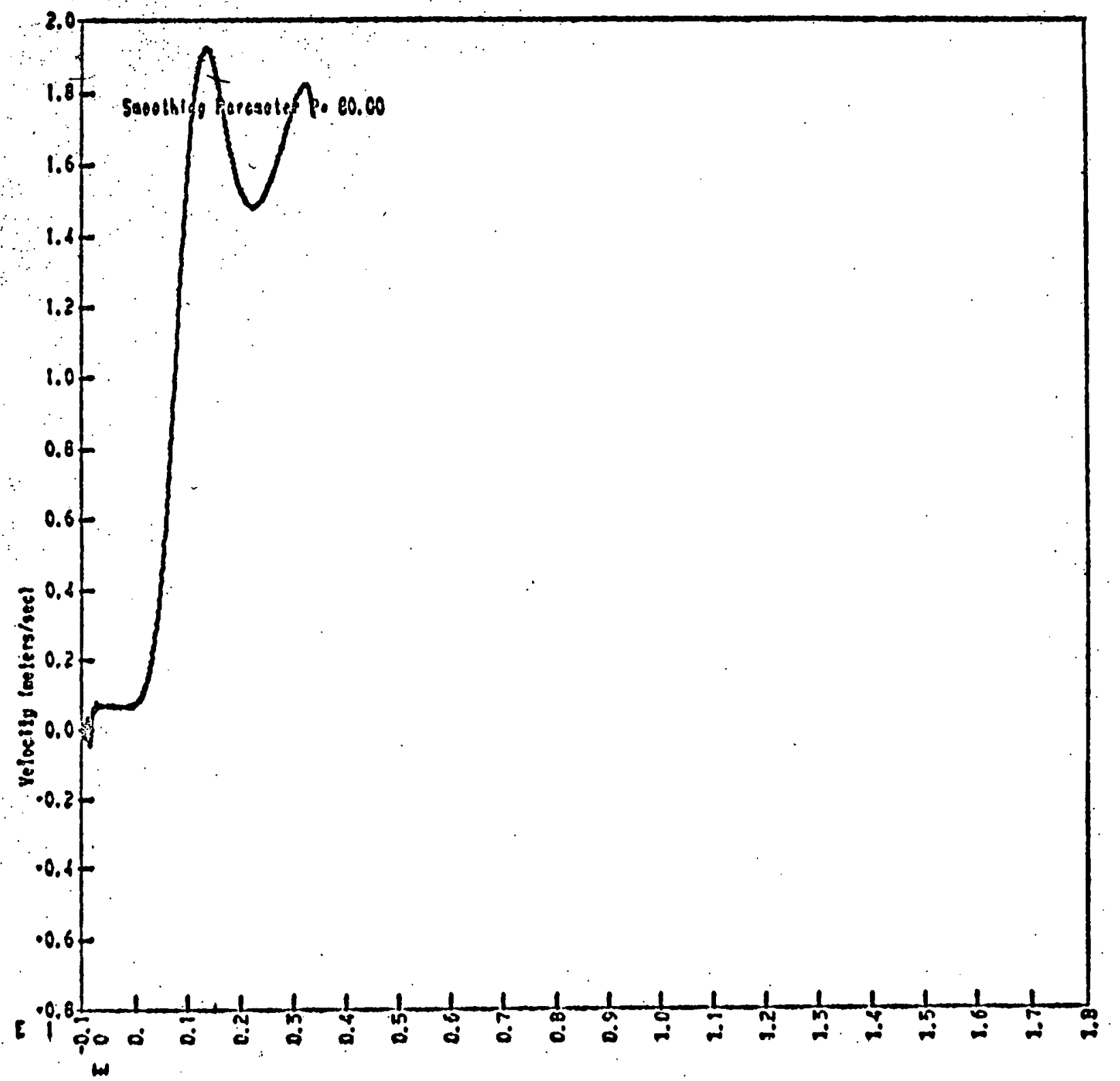

fice lise,

FIGURE A-83

Yorticol Yelocity. Torget a

$-100-$ 


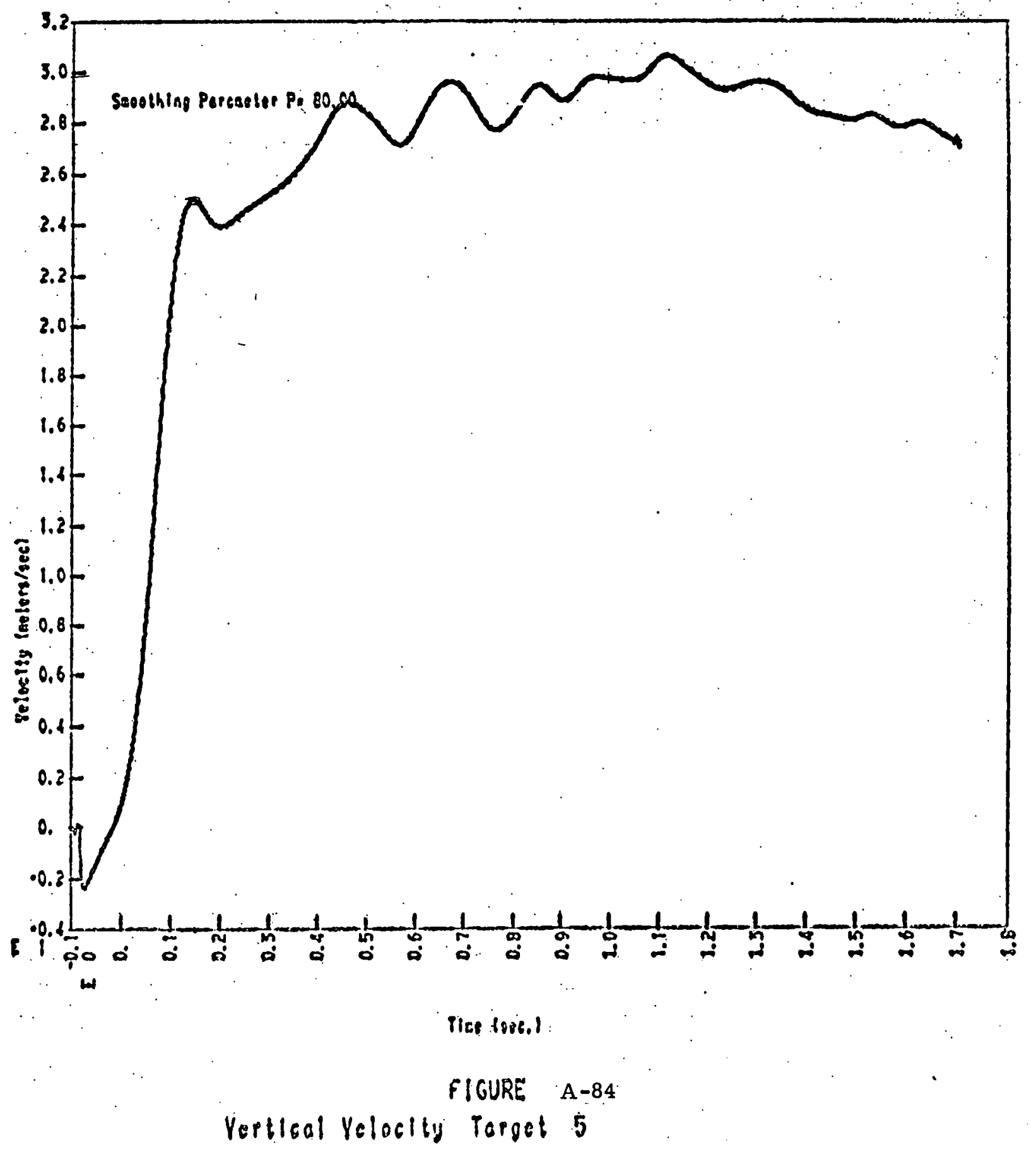

$-101-$ 


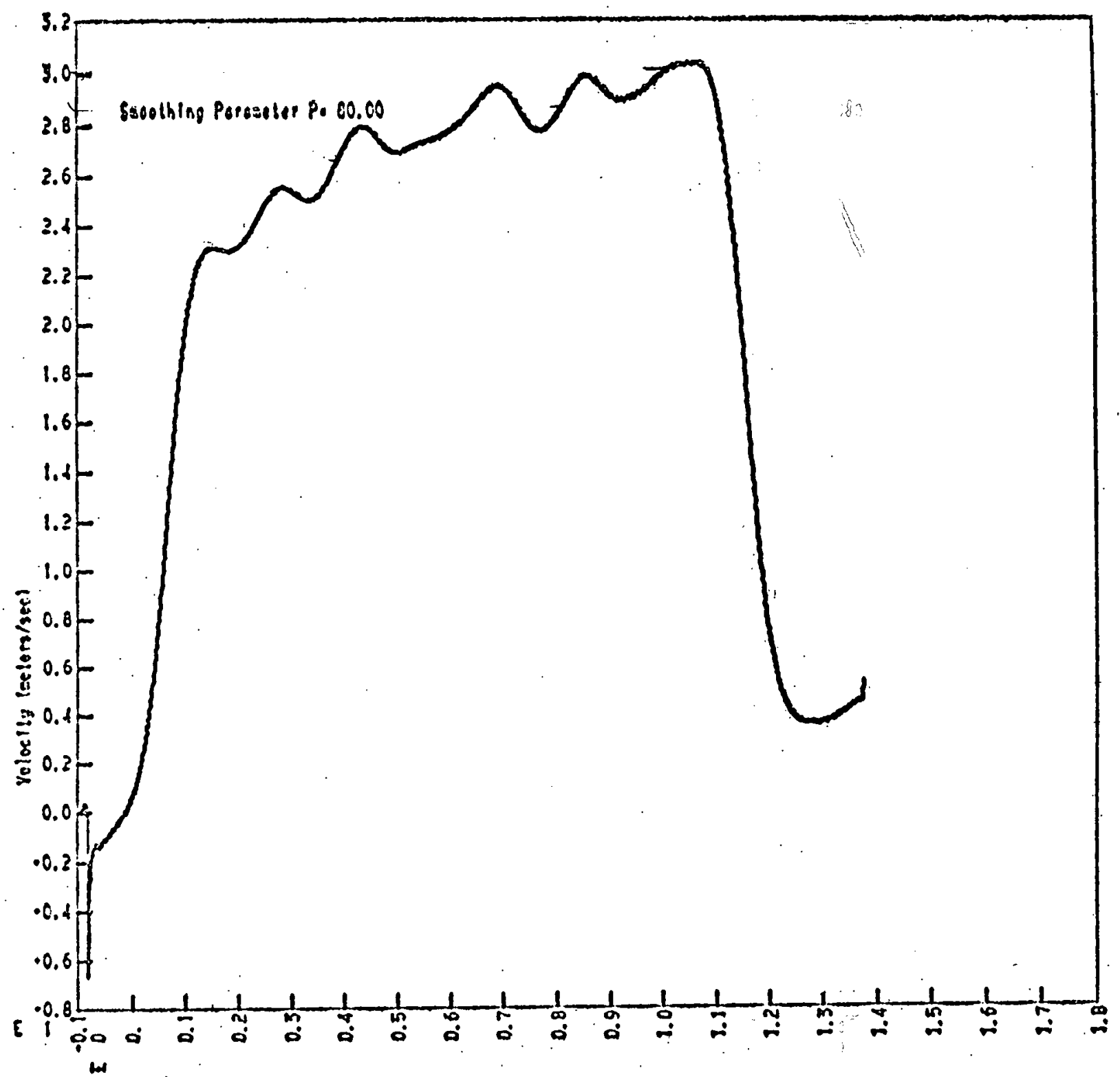

Pleo liec,

FIGURE A-85

Yertical Yoloetly Targat 6

$-102-$ 


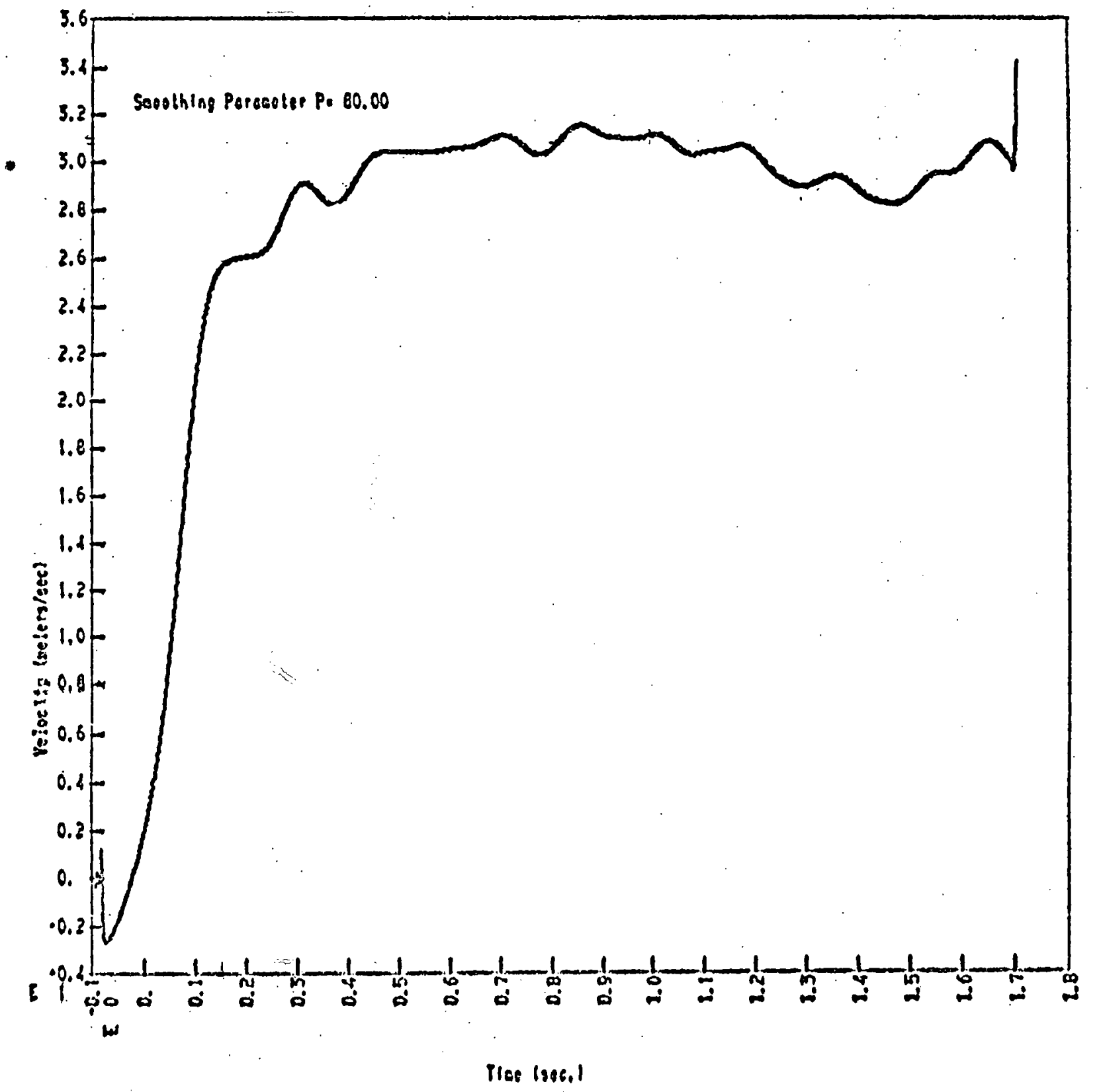

FIGURE A-86

Vertlesel Velocity Target?

$-103-$ 


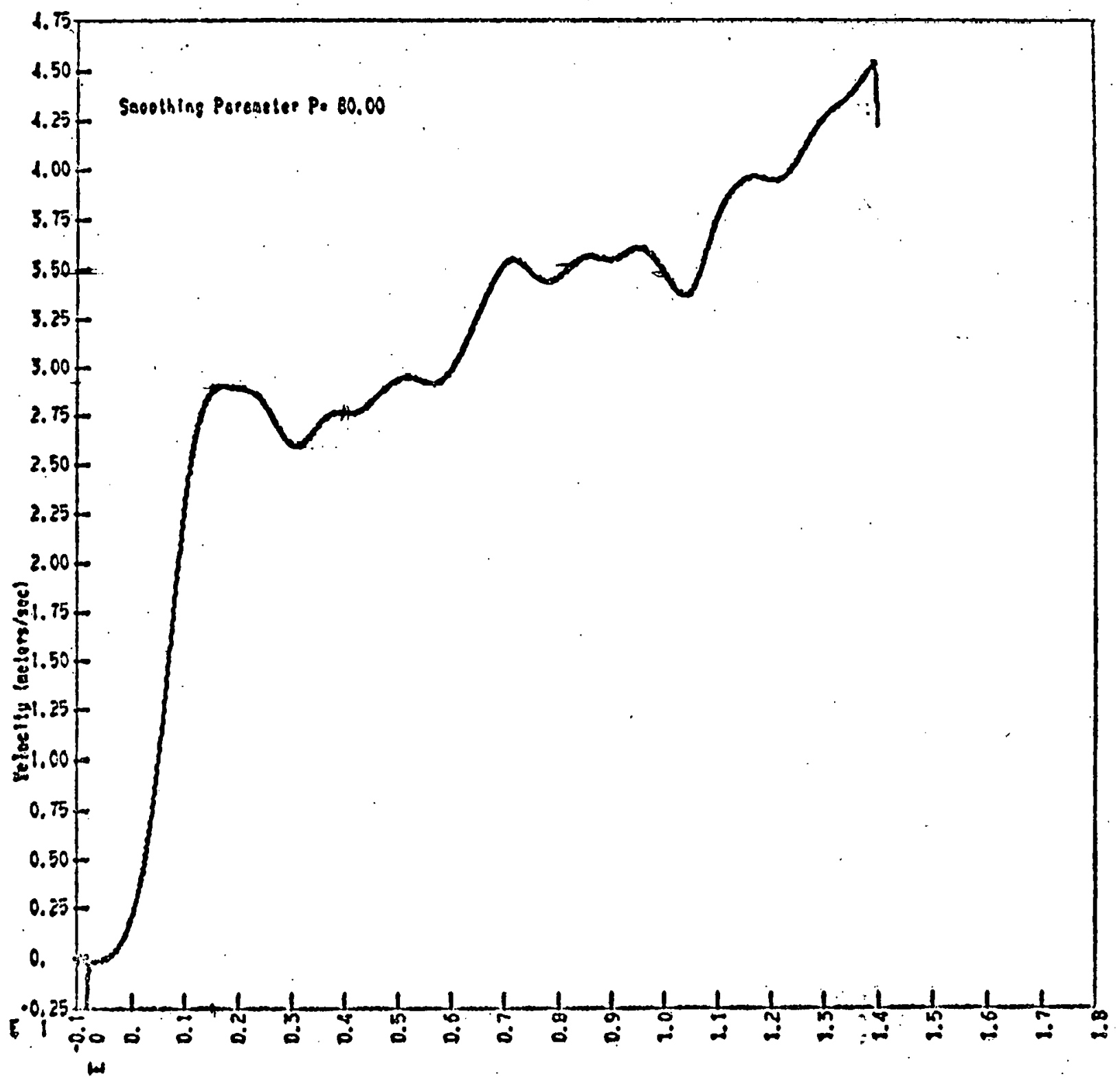

Plee lises.)

FIGURE A-87

Verifical Veleclity Target 8 


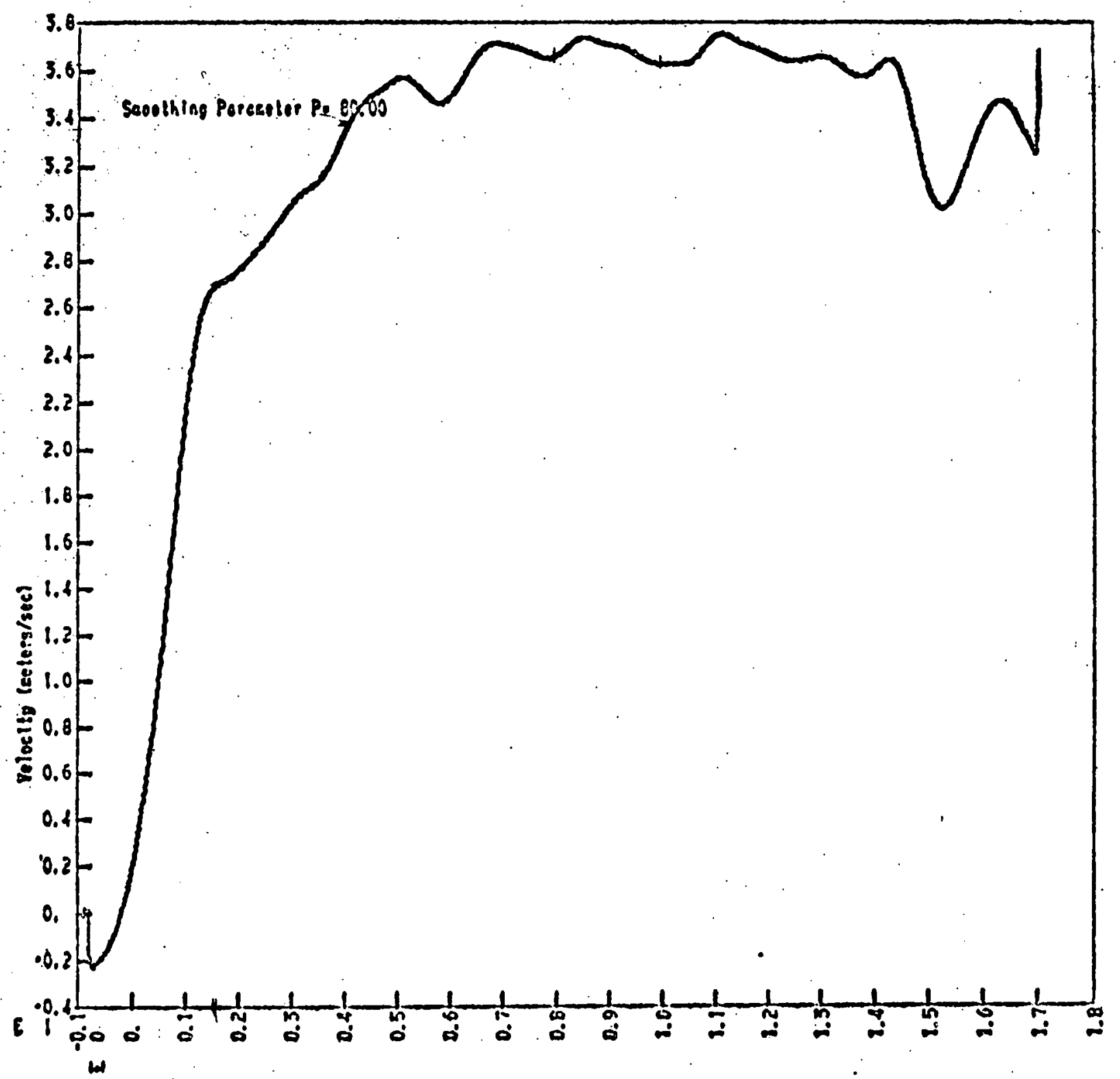

Pisi lses.)

FIGURE A-88

Vertical Velocity Torget 9

$-105-$ 


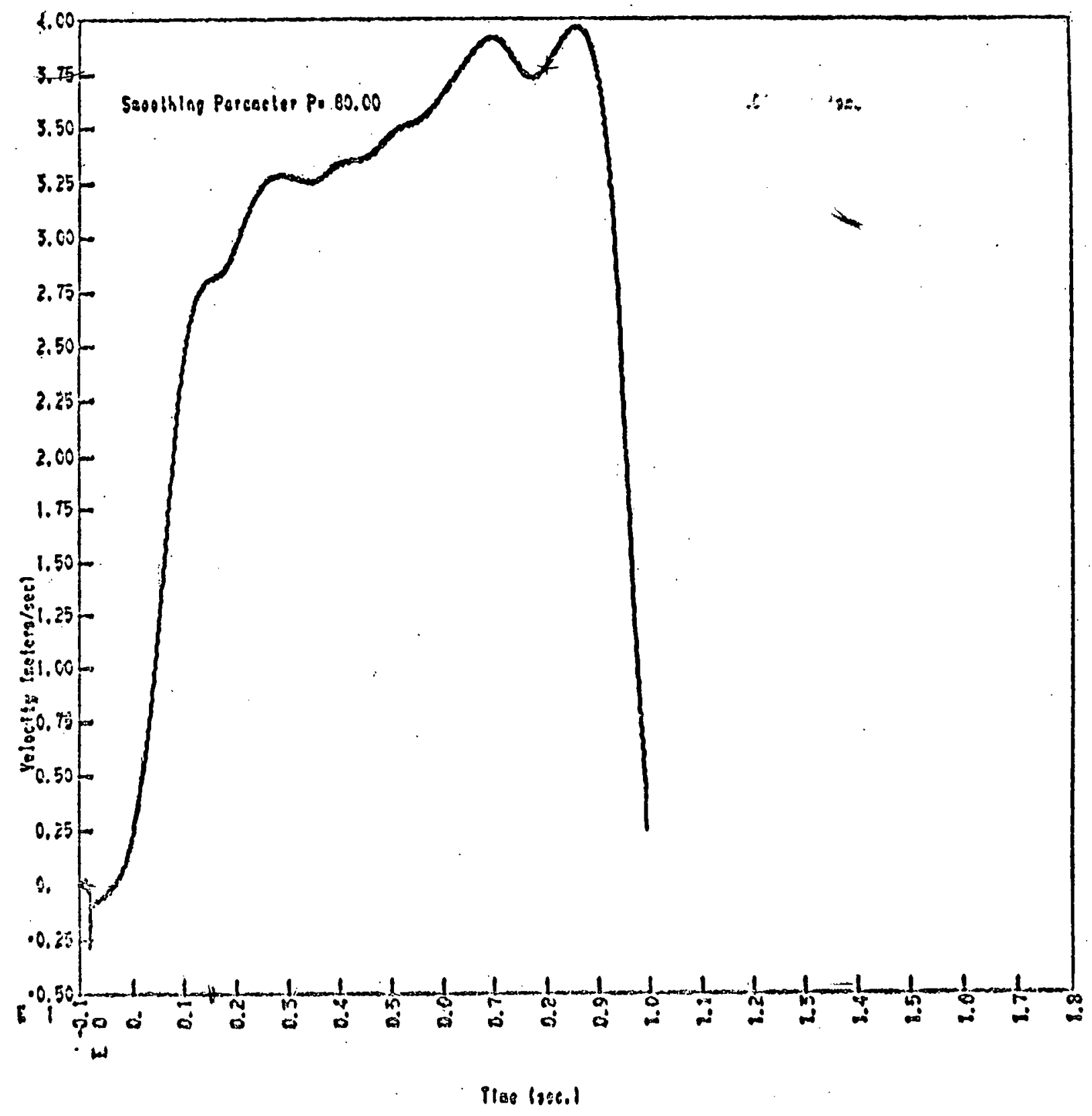

FIGURE A-89

Yortigal Yolocity Target 10 $10 !$ 


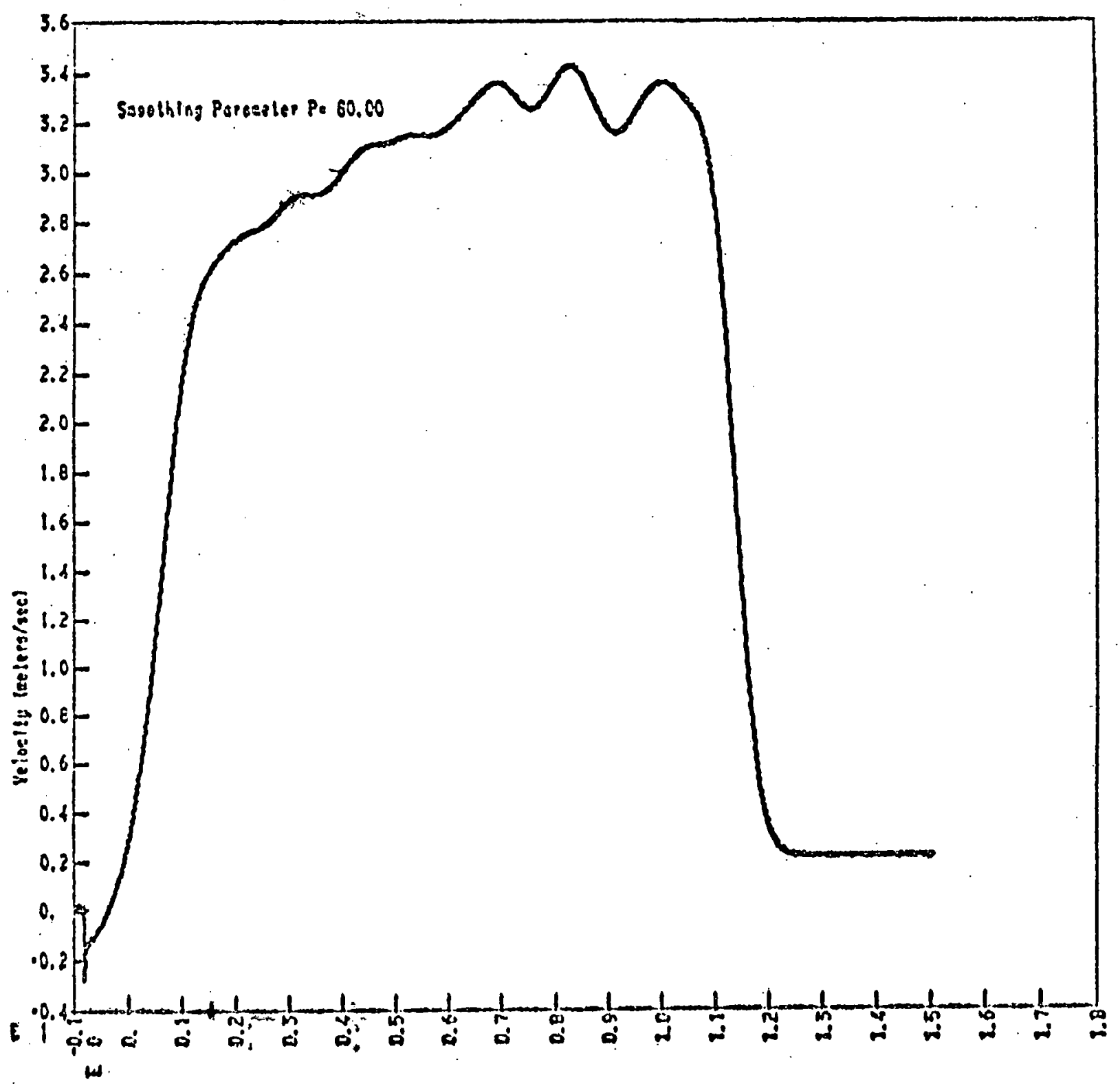

Ples loobil

FICIJRE A-90
Yertlcal Veloclity Toroet 11

$-107-$ 


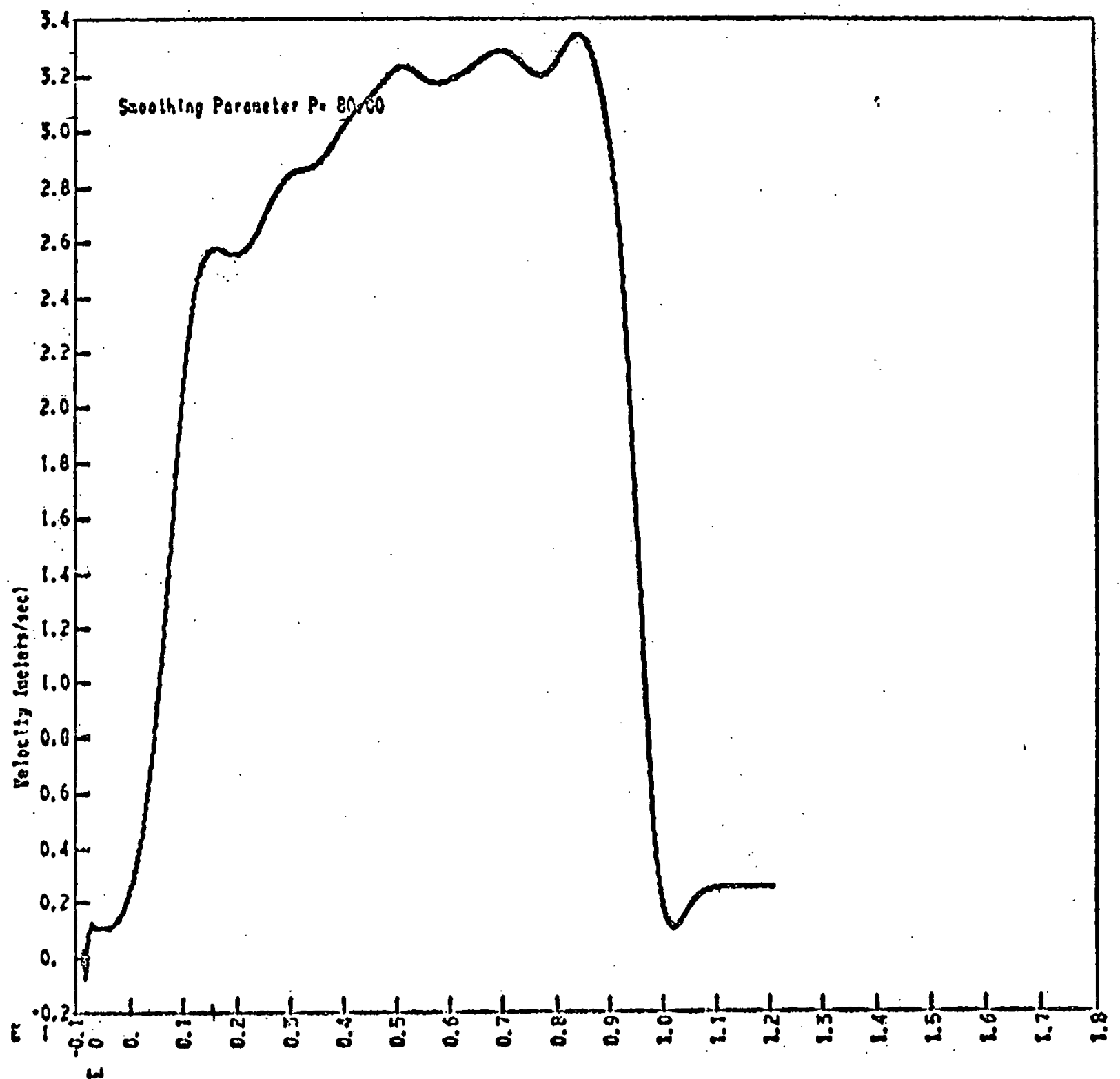

Plese (ses.)

FIGURE A-91

Yerblecl Veloclty Target 12

$-108-$ 


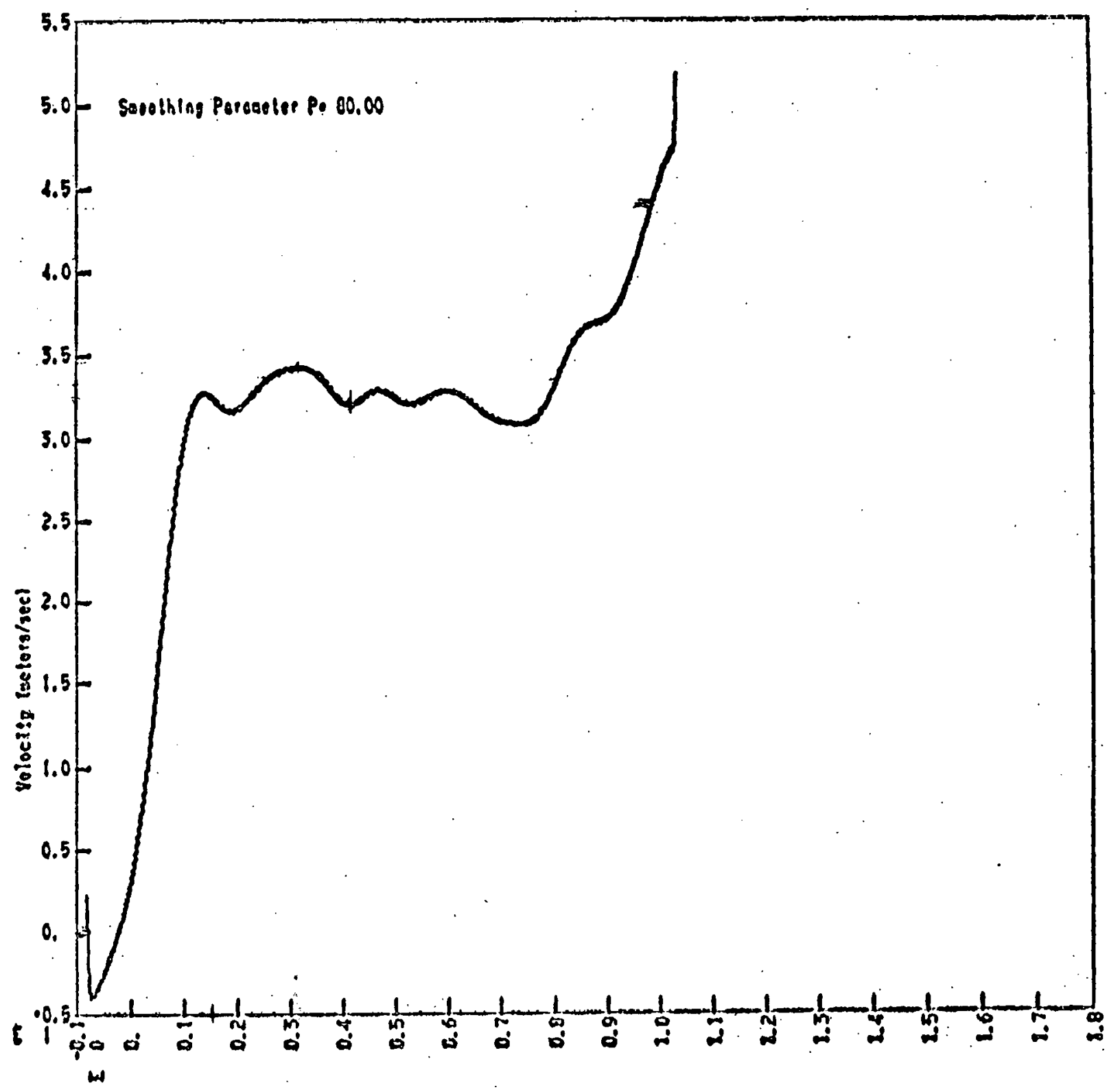

Pieg isce.)

FIGURE A-92

Veplical Yelocily rargot 13 


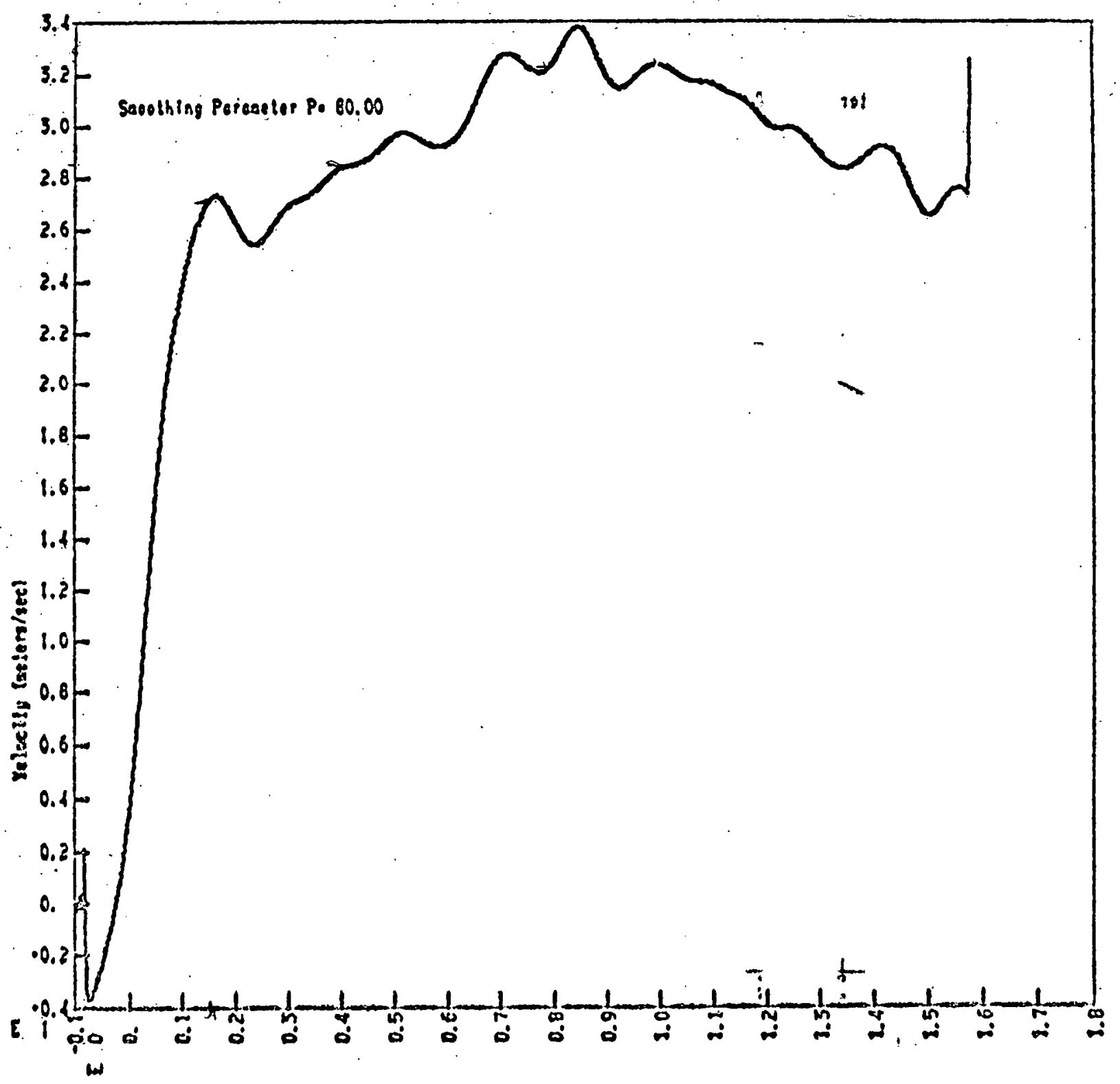

Plap lose.)

FIGURE A-93.

$1 \gamma$

$\$ 7$

Yertical Yelocity Target la

$-110-$ 


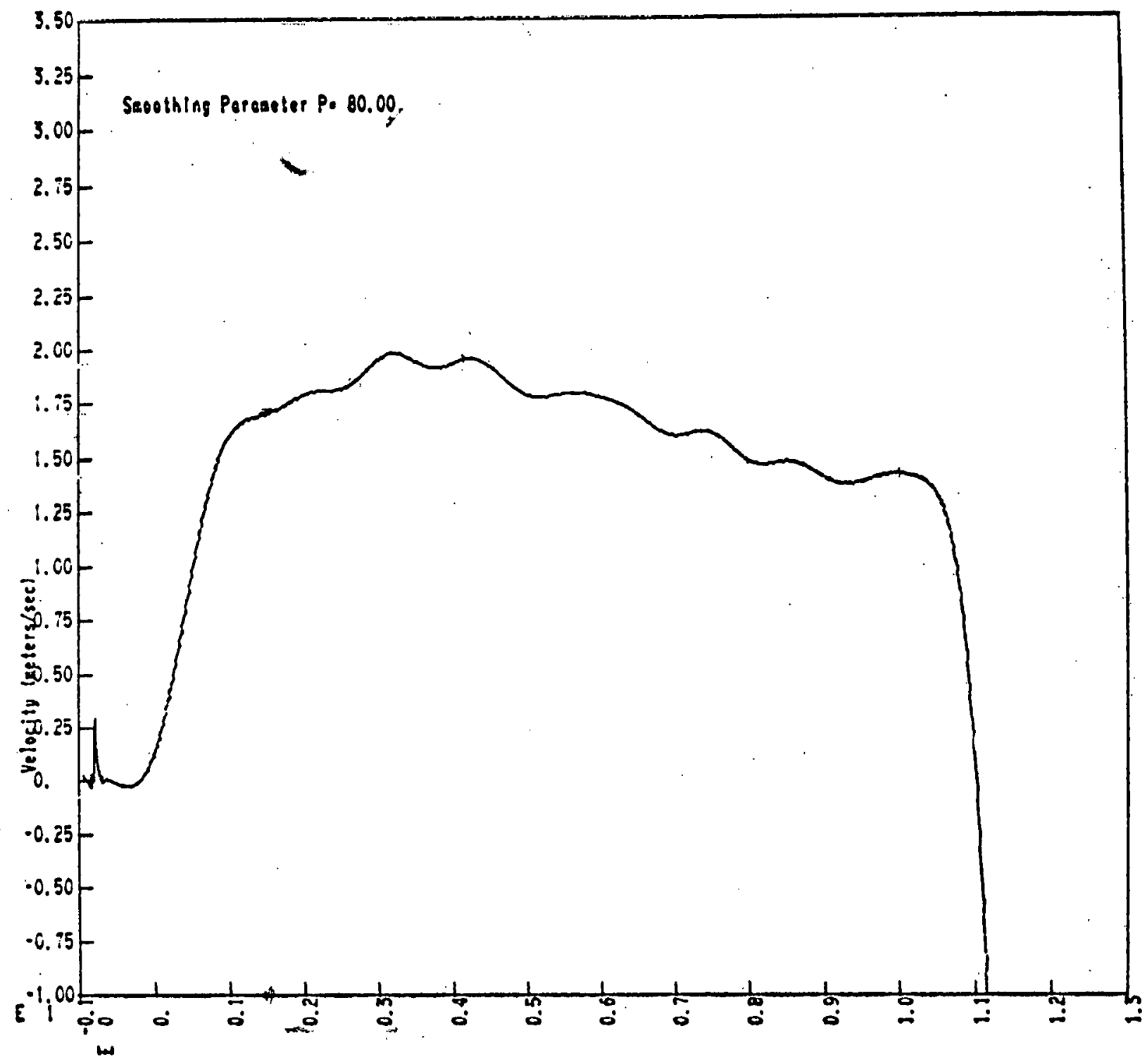

Ilae (ses.)

FIGURE A-94

Yertical Yelocity Torget 15

$-111-$ 


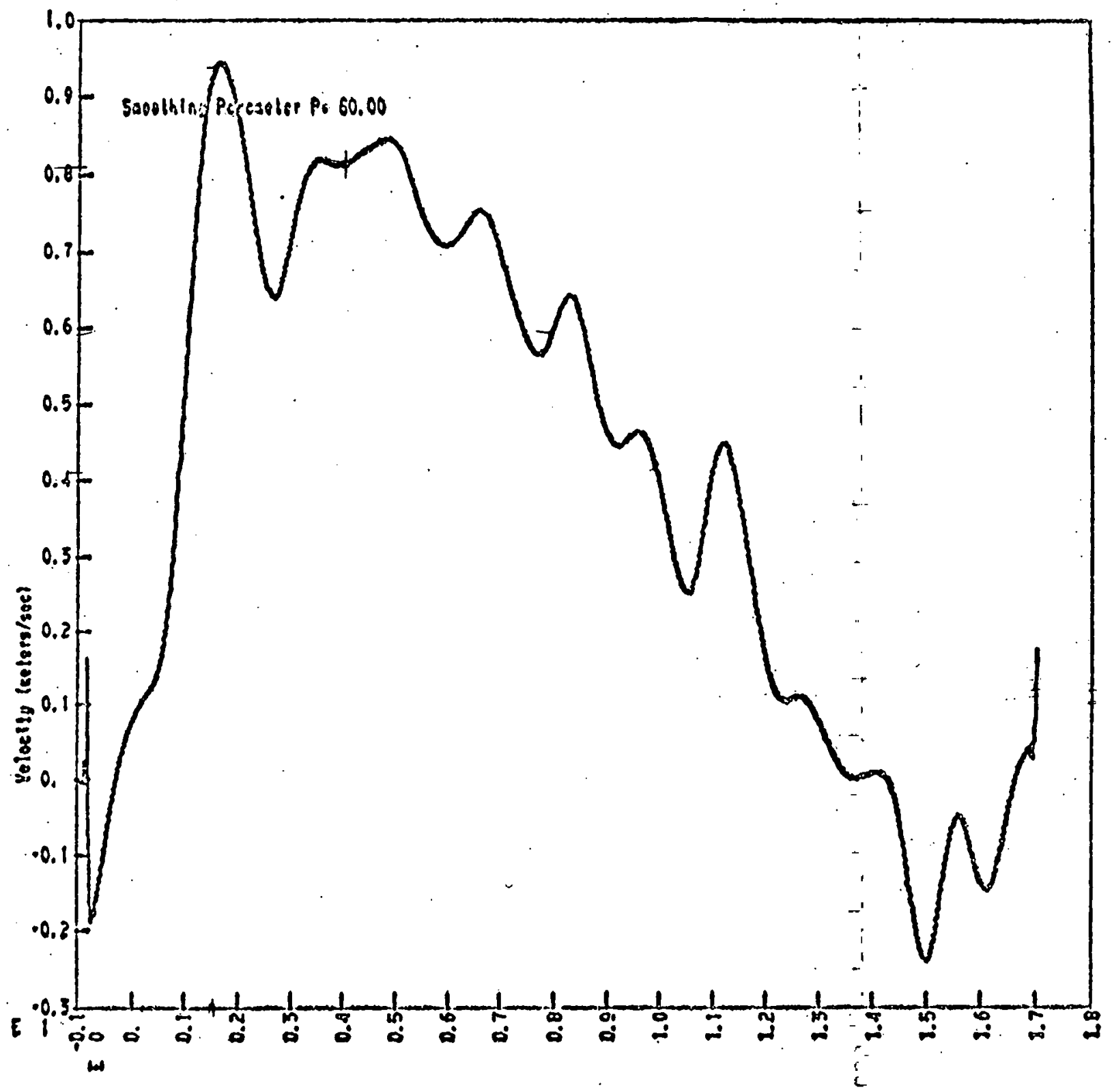

fies loec.)

FIGURE A-95

Yeptical Veloclty Target 16

:-112- 


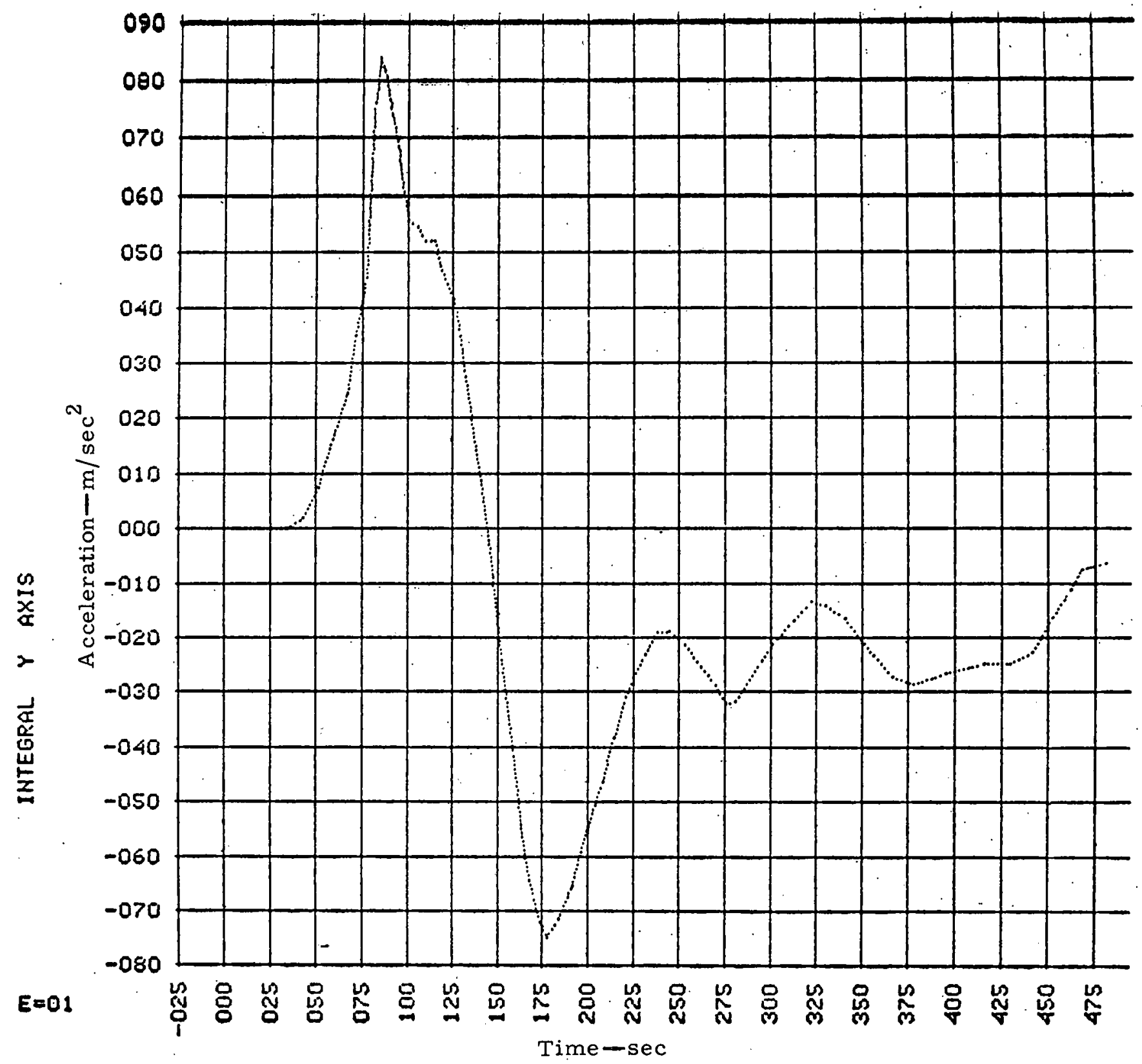

品

INTEGRAL $X$ AXIS

BUGGY A 1 ACCEL.

Fig. A-96 


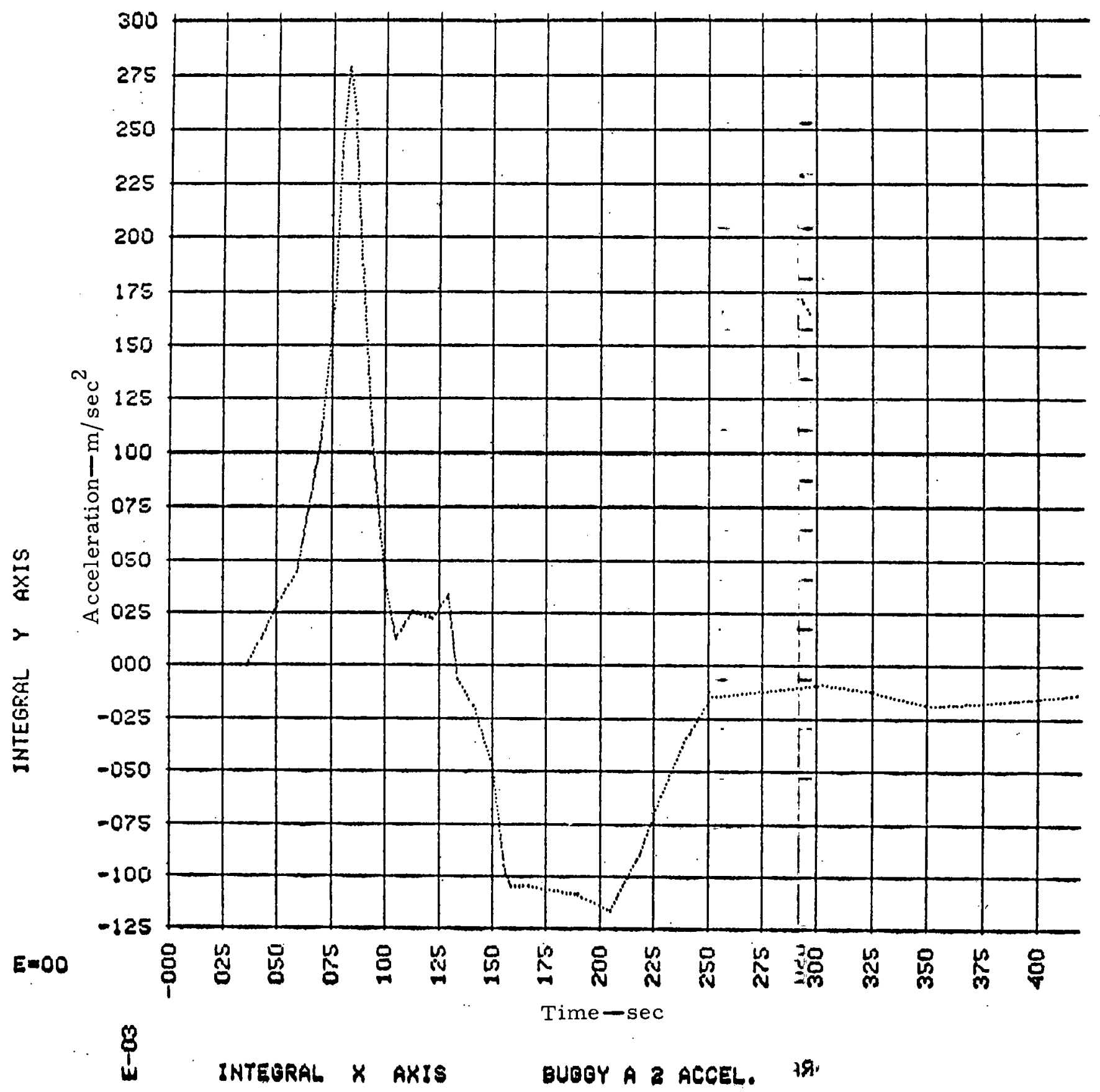

Fig. A-97 


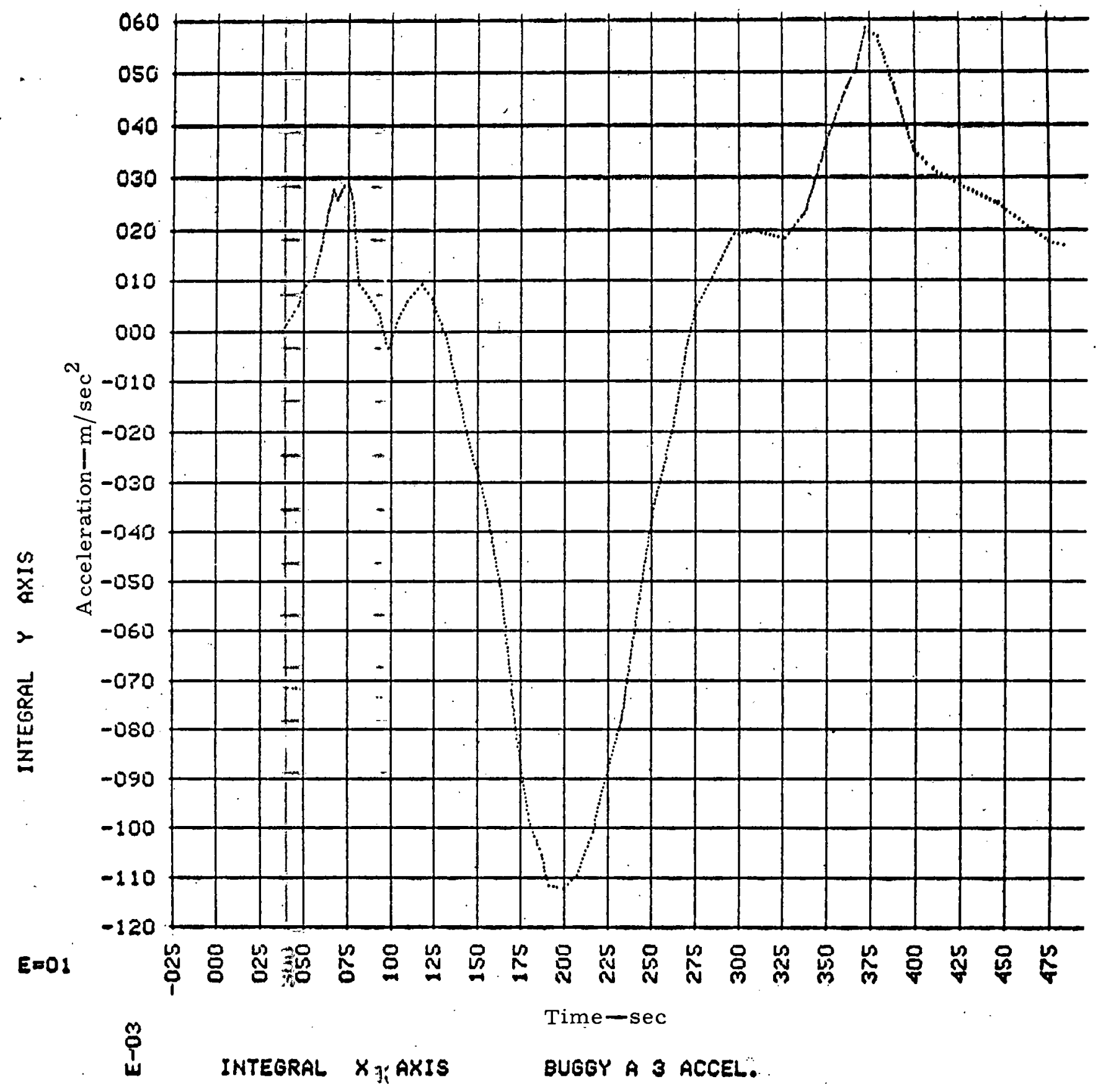

Fig. A-98 


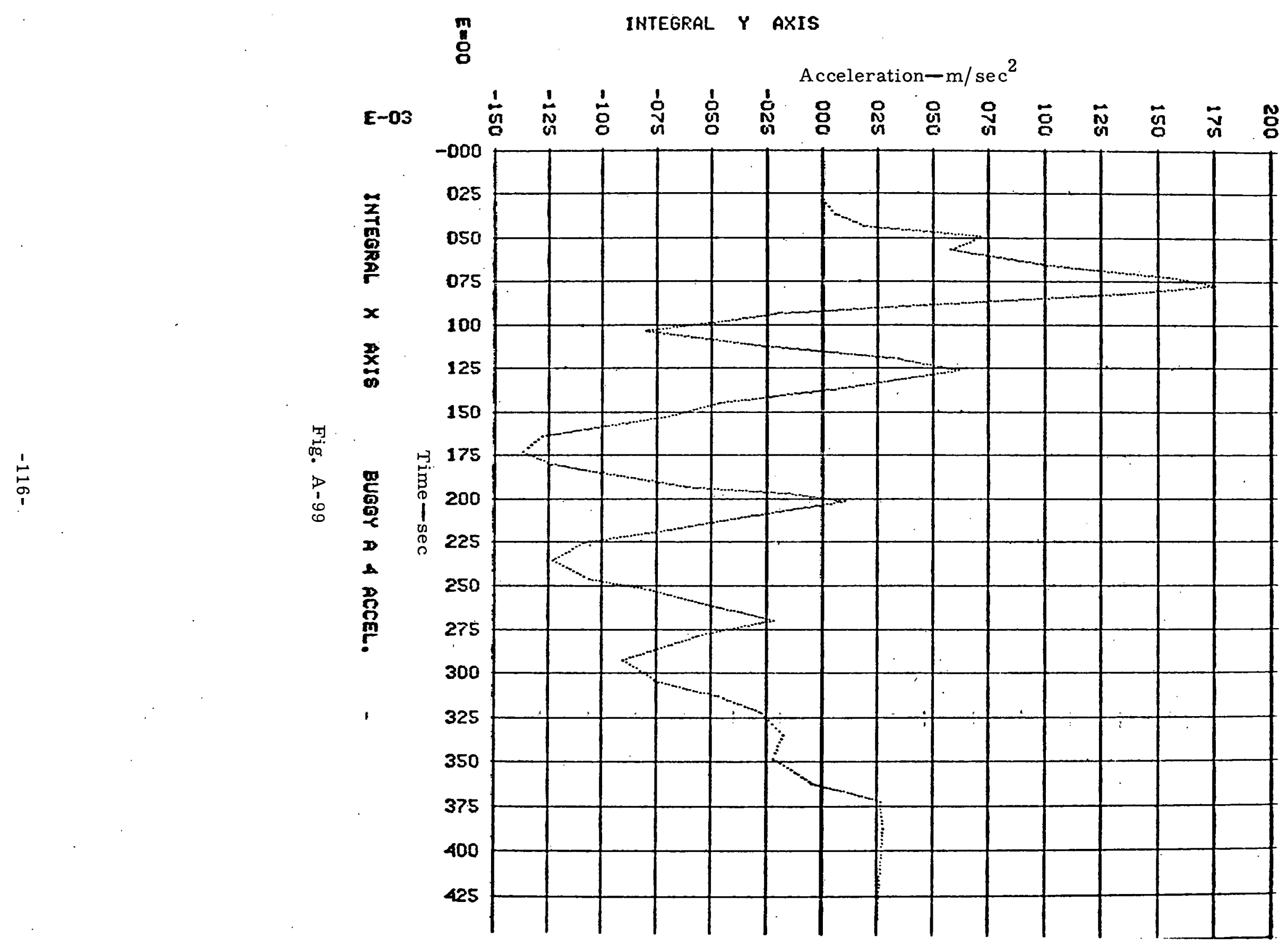




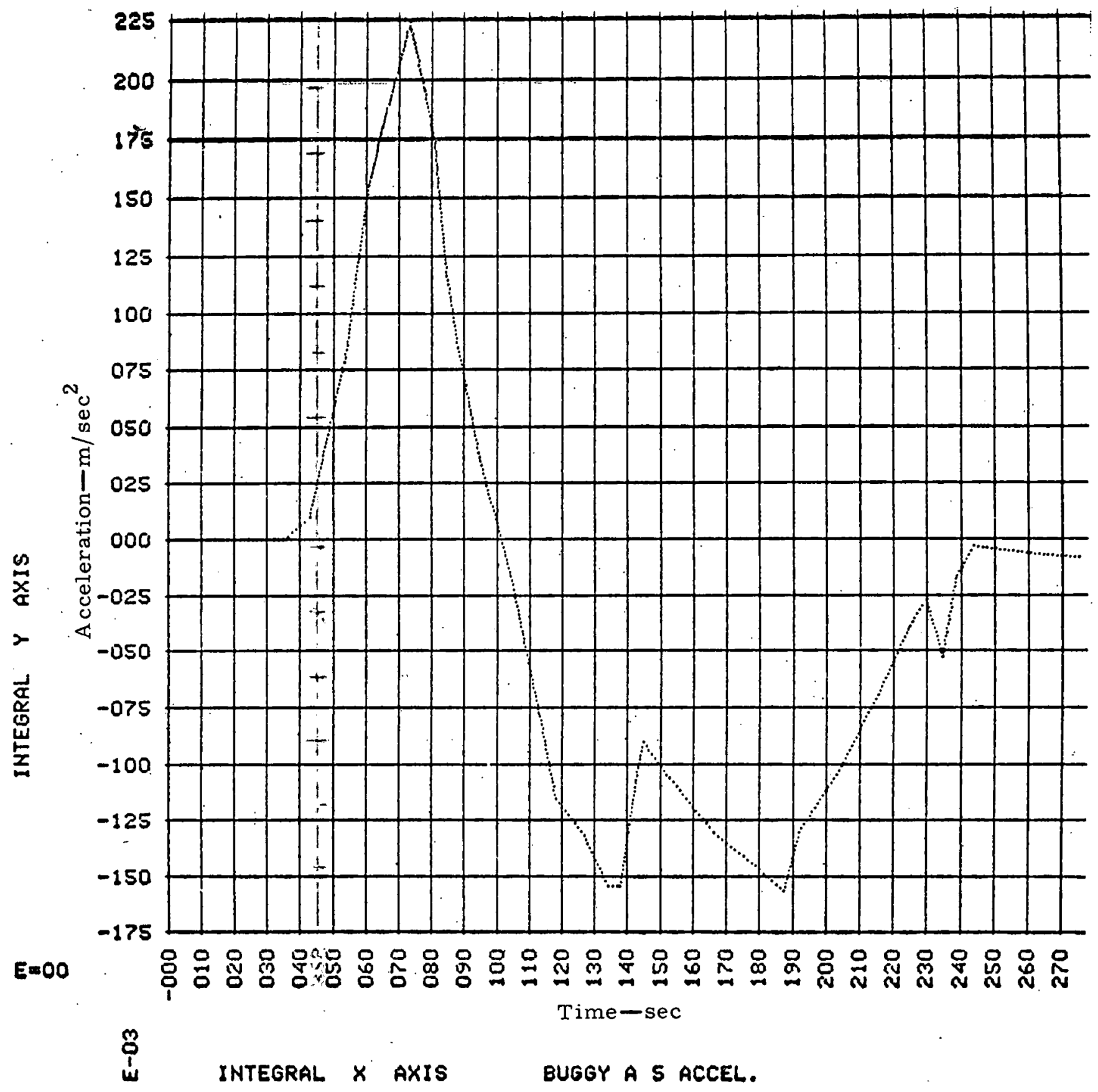

Fig. $A-100$ 


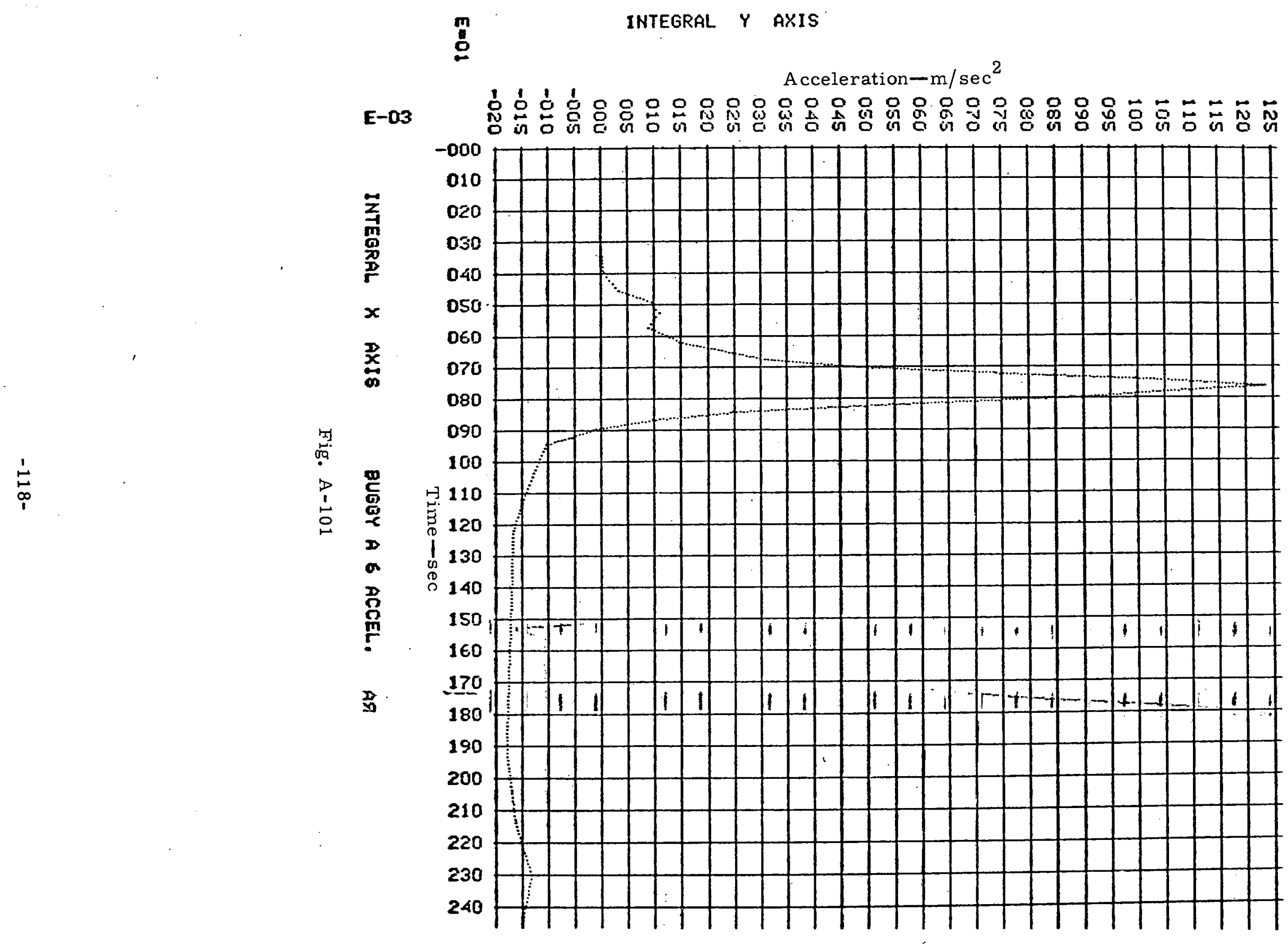




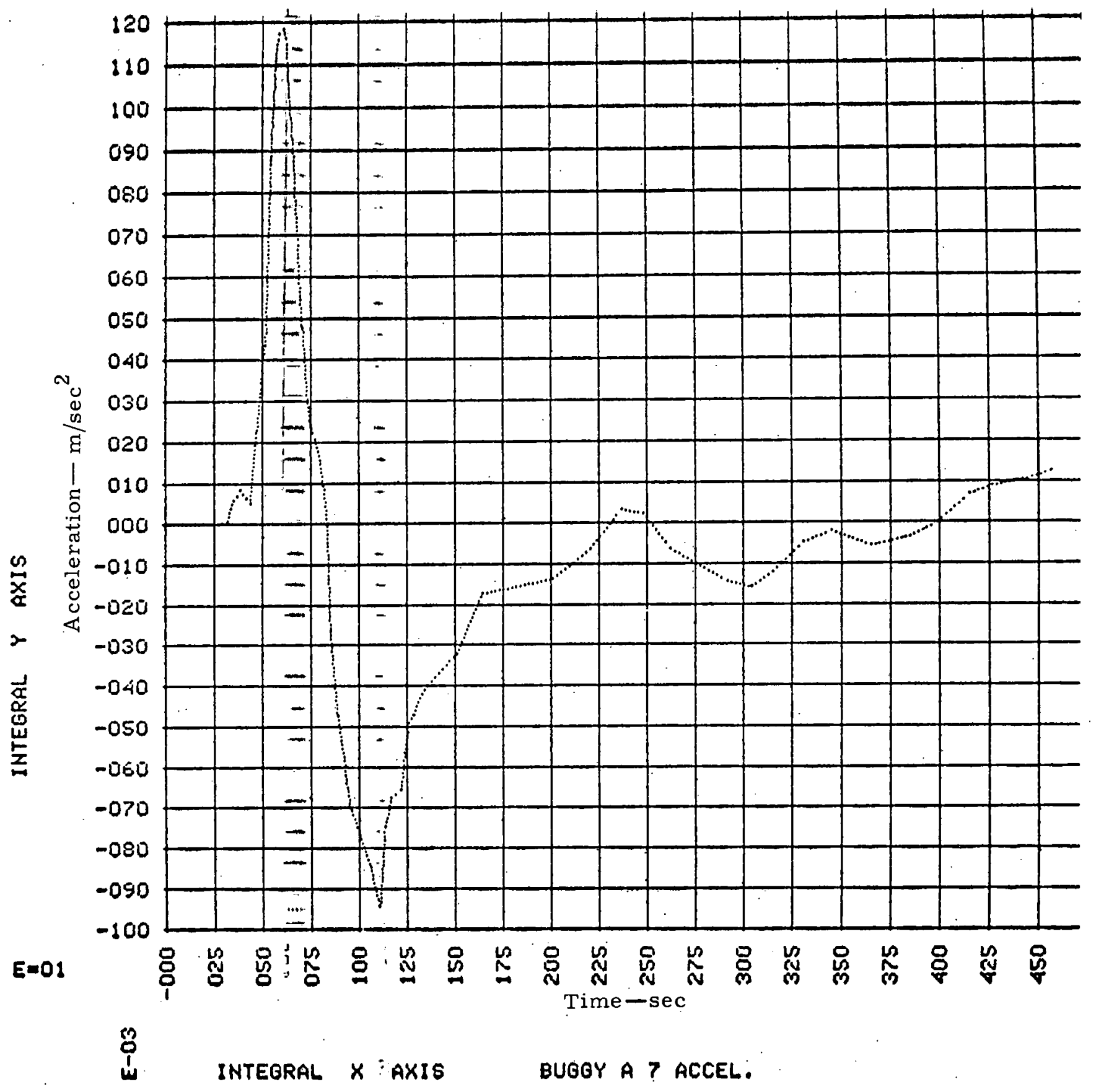

Fig. A-102 


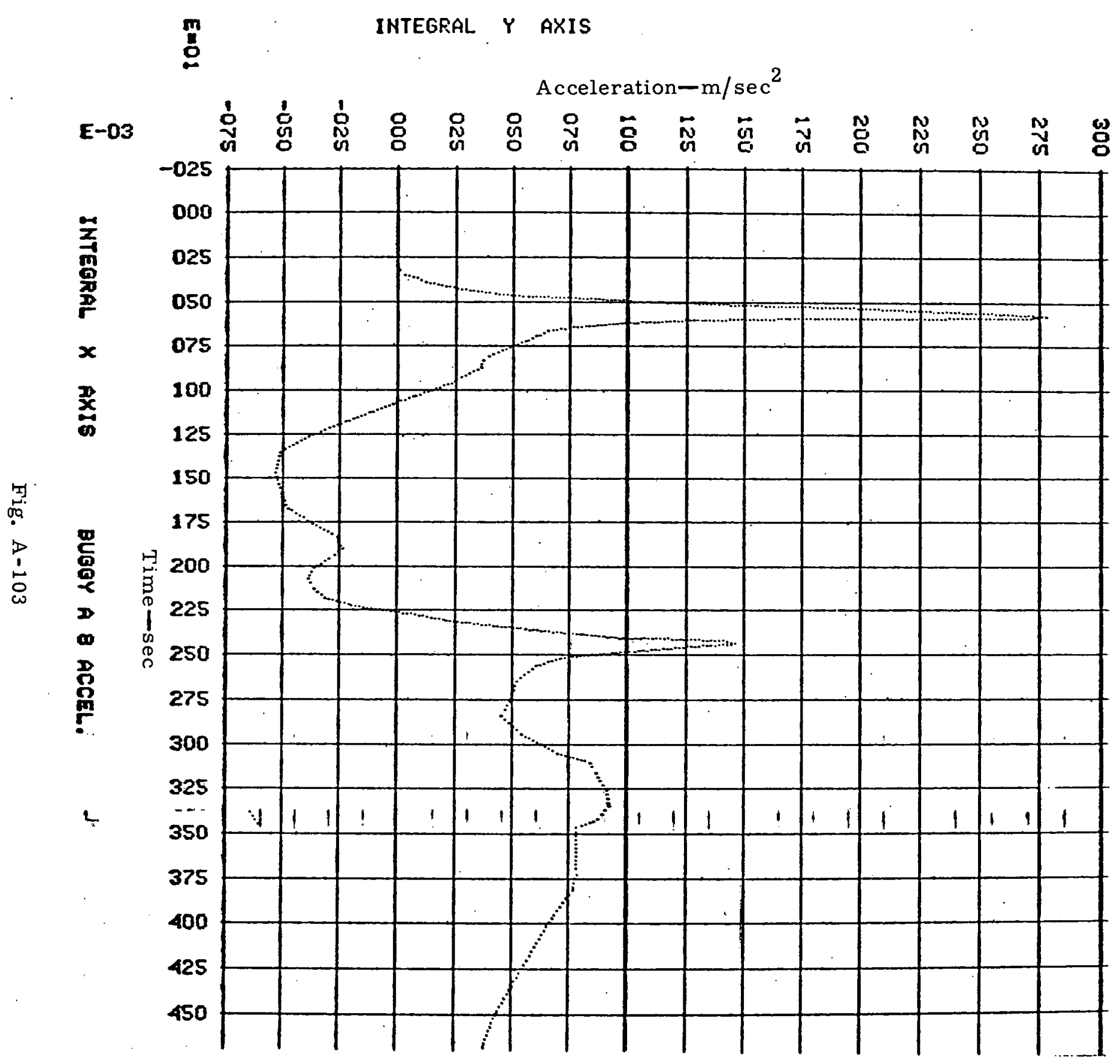




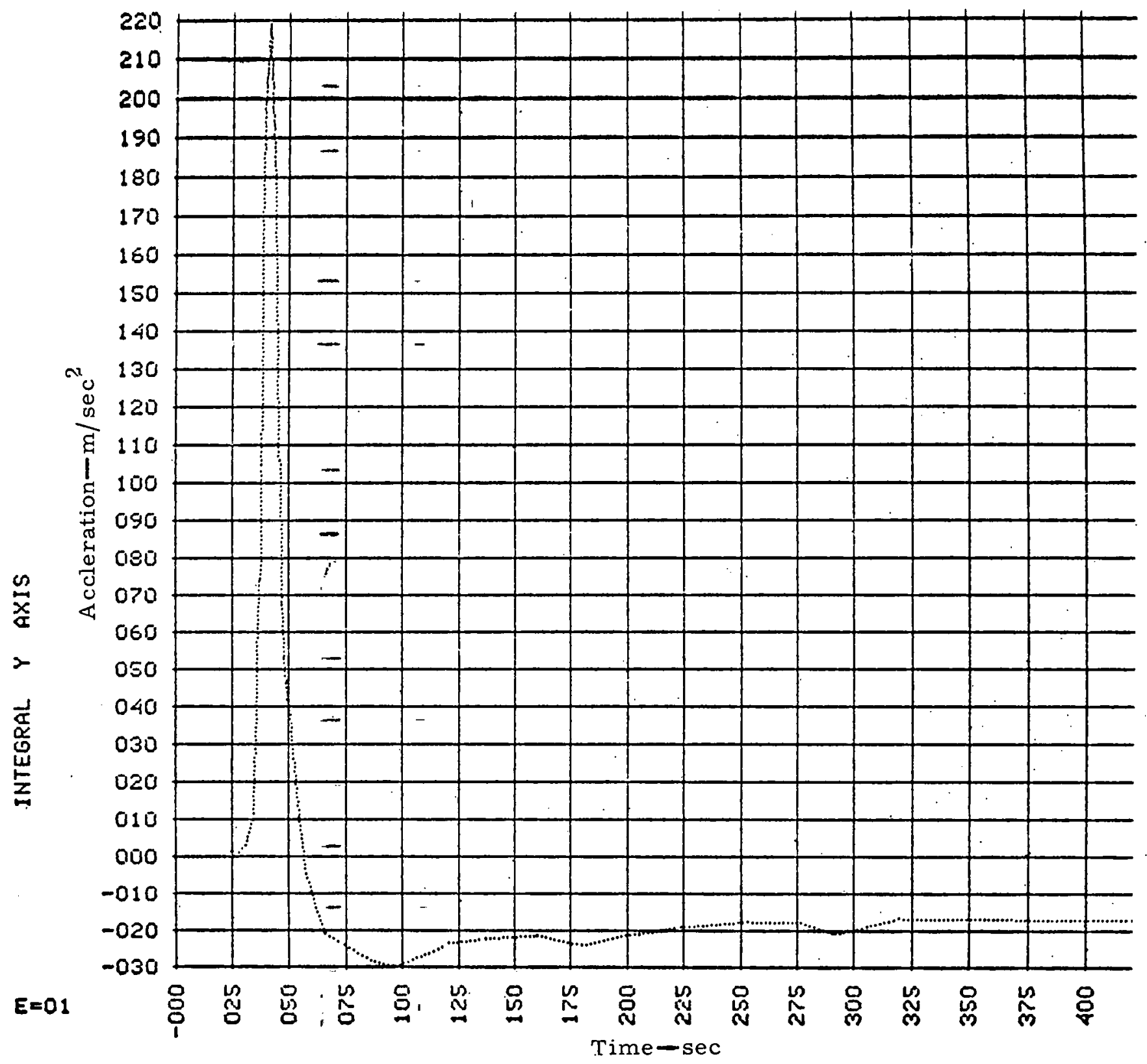

$n$
1

INTEGRAL $\times$ AXIS

BUGGY A 9 ACCEL.

Fig. A-104 


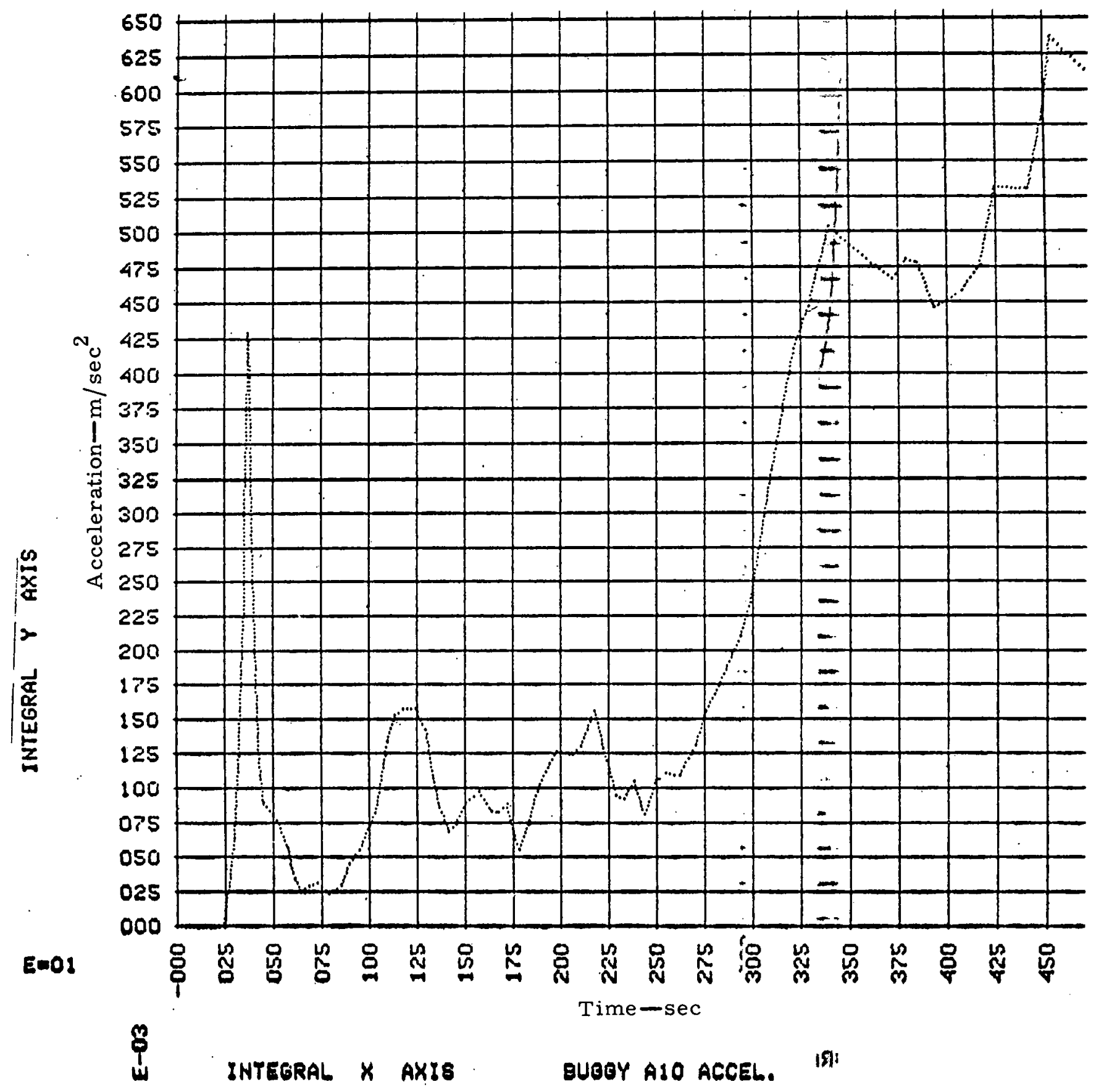

Fig. A-105 


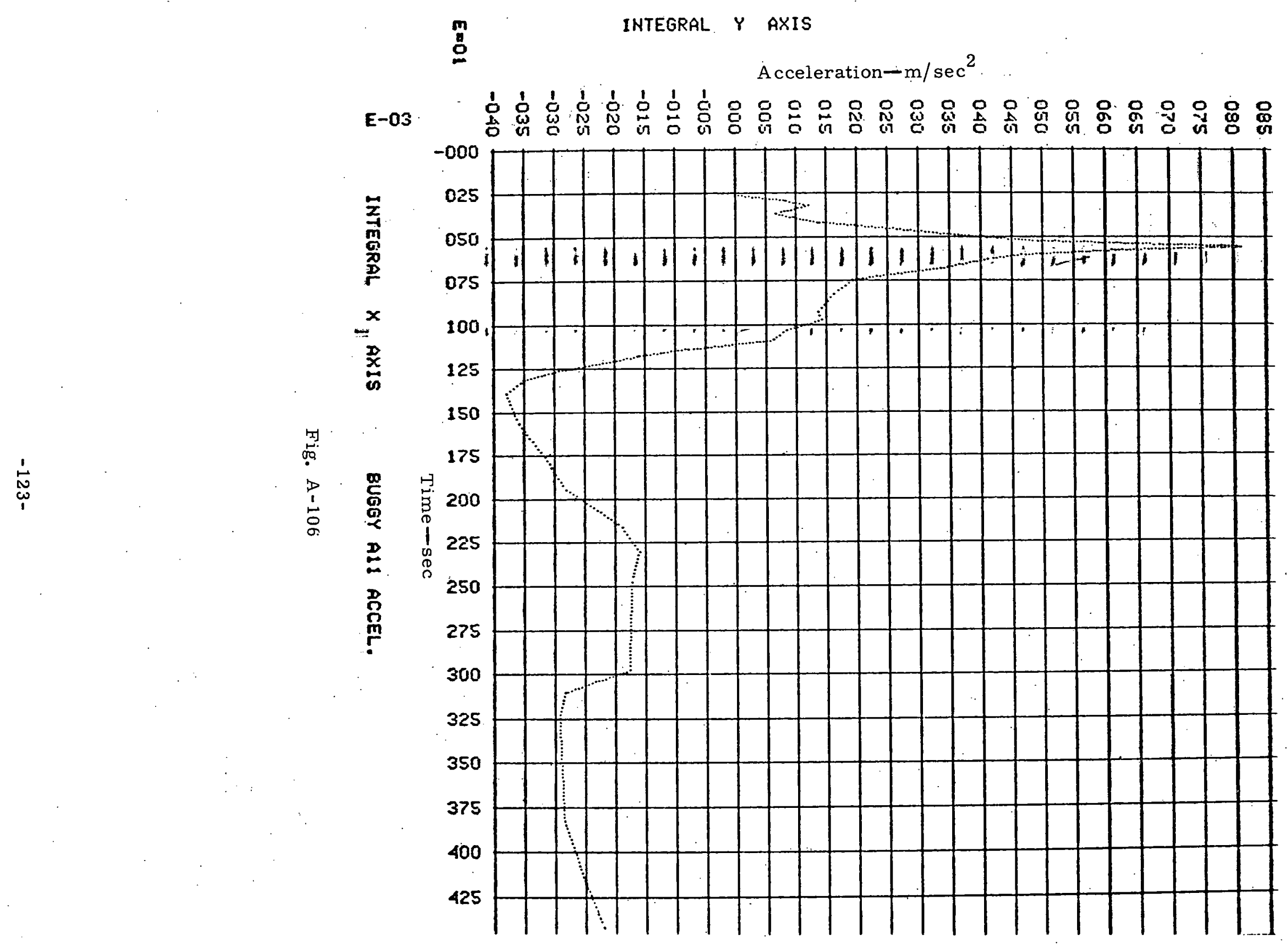




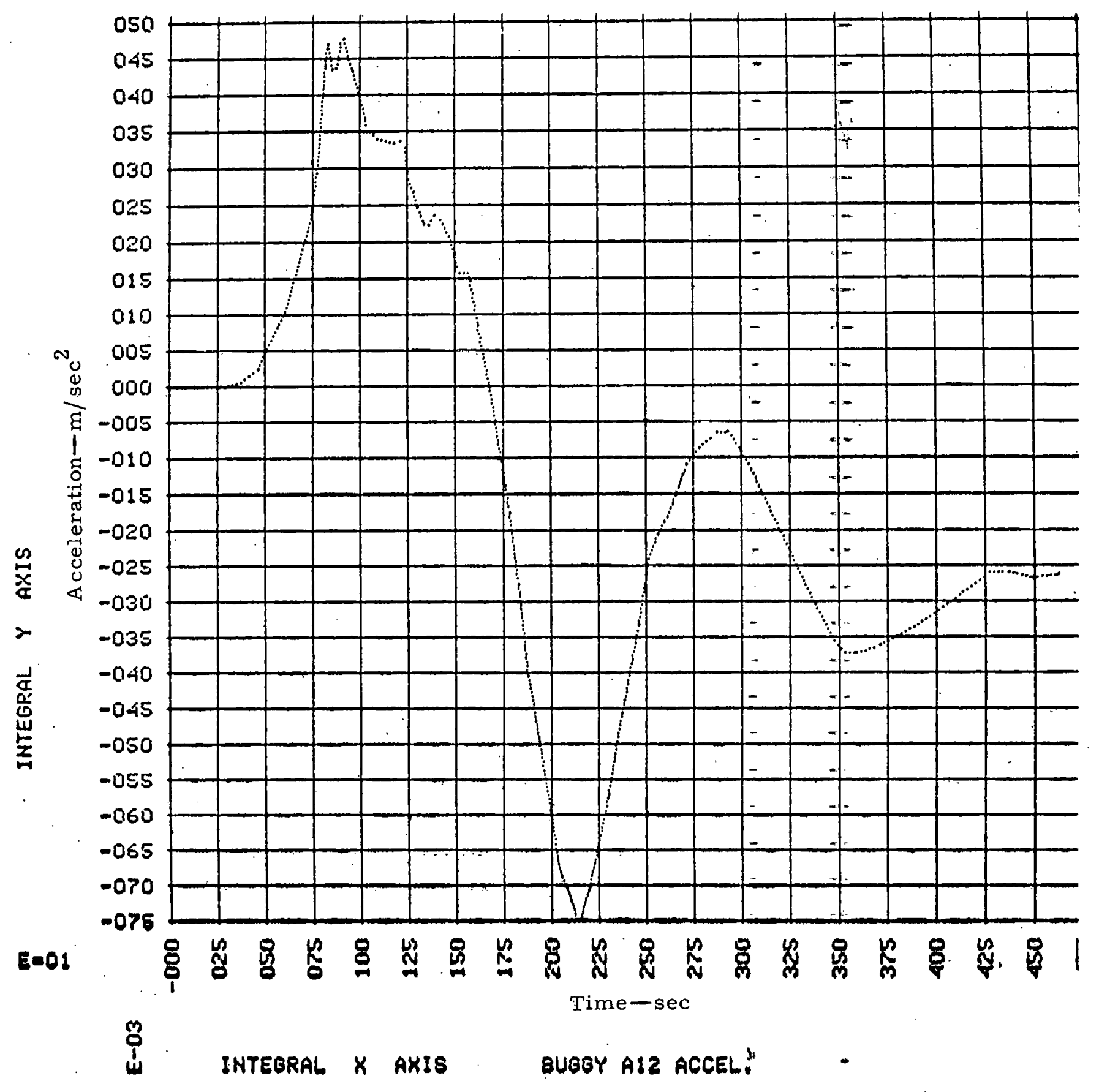

Fig. A-107 


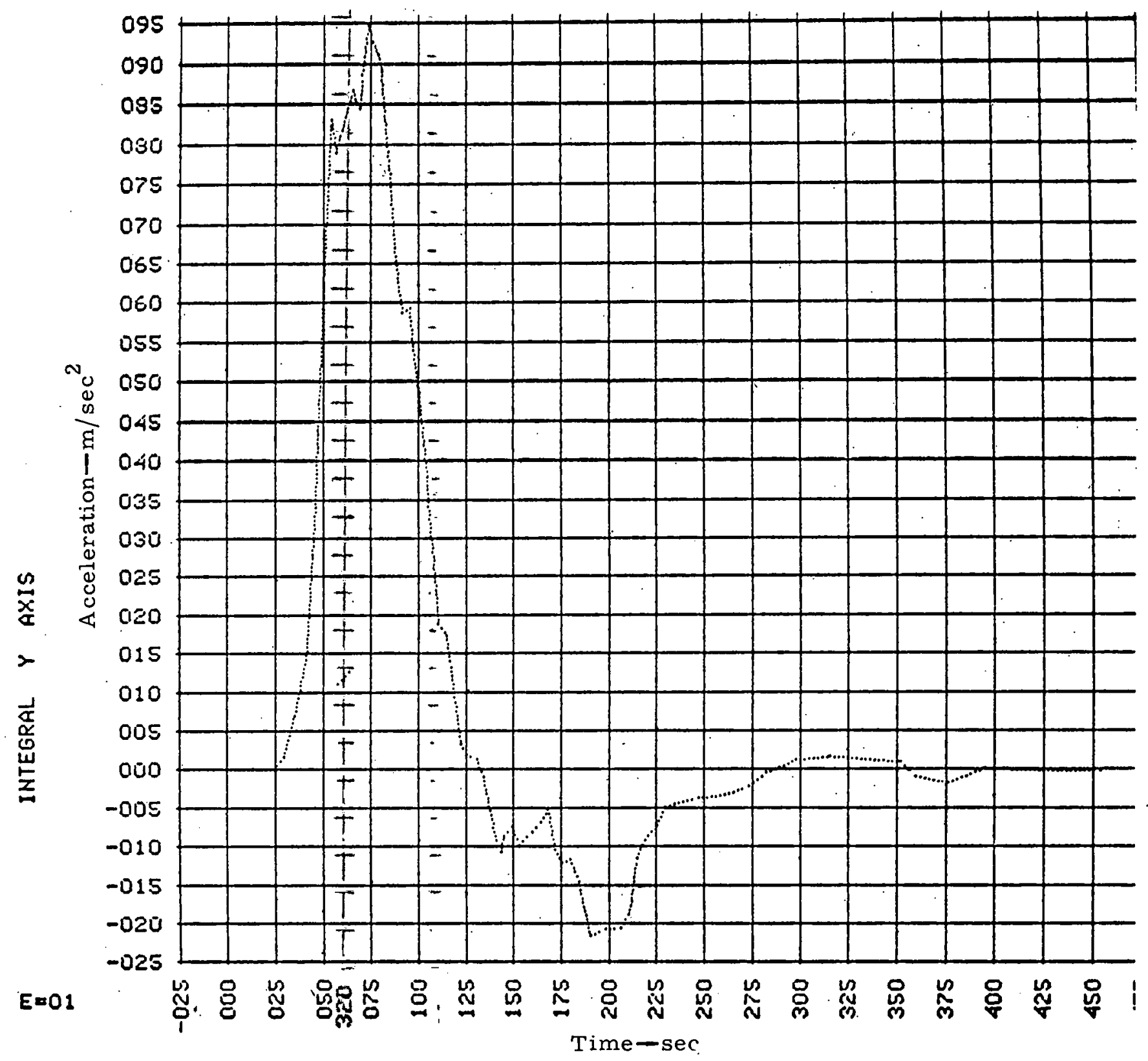

菖

INTEGRAL $X$ AXIS

BUGGY A13 ACCEL.

Fig. A-108 


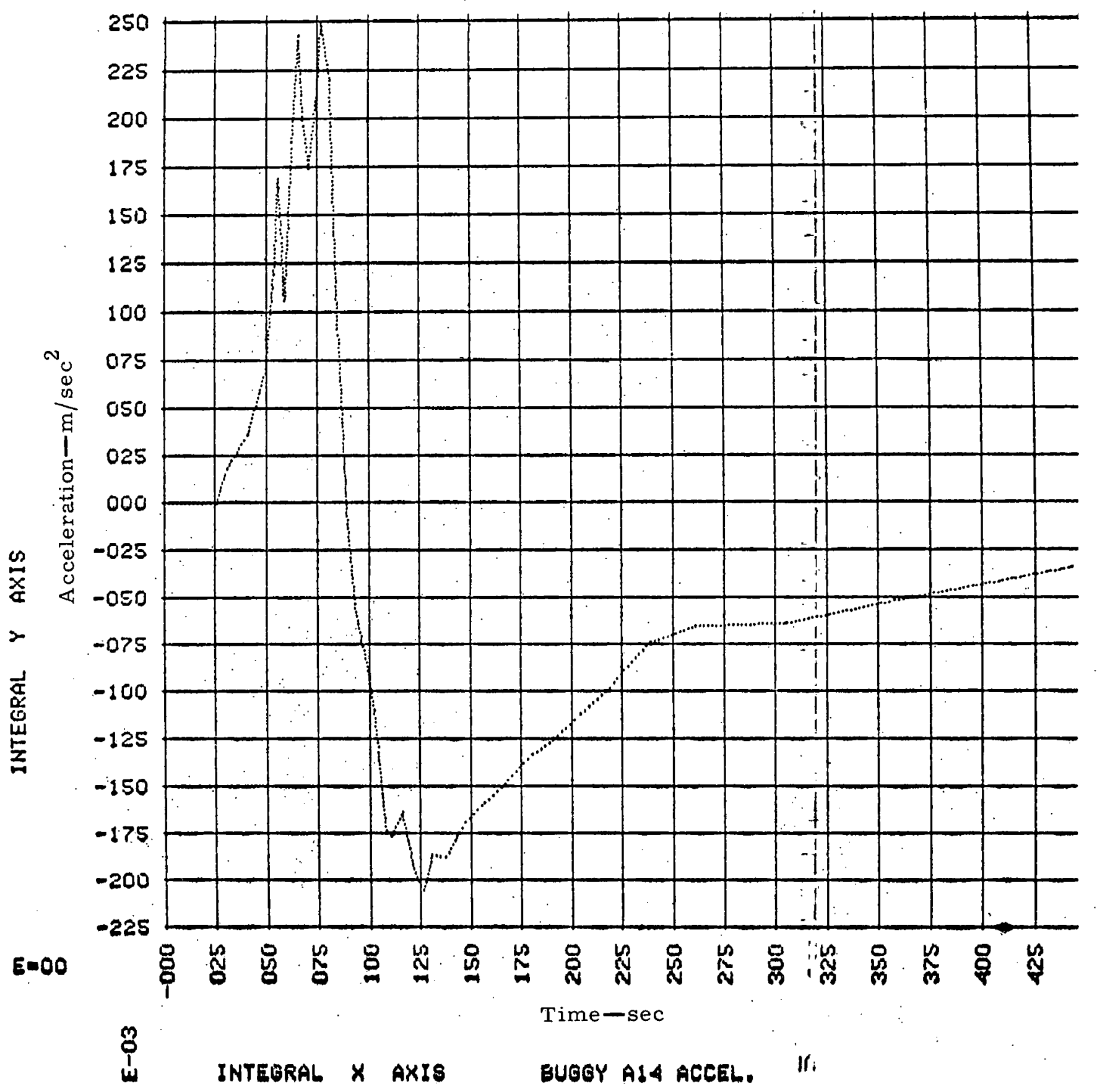

Fig. A-109 


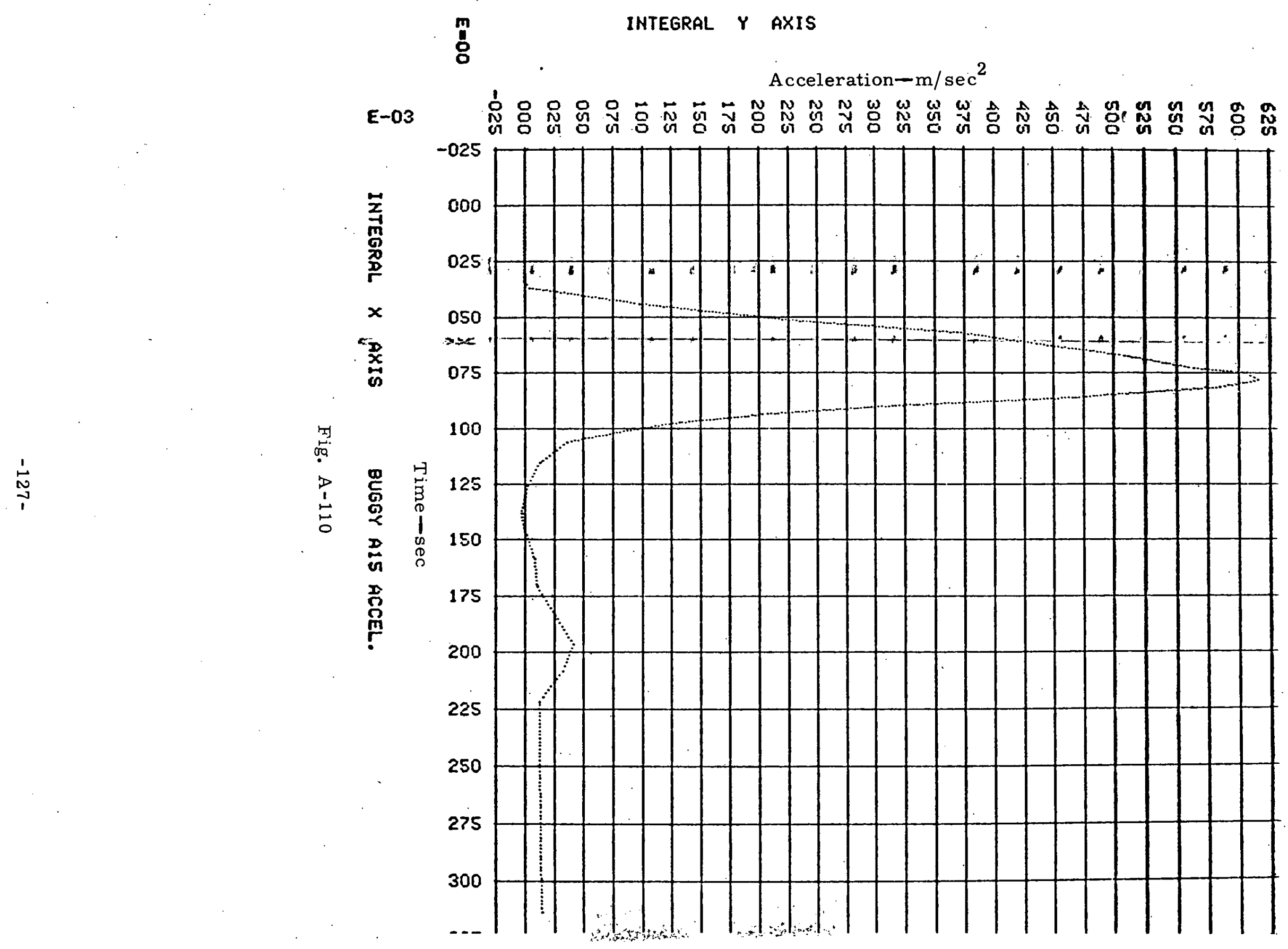




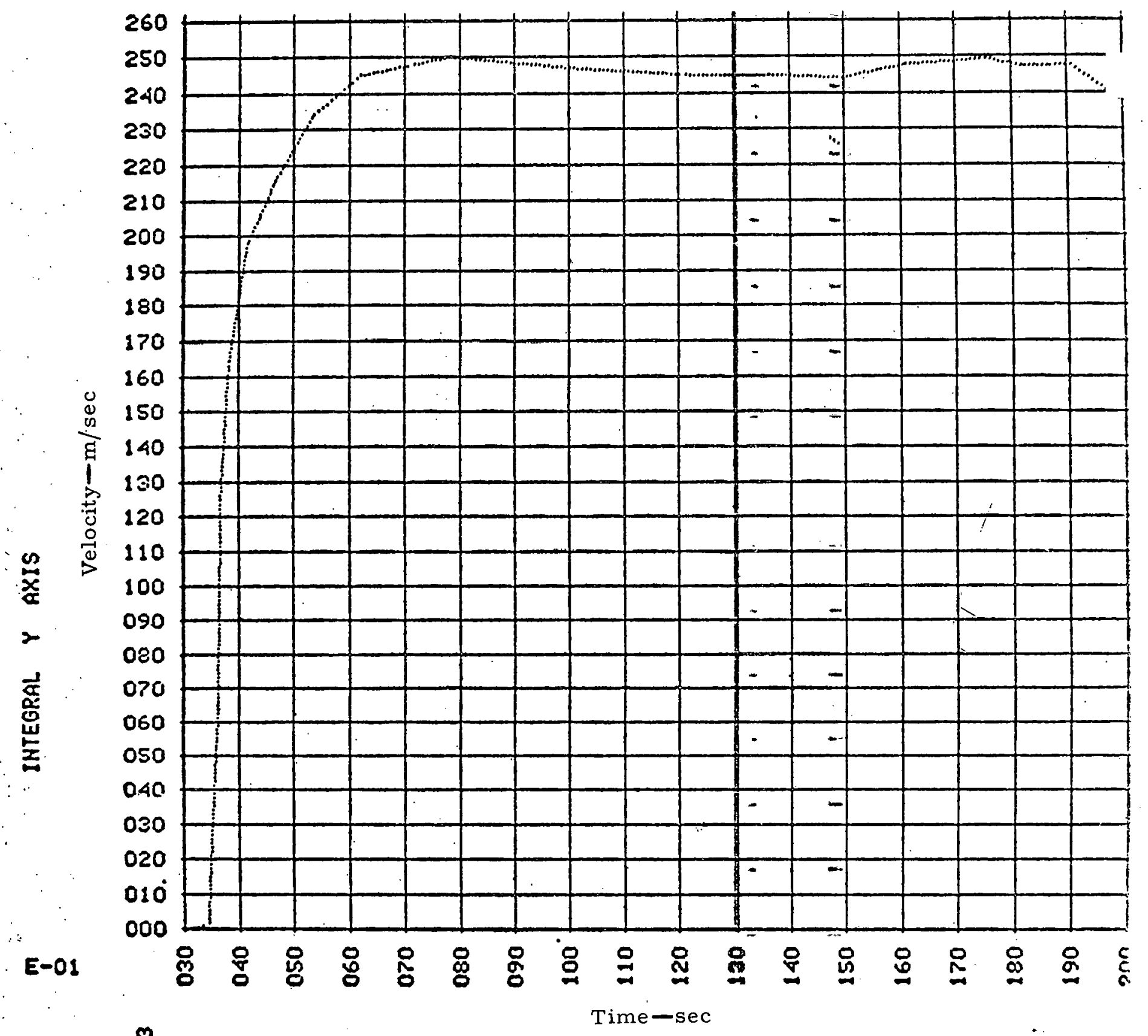

8
1
1 INTEGRAL $\times$ AXIS

V4 WITH $2 \times$ VA CALIBRATIÓN AT CHÁRGE A Fig. A-111 


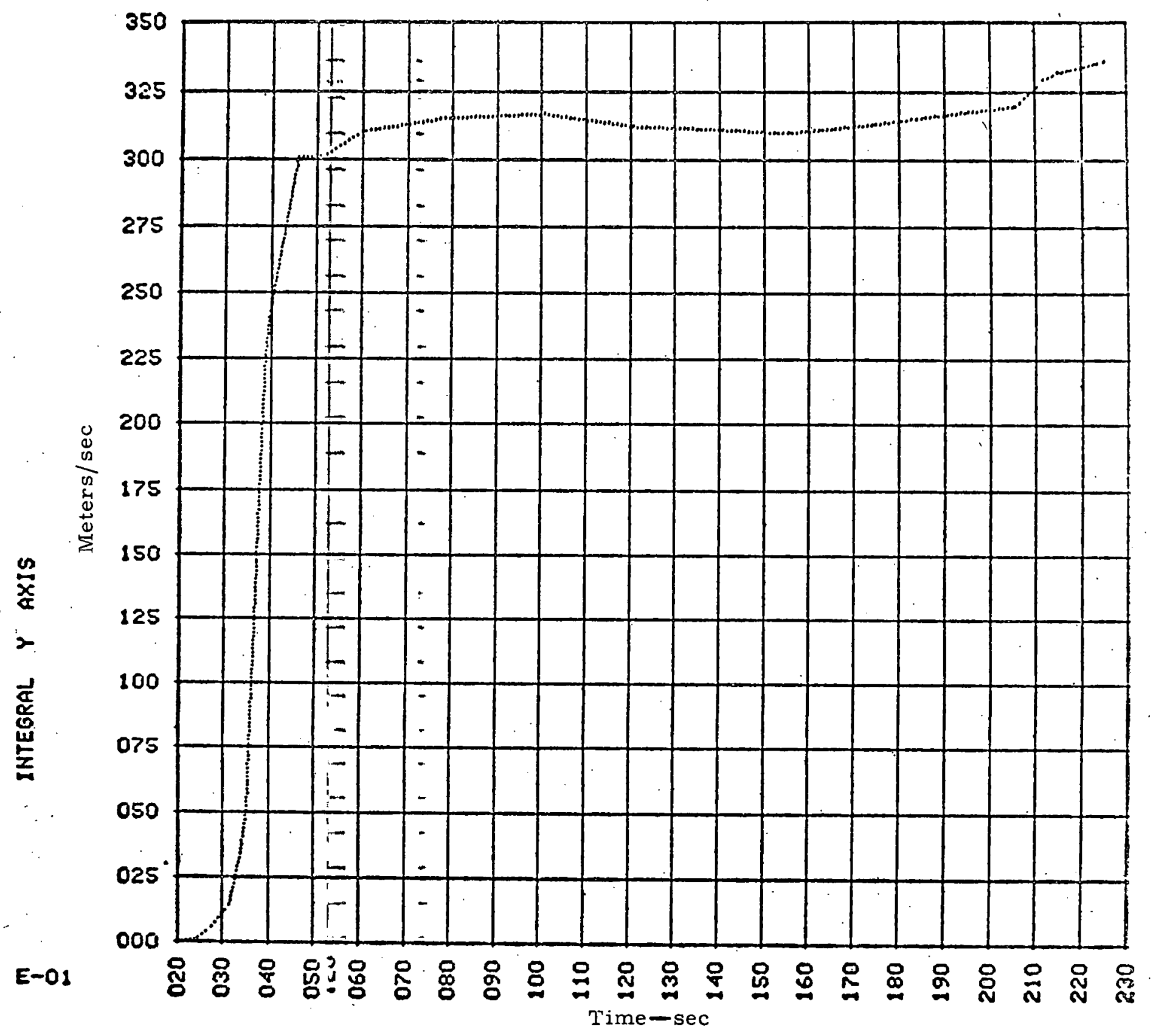

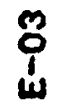

INTEGRALL $X$ AXIS

V2 WITH 2NC CALIBRATION AT CHARGE C

Fig. $A-112$ 
PROJECT BUGGY REPORTS

\begin{tabular}{|c|c|c|c|}
\hline Report & Agency & Author & Title \\
\hline PNE-322 & WES & $\begin{array}{l}\text { R. J. Lutton } \\
\text { R. W. Hunt. } \\
\text { R. E. Rowland }\end{array}$ & $\begin{array}{l}\text { Preshot Geologic and } \\
\text { Engineering Properties } \\
\text { Investigation }\end{array}$ \\
\hline PNE- 325 & LRL & $\begin{array}{l}\text { R. F. Rohrer } \\
\text { W. R. Hurdlow }\end{array}$ & $\begin{array}{l}\text { Photographic and Acceler- } \\
\text { ometer Measurements of } \\
\text { the Surface Motion on the } \\
\text { Buggy Cratering Experiment }\end{array}$ \\
\hline PNE- 326 & ERC & $\begin{array}{l}\text { C. R. Cassity } \\
\text { R. W. Klepinger } \\
\text { J. A. Lahoud } \\
\text { J. R. Murphy }\end{array}$ & Analysis of Ground Motion \\
\hline & USPHS & & $\begin{array}{l}\text { Off-Site Radiological } \\
\text { Surveillance }\end{array}$ \\
\hline & ARL & & $\begin{array}{l}\text { Weather and Radiation } \\
\text { Predictions }\end{array}$ \\
\hline & REECo & & $\begin{array}{l}\text { On-Site Radiological } \\
\text { Safety }\end{array}$ \\
\hline
\end{tabular}


DISTRIBUTION LIST

(TID-4500, Category UC-35)

No. Copies

1 AEC ALBUQUERQUE OPERATIONS OFFICE

1 AEC BETHESDA TECHNICAL LIBRARY

25 AEC DIVISION OF PEACEFUL NUCLEAR EXPLOSIVES

AEC LIBRARY, WASHINGTON

AEC MISSION TO THE IAEA

AEC NEVADA OPERATIONS OFFICE

AEC NEW YORK OPERATIONS OFFICE

AEC PATENT OFFICE

AEC SAN FRANCISCO OPERATIONS OFFICE

AEC SAVANNAH RIVER OPERATIONS OFFICE

AEC SCIENTIFIC REPRESENTATIVE, BEL GIUM

AEC SCIENTIFIC REPRESENTATIVE, ENGLAND

AEROSPACE CORPORATION, SAN BERNARDINO (AF)

AIR FORCE AERO PROPULSION LABORATORY (APE)

AIR FORCE FOREIGN TECHNOLOGY DIVISION

AIR FORCE INSTITUTE OF TECHNOLOGY

AIR FORCE SCHOOL OF AEROSPACE MEDICINE

AIR FORCE WEAPONS LABORATORY

AMES LABORATORY (AEC)

ARGONNE NATIONAL LABORATORY (AEC)

ARMY ABERDEEN PROVING GROUND

ARMY CHIEF OF ENGINEERS

ARMY ELECTRONICS COMMAND

ARMY ENGINEER NUCLEAR CRATERING GROUP

ARMY ENGINEER WATERWAYS EXPERIMENT

STATION

ARMY MATERIEL COMMAND

ARMY MEDICAL FIELD SERVICE SCHOOL

ARMY MEDICAL RESEARCH UNIT

ARMY MOBILITY EOUIPMENT RESEARCH AND DEVELOPMENT CENTER

ARMY OFFICE, CHIEF OF ENGINEERS

ARMY PICATINNY ARSENAL

ARMY ROCKY MOUNTAIN ARSENAL

ARMY SURGEON GENERAL

ARMY WALTER REED MEDICAL CENTER

ATOMIC POWER DEVELOPMENT ASSOCIATES, INC. (AEC)

ATOMICS INTERNATIONAL (AEC)

BABCOCK AND WILCOX COMPANY, ALLIANCE (AEC)

BATTELLE MEMORIAL INSTITUTE (AEC)

BATTELLE-NORTHWEST (AEC)

BROOKHAVEN NATIONAL LABORATORY (AEC)

BUREAU OF MINES, BARTLESVILLE (INT)

BUREAU OF MINES, DENVER (INT)

BUREAU OF MINES, LARAMIE (INT)

BUREAU OF RECLAMATION (INT)

DEPARTMENT OF AGRICULTURE NATIONAL LIBRARY

DOD DASA LIVERMORE

DOD DASA RADIOBIOLOGY RESEARCH INSTITUTE

DOD DASA SANDIA

DOD DASA WASHINGTON

DU PONT COMPANY, AIKEN (AEC)

DU PONT COMPANY, WILMINGTON (AEC)

EG\&G, INC., AL BUQUER QUE (AEC)

EG\&G INC. LAS VEGAS (AEC)

EL PASO NATURAL GAS COMPANY (AEC)

ENVIRONMENTAL RESEARCH CORPORATION (AEC)

ENVIRONMENTAL RESEARCH CORPORATION,

LAS VEGAS (AEC)

ENYIRONMENTAL SCIENCE SERVICES

ADMINISTRATION, LAS VEGAS (COMM.)

ENVIRONMENTAL SCIENCE SERVICE

ADMINISTRATION, MARYLAND (COMM.)

FRANKFORD ARSENAL (P-D LABS.)

GENERAL DYNAMICS/FORT WORTH (AF)
No. Copies

GENERAL ELECTRIC COMPANY, CINCINNATI (AEC)

GENERAL ELECTRIC COMPANY, SAN JOSE (AEC)

GEOLOGICAL SURVEY, DENVER (INT)

GEOLOGICAL SURVEY, FLAGSTAFF (INT)

GEOLOGICAL SURVEY, MENLO PARK (INT)

GEOLOGICAL SURYEY (PECORA) (INT)

GULF GENERAL ATOMIC INCORPORATED (AEC)

HOLMES AND NARVER, INC. (AEC)

HUGHES AIRCRAFT COMPANY, FULLERTON (ARMY)

INSTITUTE FOR DEFENSE ANALYSIS (ARMY)

ISOTOPES, INC. (AEC)

JET PROPULSION LABORATORY (NASA)

JOHN A. BLUME AND ASSOCIATES (AEC)

LAWRENCE RADIATION LABORATORY, BERKELEY (AEC)

LAWRENCE RADIATION LABORATORY, LIVERMORE (AEC)

LIBRARY OF CONGRESS

LOS ALAMOS SCIENTIFIC LABORATORY (AEC)

LOVELACE FOUNDATION (AEC)

MASON AND HANGER-SILAS MASON CO., INC.

AMARILLO (AEC)

MATHEMATICA (AEC)

MUESER, RUTLEDGE, WENTWORTH AND JOHNSTON (AEC) MUTUAL ATOMIC ENERGY LIABILITY UNDERWRITERS (AEC)

NASA JOHN F. KENNEDY SPACE CENTER

NATIONAL BUREAU OF STANDARDS

NATIONAL INSTITUTES OF HEALTH (HEW)

NATIONAL REACTOR TESTING STATION (INC) (AEC)

NAVY ATOMIC ENERGY DIVISION

NAVY OFFICE OF NAVAL RESEARCH (CODE 422)

NAYY ORDNANCE LABORATORY

NAVY ORDNANCE SYSTEMS COMMAND

NAVY POSTGRADUATE SCHOOL

NAVY RADIOLOGICAL DEFENSE LABORATORY

NAYY SHIP SYSTEMS COMMAND HEADQUARTERS

NRA, INC. (DASA)

OAK RIDGE NATIONAL LABORATORY (AEC)

OHIO STATE UNIVERSITY (OCD)

PENNSYLVANIA STATE UNIVERSITY (AEC)

PUBLIC HEALTH SERVICE, LAS VEGAS (HEW)

PUBLIC HEALTH SERVICE, MONTGOMERY (HEW)

PUBLIC HEALTH SERVICE, ROCKVILLE (HEW)

PUBLIC HEALTH SERVICE, WINCHESTER (HEW)

PUERTO RICO NUCLEAR CENTER (AEC)

PURDUE UNIVERSITY (AEC)

RADIOPTICS, INC. (AEC)

REYNOLDS ELECTRICAL AND ENGINEERING

COMPANY, INC. (AEC)

SANDIA CORPORATION, ALBUQUERQUE (AEC)

SANDIA CORPORATION, LIVERMORE (AEC)

SOUTHWEST RESEARCH INSTITUTE (AEC)

STANFORD UNIVERSITY (AEC)

UNION CARBIDE CORPORATION (ORGDP) (AEC)

UNIVERSITY OF CALIFORNIA, DAVIS, TALLEY (AEC)

UNIVERSITY OF CALIFORNIA, LOS ANGELES (AEC)

UNIVERSITY OF MICHIGAN (VESIAC) (ARMY)

UNIVERSITY OF ROCHESTER (KAPLON) (AEC)

UNIVERSITY OF TENNESSEE (AEC)

UNIVERSITY OF WASHINGTON (AEC)

WASHINGTON STATE UNIVERSITY (AEC)

WESTINGHOUSE ELECTRIC CORPORATION, (WAL) (AEC)

AEC DIVISION OF TECHNICAL INFORMATION EXTENSION

CLEARINGHOUSE FOR FEDERAL SCIENTIFIC

AND TECHNICAL INFORMATION 
